$$
\begin{gathered}
\text { Supporting Information } \\
\text { "A Catalytic Intermolecular Formal Ene Reaction Between Ketone-Derived Silyl } \\
\text { Enol Ethers and Alkynes" } \\
\text { Stephen D. Holmbo, Nicole A. Godfrey, Joshua J. Hirner, Sergey V. Pronin } \\
\text { Department of Chemistry, University of California } \\
\text { Irvine, California 92697-2025, United States }
\end{gathered}
$$

\title{
Contents:
}

Materials and methods

Page SI-2

Evaluation of reaction conditions

Page SI-3

Observation of ketone 3 and deuterated ketone 34

Page SI-4

Observation of siloxydiene 36 upon addition of ketone 35

Page SI-5

Preparation of deuterated standards

Page SI-6

Characterization of allene by-products

Page SI-8

General procedure for the alkenylation of silyl enol ethers

Page SI-9

Synthesis of ketone 9

Page SI-10

Preparation of ketone 35

Page SI-11

Alkenylation reactions

Page SI-13

Preparation of starting materials

Page SI-35

Comments on selectivity toward fully substituted enoxysilanes

Page SI-53

and its origins

References

Page SI-54

Spectra

Page SI-55 
Materials and methods. All reactions were carried out in flame-dried glassware under positive pressure of dry nitrogen unless otherwise noted. Reaction solvents including tetrahydrofuran (THF, Fisher, HPLC Grade), dichloromethane (DCM, Fisher, HPLC Grade), and toluene (Fisher, HPLC Grade) were dried by percolation through a column packed with neutral alumina and a column packed with a supported copper catalyst for scavenging oxygen (Q5) under positive pressure of argon. Anhydrous 1,2-dichloroethane (Fisher, ACS Grade) and anhydrous triethylamine (Oakwood Chemical) were distilled from calcium hydride $(10 \% \mathrm{w} / \mathrm{v})$ under positive pressure of nitrogen. Anhydrous hexamethylphosphoramide (HMPA, Oakwood Chemical) was distilled from calcium hydride (10\% w/v) under vacuum (ca. 0.1 torr). Solvents for extraction, thin layer chromatography (TLC), and flash column chromatography were purchased from Fischer (ACS Grade) and VWR (ACS Grade) and used without further purification. Chloroform-d and benzene- $d_{6}$ for ${ }^{1} \mathrm{H}$ and ${ }^{13} \mathrm{C}$ NMR analysis were purchased from Cambridge Isotope Laboratories and used without further purification. Commercially available reagents were used without further purification unless otherwise noted. Reactions were monitored by thin layer chromatography (TLC) using precoated silica gel plates (EMD Chemicals, Silica gel $60 \mathrm{~F}_{254}$ ). Flash column chromatography was performed over silica gel (Acros Organics, $60 \AA$, particle size $0.04-0.063 \mathrm{~mm}$ ). ${ }^{1} \mathrm{H}$ NMR and ${ }^{13} \mathrm{C}$ NMR spectra were recorded on Bruker DRX-500 (BBO probe), Bruker DRX-500 (TCI cryoprobe), Bruker AVANCE600 (TBI probe), and Bruker AVANCE600 (BBFO cryoprobe) spectrometers using residual solvent peaks as internal standards $\left(\mathrm{CHCl}_{3} @ 7.26\right.$ ppm ${ }^{1} \mathrm{H}$ NMR, 77.00 ppm ${ }^{13} \mathrm{C}$ NMR; $\mathrm{C}_{6} \mathrm{H}_{6} @ 7.16$ ppm ${ }^{1} \mathrm{H}$ NMR, 128.00 ppm ${ }^{13} \mathrm{C}$ NMR). High-resolution mass spectra (HRMS) were recorded on Waters LCT Premier TOF spectrometer with ESI and $\mathrm{Cl}$ sources. 


\section{Evaluation of reaction conditions:}

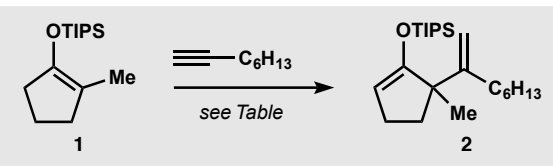

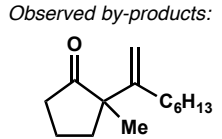

3

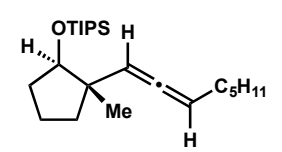

4 (mix. of diastereomers)

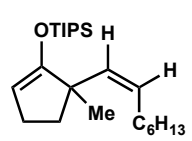

\begin{tabular}{|c|c|}
\hline $\begin{array}{l}\text { Conditions }(0.25-0.5 \mathrm{mmol} \text { of } 1,1.5 \text { equiv. of alkyne, } \\
0.25-0.5 \mathrm{~mL} \text { of }\left(\mathrm{CH}_{2} \mathrm{Cl}\right)_{2}, 20-28 \mathrm{~h} \text {; unless otherwise } \\
\text { noted) }\end{array}$ & Comments \\
\hline $5 \mathrm{~mol} \%\left(\mathrm{Ph}_{3} \mathrm{P}\right) \mathrm{AuCl}, 5 \mathrm{~mol} \% \mathrm{AgOTf}, 65^{\circ} \mathrm{C}$ & $\begin{array}{l}\text { No reaction. } \\
\text { (JackiePhos)AuCl was equally inefficient. }\end{array}$ \\
\hline $5 \mathrm{~mol} \% \mathrm{IPrAuCl}, 5 \mathrm{~mol} \% \mathrm{AgOTf}, 65^{\circ} \mathrm{C}$ & $\begin{array}{l}2:<1 \% ; 3: 1 \% ; 4:<1 \% ; \mathbf{5}: 2 \% \\
\mathrm{AgO}_{2} \mathrm{CCF}_{3} \text { additive also performed poorly. }\end{array}$ \\
\hline $5 \mathrm{~mol} \%$ IPrAuCl, $5 \mathrm{~mol} \% \mathrm{NaBArF}, 65^{\circ} \mathrm{C}$ & $\begin{array}{l}\text { 2: } 11 \% ; \mathbf{3}: 8 \% ; \mathbf{4}: 10 \% ; \mathbf{5}:<1 \% . \\
\text { This entry represented the best performing } \\
\mathrm{Au}(\mathrm{I}) \text {-based catalytic system. }\end{array}$ \\
\hline $5 \mathrm{~mol} \% \ln (\mathrm{OTf})_{3}$, neat, $120^{\circ} \mathrm{C}$ & Partial conversion, no desired products. \\
\hline $5 \mathrm{~mol} \% \ln (\mathrm{OTf})_{3}, 65^{\circ} \mathrm{C}$ & 2: $<1 \% ; \mathbf{3}: 1 \% ; \mathbf{4}:<1 \% ; \mathbf{5}:<1 \%$. \\
\hline $5 \mathrm{~mol} \% \operatorname{lnCl}{ }_{3}, 65^{\circ} \mathrm{C}$ & 2: 5\%; 3: 9\%; 4: <1\%; 5: <1\%. \\
\hline $5 \mathrm{~mol} \% \operatorname{lnBr} 3,65^{\circ} \mathrm{C}$ & $\begin{array}{l}\text { 2: } 72 \% ; 3: 5 \% ; 4: 6 \% ; 5: 2 \% . \\
\operatorname{lnBr}_{3} \text { was the best performing catalyst for } \\
\text { alkenylation of ketone-derived enoxysilanes }\end{array}$ \\
\hline $5 \mathrm{~mol} \% \ln (\mathrm{OTf})_{3}, 5 \mathrm{~mol} \% \mathrm{LiBr}, 65^{\circ} \mathrm{C}$ & 2: $1 \% ; \mathbf{3 :} 2 \% ; \mathbf{4 :}<1 \% ; \mathbf{5}:<1 \%$. \\
\hline $5 \mathrm{~mol} \% \ln (\mathrm{OTf})_{3}, 10 \mathrm{~mol} \% \mathrm{LiBr}, 65^{\circ} \mathrm{C}$ & 2: 5\%; 3: 8\%; 4: <1\%; 5: <1\%. \\
\hline $5 \mathrm{~mol} \% \ln (\mathrm{OTf})_{3}, 5 \mathrm{~mol} \%(\mathrm{Me})_{4} \mathrm{NBr}, 65^{\circ} \mathrm{C}$ & 2: $1 \% ; \mathbf{3}: 2 \% ; \mathbf{4}:<1 \% ; \mathbf{5}:<1 \%$. \\
\hline $5 \mathrm{~mol} \% \ln (\mathrm{OTf})_{3}, 10 \mathrm{~mol} \%(\mathrm{Me})_{4} \mathrm{NBr}, 65^{\circ} \mathrm{C}$ & $\begin{array}{l}\text { 2: } 4 \% ; 3: 5 \% ; \mathbf{4}:<1 \% ; 5:<1 \% \text {. } \\
\text { These increases in the reactivity of } \ln (\mathrm{OTf})_{3} \text { are } \\
\text { possibly due to generation of } \operatorname{InBr}_{3} \text {. }\end{array}$ \\
\hline $5 \mathrm{~mol} \% \operatorname{lnl} 3,65^{\circ} \mathrm{C}$ & 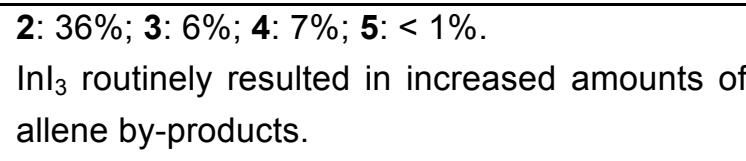 \\
\hline $5 \mathrm{~mol} \% \operatorname{lnBr}{ }_{3}, 5 \mathrm{~mol} \% \mathrm{NaBArF}, 65^{\circ} \mathrm{C}$ & $\begin{array}{l}\text { 2: } 40 \% ; 3: 11 \% ; \mathbf{4}: 3 \% ; \mathbf{5}:<1 \% . \\
\text { Other halide-scavenging additives performed } \\
\text { poorly }\left(\mathrm{AgOTf}_{\mathrm{AgBF}}\right) .\end{array}$ \\
\hline $5 \mathrm{~mol} \% \operatorname{lnBr} 3, \mathrm{PhMe}, 75^{\circ} \mathrm{C}$ & ca. $10 \%$ of 2 \\
\hline $5 \mathrm{~mol} \% \mathrm{MeOH}, 8 \mathrm{~mol} \% \mathrm{TMSBr}, 65^{\circ} \mathrm{C}$ & No reaction. $\mathrm{HBr}$ is generated in situ. \\
\hline $5 \mathrm{~mol} \% \mathrm{TfOH}, 65^{\circ} \mathrm{C}$ & No reaction. \\
\hline $5 \mathrm{~mol} \% \operatorname{lnBr}_{3}, 5 \mathrm{~mol} \% \mathrm{MeOH}, 8 \mathrm{~mol} \% \mathrm{TMSBr}, 65^{\circ} \mathrm{C}$ & 2: 51\%; 3: 10\%; 4: 9\%; 5: 2\%. \\
\hline $10 \mathrm{~mol} \% \mathrm{ZnBr}_{2}, 65^{\circ} \mathrm{C}$ & 2: 4\%; 3: 5\%; 4: 1\%; 5: <1\%. \\
\hline
\end{tabular}


Observation of ketone 3 and deuterated ketone 34:

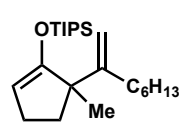

2

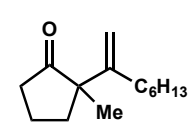

3

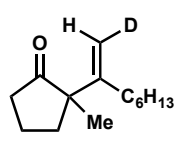

34

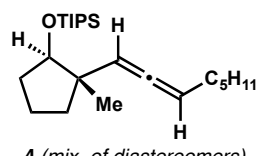

4 (mix. of diastereomers)
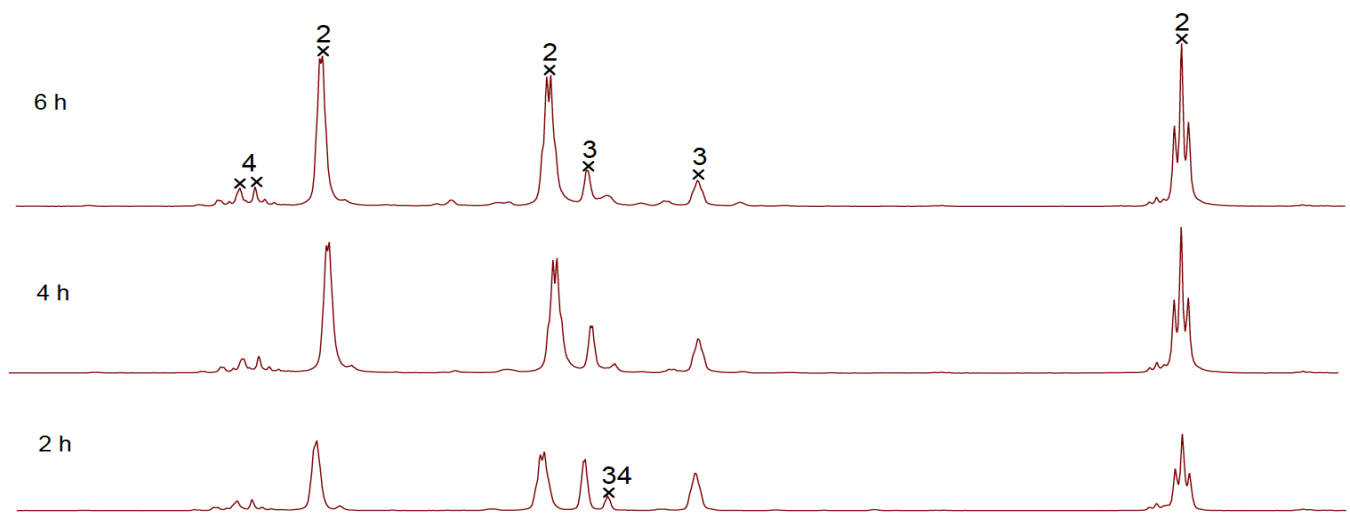

$1 \mathrm{~h}$
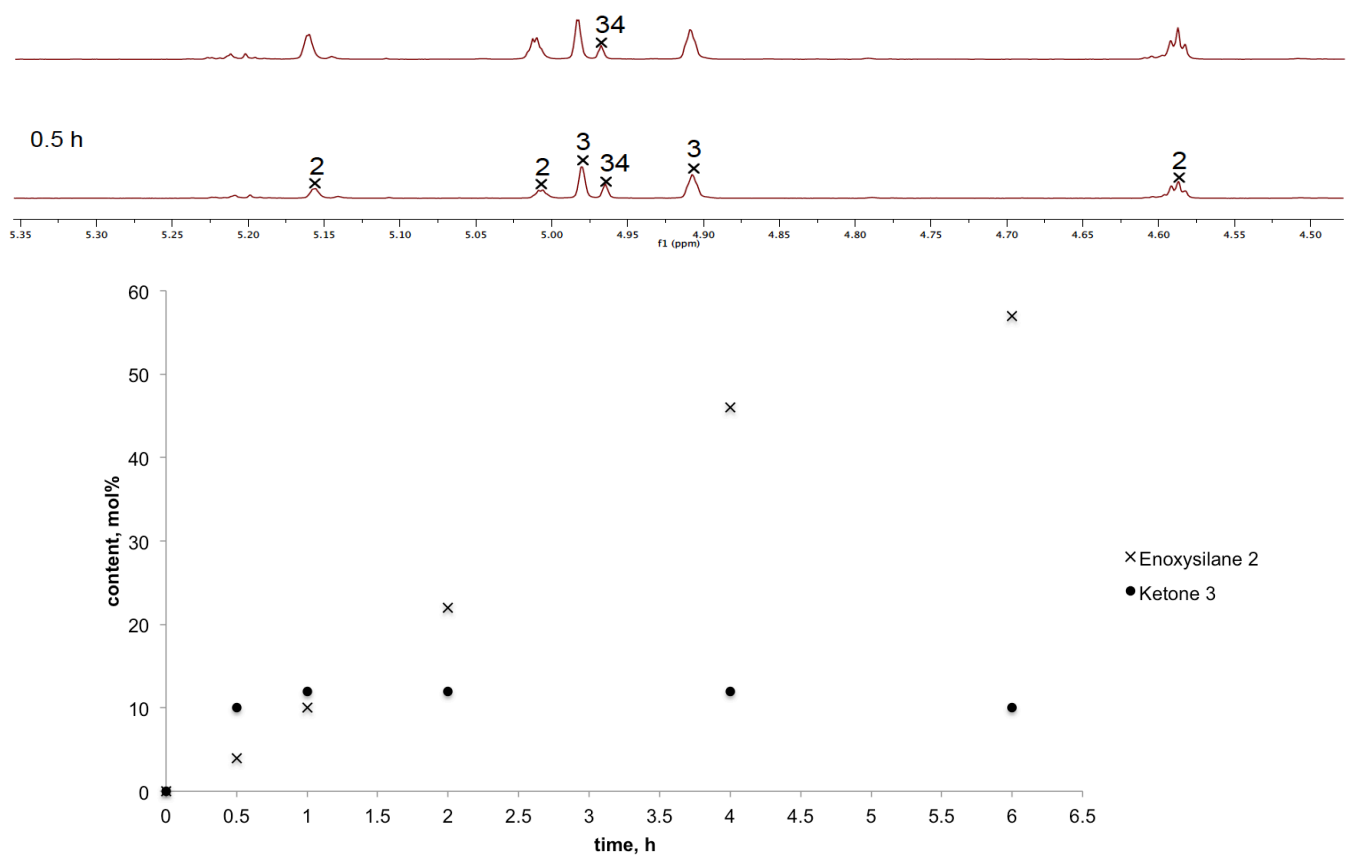

The reaction between silyl enol ether 1 (residual TIPSOH was rigorously removed by distillation) and 1octyne in the presence of $10 \mathrm{~mol} \%$ of $\operatorname{InBr}_{3}$ and an internal standard (4,4'-di-tert-butylbiphenyl) was set up according to the general procedure (see below) and heated to $65{ }^{\circ} \mathrm{C}$. Aliquots were taken at various time points and treated with an anhydrous solution of $\mathrm{Et}_{3} \mathrm{~N}$ and $\mathrm{CD}_{3} \mathrm{OD}$ in $\left(\mathrm{CH}_{2} \mathrm{Cl}\right)_{2}$ for 5 min. The crude samples were analyzed by ${ }^{1} \mathrm{H}$ NMR. Content of ketone 3 increased rapidly and remained constant (ca. 10 mol\%) during the reaction. Addition of TIPSOH at the beginning of the reaction resulted in proportional increase in the content of ketone $\mathbf{3}$, shorter reaction times, but lower yields of the desired product. 


\section{Observation of siloxydiene 36 upon addition of ketone 35 :}

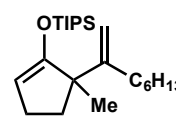

2

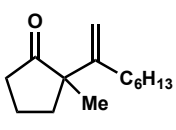

3

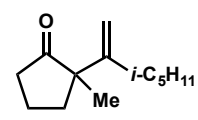

35

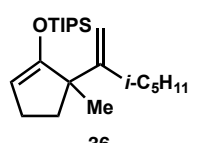

36
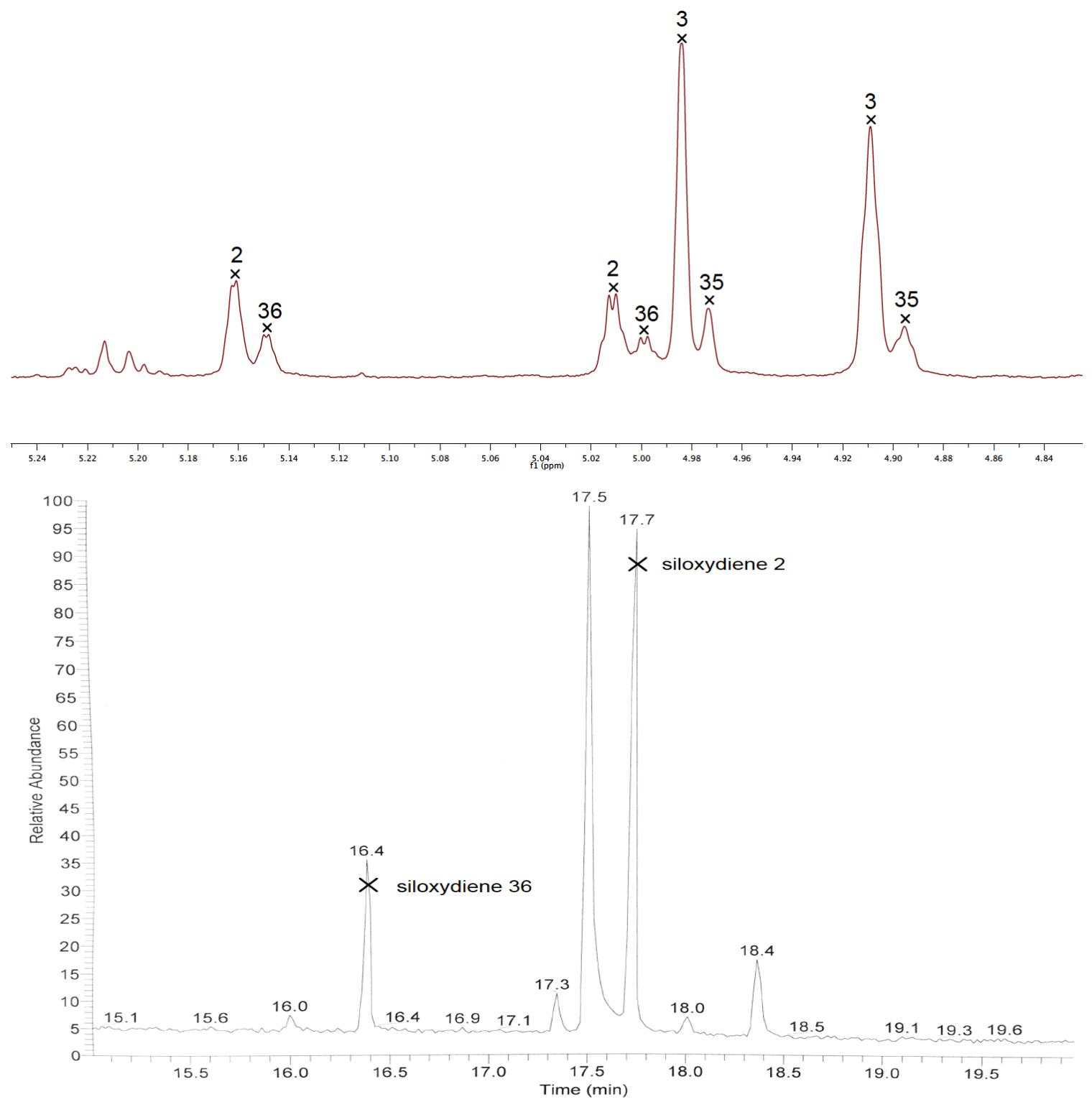

The reaction between silyl enol ether 1 and 1-octyne in the presence of $10 \mathrm{~mol} \%$ of $\operatorname{InBr}_{3}$ and $7 \mathrm{~mol} \%$ of ketone 35 was set up according to the general procedure (see below) and heated to $65{ }^{\circ} \mathrm{C}$. An aliquot was taken after $1 \mathrm{~h}$ and treated with an anhydrous solution of $\mathrm{Et}_{3} \mathrm{~N}$ and $\mathrm{MeOH}$ in $\left(\mathrm{CH}_{2} \mathrm{Cl}\right)_{2}$ for $5 \mathrm{~min}$. The crude sample was analyzed by ${ }^{1} \mathrm{H}$ NMR and GC/MSD. Conversion of ketone $\mathbf{3 5}$ to siloxydiene $\mathbf{3 6}$ was ca. $40 \%$. Note: in this experiment the observed amount of ketone 3 in the crude sample corresponds to the sum of the amounts of ketone 3 and alkenylindium 31 (or related species) in the reaction. 


\section{Preparation of deuterated standards}

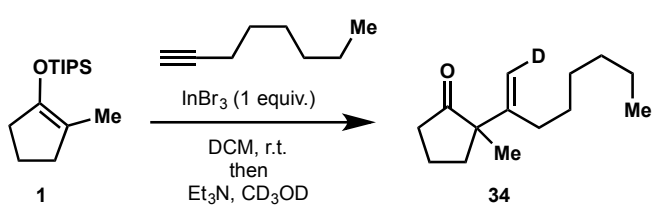

Ketone 34. Silyl enol ether $1(0.14 \mathrm{~mL}, 0.50 \mathrm{mmol}), \operatorname{lnBr}_{3}(177 \mathrm{mg}, 0.50 \mathrm{mmol}), 1$-octyne $(0.11 \mathrm{~mL}, 0.75$ mmol), and anhydrous $\mathrm{CH}_{2} \mathrm{Cl}_{2}(0.5 \mathrm{~mL})$ were combined under the atmosphere of nitrogen. The resulting mixture was stirred at room temperature for $24 \mathrm{~h}$, and then quenched with $\mathrm{Et}_{3} \mathrm{~N}(0.2 \mathrm{~mL})$ followed by addition of $\mathrm{CD}_{3} \mathrm{OD}(1 \mathrm{~mL})$. The mixture was poured into saturated aqueous $\mathrm{NaHCO}_{3}$, extracted with hexanes, washed with brine, dried over anhydrous sodium sulfate, and concentrated under reduced pressure. Isolation by flash chromatography (0-5\% EtOAc in hexanes) afforded $65 \mathrm{mg}(62 \%, 0.31 \mathrm{mmol})$ of ketone 34 as a yellow oil (81\% deuterium incorporation). Observation of NOE between the deuterated alkene and the methyl group at the quaternary center as well as the absence of NOE between the deuterated alkene and the allylic methylene group confirmed the relative stereochemistry of deuteration.

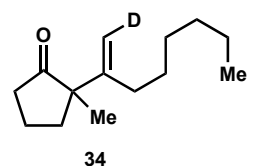

Ketone 34

${ }^{1} \mathrm{H}$ NMR $\left(500 \mathrm{MHz}, \mathrm{CDCl}_{3}\right)$ :

$\delta 4.84(\mathrm{t}, \mathrm{J}=0.8 \mathrm{~Hz}, 1 \mathrm{H})$

2.32-2.18 (m, 3H)

1.99-1.93 (m, 2H)

${ }^{13} \mathrm{C}$ NMR $\left(125 \mathrm{MHz}, \mathrm{CDCl}_{3}\right)$ :
37.8

36.4

32.0

31.7
1.88-1.82 (m, 2H)

$1.66(\mathrm{dt}, \mathrm{J}=13.1,7.4 \mathrm{~Hz}, 1 \mathrm{H})$

1.47-1.39 (m, 2H) $1.32-1.28(\mathrm{~m}, 6 \mathrm{H})$

$1.15(\mathrm{~s}, 3 \mathrm{H})$

$0.88(\mathrm{t}, \mathrm{J}=6.9 \mathrm{~Hz}, 3 \mathrm{H})$

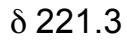

149.6

$110.2(\mathrm{t}, \mathrm{J}=23.8 \mathrm{~Hz})$

55.2
29.4

28.7

22.8

21.9

HRMS (ESI) $\mathrm{m} / \mathrm{z}$ calculated for $\mathrm{C}_{14} \mathrm{H}_{23} \mathrm{DONa}[\mathrm{M}+\mathrm{Na}]^{+}: 232.1788$, found: 232.1782

TLC: $R f=0.35(10 \% \mathrm{v} / \mathrm{v}$ ethyl acetate in hexanes $)$ 


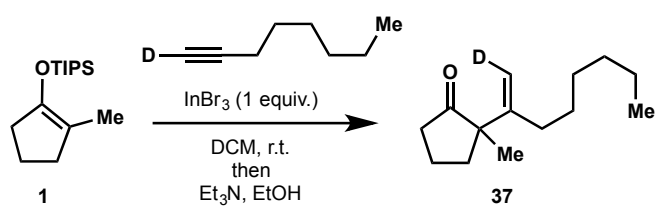

Ketone 37. This compound was prepared in order to compare with ketone 36 . Silyl enol ether $1(0.14 \mathrm{~mL}$, $0.50 \mathrm{mmol}), \operatorname{lnBr}_{3}$ (177 mg, $\left.0.50 \mathrm{mmol}\right), 1$-octyne- $\mathrm{d}_{1}$ (>95\% deuterium incorporation, $0.11 \mathrm{~mL}, 0.75$ mmol), ${ }^{1}$ and anhydrous $\mathrm{CH}_{2} \mathrm{Cl}_{2}(0.5 \mathrm{~mL})$ were combined under the atmosphere of nitrogen. The resulting mixture was stirred at room temperature for $22 \mathrm{~h}$, and then quenched with $\mathrm{Et}_{3} \mathrm{~N}(0.2 \mathrm{~mL})$ followed by addition of EtOH $(1 \mathrm{~mL})$. The mixture was poured into saturated aqueous $\mathrm{NaHCO}_{3}$, extracted with hexanes, washed with brine, dried over anhydrous sodium sulfate, and concentrated under reduced pressure. Isolation by flash chromatography (0-5\% EtOAc in hexanes) afforded $76 \mathrm{mg}(73 \%, 0.36 \mathrm{mmol})$ of ketone 37 as a yellow oil (94\% deuterium incorporation). Observation of NOE between the deuterated alkene and the allylic methylene group as well as the absence of NOE between the deuterated alkene and the methyl group at the quaternary center confirmed the relative stereochemistry of deuteration.

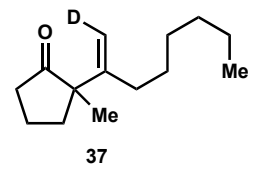

\section{Ketone 37}

${ }^{1} \mathrm{H}$ NMR $\left(500 \mathrm{MHz}, \mathrm{CDCl}_{3}\right)$ :

$\delta 4.90(\mathrm{t}, \mathrm{J}=1.5 \mathrm{~Hz}, 1 \mathrm{H})$

1.89-1.82 (m, 2H)

2.32-2.20 (m, 3H)

1.99-1.93 (m, 2H)

$1.66(\mathrm{dt}, \mathrm{J}=13.1,7.4 \mathrm{~Hz}, 1 \mathrm{H})$

1.46-1.41 (m, 2H)

${ }^{13} \mathrm{C} \mathrm{NMR}\left(125 \mathrm{MHz}, \mathrm{CDCl}_{3}\right)$ :

б 221.4

37.8

36.4

32.0

31.8
149.6

$110.2(\mathrm{t}, \mathrm{J}=23.8 \mathrm{~Hz})$
29.4

28.7

22.8

21.9 $1.32-1.28(\mathrm{~m}, 6 \mathrm{H})$

$1.15(\mathrm{~s}, 3 \mathrm{H})$

$0.88(\mathrm{t}, \mathrm{J}=6.9 \mathrm{~Hz}, 3 \mathrm{H})$

HRMS (ESI) $\mathrm{m} / \mathrm{z}$ calculated for $\mathrm{C}_{15} \mathrm{H}_{26} \mathrm{O}[\mathrm{M}]^{+}: 232.1788$, found: 232.1785

TLC: $\mathrm{Rf}=0.35(10 \% \mathrm{v} / \mathrm{v}$ ethyl acetate in hexanes $)$ 


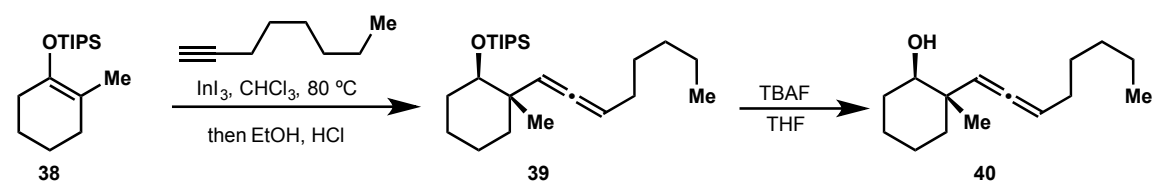

Characterization of allene by-products. Alkenylation of enoxysilane 38 produced more allene byproducts than alkenylation of enoxysilane 1, and therefore was chosen for the purposes of characterization. Alkenylation of enoxysilane $\mathbf{3 8}$ was performed according to "General procedure for the alkenylation of silyl enol ethers" (see below) from silyl enol ether $\mathbf{3 8}$ (ratio of tetra- and trisubstituted isomers >10:1) and 1-octyne using $\operatorname{lnl}_{3}$ instead of $\operatorname{InBr}_{3}$. The reaction was performed in solution on a 0.5 mmol scale with 0.1 equiv of $\mathrm{Inl}_{3}$. The reaction mixture was heated to $80{ }^{\circ} \mathrm{C}$ for $24 \mathrm{~h}$. An inseparable mixture of allene 39 and the expected silyl enol ether was produced. The crude mixture was treated with $1 \mathrm{~mL} \mathrm{EtOH}$ and $0.2 \mathrm{~mL}$ of aqueous $\mathrm{HCl}(6 \mathrm{M})$ to hydrolyze the silyl enol ether. The resulting solution was stirred vigorously for $45 \mathrm{~min}$ to ensure complete hydrolysis. The reaction mixture was diluted with saturated aqueous $\mathrm{NaHCO}_{3}$, extracted with hexanes and washed with brine. Isolation by flash chromatography (elution with hexanes) afforded $96 \mathrm{mg}$ of allene 39 contaminated with an unknown impurity. This mixture was treated with an excess of TBAF in THF $(1 \mathrm{~mL})$ and stirred at room temperature for $16 \mathrm{~h}$. The reaction mixture was diluted with $\mathrm{Et}_{2} \mathrm{O}$, washed with saturated aqueous $\mathrm{NaHCO}_{3}$ and brine, dried over anhydrous sodium sulfate, and concentrated under reduced pressure. Purification by flash chromatography (elution with 10\% $\mathrm{Et}_{2} \mathrm{O}$ in hexanes) afforded $22 \mathrm{mg}(20 \%, 0.10 \mathrm{mmol}$ ) of allene 40 (ca. 1:1 mixture of diastereomeric allenes) as a colorless oil.

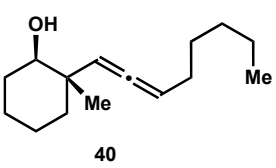

\section{Allene 40}

${ }^{1} \mathrm{H}$ NMR $\left(500 \mathrm{MHz}, \mathrm{CDCl}_{3}\right)$ :

\begin{tabular}{|c|c|c|c|c|}
\hline$\delta 5.27-5.18(\mathrm{~m}, 1 \mathrm{H})$ & & $1.80-1.69(\mathrm{~m}, 3 \mathrm{H})$ & & $1.00(\mathrm{~s}, 3 \mathrm{H})$ \\
\hline $5.05-5.01(\mathrm{~m}, 1 \mathrm{H})$ & & $1.55-1.51(\mathrm{~m}, 1 \mathrm{H})$ & & $0.89(\mathrm{t}, \mathrm{J}=7.1 \mathrm{~Hz}, 3 \mathrm{H})$ \\
\hline $3.47-3.40(\mathrm{~m}, 1 \mathrm{H})$ & & $1.48-1.38(\mathrm{~m}, 4 \mathrm{H})$ & & \\
\hline $2.05-1.95(\mathrm{~m}, 2 \mathrm{H})$ & & $1.35-1.26(\mathrm{~m}, 6 \mathrm{H})$ & & \\
\hline \multicolumn{5}{|c|}{${ }^{13} \mathrm{C} \mathrm{NMR}\left(125 \mathrm{MHz}, \mathrm{CDCl}_{3}\right)$} \\
\hline$\delta 202.6$ & 75.5 & & 29.34 & 24.4 \\
\hline 202.3 & 40.7 & & 29.29 & 22.6 \\
\hline 101.0 & 40.6 & & 29.23 & 21.5 \\
\hline 93.7 & 37.5 & & 29.19 & 14.2 \\
\hline 93.6 & 37.4 & & 29.1 & \\
\hline 75.7 & 31.5 & & 29.0 & \\
\hline
\end{tabular}

HRMS (Cl) $\mathrm{m} / \mathrm{z}$ calculated for $\mathrm{C}_{15} \mathrm{H}_{26} \mathrm{O}[\mathrm{M}]^{+}: 222.1984$, found: 222.1989

IR (thin film) 3417, 2931, 2865, 1959, $1465 \mathrm{~cm}^{-1}$

TLC: $R f=0.3(10 \% \mathrm{v} / \mathrm{v}$ ethyl acetate in hexanes $)$ 


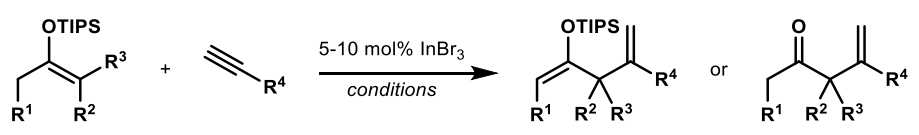

General procedure for the alkenylation of silyl enol ethers. Reactions in solution. In a glovebox under pressure of nitrogen, a $5 \mathrm{~mL}$ Schlenk flask was charged with $\operatorname{lnBr}_{3}$ (0.05-0.10 equiv). The flask was sealed with a plastic cap, removed from the glovebox, and connected to a double bank vacuum manifold. The plastic cap was replaced with a rubber septum under continuous flow of nitrogen. Anhydrous 1,2dichloroethane (1 $\mathrm{M}$ in substrate), the silyl enol ether (1.0 equiv), and alkyne (1.5 equiv) were added. Under flow of nitrogen, the septum was replaced with a yellow cap, which was secured with Parafilm. The nitrogen inlet for the Schlenk flask was closed and the reaction was heated to $50-80{ }^{\circ} \mathrm{C}$ for $23-72 \mathrm{~h}$.

Reactions in the absence of solvent. A $4 \mathrm{~mL}$ vial was charged with the silyl enol ether (1.0 equiv) and alkyne (1.5 equiv). The reagents were degassed with a flow of nitrogen for $10 \mathrm{~min}$ and transferred to a gloxebox. The reaction vial was charged with $\operatorname{lnBr}_{3}$ (0.05-0.10 equiv) and sealed with a Teflon-lined plastic screw-cap, which was secured with electrical tape. The vial was removed from the glovebox and heated to $50-80{ }^{\circ} \mathrm{C}$ for $24-72 \mathrm{~h}$.

Isolation of 2-siloxy-1,4-dienes. The reaction was quenched with anhydrous $\mathrm{Et}_{3} \mathrm{~N}(0.5 \mathrm{~mL})$, then anhydrous $\mathrm{EtOH}(1 \mathrm{~mL})$ was added and the reaction was stirred for $20 \mathrm{~min}$ at room temperature. Purification by flash chromatography on $\mathrm{Et}_{3} \mathrm{~N}$-treated silica gel yielded the desired 2-siloxy-1,4-dienes (Note 1).

Isolation of $\beta, \gamma$-unsaturated ketones. The reaction was quenched with anhydrous EtOH $(1 \mathrm{~mL})$ and stirred until TLC analysis indicated complete hydrolysis of siloxydienes (Note 2). The reaction was diluted with hexanes, washed with saturated aqueous $\mathrm{NaHCO}_{3}$ and brine, dried over anhydrous sodium sulfate, and concentrated under reduced pressure. Purification by flash chromatography yielded the desired $\beta, \gamma-$ unsaturated ketones (Note 3).

Note 1: All 2-siloxy-1,4-dienes derived from alkylacetylenes contained small admixture of corresponding allenes (ca. $5 \mathrm{~mol} \%$; see discussion in the manuscript), inseparable from the desired products. 2-Siloxy1,4-dienes were obtained as mixtures of regioisomers with varying ratios (see entries below or Table 2 in the manuscript). The ratios were identified based on integration of alkenes in ${ }^{1} \mathrm{H}$ NMR spectra.

Note 2: In some cases, addition of small amounts of aqueous $\mathrm{HCl}$ was necessary.

Note 3: $\beta, \gamma$-Unsaturated ketones were obtained as mixtures of regioisomers with varying ratios (see entries below or Table 2 in the manuscript). The ratios were identified based on integration of alkenes in ${ }^{1} \mathrm{H}$ NMR spectra. 


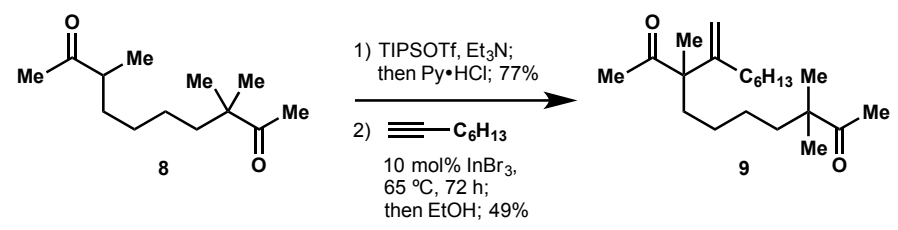

Synthesis of diketone 9. TIPSOTf $(1.5 \mathrm{~mL}, 5.6 \mathrm{mmol})$ was added to a solution of diketone 8 (596 $\mathrm{mg}$, $2.8 \mathrm{mmol})$ in DCM $(8 \mathrm{~mL})$. Triethylamine $(1 \mathrm{~mL}, 7.3 \mathrm{mmol})$ was added over 2 minutes. The reaction was stirred at room temperature for $3 \mathrm{~h}$, then diluted in hexanes, washed with saturated aqueous $\mathrm{NaHCO}_{3}$ and brine, dried over anhydrous sodium sulfate, and concentrated under reduced pressure to yield exclusively product containing two monosubstituted siloxyalkenes. The crude material was dissolved in DCM (6 $\mathrm{mL})$ and added to a Schlenk flask charged with pyridine hydrochloride (16 mg, $0.14 \mathrm{mmol})$ and stirred at room temperature for $1 \mathrm{~h}$. The reaction was diluted with hexanes, washed with saturated aqueous $\mathrm{NaHCO}_{3}$ and brine, dried over anhydrous sodium sulfate, and concentrated under reduced pressure. Purification through a plug of neutral alumina (elution with hexanes) afforded $1.13 \mathrm{~g}$ (77\% yield, 5:1 trisubstituted to monosubstituted silyl enol ether, and a 0.6:1 mixture of $E$ and $Z$ isomers) of silyl enol ethers as a light yellow oil. This mixture was alkenylated according to "General procedure for the alkenylation of silyl enol ethers" with 1-octyne. The reaction was performed in solution on a $0.23 \mathrm{mmol}$ scale with 0.1 equiv of $\mathrm{InBr}_{3}$. The reaction mixture was heated to $65{ }^{\circ} \mathrm{C}$ for $64 \mathrm{~h}$. The reaction was quenched with $1 \mathrm{~mL} E t O H$ and $0.2 \mathrm{~mL}$ of aqueous $\mathrm{HCl}(1 \mathrm{M})$ and the resulting solution was stirred for $30 \mathrm{~min}$. The alkenylation proceeded in $49 \%$ yield ( $36.5 \mathrm{mg}, 0.113 \mathrm{mmol}$ of diketone 9 obtained, 10:1 r.r.).

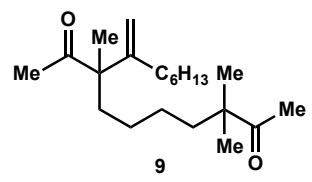

Diketone 9

${ }^{1} \mathrm{H}$ NMR $\left(500 \mathrm{MHz}, \mathrm{CDCl}_{3}\right)$ :

$\delta 5.04(\mathrm{t}, \mathrm{J}=1.42 \mathrm{~Hz}, 1 \mathrm{H})$

$1.65-1.61(\mathrm{~m}, 2 \mathrm{H})$

1.16-1.13 (m, 2H)

$5.03(\mathrm{~s}, 1 \mathrm{H})$

1.50-1.47 (m, 2H)

$1.09(\mathrm{~s}, 6 \mathrm{H})$

$2.10(\mathrm{~s}, 3 \mathrm{H})$

$1.45-1.40(\mathrm{~m}, 2 \mathrm{H})$

$0.88(\mathrm{t}, \mathrm{J}=6.9 \mathrm{~Hz}, 3 \mathrm{H})$

$2.01(2,3 \mathrm{H})$

1.33-1.24 (m, 8H)

1.83-1.74 (m, 2H)

$1.18(\mathrm{~s}, 3 \mathrm{H})$

${ }^{13} \mathrm{C}$ NMR $\left(150 \mathrm{MHz}, \mathrm{CDCl}_{3}\right)$ :

$\delta 214.1$

47.8

29.3

24.8

14.1

212.0

40.0

28.3

24.36

150.8

34.5

25.5

24.35

110.7

32.2

25.2

22.7

57.8

31.8

25.1

20.1

HRMS (Cl) calculated for $\mathrm{C}_{21} \mathrm{H}_{38} \mathrm{O}_{2} \mathrm{Na}[\mathrm{M}+\mathrm{Na}]^{+}: 345.2769$, found: 345.2770

TLC: $\mathrm{Rf}=0.35(10 \%$ EtOAc in hexanes $)$ 


\section{Preparation of ketone 35}

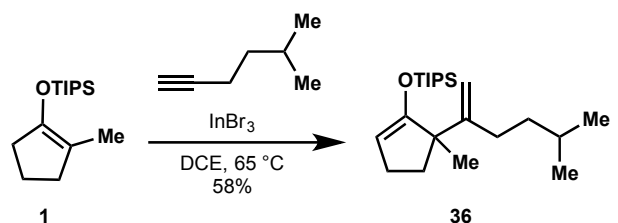

Silyl enol ether 36. Prepared according to "General procedure for the alkenylation of silyl enol ethers" from silyl enol ether $1^{4}$ (ratio of tetra- and trisubstituted isomers $\geq 10: 1$ ) and 5-methyl-1-hexyne. The reaction was performed in solution on a $0.25 \mathrm{mmol}$ scale with 0.1 equiv of $\operatorname{InBr}_{3}$. The reaction mixture was heated to $50{ }^{\circ} \mathrm{C}$ for $21 \mathrm{~h}$. The alkenylation proceeded in $58 \%$ yield $(0.15 \mathrm{mmol}, 51 \mathrm{mg}$ of silyl enol ether $36,>20: 1$ r.r.).

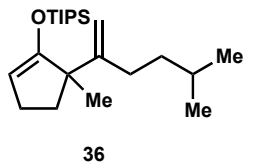

Silyl enol ether 36

${ }^{1} \mathrm{H}$ NMR $\left(500 \mathrm{MHz}, \mathrm{CDCl}_{3}\right)$ :

$\delta 4.95(\mathrm{~d}, \mathrm{~J}=1.1 \mathrm{~Hz}, 1 \mathrm{H})$

$1.63-1.57(\mathrm{~m}, 1 \mathrm{H})$

$4.83(\mathrm{~d}, \mathrm{~J}=1.4 \mathrm{~Hz}, 1 \mathrm{H})$

1.43-1.39 (m, 2H)

$4.59(\mathrm{t}, \mathrm{J}=2.3 \mathrm{~Hz}, 1 \mathrm{H})$

$1.29(\mathrm{~s}, 3 \mathrm{H})$

2.27-2.22 (m, 2H)

1.27-1.21 (m, 3H)

$2.09-2.06(\mathrm{~m}, 2 \mathrm{H})$

$1.14-1.10(\mathrm{~m}, 18 \mathrm{H})$

2.04-1.99 (m, 1H)

1.67 (ddd, J = 12.9, 7.8, $6.4 \mathrm{~Hz}, 1 \mathrm{H}$ )

${ }^{13} \mathrm{C}$ NMR (125 MHz, $\left.\mathrm{CDCl}_{3}\right)$ :

$\delta 159.2$

53.1

28.5

22.8

154.6

38.1

26.1

18.22

107.1

36.4

24.0

18.20

99.4

29.6

23.0

12.7

HRMS (ESI) calculated for $\mathrm{C}_{13} \mathrm{H}_{22} \mathrm{ONa}[\mathrm{M}+\mathrm{Na}]^{+}: 217.1568$, found: 217.1564

TLC: $R f=0.4(10 \%$ EtOAc in hexanes $)$ 


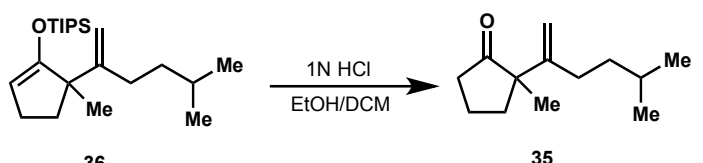

Ketone 35. Silyl enol ether $36(26.3 \mathrm{mg}, 0.075 \mathrm{mmol})$ was desilylated by treatment with $0.2 \mathrm{~mL}$ of $1 \mathrm{~N}$ $\mathrm{HCl}, 1 \mathrm{~mL}$ of EtOH, and $1 \mathrm{~mL}$ of $\mathrm{DCM}$, and stirred for $1 \mathrm{~h}$. The reaction mixture was quenched with saturated aqueous $\mathrm{NaHCO}_{3}$, extracted with hexanes, dried over anhydrous sodium sulfate, and concentrated under reduced pressure. Purification by flash chromatography (gradient elution 0-3\% EtOAc in hexanes) afforded $8.8 \mathrm{mg}(0.045 \mathrm{mmol}, 60 \%)$ ketone 35 as a colorless oil.

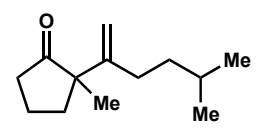

35

Ketone 35

${ }^{1} \mathrm{H}$ NMR $\left(500 \mathrm{MHz}, \mathrm{CDCl}_{3}\right)$ :

$\delta 4.91(\mathrm{t}, \mathrm{J}=1.2 \mathrm{~Hz}, 1 \mathrm{H})$

$1.67(\mathrm{dt}, \mathrm{J}=13.1,7.5 \mathrm{~Hz}, 1 \mathrm{H})$

$4.86(\mathrm{~d}, \mathrm{~J}=0.5 \mathrm{~Hz}, 1 \mathrm{H})$

$1.60-1.51(\mathrm{~m}, 1 \mathrm{H})$

2.34-2.20 (m, 3H)

1.36-1.31 (m, 2H)

1.99-1.96 (m, 2H)

$1.16(\mathrm{~s}, 3 \mathrm{H})$

1.89-1.82 (m, 2H)

$0.90(\mathrm{~d}, \mathrm{~J}=6.6 \mathrm{~Hz}, 6 \mathrm{H})$

${ }^{13} \mathrm{C}$ NMR $\left(125 \mathrm{MHz}, \mathrm{CDCl}_{3}\right)$ :

$\delta 221.2$

38.1

28.1

18.9

149.8

37.7

22.67

110.4

36.3

22.66

55.2

29.5

21.8

HRMS (ESI) calculated for $\mathrm{C}_{13} \mathrm{H}_{22} \mathrm{ONa}[\mathrm{M}+\mathrm{Na}]^{+}: 217.1568$, found: 217.1564

TLC: $\mathrm{Rf}=0.4(10 \%$ EtOAc in hexanes $)$ 


\section{Alkenylation reactions}

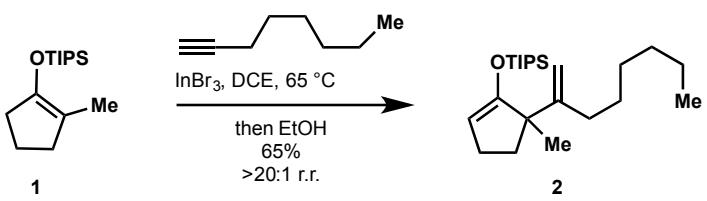

Silyl enol ether 2. Prepared according to "General procedure for the alkenylation of silyl enol ethers" from silyl enol ether $1^{2}$ (ratio of tetra- and trisubstituted isomers $\geq 10: 1$ ) and 1-octyne. The reaction was performed in solution on a $0.50 \mathrm{mmol}$ scale with 0.1 equiv of $\mathrm{InBr}_{3}$. The reaction mixture was heated to 50 ${ }^{\circ} \mathrm{C}$ for $23 \mathrm{~h}$. The alkenylation proceeded in $65 \%$ yield $(0.32 \mathrm{mmol}, 0.12 \mathrm{~g}$ of silyl enol ether 2 obtained, $>20: 1$ r.r.).

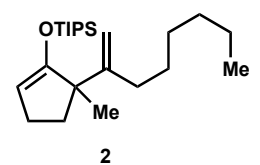

Silyl enol ether 2

${ }^{1} \mathrm{H}$ NMR (600 MHz, $\mathrm{CDCl}_{3}$ ):

$\delta 4.90(\mathrm{~d}, \mathrm{~J}=1.2 \mathrm{~Hz}, 1 \mathrm{H})$

$1.49-1.43(\mathrm{~m}, 2 \mathrm{H})$

$4.77(\mathrm{~d}, \mathrm{~J}=1.4 \mathrm{~Hz}, 1 \mathrm{H})$

1.33-1.26 (m, 6H)

$4.53(\mathrm{t}, \mathrm{J}=2.3 \mathrm{~Hz}, 1 \mathrm{H})$

$1.23(\mathrm{~s}, 3 \mathrm{H})$

2.20-2.17 (m, 2H)

1.21-1.15 (m, 3H)

2.03-2.00 (m, 2H)

$1.09-1.05(\mathrm{~m}, 18 \mathrm{H})$

1.98-1.93 (m, 1H)

$0.88(\mathrm{t}, \mathrm{J}=7.0 \mathrm{~Hz}, 3 \mathrm{H})$

$1.61(\mathrm{ddd}, \mathrm{J}=12.9,8.0,6.2 \mathrm{~Hz}, 1 \mathrm{H})$

$\left.{ }^{13} \mathrm{C} \mathrm{NMR} \mathrm{(125} \mathrm{MHz,} \mathrm{CDCl}_{3}\right)$ :

$\delta 159.2$

36.4

26.1

14.3

154.4

32.1

24.0

12.7

107.1

31.8

22.9

99.4

29.7

18.22

53.0

28.7

18.20

HRMS (Cl) calculated for $\mathrm{C}_{23} \mathrm{H}_{44} \mathrm{OSi}[\mathrm{M}]^{+}: 364.3161$, found: 364.3161

TLC: Runs with solvent front in hexanes 


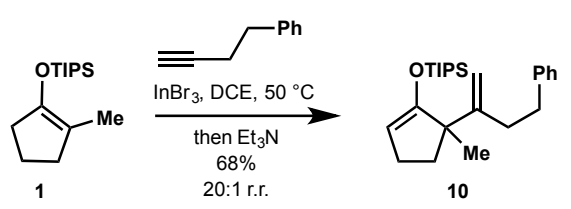

Silyl enol ether 10. Prepared according to "General procedure for the alkenylation of silyl enol ethers" from silyl enol ether $\mathbf{1}^{2}$ (ratio of tetra- and trisubstituted isomers $\geq 10: 1$ ) and phenethylacetylene. The reaction was performed in solution on a $0.50 \mathrm{mmol}$ scale with 0.1 equiv of $\mathrm{InBr}_{3}$. The reaction mixture was heated to $50{ }^{\circ} \mathrm{C}$ for $22 \mathrm{~h}$. The alkenylation proceeded in $68 \%$ yield $(130.5 \mathrm{mg}, 0.34 \mathrm{mmol}$ of silyl enol ether 10 obtained, 20:1 r.r.).

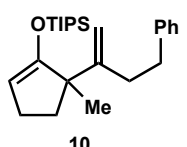

Silyl enol ether 10

${ }^{1} \mathrm{H}$ NMR (500 MHz, $\left.\mathrm{CDCl}_{3}\right)$ :

$\delta$ 7.29-7.27 (m, 2H)

2.22-2.14 (m, 2H)

7.21-7.16 (m, 3H) 1.96 (ddd, $\mathrm{J}=13.2,7.9,5.4 \mathrm{~Hz} 1 \mathrm{H}$ )

$4.99(\mathrm{~d}, \mathrm{~J}=0.96 \mathrm{~Hz}, 1 \mathrm{H})$ 1.63 (ddd, $\mathrm{J}=13.0,8.4,5.8 \mathrm{~Hz}, 1 \mathrm{H}$ )

$4.90(\mathrm{~d}, \mathrm{~J}=1.2 \mathrm{~Hz}, 1 \mathrm{H})$ $1.27(\mathrm{~s}, 3 \mathrm{H})$

$4.54(\mathrm{t}, \mathrm{J}=2.3 \mathrm{~Hz}, 1 \mathrm{H})$ 1.25-1.16 (m, 3H)

2.81-2.77 (m, 2H) 1.10-1.02 (m, 18H)

2.37-2.33 (m, 2H)

${ }^{13} \mathrm{C}$ NMR $\left(125 \mathrm{MHz}, \mathrm{CDCl}_{3}\right)$ :

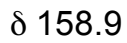

107.8

26.1

153.6

99.7

24.0

143.1

53.0

18.2

128.5

36.2

12.7

128.4

35.1

125.8

33.7

HRMS (Cl) calculated for $\mathrm{C}_{25} \mathrm{H}_{41} \mathrm{OSi}[\mathrm{M}+\mathrm{H}]^{+}: 385.2927$, found: 385.2936

TLC: $\mathrm{Rf}=0.6$ (hexanes) 


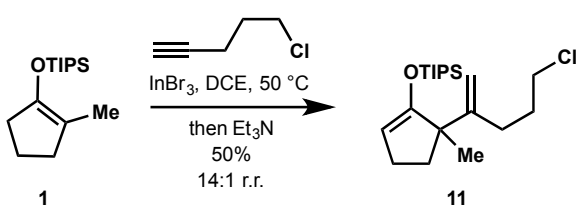

Silyl enol ether 11. Prepared according to "General procedure for the alkenylation of silyl enol ethers" from silyl enol ether $\mathbf{1}^{2}$ (ratio of tetra- and trisubstituted isomers $\geq 10: 1$ ) and 5-chloro-1-pentyne. The reaction was performed in solution on a $0.50 \mathrm{mmol}$ scale with 0.1 equiv of $\operatorname{InBr}_{3}$. The reaction mixture was heated to $50{ }^{\circ} \mathrm{C}$ for $26 \mathrm{~h}$. The alkenylation proceeded in $50 \%$ yield $(0.25 \mathrm{mmol}, 0.089 \mathrm{~g}$ of silyl enol ether 11 obtained, $14: 1$ r.r.).

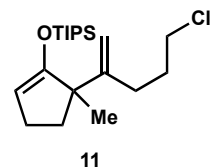

Silyl enol ether 11

${ }^{1} \mathrm{H}$ NMR $\left(500 \mathrm{MHz}, \mathrm{CDCl}_{3}\right)$ :

$\delta 4.95(\mathrm{~d}, 1 \mathrm{H}, \mathrm{J}=0.79 \mathrm{~Hz}, 1 \mathrm{H})$

$1.99-1.92(\mathrm{~m}, 3 \mathrm{H})$

$4.78(\mathrm{~d}, \mathrm{~J}=0.97 \mathrm{~Hz}, 1 \mathrm{H})$

1.63 (ddd, $\mathrm{J}=13.0,8.0,6.2,2 \mathrm{H}$ )

$4.55(\mathrm{t}, \mathrm{J}=2.4 \mathrm{~Hz}, 1 \mathrm{H})$

$1.24(\mathrm{~s}, 3 \mathrm{H})$

$3.55(\mathrm{t}, \mathrm{J}=6.6 \mathrm{~Hz}, 2 \mathrm{H})$

$1.23-1.15(\mathrm{~m}, 3 \mathrm{H})$

2.23-2.14 (m, 4H)

$1.11-1.03(\mathrm{~m}, 18 \mathrm{H})$

${ }^{13} \mathrm{C} \mathrm{NMR}\left(125 \mathrm{MHz}, \mathrm{CDCl}_{3}\right)$ :

$\delta 158.7$

45.2

23.9

152.5

36.2

18.11

108.0

31.7

18.09

99.7

28.9

12.6

52.9

25.9

HRMS (Cl) calculated for $\mathrm{C}_{20} \mathrm{H}_{37} \mathrm{ClOSi}[\mathrm{M}]^{+}: 356.2302$, found: 356.2309

TLC: $\mathrm{Rf}=0.65$ (hexanes) 


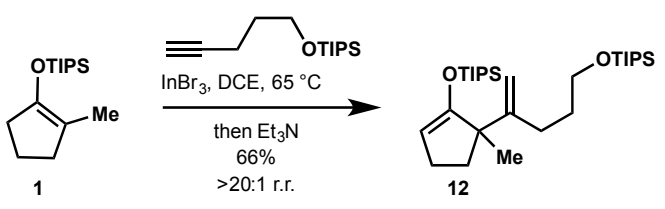

Silyl enol ether 12. Prepared according to "General procedure for the alkenylation of silyl enol ethers" from silyl enol ether $\mathbf{1}^{2}$ (ratio of tetra- and trisubstituted isomers $\geq 10: 1$ ) and alkyne 60 . The reaction was performed in solution on a $0.50 \mathrm{mmol}$ scale with 0.1 equiv of $\mathrm{InBr}_{3}$. The reaction mixture was heated to 65 ${ }^{\circ} \mathrm{C}$ for $23 \mathrm{~h}$. The alkenylation proceeded in $66 \%$ yield $(0.16 \mathrm{~g}, 0.33 \mathrm{mmol}$ of silyl enol ether 12 obtained, $>20: 1$ r.r.).

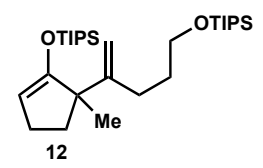

Silyl enol ether 12

${ }^{1} \mathrm{H}$ NMR $\left(500 \mathrm{MHz}, \mathrm{CDCl}_{3}\right)$ :

$\delta 4.91(\mathrm{~d}, \mathrm{~J}=0.91 \mathrm{~Hz}, 1 \mathrm{H})$

1.99-1.94 (m, 1H)

$4.80(\mathrm{~d}, \mathrm{~J}=1.3 \mathrm{~Hz}, 1 \mathrm{H})$

1.76-1.71 (m, 2H)

$4.53(\mathrm{t}, \mathrm{J}=2.3 \mathrm{~Hz}, 1 \mathrm{H})$

1.64-1.59 (m, 1H)

3.74-3.66 (m, 2H)

$1.24(\mathrm{~s}, 3 \mathrm{H})$

2.20-2.15 (m, 2H)

1.22-1.16 $(\mathrm{m}, 3 \mathrm{H})$

$2.12(\mathrm{dd}, \mathrm{J}=9.9,6.1 \mathrm{~Hz}, 1 \mathrm{H})$

1.11-1.02 (m, 39H)

2.08-2.02 (m, 1H)

${ }^{13} \mathrm{C}$ NMR $\left(125 \mathrm{MHz}, \mathrm{CDCl}_{3}\right)$ :

ठ 159.1

53.1

24.0

153.8

36.3

18.2

107.4

32.3

12.7

99.5

27.9

12.2

63.7

26.0

HRMS (Cl) calculated for $\mathrm{C}_{29} \mathrm{H}_{58} \mathrm{O}_{2} \mathrm{Si}_{2}[\mathrm{M}]^{+}: 494.3976$, found: 494.3981

TLC: $\mathrm{Rf}=0.35$ (hexanes) 


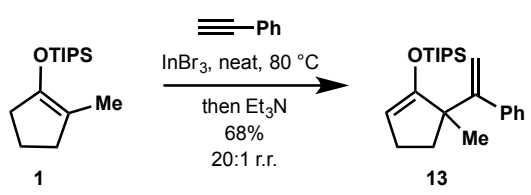

Silyl enol ether 13. Prepared according to "General procedure for the alkenylation of silyl enol ethers" from silyl enol ether $\mathbf{1}^{2}$ (ratio of tetra- and trisubstituted isomers $\geq 10: 1$ ) and phenylacetylene. The reaction was performed in the absence of solvent on a $0.50 \mathrm{mmol}$ scale with 0.05 equiv of $\operatorname{lnBr}_{3}$. The reaction mixture was heated to $80{ }^{\circ} \mathrm{C}$ for $26 \mathrm{~h}$. The alkenylation proceeded in $73 \%$ yield $(0.36 \mathrm{mmol}, 0.13 \mathrm{~g}$ of silyl enol ether 13 obtained, 20:1 r.r.).

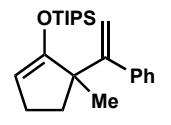

13

Silyl enol ether 13

${ }^{1} \mathrm{H}$ NMR (500 MHz, $\mathrm{CDCl}_{3}$ ):

ठ 7.29-7.22 (m, 5H)

2.02-1.96 (m, 1H)

$5.22(\mathrm{~d}, \mathrm{~J}=1.7 \mathrm{~Hz}, 1 \mathrm{H})$

1.72-1.67 (m, 1H)

$4.99(\mathrm{~d}, \mathrm{~J}=1.7 \mathrm{~Hz}, 1 \mathrm{H})$

$1.29(\mathrm{~s}, 3 \mathrm{H})$

$4.57(\mathrm{t}, \mathrm{J}=2.3 \mathrm{~Hz}, 1 \mathrm{H})$

1.26-1.19 (m, 3H)

2.17-2.06 (m, 2H)

$1.11-1.09(\mathrm{~m}, 18 \mathrm{H})$

${ }^{13} \mathrm{C}$ NMR $\left(125 \mathrm{MHz}, \mathrm{CDCl}_{3}\right)$ :

ठ 158.4

126.5

25.8

154.9

114.1

24.9

143.5

100.5

18.27

128.7

52.7

18.25

127.5

36.8

12.7

HRMS (Cl) calculated for $\mathrm{C}_{23} \mathrm{H}_{36} \mathrm{OSi}[\mathrm{M}]^{+}: 356.2535$, found: 356.2522

TLC: $\mathrm{Rf}=0.75$ (hexanes) 


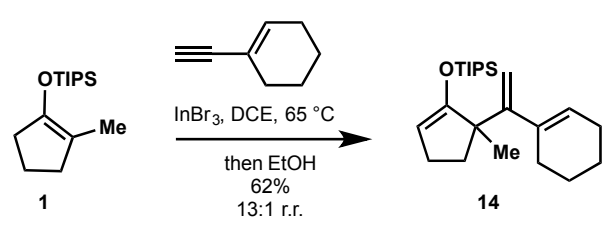

Silyl enol ether 14. Prepared according to "General procedure for the alkenylation of silyl enol ethers" from silyl enol ether $1^{2}$ (ratio of tetra- and trisubstituted isomers $\geq 10: 1$ ) and 1-ethynylcyclohexene. The reaction was performed in solution ( $5 \mathrm{M}$ in the silyl enol ether) on a $0.50 \mathrm{mmol}$ scale with 0.05 equiv of $\mathrm{InBr}_{3}$. The reaction mixture was heated to $80{ }^{\circ} \mathrm{C}$ for $26 \mathrm{~h}$. The alkenylation proceeded in $51 \%$ yield $(0.26$ $\mathrm{mmol}, 0.078 \mathrm{~g}$ of silyl enol ether 14 obtained, $13: 1$ r.r.).

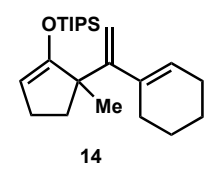

Silyl enol ether 14

${ }^{1} \mathrm{H}$ NMR $\left(500 \mathrm{MHz}, \mathrm{CDCl}_{3}\right)$ :

$\delta$ 5.57-5.55 (m, 1H)

$1.68-1.58(\mathrm{~m}, 3 \mathrm{H})$

$4.88(\mathrm{~d}, \mathrm{~J}=2.1 \mathrm{~Hz}, 1 \mathrm{H})$

$1.57-1.52(\mathrm{~m}, 2 \mathrm{H})$

$4.83(\mathrm{~d}, \mathrm{~J}=2.1 \mathrm{~Hz}, 1 \mathrm{H})$

1.23-1.15 $(\mathrm{m}, 6 \mathrm{H})$

$4.51(\mathrm{t}, \mathrm{J}=2.3 \mathrm{~Hz}, 1 \mathrm{H})$

1.10-1.04 (m, 18H)

2.22-2.15 (m, 3H)

2.14-2.08 (m, 1H)

2.06-2.00 (m, 3H)

${ }^{13} \mathrm{C} \mathrm{NMR}\left(125 \mathrm{MHz}, \mathrm{CDCl}_{3}\right)$ :

$\delta 159.5$

52.1

23.3

156.9

37.3

22.3

139.9

29.9

18.3

123.9

25.8

18.2

110.5

25.6

12.7

99.3

25.0

HRMS (CI) calculated for $\mathrm{C}_{23} \mathrm{H}_{40} \mathrm{OSi}[\mathrm{M}]^{+}: 360.2849$, found: 360.2851

TLC: $\mathrm{Rf}=0.9$ (hexanes) 


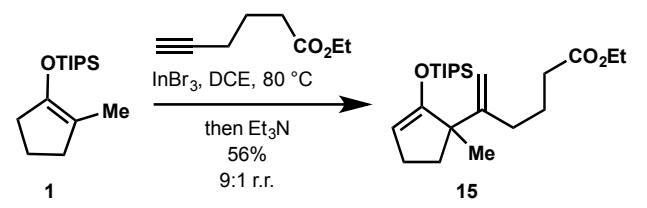

Silyl enol ether 15. Prepared according to "General procedure for the alkenylation of silyl enol ethers" from silyl enol ether $1^{2}$ (ratio of tetra- and trisubstituted isomers $\geq 10: 1$ ) and alkyne $61{ }^{3}$ The reaction was performed in solution on a $0.25 \mathrm{mmol}$ scale with 0.1 equiv of $\mathrm{InBr}_{3}$. The reaction mixture was heated to 80 ${ }^{\circ} \mathrm{C}$ for $23 \mathrm{~h}$. The alkenylation proceeded in $56 \%$ yield $(0.14 \mathrm{mmol}, 0.047 \mathrm{~g}$ of silyl enol ether 15 obtained, 9:1 r.r.).

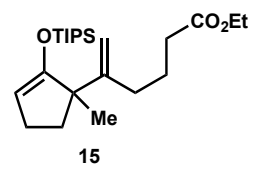

Silyl enol ether 15

${ }^{1} \mathrm{H}$ NMR $\left(500 \mathrm{MHz}, \mathrm{CDCl}_{3}\right)$ :

$\delta 5.01(\mathrm{~d}, \mathrm{~J}=1.0 \mathrm{~Hz}, 1 \mathrm{H})$

1.99 (ddd, $\mathrm{J}=13.5,7.5,5.9 \mathrm{~Hz}, 1 \mathrm{H})$

$4.86(\mathrm{~d}, \mathrm{~J}=1.0 \mathrm{~Hz}, 1 \mathrm{H})$

$1.91-1.85(\mathrm{~m}, 2 \mathrm{H})$

$4.60(\mathrm{t}, \mathrm{J}=2.3 \mathrm{~Hz}, 1 \mathrm{H})$

$1.68(\mathrm{ddd}, \mathrm{J}=13.0,8.3,5.9 \mathrm{~Hz}, 1 \mathrm{H}$ )

$4.18(\mathrm{q}, \mathrm{J}=7.1 \mathrm{~Hz}, 2 \mathrm{H})$

$1.31(\mathrm{t}, \mathrm{J}=7.0 \mathrm{~Hz}, 3 \mathrm{H})$

$2.38(\mathrm{td}, \mathrm{J}=7.6,1.2 \mathrm{~Hz}, 2 \mathrm{H})$

$1.30(\mathrm{~s}, 3 \mathrm{H})$

2.28-2.20 (m, 2H)

$1.28-1.20(\mathrm{~m}, 3 \mathrm{H})$

2.16-2.07 (m, 2H)

$1.13-1.11(\mathrm{~m}, 18 \mathrm{H})$

${ }^{13} \mathrm{C} \mathrm{NMR}\left(125 \mathrm{MHz}, \mathrm{CDCl}_{3}\right)$ :

$\begin{array}{lrl}\delta 173.8 & 52.9 & 23.8 \\ 158.9 & 36.2 & 18.10 \\ 152.9 & 34.4 & 18.08 \\ 107.8 & 31.0 & 14.3 \\ 99.5 & 25.9 & 12.6 \\ 60.2 & 24.0 & \\ \text { HRMS (ESI) calculated for } \mathrm{C}_{23} \mathrm{H}_{42} \mathrm{O}_{3} \mathrm{SiNa}[\mathrm{M}+\mathrm{Na}]^{+}: \text {417.2801, found: } 417.2794 \\ \text { TLC: } \mathrm{Rf}=0.5(5 \% \text { EtOAc in hexanes) }\end{array}$




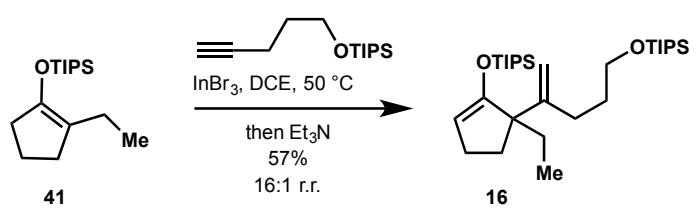

Silyl enol ether 16. Prepared according to "General procedure for the alkenylation of silyl enol ethers" from silyl enol ether 41 (ratio of tetra- and trisubstituted isomers 10:1) and alkyne 60. The reaction was performed in solution on a $0.50 \mathrm{mmol}$ scale with 0.1 equiv of $\mathrm{InBr}_{3}$. The reaction mixture was heated to 65 ${ }^{\circ} \mathrm{C}$ for $23 \mathrm{~h}$. The alkenylation proceeded in $57 \%$ yield $(145.1 \mathrm{mg}, 0.29 \mathrm{mmol}$ of silyl enol ether 16 obtained, $16: 1$ r.r.).

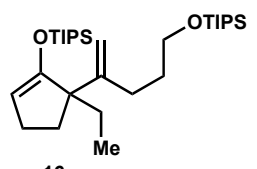

Silyl enol ether 16

${ }^{1} \mathrm{H}$ NMR $\left(500 \mathrm{MHz}, \mathrm{CDCl}_{3}\right)$ :

$\delta 4.93(\mathrm{~s}, 1 \mathrm{H})$

$1.63-1.56(\mathrm{~m}, 1 \mathrm{H})$

$4.81(\mathrm{~s}, 1 \mathrm{H})$

1.24-1.14 (m, 3H)

$4.58(\mathrm{t}, \mathrm{J}=2.3 \mathrm{~Hz}, 1 \mathrm{H})$

1.13-0.99 (m, 39H)

3.73-3.66 (m, 2H)

$0.85(\mathrm{t}, \mathrm{J}=7.4 \mathrm{~Hz}, 3 \mathrm{H})$

2.23-1.98 $(\mathrm{m}, 5 \mathrm{H})$

1.90 (ddd, J = 13.0, 8.9, $4.0 \mathrm{~Hz}, 1 \mathrm{H}$ )

1.76-1.65 (m, 3H)

${ }^{13} \mathrm{C}$ NMR $\left(125 \mathrm{MHz}, \mathrm{CDCl}_{3}\right)$ :

$\delta 157.3$

32.4

18.15

153.0

32.2

18.1

107.4

28.3

12.7

100.6

28.1

12.1

63.7

26.4

9.2

56.8

18.18

HRMS (Cl) calculated for $\mathrm{C}_{30} \mathrm{H}_{60} \mathrm{O}_{2} \mathrm{Si}_{2}[\mathrm{M}]^{+}: 508.4132$, found: 508.4117

TLC: $\mathrm{Rf}=0.4$ (hexanes) 


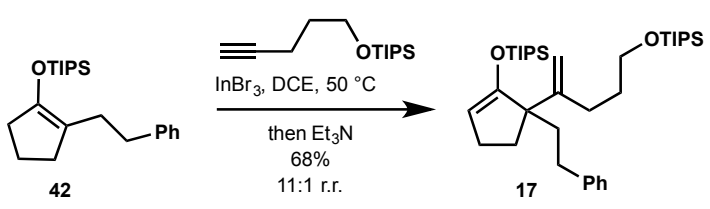

Silyl enol ether 17. Prepared according to "General procedure for the alkenylation of silyl enol ethers" from silyl enol ether 42 (ratio of tetra- and trisubstituted isomers $>10: 1$ ) and alkyne $\mathbf{6 0}$. The reaction was performed in solution on a $0.50 \mathrm{mmol}$ scale with 0.1 equiv of $\mathrm{InBr}_{3}$. The reaction mixture was heated to 50 ${ }^{\circ} \mathrm{C}$ for $70 \mathrm{~h}$. The alkenylation proceeded in $68 \%$ yield $(198.4 \mathrm{mg}, 0.34 \mathrm{mmol}$ of silyl enol ether 17 obtained, 11:1 r.r.).

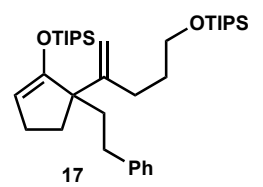

Silyl enol ether 17

${ }^{1} \mathrm{H}$ NMR $\left(500 \mathrm{MHz}, \mathrm{CDCl}_{3}\right)$ :

$\delta$ 7.29-7.25 (m, 2H)

2.28-2.16 $(\mathrm{m}, 3 \mathrm{H})$

7.19-7.15 (m, 3H)

2.15-2.08 (m, 1H)

$5.00(\mathrm{~s}, 1 \mathrm{H})$

2.04-1.98 $(\mathrm{m}, 1 \mathrm{H})$

$4.85(\mathrm{~s}, 1 \mathrm{H})$

1.95-1.89 (m, 2H)

$4.65(\mathrm{t}, \mathrm{J}=2.3 \mathrm{~Hz}, 1 \mathrm{H})$

1.89-1.81 $(\mathrm{m}, 1 \mathrm{H})$

$3.71(\mathrm{td}, \mathrm{J}=6.5,2.4 \mathrm{~Hz}, 2 \mathrm{H})$

$1.78-1.70(\mathrm{~m}, 2 \mathrm{H})$

2.69-2.62 (m, 1H)

1.27-1.18 (m, 3H)

2.61-2.54 (m, 1H)

$1.14-1.00(\mathrm{~m}, 39 \mathrm{H})$

${ }^{13} \mathrm{C}$ NMR $\left(125 \mathrm{MHz}, \mathrm{CDCl}_{3}\right)$ :

$\delta 157.3$

152.8

143.8

128.5

128.4

125.6
107.8

101.1

63.7

56.6

38.7

33.5
18.2

31.5

12.8

28.2

12.2

HRMS (Cl) calculated for $\mathrm{C}_{36} \mathrm{H}_{64} \mathrm{O}_{2} \mathrm{Si}_{2}[\mathrm{M}]^{+}: 584.4445$, found: 584.4560

TLC: $\mathrm{Rf}=0.25$ (2\% EtOAc in hexanes) 


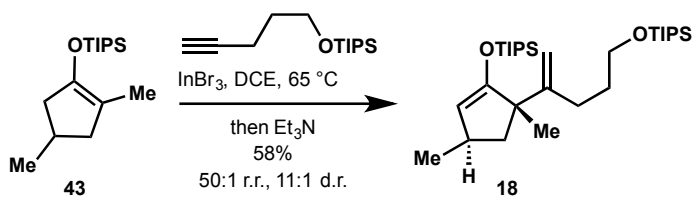

Silyl enol ether 18. Prepared according to "General procedure for the alkenylation of silyl enol ethers" from silyl enol ether $\mathbf{4 3}$ (ratio of tetra- and trisubstituted isomers $>10: 1$ ) and alkyne $\mathbf{6 0}$. The reaction was performed in solution on a $0.50 \mathrm{mmol}$ scale with 0.1 equiv of $\mathrm{InBr}_{3}$. The reaction mixture was heated to 65 ${ }^{\circ} \mathrm{C}$ for $23 \mathrm{~h}$. The alkenylation proceeded in $58 \%$ yield $(0.29 \mathrm{mmol}, 0.15 \mathrm{~g}$ of silyl enol ether 18 obtained, $11: 1$ d.r., $>20: 1$ r.r.).

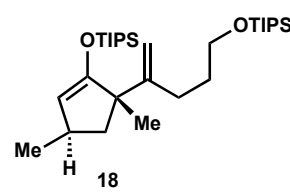

Silyl enol ether 18

${ }^{1} \mathrm{H}$ NMR (500 MHz, $\left.\mathrm{CDCl}_{3}\right)$ :

$\delta 4.96(\mathrm{~d}, \mathrm{~J}=1.0 \mathrm{~Hz}, 1 \mathrm{H})$

$1.31(\mathrm{~s}, 3 \mathrm{H})$

$4.82(\mathrm{~d}, \mathrm{~J}=1.3 \mathrm{~Hz}, 1 \mathrm{H})$

1.27-1.20 (m, 4H)

$4.55(\mathrm{~d}, \mathrm{~J}=1.9 \mathrm{~Hz}, 1 \mathrm{H})$

1.18-1.10 (m, 39H)

3.81-3.71 (m, 2H)

$1.05(\mathrm{~d}, \mathrm{~J}=6.8 \mathrm{~Hz}, 3 \mathrm{H})$

2.70-2.62 (m, 1H)

2.26-2.08 (m, 3H)

1.85-1.74 (m, 2H)

${ }^{13} \mathrm{C}$ NMR (125 MHz, $\left.\mathrm{CDCl}_{3}\right)$ :

$\delta 158.0$

45.6

18.12

153.6

33.6

18.09

106.9

32.2

12.6

106.5

27.8

12.0

63.6

25.7

53.8

23.2

HRMS (Cl) calculated for $\mathrm{C}_{30} \mathrm{H}_{60} \mathrm{O}_{2} \mathrm{Si}_{2}[\mathrm{M}]^{+}: 508.4132$, found: 508.4178

TLC: $\mathrm{Rf}=0.65$ (hexanes) 


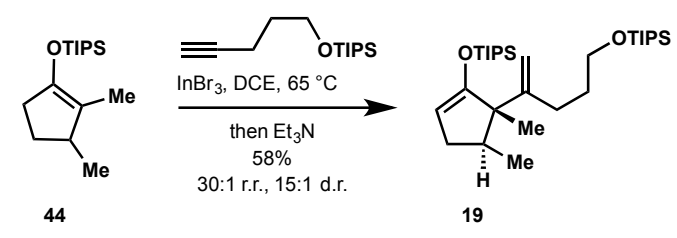

Silyl enol ether 19. Prepared according to "General procedure for the alkenylation of silyl enol ethers" from silyl enol ether 44 (ratio of tetra- and trisubstituted isomers $>10: 1$ ) and alkyne $\mathbf{6 0}$. The reaction was performed in solution on a $0.50 \mathrm{mmol}$ scale with 0.1 equiv of $\mathrm{InBr}_{3}$. The reaction mixture was heated to 65 ${ }^{\circ} \mathrm{C}$ for $23 \mathrm{~h}$. The isolated product was further purified by heating to $50{ }^{\circ} \mathrm{C}$ under vacuum (ca. 0.1 torr) to remove the remaining alkyne. The alkenylation proceeded in $58 \%$ yield $(0.29 \mathrm{mmol}, 0.15 \mathrm{~g}$ of silyl enol ether 19 obtained, 15:1 d.r., >20:1 r.r.).

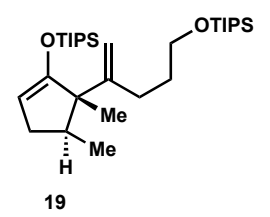

Silyl enol ether 19

${ }^{1} \mathrm{H}$ NMR $\left(500 \mathrm{MHz}, \mathrm{CDCl}_{3}\right)$ :

$\delta$ 4.88-4.87 (m, 2H)

$1.81(\mathrm{ddd}, \mathrm{J}=13.8,8.3,1.7 \mathrm{~Hz}, 1 \mathrm{H})$

$4.49(\mathrm{t}, \mathrm{J}=2.2 \mathrm{~Hz}, 1 \mathrm{H})$

$1.75-1.70(\mathrm{~m}, 2 \mathrm{H})$

3.72-3.64 (m, 2H)

1.20-1.14 (m, 3H)

2.29 (ddd, J = 13.7, 7.9, $2.6 \mathrm{~Hz}, 1 \mathrm{H}$ )

1.10-1.04 (m, 42H)

2.27-2.20 (m, 1H)

$0.85(\mathrm{~d}, \mathrm{~J}=6.9 \mathrm{~Hz}, 3 \mathrm{H})$

2.18-2.11 (m, 1H)

2.07-2.00 (m, 1H)

${ }^{13} \mathrm{C} \mathrm{NMR}\left(125 \mathrm{MHz}, \mathrm{CDCl}_{3}\right)$ :

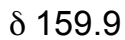

38.6

16.5

153.1

34.6

14.4

108.5

32.5

12.6

98.8

27.7

12.1

63.6

18.08

55.4

18.06

HRMS (Cl) calculated for $\mathrm{C}_{30} \mathrm{H}_{60} \mathrm{O}_{2} \mathrm{Si}_{2}[\mathrm{M}]^{+}: 508.4132$, found: 508.4130

TLC: $\mathrm{Rf}=0.57$ (hexanes) 


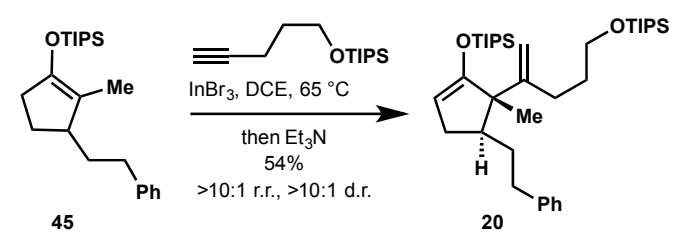

Silyl enol ether 20. Prepared according to "General procedure for the alkenylation of silyl enol ethers" from silyl enol ether 45 (ratio of tetra- and trisubstituted isomers $>10: 1$ ) and alkyne $\mathbf{6 0}$. The reaction was performed in solution on a $0.50 \mathrm{mmol}$ scale with 0.1 equiv of $\mathrm{InBr}_{3}$. The reaction mixture was heated to 65 ${ }^{\circ} \mathrm{C}$ for $44 \mathrm{~h}$. The alkenylation proceeded in $54 \%$ yield $(161.9 \mathrm{mg}, 0.27 \mathrm{mmol}$ of silyl enol ether 20 obtained). The minor isomer (ratio $>10: 1$ ) could not be unambiguously assigned as diastereomer or regioisomer.

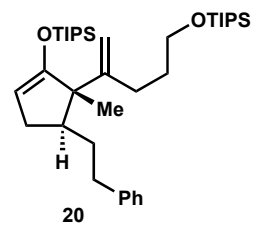

Silyl enol ether 20

${ }^{1} \mathrm{H}$ NMR $\left(500 \mathrm{MHz}, \mathrm{CDCl}_{3}\right)$ :

$\delta$ 7.27-7.24 (m, 2H)

2.18-2.15 (m, 1H)

7.17-7.14 (m, 3H)

2.11-2.05 (m, 1H)

$4.90(\mathrm{~s}, 2 \mathrm{H})$

2.03-1.96 $(\mathrm{m}, 1 \mathrm{H})$

$4.51(\mathrm{t}, \mathrm{J}=2.2 \mathrm{~Hz}, 1 \mathrm{H})$

1.90 (ddd, $\mathrm{J}=14.1,9.1,1.8 \mathrm{~Hz}, 1 \mathrm{H}$ )

3.67-3.62 (m, 2H)

1.71-1.63 (m, 3H)

2.65-2.60 $(\mathrm{m}, 1 \mathrm{H})$

1.56-1.50 (m, 1H)

2.51-2.45 $(\mathrm{m}, 1 \mathrm{H})$

1.19-1.14 (m, 3H)

2.39 (ddd, J = 14.1, 7.9, $2.9 \mathrm{~Hz}, 1 \mathrm{H}$ )

1.09-1.04 (m, 42H)

${ }^{13} \mathrm{C}$ NMR $\left(125 \mathrm{MHz}, \mathrm{CDCl}_{3}\right)$ :

$\delta 160.0$

109.0

32.8

16.8

153.0

98.4

32.5

12.6

143.0

63.7

32.0

12.1

128.34

55.4

27.8

128.26

43.5

18.11

125.6

34.4

18.08

HRMS (Cl) calculated for $\mathrm{C}_{37} \mathrm{H}_{66} \mathrm{O}_{2} \mathrm{Si}_{2}[\mathrm{M}+\mathrm{H}]^{+}: 598.4601$, found: 598.4614

TLC: $\mathrm{Rf}=0.8$ (5\% EtOAc in hexanes) 

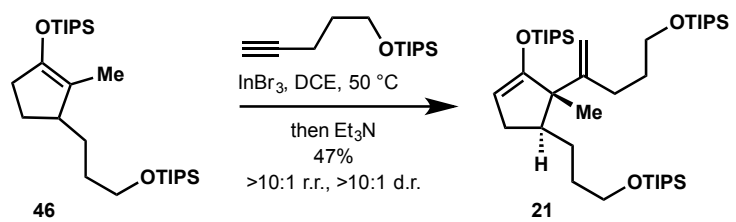

Silyl enol ether 21. Prepared according to "General procedure for the alkenylation of silyl enol ethers" from silyl enol ether 46 (ratio of tetra- and trisubstituted isomers $>10: 1$ ) and alkyne $\mathbf{6 0}$. The reaction was performed in solution on a $0.50 \mathrm{mmol}$ scale with 0.1 equiv of $\mathrm{InBr}_{3}$. The reaction mixture was heated to 50 ${ }^{\circ} \mathrm{C}$ for $48 \mathrm{~h}$. The product was isolated by flash chromatography (elution 0.5 to $1 \%$ EtOAc in hexanes) and then heated to $50{ }^{\circ} \mathrm{C}$ under vacuum (ca. 0.1 torr) to remove remaining alkyne. The alkenylation proceeded in $48 \%$ yield $(0.24 \mathrm{mmol}, 0.17 \mathrm{~g}$ of silyl enol ether 21 obtained). The minor isomer (ratio >10:1) could not be unambiguously assigned as diastereomer or regioisomer.

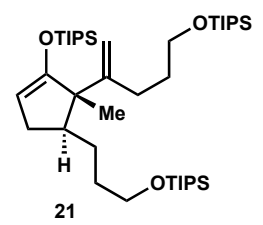

Silyl enol ether $\mathbf{2 1}$

${ }^{1} \mathrm{H}$ NMR (500 MHz, $\left.\mathrm{CDCl}_{3}\right)$ :

$\delta 4.88(\mathrm{~s}, 2 \mathrm{H})$

$1.55-151(\mathrm{~m}, 1 \mathrm{H})$

$4.49(\mathrm{t}, \mathrm{J}=2.1 \mathrm{~Hz}, 1 \mathrm{H})$

1.49-1.32 (m, 2H)

3.73-3.61 (m, 4H)

1.26-1.15 $(\mathrm{m}, 4 \mathrm{H})$

2.32 (ddd, $\mathrm{J}=14.1,7.9,2.8 \mathrm{~Hz}, 1 \mathrm{H}$ )

$1.11-0.96(\mathrm{~m}, 63 \mathrm{H})$

2.18-1.97 (m, 3H)

1.82 (ddd, $\mathrm{J}=14.2,9.1,1.7 \mathrm{~Hz}, 1 \mathrm{H}$ )

1.75-1.68 (m, 2H)

${ }^{13} \mathrm{C}$ NMR (125 MHz, $\mathrm{CDCl}_{3}$ ):

$\delta 160.1$

55.5

26.2

153.2

43.9

18.2

108.9

32.9

16.8

98.6

32.7

12.7

64.0

31.7

12.2

63.9

28.0

HRMS (ESI) calculated for $\mathrm{C}_{41} \mathrm{H}_{84} \mathrm{O}_{3} \mathrm{Si}_{3} \mathrm{Na}[\mathrm{M}+\mathrm{Na}]^{+}:$731.5626, found: 731.5621

TLC: $R f=0.65$ (hexanes) 


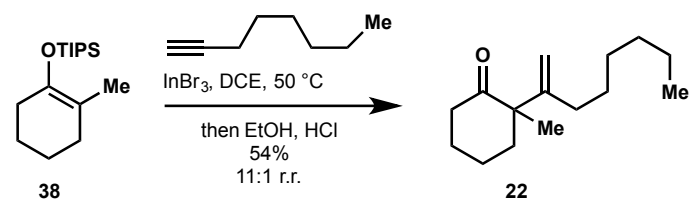

Ketone 22. Prepared according to "General procedure for the alkenylation of silyl enol ethers" from silyl enol ether 38 (ratio of tetra- and trisubstituted isomers >10:1) and 1-octyne. The reaction was performed in solution on a $0.25 \mathrm{mmol}$ scale with 0.1 equiv of $\mathrm{InBr}_{3}$. The reaction mixture was heated to $50{ }^{\circ} \mathrm{C}$ for 64 h. The reaction was quenched with $1 \mathrm{~mL}$ of $\mathrm{EtOH}$ and $0.3 \mathrm{ml}$ of aqueous $\mathrm{HCl}(2 \mathrm{M})$ and the resulting solution was stirred for $3 \mathrm{~h}$. The alkenylation proceeded in $54 \%$ yield $(29.9 \mathrm{mg}, 0.13 \mathrm{mmol}$ of ketone 22 obtained, 11:1 r.r.).

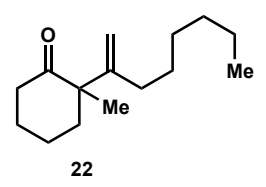

\section{Ketone 22}

${ }^{1} \mathrm{H}$ NMR $\left(500 \mathrm{MHz}, \mathrm{CDCl}_{3}\right)$ :

$\delta 4.98(\mathrm{t}, \mathrm{J}=1.6 \mathrm{~Hz}, 1 \mathrm{H})$

$1.46-1.43(\mathrm{~m}, 3 \mathrm{H})$

$4.88(\mathrm{~s}, 1 \mathrm{H})$

$1.30-1.27(\mathrm{~m}, 6 \mathrm{H})$

$2.50(\mathrm{td}, \mathrm{J}=13.1,6.0 \mathrm{~Hz}, 1 \mathrm{H})$

$1.10(\mathrm{~s}, 3 \mathrm{H})$

2.34-2.24 (m, 2H)

$0.88(\mathrm{t}, \mathrm{J}=7.0 \mathrm{~Hz}, 3 \mathrm{H})$

2.00-1.93 (m, 2H)

1.83-1.72 (m, 2H)

1.66-1.60 (m, 2H)

${ }^{13} \mathrm{C}$ NMR $\left(125 \mathrm{MHz}, \mathrm{CDCl}_{3}\right)$ :

$\delta 215.0$

32.0

22.8

150.9

31.5

22.1

110.1

29.4

14.2

56.0

28.3

40.2

28.2

38.1

25.0

HRMS (ESI) calculated for $\mathrm{C}_{15} \mathrm{H}_{26} \mathrm{ONa}[\mathrm{M}+\mathrm{Na}]^{+}: 245.1881$, found: 245.1874

TLC: $\mathrm{Rf}=0.58(10 \%$ EtOAc in hexanes $)$ 


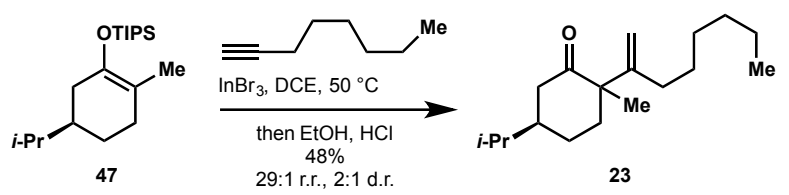

Ketone 23. Prepared according to "General procedure for the alkenylation of silyl enol ethers" from silyl enol ether $47^{2}$ and 1-octyne. The reaction was performed in solution on a $0.25 \mathrm{mmol}$ scale with 0.1 equiv of $\operatorname{InBr}_{3}$. The reaction mixture was heated to $50{ }^{\circ} \mathrm{C}$ for $64 \mathrm{~h}$. The reaction was quenched with $1 \mathrm{~mL}$ of $\mathrm{EtOH}$ and $0.3 \mathrm{ml}$ of aqueous $\mathrm{HCl}(2 \mathrm{M})$ and the resulting solution was stirred for $3 \mathrm{~h}$. The alkenylation proceeded in $48 \%$ yield $(31.5 \mathrm{mg}, 0.12 \mathrm{mmol}$ of ketone 23 obtained, 2:1 d.r., >20:1 r.r.).

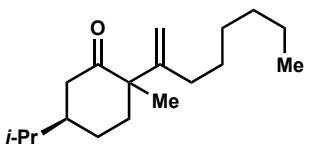

\section{Ketone 23}

${ }^{1} \mathrm{H}$ NMR (2:1 d.r., $\left.600 \mathrm{MHz}, \mathrm{CDCl}_{3}\right)$ :

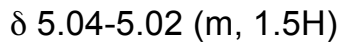
1.93-1.81 (m, 2H)
$5.00(\mathrm{~s}, 0.5 \mathrm{H})$
1.70-1.65 (m, 2H)
$4.93(\mathrm{~s}, 1 \mathrm{H})$
$1.57-1.50(\mathrm{~m}, 4.5 \mathrm{H})$
2.52-2.49 (m, 0.5H)
$1.46-1.41(\mathrm{~m}, 1.5 \mathrm{H})$
2.41-2.38 (m, 1H)
1.38-1.31 (m, 12H)
2.35-2.31 (m, 1.5H)
$1.27(\mathrm{~s}, 1.5 \mathrm{H})$
2.16-2.12 (m, 0.5H)
$1.15(\mathrm{~s}, 3 \mathrm{H})$
2.05-1.99 (m, 1.5H)
0.96-0.92 (m, 13.5H)

${ }^{13} \mathrm{C}$ NMR (2:1 d.r., $150 \mathrm{MHz}, \mathrm{CDCl}_{3}$ ):

$\begin{array}{llll}\delta 215.1 & 44.4 & 31.3 & 23.4 \\ 214.8 & 43.6 & 30.8 & 22.68 \\ 152.1 & 42.5 & 29.4 & 22.67 \\ 150.6 & 36.8 & 29.2 & 20.04 \\ 110.0 & 34.7 & 28.9 & 19.99 \\ 109.7 & 32.9 & 28.0 & 19.7 \\ 55.2 & 32.6 & 25.5 & 19.5 \\ 55.1 & 31.87 & 24.8 & 14.13 \\ 47.0 & 31.86 & 24.4 & 14.11\end{array}$

HRMS (ESI) calculated for $\mathrm{C}_{18} \mathrm{H}_{32} \mathrm{ONa}[\mathrm{M}+\mathrm{Na}]^{+}: 287.2351$, found: 287.2360

TLC: $R f=0.6(10 \%$ EtOAc in hexanes $)$ 


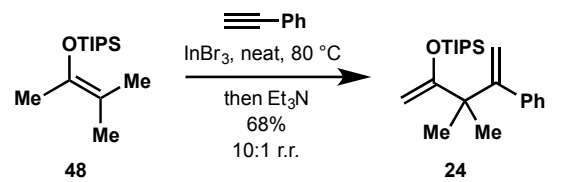

Silyl enol ether 24. Prepared according to "General procedure for the alkenylation of silyl enol ethers" from silyl enol ether 48 (ratio of tetra- and disubstituted isomers 7:1) and phenylacetylene. The reaction was performed in the absence of solvent on a $0.5 \mathrm{mmol}$ scale with 0.1 equiv of $\mathrm{InBr}_{3}$. The reaction mixture was heated to $80{ }^{\circ} \mathrm{C}$ for $72 \mathrm{~h}$. The alkenylation proceeded in $58 \%$ yield $(0.29 \mathrm{mmol}, 0.10 \mathrm{~g}$ of silyl enol ether 24 obtained; 7:1 r.r., minor 1,2-disubstituted alkene isomer is formed as a ca. 1:1 mixture of cis and trans diastereomers).

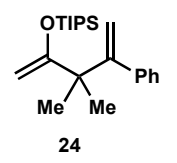

Silyl enol ether 24

${ }^{1} \mathrm{H}$ NMR (500 MHz, $\left.\mathrm{C}_{6} \mathrm{D}_{6}\right)$ :

$\delta 7.45-7.41(\mathrm{~m}, 2 \mathrm{H})$

$4.26(\mathrm{~d}, \mathrm{~J}=1.7 \mathrm{~Hz}, 1 \mathrm{H})$

7.20-7.16 (m, 2H)

$4.15(\mathrm{~d}, \mathrm{~J}=1.7 \mathrm{~Hz}, 1 \mathrm{H})$

7.12-7.09 (m, 1H)

$1.32(\mathrm{~s}, 6 \mathrm{H})$

$5.34(\mathrm{~d}, \mathrm{~J}=1.5 \mathrm{~Hz}, 1 \mathrm{H})$

1.29-1.07 (m, 21H)

$5.16(\mathrm{~d}, \mathrm{~J}=1.5 \mathrm{~Hz}, 1 \mathrm{H})$

${ }^{13} \mathrm{C}$ NMR (125 MHz, $\left.\mathrm{C}_{6} \mathrm{D}_{6}\right)$ :

ठ 164.4

114.7

155.8

88.2

143.5

46.1

129.0

27.6

127.7

18.5

127.0

13.3

HRMS (Cl) calculated for $\mathrm{C}_{22} \mathrm{H}_{37} \mathrm{OSi}[\mathrm{M}+\mathrm{H}]^{+}: 345.2614$, found: 345.2614

TLC: $R f=0.55$ (hexanes) 


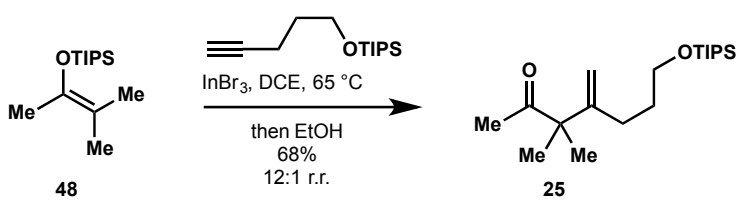

Ketone 25. Prepared according to "General procedure for the alkenylation of silyl enol ethers" from silyl enol ether $\mathbf{4 8}$ (ratio of tetra- and disubstituted isomers 7:1) and alkyne $\mathbf{6 0}$. The reaction was performed in solution on a $0.5 \mathrm{mmol}$ scale with 0.1 equiv of $\mathrm{InBr}_{3}$. The reaction mixture was heated to $65^{\circ} \mathrm{C}$ for $23 \mathrm{~h}$. The product was isolated by flash chromatography (elution hexanes to $1 \%$ EtOAc in hexanes). The alkenylation proceeded in $68 \%$ yield $(0.34 \mathrm{mmol}, 0.11 \mathrm{~g}$ of ketone 25 obtained, $12: 1$ r.r.).

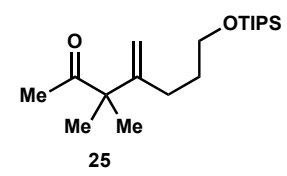

\section{Ketone 25}

${ }^{1} \mathrm{H}$ NMR $\left(500 \mathrm{MHz}, \mathrm{C}_{6} \mathrm{D}_{6}\right)$ :

$\delta 4.94(\mathrm{~d}, \mathrm{~J}=0.56 \mathrm{~Hz}, 1 \mathrm{H})$

$1.68-1.63(\mathrm{~m}, 2 \mathrm{H})$

$4.91(\mathrm{t}, \mathrm{J}=1.2 \mathrm{~Hz}, 1 \mathrm{H})$

$1.13(\mathrm{~s}, 6 \mathrm{H})$

$3.56(\mathrm{t}, \mathrm{J}=6.2 \mathrm{~Hz}, 2 \mathrm{H}$ )

1.12-1.08 (m, 18H)

2.02-1.98 (m, 2H)

1.07-1.02 (m, 3H)

$1.82(\mathrm{~s}, 3 \mathrm{H})$

${ }^{13} \mathrm{C}$ NMR (125 MHz, $\left.\mathrm{C}_{6} \mathrm{D}_{6}\right)$ :

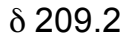

28.8

152.5

24.4

109.6

23.6

63.2

18.3

54.5

12.4

32.4

HRMS (ESI) calculated for $\mathrm{C}_{19} \mathrm{H}_{38} \mathrm{O}_{2} \mathrm{SiNa}[\mathrm{M}+\mathrm{Na}]^{+}: 349.2539$, found: 349.2526

TLC: $\mathrm{Rf}=0.3$ ( $5 \%$ EtOAc in hexanes) 

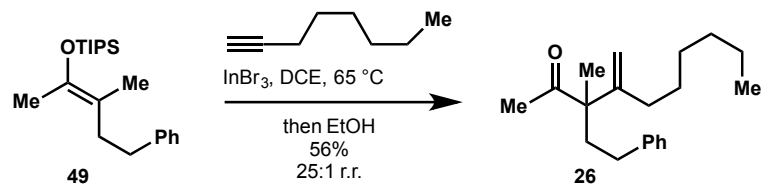

Ketone 26. Prepared according to "General procedure for the alkenylation of silyl enol ethers" from silyl enol ether 49 (ratio of tetra- and disubstituted isomers 7:1) and 1-octyne. The reaction was performed in solution on a $0.25 \mathrm{mmol}$ scale with 0.1 equiv of $\mathrm{InBr}_{3}$. The reaction mixture was heated to $65^{\circ} \mathrm{C}$ for $68 \mathrm{~h}$. The product was isolated by flash chromatography (elution with $20-50 \%$ DCM in hexanes). The alkenylation proceeded in $56 \%$ yield $(0.14 \mathrm{mmol}, 40 \mathrm{mg}$ of ketone 26 obtained, $>20: 1$ r.r. $)$.

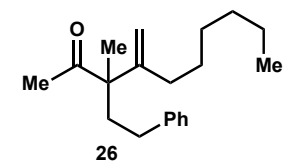

\section{Ketone 26}

${ }^{1} \mathrm{H}$ NMR $\left(600 \mathrm{MHz}, \mathrm{CDCl}_{3}\right)$ :

$\delta$ 7.29-7.26 (m, 2H)

$1.84-1.79(\mathrm{~m}, 1 \mathrm{H})$

7.20-7.16 $(\mathrm{m}, 3 \mathrm{H})$

$1.50-1.45(\mathrm{~m}, 2 \mathrm{H})$

$5.11(\mathrm{~m}, 2 \mathrm{H})$

$1.33-1.26(\mathrm{~m}, 9 \mathrm{H})$

$2.45-2.35(\mathrm{~m}, 2 \mathrm{H})$

$0.88(\mathrm{t}, \mathrm{J}=7.0 \mathrm{~Hz}, 3 \mathrm{H}$ )

$2.07(\mathrm{~s}, 3 \mathrm{H})$

2.02-1.93 (m, 2H)

1.93-1.87 $(\mathrm{m}, 1 \mathrm{H})$

${ }^{13} \mathrm{C}$ NMR $\left(125 \mathrm{MHz}, \mathrm{CDCl}_{3}\right)$ :

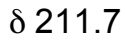

126.0

31.9

22.8

150.6

111.2

30.8

20.2

142.6

58.0

29.4

14.2

128.5

36.8

28.4

128.4

32.4

25.2

HRMS (ESI) calculated for $\mathrm{C}_{20} \mathrm{H}_{30} \mathrm{ONa}[\mathrm{M}+\mathrm{Na}]^{+}: 309.2194$, found: 309.2180

TLC: $\mathrm{Rf}=0.25\left(30 \% \mathrm{CH}_{2} \mathrm{Cl}_{2}\right.$ in hexanes $)$ 


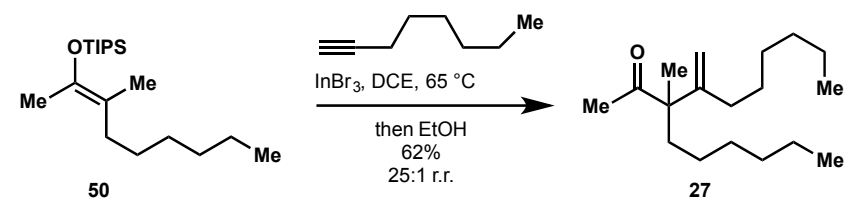

Ketone 27. Prepared according to "General procedure for the alkenylation of silyl enol ethers" from silyl enol ether 50 (ratio of tetra- and disubstituted isomers 9:1) and 1-octyne. The reaction was performed in solution on a $0.25 \mathrm{mmol}$ scale with 0.1 equiv of $\mathrm{InBr}_{3}$. The reaction mixture was heated to $65^{\circ} \mathrm{C}$ for $68 \mathrm{~h}$. The product was isolated by flash chromatography (elution with $20-40 \%$ DCM in hexanes). The alkenylation proceeded in $62 \%$ yield $(0.16 \mathrm{mmol}, 42 \mathrm{mg}$ of ketone 27 obtained, $>20: 1$ r.r. $)$.

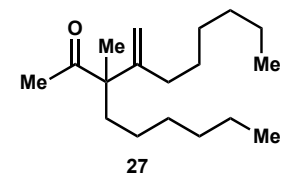

\section{Ketone 27}

${ }^{1} \mathrm{H}$ NMR $\left(500 \mathrm{MHz}, \mathrm{CDCl}_{3}\right)$ :

$\delta 5.04(\mathrm{~s}, 1 \mathrm{H})$

$1.18(\mathrm{~s}, 3 \mathrm{H})$

$5.03(\mathrm{~s}, 1 \mathrm{H})$

$1.11-0.99(\mathrm{~m}, 2 \mathrm{H})$

$2.01(\mathrm{~s}, 3 \mathrm{H})$

0.91-0.82 (m, 6H)

1.85-1.73 (m, 2H)

$1.70-1.60(\mathrm{~m}, 2 \mathrm{H})$

1.46-1.39 (m, 2H)

1.33-1.21 (m, 12H)

${ }^{13} \mathrm{C}$ NMR $\left(125 \mathrm{MHz}, \mathrm{CDCl}_{3}\right)$ :

б 212.4

151.3

110.8

58.2

34.9
32.5

32.04

32.01

30.3

29.5
28.5

25.3

24.3

22.91

22.88

HRMS (ESI) calculated for $\mathrm{C}_{18} \mathrm{H}_{34} \mathrm{ONa}[\mathrm{M}+\mathrm{Na}]^{+}: 289.2507$, found: 289.2498

TLC: $\mathrm{Rf}=0.45\left(30 \% \mathrm{CH}_{2} \mathrm{Cl}_{2}\right.$ in hexanes $)$ 

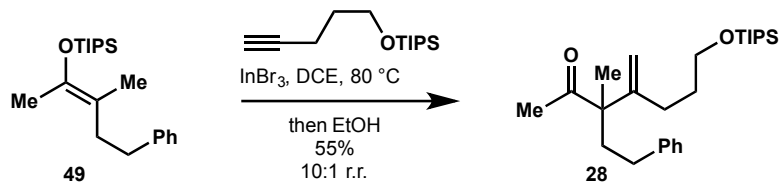

Ketone 28. Prepared according to "General procedure for the alkenylation of silyl enol ethers" from silyl enol ether 49 (ratio of tetra- and disubstituted isomers 7:1) and alkyne 60. The reaction was performed in solution on a $0.25 \mathrm{mmol}$ scale with 0.1 equiv of $\mathrm{InBr}_{3}$. The reaction mixture was heated to $80^{\circ} \mathrm{C}$ for $48 \mathrm{~h}$. The product was isolated by flash chromatography (elution with $20-40 \%$ DCM in hexanes), then heated to $50{ }^{\circ} \mathrm{C}$ under vacuum (ca. 0.1 torr) to remove remaining hydrolyzed starting material. The alkenylation proceeded in $55 \%$ yield $(0.14 \mathrm{mmol}, 57 \mathrm{mg}$ of ketone 28 obtained, $10: 1$ r.r. $)$.

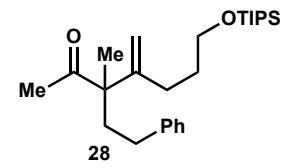

\section{Ketone 28}

${ }^{1} \mathrm{H}$ NMR $\left(500 \mathrm{MHz}, \mathrm{CDCl}_{3}\right)$ :

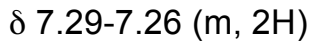

2.04-1.89 (m, 4H)

7.19-7.16 (m, 3H)

1.78-1.69 (m, 2H)

$5.13(\mathrm{~s}, 2 \mathrm{H})$

$1.32(\mathrm{~s}, 3 \mathrm{H})$

$3.70(\mathrm{t}, \mathrm{J}=6.3 \mathrm{~Hz}, 2 \mathrm{H})$

1.12-1.01 (m, 21H)

2.46-2.35 (m, 2H)

2.07 (s, 3H)

${ }^{13} \mathrm{C} \mathrm{NMR}\left(125 \mathrm{MHz}, \mathrm{CDCl}_{3}\right)$ :

$\delta 211.5$

125.9

31.8

18.2

150.3

111.3

30.8

12.1

142.6

63.1

28.6

128.5

58.0

25.2

128.4

36.9

20.2

HRMS (ESI) calculated for $\mathrm{C}_{26} \mathrm{H}_{44} \mathrm{O}_{2} \mathrm{SiNa}[\mathrm{M}+\mathrm{Na}]^{+}: 439.3008$, found: 439.2998

TLC: $\mathrm{Rf}=0.2\left(30 \% \mathrm{CH}_{2} \mathrm{Cl}_{2}\right.$ in hexanes $)$ 

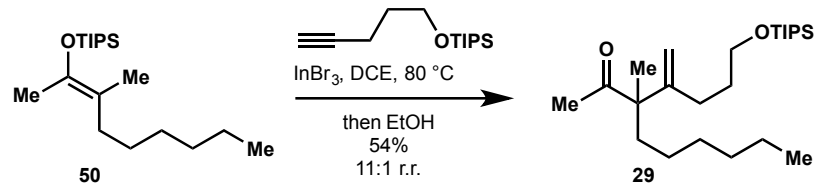

Ketone 29. Prepared according to "General procedure for the alkenylation of silyl enol ethers" from silyl enol ether 50 (ratio of tetra- and disubstituted isomers 9:1) and alkyne $\mathbf{6 0}$. The reaction was performed in solution on a $0.25 \mathrm{mmol}$ scale with 0.1 equiv of $\mathrm{InBr}_{3}$. The reaction mixture was heated to $80^{\circ} \mathrm{C}$ for $48 \mathrm{~h}$. The product was isolated by flash chromatography (elution with $20-50 \%$ DCM in hexanes), then heated to $50{ }^{\circ} \mathrm{C}$ under vacuum (ca. 0.1 torr) to remove remaining hydrolyzed starting material. The alkenylation proceeded in $54 \%$ yield $(0.14 \mathrm{mmol}, 53 \mathrm{mg}$ of ketone 29 obtained, $11: 1 \mathrm{r} . \mathrm{r}$. $)$.

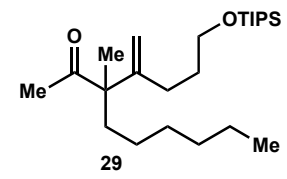

Ketone 29

${ }^{1} \mathrm{H}$ NMR $\left(500 \mathrm{MHz}, \mathrm{CDCl}_{3}\right)$ :

$\delta 5.05(\mathrm{~s}, 2 \mathrm{H})$

$131-1.22(\mathrm{~m}, 6 \mathrm{H})$

$3.68(\mathrm{t}, \mathrm{J}=6.3 \mathrm{~Hz}, 2 \mathrm{H}$ )

$1.19(\mathrm{~s}, 3 \mathrm{H})$

$2.01(\mathrm{~s}, 3 \mathrm{H})$

1.13-0.98 $(\mathrm{m}, 21 \mathrm{H})$

1.98-1.84 (m, 2H)

$0.87(\mathrm{t}, \mathrm{J}=6.8 \mathrm{~Hz}, 3 \mathrm{H}$ )

1.74-1.62 (m, 4H)

${ }^{13} \mathrm{C} \mathrm{NMR}\left(125 \mathrm{MHz}, \mathrm{CDCl}_{3}\right)$ :

$\delta 212.1$

34.8

25.2

14.2

150.8

31.9

24.2

12.1

110.7

31.8

22.8

63.1

30.1

20.3

58.1

28.6

18.2

HRMS (ESI) calculated for $\mathrm{C}_{24} \mathrm{H}_{48} \mathrm{O}_{2} \mathrm{SiNa}[\mathrm{M}+\mathrm{Na}]^{+}: 419.3321$, found: 419.3313

TLC: $\mathrm{Rf}=0.3\left(30 \% \mathrm{CH}_{2} \mathrm{Cl}_{2}\right.$ in hexanes $)$ 

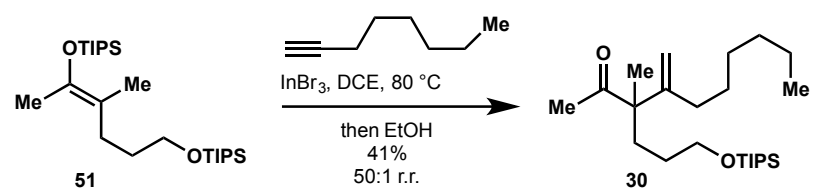

Ketone 30. Prepared according to "General procedure for the alkenylation of silyl enol ethers" from silyl enol ether 51 (ratio of tetra- and disubstituted isomers 9:1) and 1-octyne. The reaction was performed in solution on a $0.25 \mathrm{mmol}$ scale with 0.1 equiv of $\mathrm{InBr}_{3}$. The reaction mixture was heated to $80^{\circ} \mathrm{C}$ for $72 \mathrm{~h}$. The product was isolated by flash chromatography (elution with $20-40 \%$ DCM in hexanes). The alkenylation proceeded in $41 \%$ yield $(0.10 \mathrm{mmol}, 41 \mathrm{mg}$ of ketone $\mathbf{3 0}$ obtained, $>20: 1$ r.r. $)$.

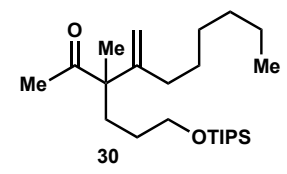

Ketone 30

${ }^{1} \mathrm{H}$ NMR $\left(500 \mathrm{MHz}, \mathrm{CDCl}_{3}\right)$ :

$\delta 5.07(\mathrm{~s}, 1 \mathrm{H})$

1.33-1.22 (m, 7H)

$5.05(\mathrm{~s}, 1 \mathrm{H})$

$1.19(\mathrm{~s}, 3 \mathrm{H})$

$3.67(\mathrm{t}, \mathrm{J}=6.4 \mathrm{~Hz}, 2 \mathrm{H})$

1.12-1.01 (m, 21H)

$2.03(\mathrm{~s}, 3 \mathrm{H})$

$0.88(\mathrm{t}, \mathrm{J}=6.9 \mathrm{~Hz}, 3 \mathrm{H})$

1.87-1.69 $(\mathrm{m}, 4 \mathrm{H})$

$1.46-1.41(\mathrm{~m}, 2 \mathrm{H})$

$1.40-1.34(\mathrm{~m}, 1 \mathrm{H})$

${ }^{13} \mathrm{C} \mathrm{NMR}\left(125 \mathrm{MHz}, \mathrm{CDCl}_{3}\right)$ :

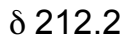

32.4

27.9

14.2

151.0

31.9

25.2

12.1

110.8

31.0

22.8

63.8

29.4

20.2

57.7

28.4

18.2

HRMS (ESI) calculated for $\mathrm{C}_{24} \mathrm{H}_{48} \mathrm{O}_{2} \mathrm{SiNa}[\mathrm{M}+\mathrm{Na}]^{+}: 419.3321$, found: 419.3306

TLC: $\mathrm{Rf}=0.3\left(30 \% \mathrm{CH}_{2} \mathrm{Cl}_{2}\right.$ in hexanes $)$ 


\section{Preparation of starting materials}

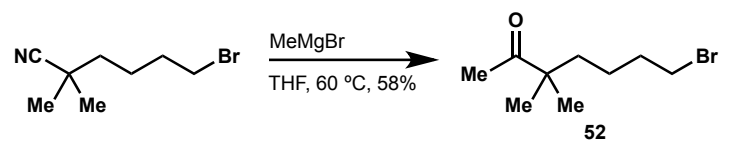

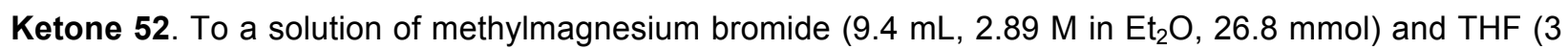
$\mathrm{mL}$ ) in a $25 \mathrm{~mL}$ Schlenk flask was added 6-bromo-2,2-dimethylhexanenitrile $(0.46 \mathrm{~mL}, 2.68 \mathrm{mmol})$ as a solution in THF $(3 \mathrm{~mL})$. The reaction mixture was heated to $60^{\circ} \mathrm{C}$. While heating, $\mathrm{Et}_{2} \mathrm{O}$ was removed under positive pressure of nitrogen. After $16 \mathrm{~h}$, the reaction mixture was diluted with THF ( $5 \mathrm{~mL})$ and cooled to $0{ }^{\circ} \mathrm{C}$. While stirring vigorously, excess methylmagnesium bromide was carefully quenched by the slow addition of $\mathrm{NH}_{4} \mathrm{Cl}(8 \mathrm{~mL})$. The mixture was extracted with $\mathrm{Et}_{2} \mathrm{O}$, and the organic phase was washed with water then brine, dried over anhydrous sodium sulfate, and concentrated under reduced pressure. Purification by flash chromatography (gradient elution 0-3\% EtOAc in hexanes) afforded 342 $\mathrm{mg}(1.55 \mathrm{mmol}, 58 \%)$ of ketone $\mathbf{5 2}$ as a colorless oil.

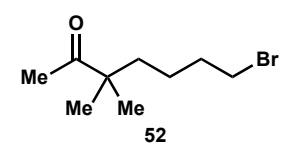

\section{Ketone 52}

${ }^{1} \mathrm{H}$ NMR $\left(500 \mathrm{MHz}, \mathrm{CDCl}_{3}\right)$ :

$\delta 3.39(\mathrm{t}, \mathrm{J}=6.8 \mathrm{~Hz}, 2 \mathrm{H})$

$2.12(\mathrm{~s}, 3 \mathrm{H})$

$1.87-1.80(\mathrm{~m}, 2 \mathrm{H})$

$1.53-1.51(\mathrm{~m}, 2 \mathrm{H})$

$1.35-1.31(\mathrm{~m}, 2 \mathrm{H})$

$1.12(2,6 \mathrm{H})$

${ }^{13} \mathrm{C} \mathrm{NMR}\left(125 \mathrm{MHz}, \mathrm{CDCl}_{3}\right)$ :

ठ $214.0 \quad 33.6 \quad 24.5$

$\begin{array}{lll}47.8 & 33.3 & 23.5\end{array}$

$39.0 \quad 25.3$

HRMS (ESI) calculated for $\mathrm{C}_{9} \mathrm{H}_{17} \mathrm{OBrNa}[\mathrm{M}+\mathrm{Na}]^{+}: 243.0360$, found: 243.0367 .

TLC: $\mathrm{Rf}=0.4(15 \%$ EtOAc in hexanes) 


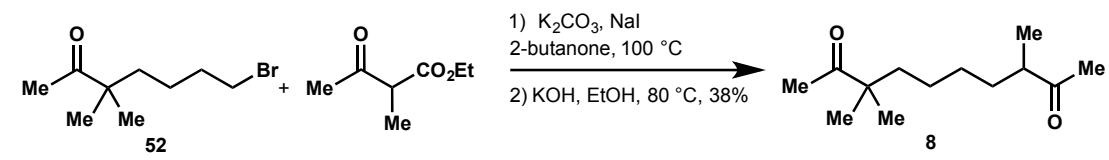

Diketone 8. Ethyl 2-methyl acetoacetate $(2.76 \mathrm{~mL}, 27.3 \mathrm{mmol})$, ketone $52(1.44 \mathrm{~g}, 6.5 \mathrm{mmol}), \mathrm{K}_{2} \mathrm{CO}_{3}(5.4$ $\mathrm{g}, 39 \mathrm{mmol})$, sodium iodide $(2.9 \mathrm{~g}, 19.5 \mathrm{mmol})$, and 2-butanone $(20 \mathrm{~mL})$ were combined in a round bottom flask and the slurry was refluxed for $20 \mathrm{~h}$. The reaction was cooled to room temperature, filtered through Celite and concentrated under reduced pressure. Isolation by flash chromatography yielded an impure mixture of the diketoester alkylation product. This crude material was dissolved in $\mathrm{MeOH}(25 \mathrm{~mL})$ and potassium hydroxide $(1.02 \mathrm{~g}, 18.2 \mathrm{mmol})$ was added. The reaction was refluxed for $4 \mathrm{~h}$, cooled to room temperature, concentrated, dissolved in water, and acidified with $2 \mathrm{~N} \mathrm{HCl}$. This mixture was extracted with diethyl ether and the combined organic layers were washed with saturated aqueous $\mathrm{NaHCO}_{3}$ and brine and dried over anhydrous sodium sulfate. Purification by flash chromatography (gradient elution 0-5\% EtOAc in hexanes) afforded $596 \mathrm{mg}$ (38\% yield) of diketone 8 as a clear oil.

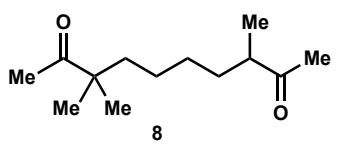

\section{Diketone 8}

${ }^{1} \mathrm{H}$ NMR $\left(600 \mathrm{MHz}, \mathrm{CDCl}_{3}\right)$

$\delta 2.48$ (tq, $\mathrm{J}=7.0,6.9 \mathrm{~Hz}, 1 \mathrm{H}$ )

1.36-1.28 (m, 1H)

$2.12(\mathrm{~s}, 3 \mathrm{H})$

1.26-1.19 (m, 2H)

$2.10(\mathrm{~s}, 3 \mathrm{H})$

$1.17-1.13(\mathrm{~m}, 2 \mathrm{H})$

1.66-1.61 (m, 1H)

$1.09(\mathrm{~s}, 6 \mathrm{H})$

1.50-1.47 (m, 2H)

$1.07(\mathrm{~d}, \mathrm{~J}=7.0 \mathrm{~Hz}, 3 \mathrm{H})$

${ }^{13} \mathrm{C}$ NMR $\left(125 \mathrm{MHz}, \mathrm{CDCl}_{3}\right)$ :

б 214.1

32.7

24.38

212.9

28.1

24.36

47.8

27.9

16.3

47.1

25.1

39.9

24.9

HRMS (ESI) calculated for $\mathrm{C}_{13} \mathrm{H}_{24} \mathrm{O}_{2} \mathrm{Na}[\mathrm{M}+\mathrm{Na}]^{+}: 235.1674$, found: 235.1683 .

TLC: $\mathrm{Rf}=0.27(15 \%$ EtOAc in hexanes $)$ 


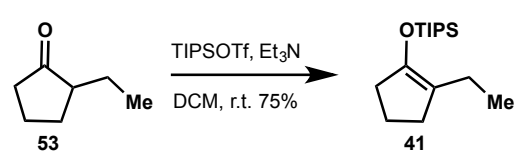

Silyl enol ether 41 . TIPSOTf $(0.91 \mathrm{~mL}, 3.4 \mathrm{mmol})$ was added to a solution of ketone $53^{4}$ (380 $\mathrm{mg}, 3.4$ $\mathrm{mmol})$ in DCM $(10 \mathrm{~mL})$. Triethylamine $(0.95 \mathrm{~mL}, 6.8 \mathrm{mmol})$ was added over 2 minutes. The reaction was stirred at room temperature for $3.5 \mathrm{~h}$, then diluted in hexanes, washed with saturated aqueous $\mathrm{NaHCO}_{3}$ and brine, dried over anhydrous sodium sulfate, and concentrated under reduced pressure to yield silyl enol ether 41. Purification by flash chromatography (elution with hexanes) afforded $0.68 \mathrm{~g}(75 \%$ yield, 10:1 trisubstituted to disubstituted siloxyalkene) of silyl enol ether $\mathbf{4 1}$ as a colorless oil.

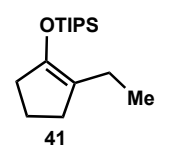

Silyl enol ether $\mathbf{4 1}$

${ }^{1} \mathrm{H}$ NMR $\left(500 \mathrm{MHz}, \mathrm{C}_{6} \mathrm{D}_{6}\right)$ :

$\delta$ 2.33-2.29 (m, 2H)

2.27-2.20 (m, 4H)

1.76-1.70 (m, 2H)

$1.13-1.10(\mathrm{~m}, 21 \mathrm{H})$

$1.03(\mathrm{t}, \mathrm{J}=7.6 \mathrm{~Hz}, 3 \mathrm{H})$

${ }^{13} \mathrm{C}$ NMR (125 MHz, $\left.\mathrm{C}_{6} \mathrm{D}_{6}\right)$ :

$\delta 146.3$

30.8

18.2

117.6

20.3

13.3

34.5

20.0

HRMS (CI) calculated for $\mathrm{C}_{16} \mathrm{H}_{32} \mathrm{OSi}[\mathrm{M}]^{+}:$268.2222, found: 268.2212

TLC: $R f=0.85$ (hexanes) 

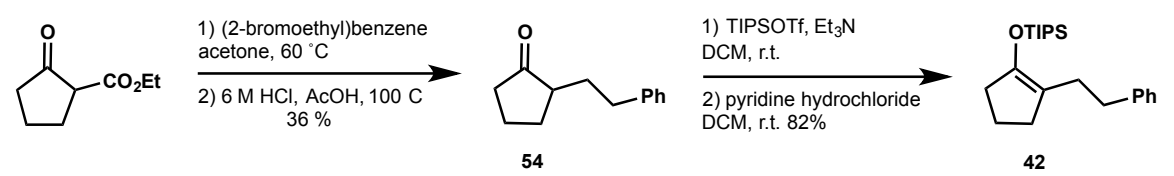

Silyl enol ether 42. Ethyl 2-oxocyclopentanecarboxylate (1.48 mL, $10 \mathrm{mmol})$, (2-bromoethyl)benzene $(5.48 \mathrm{~mL}, 40 \mathrm{mmol}), \mathrm{K}_{2} \mathrm{CO}_{3}(4.15 \mathrm{~g}, 30 \mathrm{mmol})$, acetone $(30 \mathrm{~mL})$ were combined in a round bottom flask and the slurry was refluxed for $21 \mathrm{~h}$. The reaction was cooled to room temperature, filtered through Celite, and concentrated to yield an orange oil. The crude material was dissolved in $\mathrm{AcOH}(12 \mathrm{~mL})$ and $\mathrm{HCl}(6$ $\mathrm{mL}$ of a $6 \mathrm{M}$ solution) was added. The reaction was refluxed for $16 \mathrm{~h}$, cooled to room temperature, diluted with water, and extracted with $\mathrm{Et}_{2} \mathrm{O}$ (three times, $60 \mathrm{~mL}$ combined). The combined organic layers were washed with saturated aqueous $\mathrm{NaHCO}_{3}$ and brine, dried over anhydrous sodium sulfate, and concentrated under reduced pressure. Purification by flash chromatography (gradient elution 1-10\% $\mathrm{Et}_{2} \mathrm{O}$ in hexanes) afforded ketone 54 in a $36 \%$ yield $(0.68 \mathrm{~g}, 3,6 \mathrm{mmol})$ as a clear oil. ${ }^{1} \mathrm{H}$ and ${ }^{13} \mathrm{C}$ NMR data match that provided in the literature. ${ }^{4}$ TIPSOTf $(0.97 \mathrm{~mL}, 3.6 \mathrm{mmol})$ was added to a solution of ketone 54 $(0.68 \mathrm{~g}, 3.6 \mathrm{mmol})$ in $\mathrm{DCM}(10 \mathrm{~mL})$. Triethylamine $(0.65 \mathrm{~mL}, 4.7 \mathrm{mmol})$ was added over 2 minutes. The reaction was stirred at room temperature for $16 \mathrm{~h}$, then diluted in hexanes, washed with saturated aqueous $\mathrm{NaHCO}_{3}$ and brine, dried over anhydrous sodium sulfate, and concentrated under reduced pressure to yield a 1:1 mixture of trisubstituted to disubstituted siloxyalkenes. The crude material was dissolved in DCM (3 mL) and added to a Schlenk flask charged with pyridine hydrochloride (33.5 mg, $0.29 \mathrm{mmol}$ ) and stirred at room temperature for $1 \mathrm{~h}$. The reaction was diluted with hexanes, washed with saturated aqueous $\mathrm{NaHCO}_{3}$ and brine, dried over anhydrous sodium sulfate, and concentrated under reduced pressure. Purification on $\mathrm{Et}_{3} \mathrm{~N}$-treated silica (elution with hexanes) afforded $0.93 \mathrm{~g}(75 \%$ yield, 14:1 trisubstituted to disubstituted siloxyalkene) of silyl enol ether $\mathbf{4 2}$ as a colorless oil.

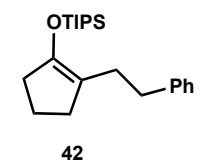

Silyl enol ether $\mathbf{4 2}$

${ }^{1} \mathrm{H}$ NMR (500 MHz, $\left.\mathrm{C}_{6} \mathrm{D}_{6}\right)$ :

$\delta 7.23-7.17(\mathrm{~m}, 4 \mathrm{H})$

2.56-2.52 (m, 2H)

$1.75-1.69(\mathrm{~m}, 2 \mathrm{H})$

7.09-7.05 $(\mathrm{m}, 1 \mathrm{H})$

2.30-2.27 (m, 2H)

1.12-1.06 $(\mathrm{m}, 21 \mathrm{H})$

$2.72(\mathrm{dd}, \mathrm{J}=9.4,6.6 \mathrm{~Hz}, 2 \mathrm{H})$

2.22-2.19 (m, 2H)

${ }^{13} \mathrm{C}$ NMR $\left(125 \mathrm{MHz}, \mathrm{C}_{6} \mathrm{D}_{6}\right)$ :

$\delta 147.5$

126.0

31.4

13.3

143.1

115.6

29.2

128.7

34.7

20.4

128.6

34.4

18.2

HRMS (Cl) calculated for $\mathrm{C}_{22} \mathrm{H}_{37} \mathrm{OSi}[\mathrm{M}+\mathrm{H}]^{+}: 345.2614$, found: 345.2599

TLC: $\mathrm{Rf}=0.6$ (hexanes) 


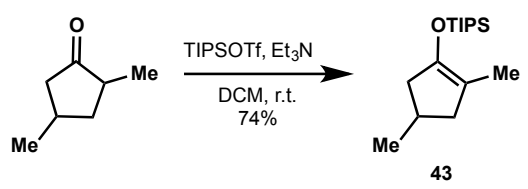

Silyl enol ether 43. TIPSOTf $(1.1 \mathrm{~mL}, 4 \mathrm{mmol})$ was added to a solution of 2,4-dimethylcyclopentanone $(0.5 \mathrm{~mL}, 2.0 \mathrm{mmol})$ in DCM $(12 \mathrm{~mL})$. Triethylamine $(1.0 \mathrm{~mL}, 7.2 \mathrm{mmol})$ was added over 2 minutes. The reaction was stirred at room temperature for $5 \mathrm{~h}$, then diluted in hexanes, washed with saturated aqueous $\mathrm{NaHCO}_{3}$ and brine, dried over anhydrous sodium sulfate, and concentrated under reduced pressure. Purification by flash chromatography of $\mathrm{Et}_{3} \mathrm{~N}$-treated silica gel (elution $1 \% \mathrm{Et}_{3} \mathrm{~N}$ in hexanes) afforded 0.79 $\mathrm{g}(\mathbf{7 4 \%}$ yield $)$ of silyl enol ether $\mathbf{4 3}$ as a colorless oil.

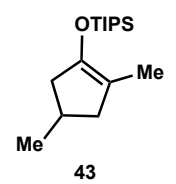

Silyl enol ether $\mathbf{4 3}$

${ }^{1} \mathrm{H}$ NMR $\left(500 \mathrm{MHz}, \mathrm{CDCl}_{3}\right)$ :

$\delta 2.50(\mathrm{dd}, \mathrm{J}=14.0,9.0 \mathrm{~Hz}, 1 \mathrm{H})$

$1.55(\mathrm{~s}, 3 \mathrm{H})$

$2.35(\mathrm{dd}, \mathrm{J}=14.6,8.4 \mathrm{~Hz} \mathrm{1 \textrm {H } )}$

1.16-1.05 $(\mathrm{m}, 21 \mathrm{H})$

2.29-2.21 (m, 1H)

$1.03(\mathrm{~d}, \mathrm{~J}=6.8 \mathrm{~Hz}, 3 \mathrm{H})$

1.98-1.93 $(\mathrm{m}, 1 \mathrm{H})$

1.78-1.76 (m, 1H)

${ }^{13} \mathrm{C}$ NMR $\left(125 \mathrm{MHz}, \mathrm{CDCl}_{3}\right)$ :

$\delta 145.3$

22.5

111.4

18.0

42.4

12.9

42.1

12.0

28.3

HRMS $(\mathrm{Cl})$ calculated for $\mathrm{C}_{16} \mathrm{H}_{32} \mathrm{OSi}[\mathrm{M}]^{+}:$268.2222, found: 268.2223 .

TLC: $\mathrm{Rf}=0.85$ (hexanes) 


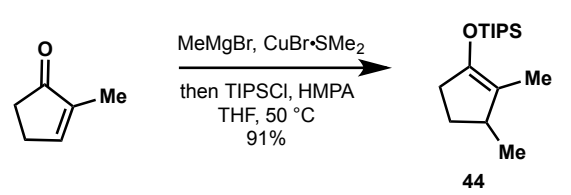

Silyl enol ether 44. A solution of methylmagnesium bromide $(1.74 \mathrm{~mL}$ of a $2.98 \mathrm{M}$ solution in diethyl ether, $5.2 \mathrm{mmol})$ was added to a suspension of $\mathrm{CuBr} \cdot \mathrm{SMe}_{2}(82 \mathrm{mg}, 0.40 \mathrm{mmol})$ in THF $(4 \mathrm{~mL})$ at $-35{ }^{\circ} \mathrm{C}$ over the course of $5 \mathrm{~min}$. The resulting solution was stirred for $20 \mathrm{~min}$ and cooled to $-45^{\circ} \mathrm{C}$. 2-Methyl-2cyclopenten-1-one $(0.39 \mathrm{~mL}, 4.0 \mathrm{mmol})$ was added to the reaction mixture over the course of $30 \mathrm{~min}$. The resulting solution was stirred for $40 \mathrm{~min}$ at $-45{ }^{\circ} \mathrm{C}$ and treated with TIPSCI (1.96 mL, $\left.9.2 \mathrm{mmol}\right)$. The reaction mixture was warmed up to room temperature and treated with HMPA (3.2 mL, $18.4 \mathrm{mmol})$. The resulting suspension was heated to $50{ }^{\circ} \mathrm{C}$ for $17 \mathrm{~h}$ and quenched with a $3: 1(\mathrm{v} / \mathrm{v})$ mixture of saturated aqueous $\mathrm{NH}_{4} \mathrm{Cl}$ and $28 \%(\mathrm{v} / \mathrm{v})$ aqueous $\mathrm{NH}_{3}$. The resulting solution was diluted with hexanes. The layers were separated, and the organic layer was washed with water, then brine, dried over anhydrous sodium sulfate, and concentrated under reduced pressure. Purification by flash chromatography on $\mathrm{Et}_{3} \mathrm{~N}^{-}$treated silica gel (elution with $1 \% \mathrm{Et}_{3} \mathrm{~N}$ in hexanes) afforded $0.98 \mathrm{~g}$ (91\% yield) of silyl enol ether 44 as a colorless oil.

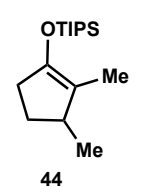

Silyl enol ether $\mathbf{4 4}$

${ }^{1} \mathrm{H}$ NMR $\left(500 \mathrm{MHz}, \mathrm{CDCl}_{3}\right)$ :

$\delta$ 2.47-2.43 $(\mathrm{m}, 1 \mathrm{H})$

1.34-1.27 (m, 1H)

2.32-2.26 (m, 2H)

1.15-1.08 $(\mathrm{m}, 3 \mathrm{H})$

2.05-1.99 (m, 1H)

$1.08(\mathrm{~d}, \mathrm{~J}=6.0 \mathrm{~Hz}, 18 \mathrm{H})$

$1.53(\mathrm{~s}, 3 \mathrm{H})$

$0.97(\mathrm{~d}, \mathrm{~J}=6.8 \mathrm{~Hz}, 3 \mathrm{H})$

${ }^{13} \mathrm{C}$ NMR (125 MHz, $\left.\mathrm{CDCl}_{3}\right)$ :

$\delta 146.7$

20.2

117.0

18.1

39.4

13.0

32.9

10.2

29.5

HRMS (Cl) calculated for $\mathrm{C}_{16} \mathrm{H}_{32} \mathrm{OSi}[\mathrm{M}]^{+}: 268.2222$, found: 268.2234 .

TLC: $\mathrm{Rf}=0.85$ (hexanes) 


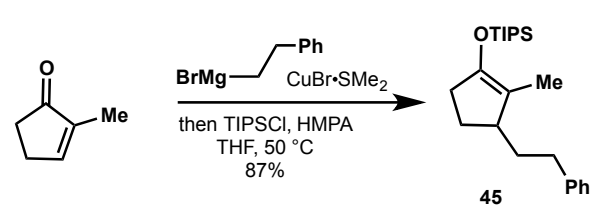

Silyl enol ether 45. A solution of phenethylmagnesium bromide $(2.6 \mathrm{~mL}$ of a $2.0 \mathrm{M}$ solution in THF, 5.2 $\mathrm{mmol}$, prepared from (1-bromoethyl)benzene) was added to a suspension of $\mathrm{CuBr}^{-\mathrm{SMe}_{2}}$ (82 $\mathrm{mg}, 0.40$ $\mathrm{mmol})$ in THF $(4 \mathrm{~mL})$ at $-35{ }^{\circ} \mathrm{C}$ over the course of $5 \mathrm{~min}$. The resulting solution was stirred for $20 \mathrm{~min}$ and cooled to $-45{ }^{\circ} \mathrm{C}$. 2-Methyl-2-cyclopenten-1-one $(0.39 \mathrm{~mL}, 4.0 \mathrm{mmol})$ was added to the reaction mixture over the course of $30 \mathrm{~min}$. The resulting solution was stirred for $40 \mathrm{~min}$ at $-45{ }^{\circ} \mathrm{C}$ and treated with TIPSCI (1.96 mL, $9.2 \mathrm{mmol})$. The reaction mixture was warmed up to room temperature and treated with HMPA (3.2 mL, $18.4 \mathrm{mmol})$. The resulting suspension was heated to $50{ }^{\circ} \mathrm{C}$ for $17 \mathrm{~h}$ and quenched with a 3:1 (v/v) mixture of saturated aqueous $\mathrm{NH}_{4} \mathrm{Cl}$ and $28 \%(\mathrm{v} / \mathrm{v})$ aqueous $\mathrm{NH}_{3}$. The resulting solution was diluted with hexanes. The layers were separated, and the organic layer was washed with water, then brine, dried over anhydrous sodium sulfate, and concentrated under reduced pressure. Purification by flash chromatography on $\mathrm{Et}_{3} \mathrm{~N}$-treated silica gel (elution with $1 \% \mathrm{Et}_{3} \mathrm{~N}$ in hexanes) afforded $1.25 \mathrm{~g}(87 \%$ yield) of silyl enol ether $\mathbf{4 5}$ as a colorless oil.

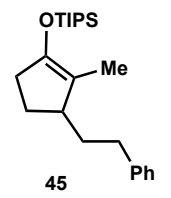

Silyl enol ether $\mathbf{4 5}$

${ }^{1} \mathrm{H}$ NMR $\left(500 \mathrm{MHz} ; \mathrm{CDCl}_{3}\right)$ :

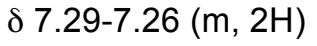

1.93-1.86 (m, 1H)

7.20-7.16 $(\mathrm{m}, 3 \mathrm{H})$

$1.54(\mathrm{~s}, 3 \mathrm{H})$

2.68-2.62 (m, 1H)

1.52-1.47 (m, 1H)

2.55-2.46 (m, 1H)

1.45-1.37 (m, 1H)

2.47-2.43 $(\mathrm{m}, 1 \mathrm{H})$

1.17-1.11 (m, 3H)

2.35-2.30 (m, 2H)

$1.09(\mathrm{~d}, \mathrm{~J}=5.8 \mathrm{~Hz}, 18 \mathrm{H})$

2.07-2.02 (m, 1H)

${ }^{13} \mathrm{C}$ NMR $\left(125 \mathrm{MHz}, \mathrm{CDCl}_{3}\right)$ :

$\delta 147.3$

143.2

128.5

128.4

125.7
115.5

44.5

36.5

33.4

33.0
26.7

18.1

13.0

10.5

HRMS (Cl) calculated for $\mathrm{C}_{23} \mathrm{H}_{39} \mathrm{OSi}[\mathrm{M}+\mathrm{H}]^{+}: 359.2770$, found: 359.2777

TLC: $\mathrm{Rf}=0.65$ (hexanes) 


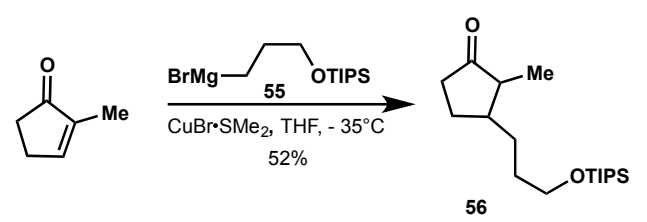

Ketone 56. A solution of Grignard 55 (23.6 mL of a $0.22 \mathrm{M}$ solution in THF, $5.2 \mathrm{mmol}$, prepared from (3bromopropoxy)triisopropylsilane ${ }^{5}$ ) was added to a suspension of $\mathrm{CuBr} \cdot \mathrm{SMe}_{2}(82 \mathrm{mg}, 0.40 \mathrm{mmol})$ in THF $(1 \mathrm{~mL})$ at $-35{ }^{\circ} \mathrm{C}$ over the course of $5 \mathrm{~min}$. The resulting solution was stirred for $20 \mathrm{~min}$ and cooled to $45{ }^{\circ} \mathrm{C}$. 2-Methyl-2-cyclopenten-1-one $(0.39 \mathrm{~mL}, 4.0 \mathrm{mmol})$ was added to the reaction mixture over the course of $30 \mathrm{~min}$. The resulting solution was stirred for $15 \mathrm{~min}$ at $-45^{\circ} \mathrm{C}$ and quenched with degassed saturated aqueous $\mathrm{NH}_{3} \mathrm{Cl}$. The resulting solution was diluted with diethyl ether, the layers were separated, and the organic layer was washed with water, then brine, dried over anhydrous sodium sulfate, and concentrated under reduced pressure. Purification by flash chromatography on silica gel (gradient elution with 1-6\% EtOAc in hexanes) and then heating to $50{ }^{\circ} \mathrm{C}$ under vacuum (ca. 0.1 torr) to remove TIPSOH afforded $0.65 \mathrm{~g}$ ( $52 \%$ yield) of ketone $\mathbf{5 6}$ as a colorless oil (1.5:1 d.r., contaminated with $5 \%$ TIPSOH).

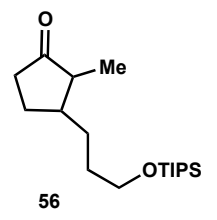

\section{Ketone 56}

${ }^{1} \mathrm{H}$ NMR $\left(500 \mathrm{MHz}, \mathrm{C}_{6} \mathrm{D}_{6}\right)$ :

$\delta 3.59(\mathrm{t}, \mathrm{J}=6.2 \mathrm{~Hz}, 2 \mathrm{H})$

1.47-1.40 (m, 1H)

$3.55(\mathrm{t}, \mathrm{J}=6.2 \mathrm{~Hz}, 1.3 \mathrm{H})$

1.39-1.18 $(\mathrm{m}, 4.8 \mathrm{H})$

2.03-1.89 (m, 2.4H)

1.15-1.05 (m, 36.7H)

$1.85-1.78(\mathrm{~m}, 0.7 \mathrm{H})$

$1.03(\mathrm{dd}, \mathrm{J}=6.6,0.83 \mathrm{~Hz}, 3 \mathrm{H})$

1.77-1.69 (m, 1.7H)

0.88 (dd, J = 7.47, $0.82 \mathrm{~Hz}, 2 \mathrm{H}$ )

1.67-1.62 (m, 1H)

1.61-1.48 (m, 2.4H)

${ }^{13} \mathrm{C}$ NMR $\left(125 \mathrm{MHz}, \mathrm{C}_{6} \mathrm{D}_{6}\right)$ :

$\delta 218.7$

44.6

30.8

13.0

217.9

39.9

27.3

12.39

63.74

37.1

25.8

12.37

63.66

36.0

25.7

9.9

50.3

31.6

18.33

46.7

31.0

18.31

HRMS (Cl) calculated for $\mathrm{C}_{18} \mathrm{H}_{40} \mathrm{NO}_{2} \mathrm{Si}\left[\mathrm{M}+\mathrm{NH}_{4}\right]^{+}: 330.2828$, found: 330.2828 .

TLC: $\mathrm{Rf}=0.4(5 \%$ EtOAc in hexanes $)$ 


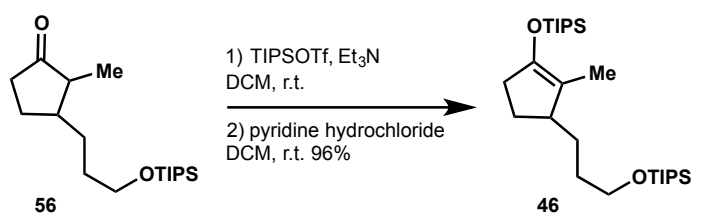

Silyl enol ether 46. TIPSOTf $(0.62 \mathrm{~mL}, 2.3 \mathrm{mmol})$ was added to a solution of ketone $56(0.65 \mathrm{~g}, 2.1$ $\mathrm{mmol})$ in DCM $(6 \mathrm{~mL})$. Triethylamine $(0.52 \mathrm{~mL}, 3.7 \mathrm{mmol})$ was added over 2 minutes. The reaction was stirred at room temperature for $17 \mathrm{~h}$, then diluted in hexanes, washed with saturated aqueous $\mathrm{NaHCO}_{3}$ and brine, dried over anhydrous sodium sulfate, and concentrated under reduced pressure to yield a 1:1 mixture of trisubstituted to disubstituted siloxyalkenes. The crude material was dissolved in DCM (2 $\mathrm{mL})$ and added to a Schlenk flask charged with pyridine hydrochloride $(0.012 \mathrm{~g}, 0.1 \mathrm{mmol})$ and stirred at room temperature for $1 \mathrm{~h}$. The reaction was quenched with $1 \mathrm{~mL} \mathrm{Et}_{3} \mathrm{~N}$, diluted with hexanes, washed with saturated aqueous $\mathrm{NaHCO}_{3}$ and brine, dried over anhydrous sodium sulfate, and concentrated under reduced pressure. Purification through a neutral alumina plug (elution with $1 \% \mathrm{Et}_{3} \mathrm{~N}$ in hexanes) then heating to $50{ }^{\circ} \mathrm{C}$ under vacuum (ca. 0.1 torr) to remove TIPSOH afforded $0.94 \mathrm{~g}$ ( $96 \%$ yield) of silyl enol ether $\mathbf{4 6}$ as a colorless oil.

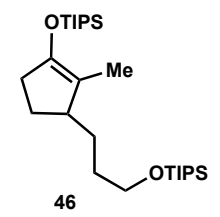

Silyl enol ether 46

${ }^{1} \mathrm{H}$ NMR (500 MHz, $\left.\mathrm{C}_{6} \mathrm{D}_{6}\right)$ :

$\delta 3.68(\mathrm{t}, \mathrm{J}=6.7 \mathrm{~Hz}, 2 \mathrm{H})$

$1.58-1.50(\mathrm{~m}, 1 \mathrm{H})$

2.50-2.44 (m, 1H)

$1.49-1.40(\mathrm{~m}, 1 \mathrm{H})$

2.36-2.24 (m, 2H)

1.32-1.22 (m, 1H)

1.99-1.92 $(\mathrm{m}, 1 \mathrm{H})$

1.16-1.08 (m, 42H)

1.77-1.62 (m, 5H)

${ }^{13} \mathrm{C}$ NMR (125 MHz, $\left.\mathrm{C}_{6} \mathrm{D}_{6}\right)$ :

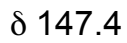

30.9

13.3

115.4

30.7

12.4

64.1

26.9

10.7

44.8

18.4

33.4

18.2

HRMS (Cl) calculated for $\mathrm{C}_{27} \mathrm{H}_{57} \mathrm{O}_{2} \mathrm{Si}_{2}[\mathrm{M}+\mathrm{H}]^{+}:$469.3897, found: 469.3905 .

TLC: $\mathrm{Rf}=0.5$ (hexanes) 


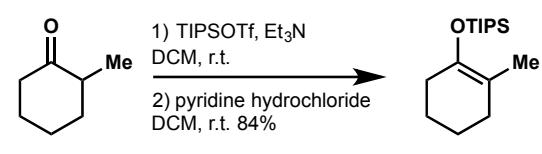

38

Silyl enol ether 38. TIPSOTf $(3.23 \mathrm{~mL}, 12 \mathrm{mmol})$ was added to a solution of 2-methylcyclohexanone $(1.46 \mathrm{~mL}, 12 \mathrm{mmol})$ in DCM $(30 \mathrm{~mL})$. Triethylamine $(2.17 \mathrm{~mL}, 15.6 \mathrm{mmol})$ was added over 2 minutes. The reaction was stirred at room temperature for $5.5 \mathrm{~h}$, then diluted in hexanes, washed with saturated aqueous $\mathrm{NaHCO}_{3}$ and brine, dried over anhydrous sodium sulfate, and concentrated under reduced pressure to yield a 2:1 mixture of trisubstituted to disubstituted siloxyalkenes. The crude material was dissolved in DCM (12 $\mathrm{mL})$ and added to a Schlenk flask charged with pyridine hydrochloride $(0.127 \mathrm{~g}, 1.1$ $\mathrm{mmol}$ ) and stirred at room temperature for $1.5 \mathrm{~h}$. The reaction was diluted with hexanes, washed with saturated aqueous $\mathrm{NaHCO}_{3}$ and brine, dried over anhydrous sodium sulfate, and concentrated under reduced pressure. Purification on $\mathrm{Et}_{3} \mathrm{~N}$-treated silica (elution with hexanes) afforded $2.7 \mathrm{~g}$ (84\% yield, 13:1 trisubstituted to disubstituted siloxyalkenes) of silyl enol ether $\mathbf{3 8}$ as a colorless oil.

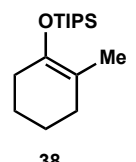

Silyl enol ether 38

${ }^{1} \mathrm{H}$ NMR $\left(500 \mathrm{MHz}, \mathrm{C}_{6} \mathrm{D}_{6}\right)$ :

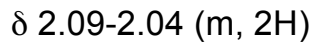

1.94-1.91 (m, 2H)

1.75 (s, 3H)

1.58-1.53 (m, 2H)

1.49-1.45 (m, 2H)

1.16-1.13 $(\mathrm{m}, 21 \mathrm{H})$

${ }^{13} \mathrm{C}$ NMR $\left(125 \mathrm{MHz}, \mathrm{CDCl}_{3}\right)$ :

ठ 143.4

24.1

17.9

111.0

23.1

16.7

30.6

18.3

13.4

HRMS (CI) calculated for $\mathrm{C}_{16} \mathrm{H}_{32} \mathrm{OSi}[\mathrm{M}]^{+}:$268.222, found: 268.2233 .

TLC: $R f=0.85$ (hexanes) 


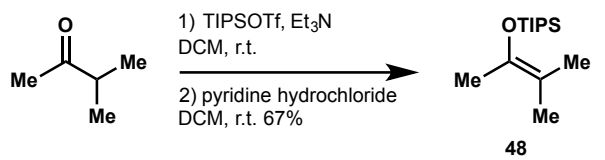

Silyl enol ether 48 . TIPSOTf $(3.2 \mathrm{~mL}, 12 \mathrm{mmol})$ was added to a solution of 3-methyl-2-butanone $(1.3 \mathrm{~mL}$, $12 \mathrm{mmol})$ in DCM (36 mL). Triethylamine $(2.2 \mathrm{~mL}, 16 \mathrm{mmol})$ was added over 2 minutes. The reaction was stirred at room temperature for $17 \mathrm{~h}$, then diluted in hexanes, washed with saturated aqueous $\mathrm{NaHCO}_{3}$ and brine, dried over anhydrous sodium sulfate, and concentrated under reduced pressure to yield exclusively the monosubstituted siloxyalkene. The crude material was dissolved in DCM $(10 \mathrm{~mL})$, added to a Schlenk flask charged with pyridine hydrochloride $(0.139 \mathrm{~g}, 1.2 \mathrm{mmol})$, and stirred at room temperature for $1 \mathrm{~h}$. The reaction was quenched with $1 \mathrm{~mL}$ of triethylamine, diluted with hexanes, washed with saturated aqueous $\mathrm{NaHCO}_{3}$ and brine, dried over anhydrous sodium sulfate, and concentrated under reduced pressure. Purification through a neutral alumina plug (elution with $1 \% \mathrm{Et}_{3} \mathrm{~N}$ in hexanes) afforded $1.95 \mathrm{~g} \mathrm{(67 \%} \mathrm{yield,} \mathrm{7:1} \mathrm{mixture} \mathrm{of} \mathrm{trisubstituted} \mathrm{to} \mathrm{disubstituted} \mathrm{siloxyalkenes)} \mathrm{of} \mathrm{silyl} \mathrm{enol} \mathrm{ether} \mathbf{4 8}$ as a colorless oil.

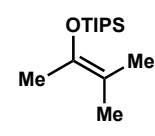

48

Silyl enol ether $\mathbf{4 8}$

${ }^{1} \mathrm{H}$ NMR (500 MHz, $\left.\mathrm{CDCl}_{3}\right)$ :

$\delta 1.83(\mathrm{~s}, 3 \mathrm{H})$

$1.64(\mathrm{~s}, 3 \mathrm{H})$

$1.58(\mathrm{~s}, 3 \mathrm{H})$

1.18-1.05 (m, 21H)

${ }^{13} \mathrm{C}$ NMR (125 MHz, $\mathrm{CDCl}_{3}$ ):

$\delta 140.7$

18.2

108.5

17.8

19.2

13.4

18.6

HRMS (Cl) calculated for $\mathrm{C}_{14} \mathrm{H}_{31} \mathrm{OSi}[\mathrm{M}+\mathrm{H}]^{+}: 243.2144$, found: 243.2143 .

TLC: $\mathrm{Rf}=0.85$ (hexanes) 


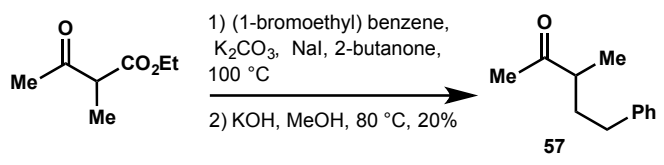

Ketone 57. Ethyl 2-methyl acetoacetate $(8.5 \mathrm{~mL}, 60 \mathrm{mmol})$, (1-bromoethyl)benzene $(2.7 \mathrm{~mL}, 20 \mathrm{mmol})$, $\mathrm{K}_{2} \mathrm{CO}_{3}(16.6 \mathrm{~g}, 120 \mathrm{mmol})$, sodium iodide $(3.0 \mathrm{~g}, 20 \mathrm{mmol})$, and 2-butanone $(60 \mathrm{~mL})$ were combined in a round bottom flask and the slurry was refluxed for $18 \mathrm{~h}$. The reaction was cooled to room temperature, filtered through Celite, and concentrated to yield an orange oil. The crude material was dissolved in $\mathrm{MeOH}(60 \mathrm{~mL})$ and potassium hydroxide $(6.7 \mathrm{~g}, 120 \mathrm{mmol})$ was added. The reaction was refluxed for $2 \mathrm{~h}$, cooled to room temperature, concentrated, dissolved in water, and acidified with $2 \mathrm{~N} \mathrm{HCl}$. This mixture was extracted with diethyl ether and the combined organic layers were washed with saturated aqueous $\mathrm{NaHCO}_{3}$ and brine, dried over anhydrous sodium sulfate, and concentrated under reduced pressure. Purification by flash chromatography (gradient elution 2-3\% $\mathrm{Et}_{2} \mathrm{O}$ in hexanes) followed by vacuum distillation afforded $0.70 \mathrm{~g}$ ( $20 \%$ yield) of ketone $\mathbf{5 7}$ as a clear oil.

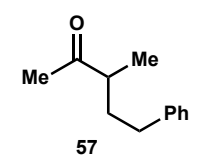

\section{Ketone $\mathbf{5 7}$}

${ }^{1} \mathrm{H}$ NMR $\left(500 \mathrm{MHz}, \mathrm{CDCl}_{3}\right)$ :

$\delta$ 7.30-7.27 (m, 2H)

2.01 (ddt, $\mathrm{J}=13.7,9.1,6.9 \mathrm{~Hz}, 1 \mathrm{H}$ )

7.21-7.16 (m, 3H) $1.64(\mathrm{ddt}, \mathrm{J}=13.7,9.0,6.8 \mathrm{~Hz}, 1 \mathrm{H})$

2.59 (ddd, J = 9.3, 6.7, $2.7 \mathrm{~Hz}, 2 \mathrm{H}$ ) $1.14(\mathrm{~d}, \mathrm{~J}=7.0 \mathrm{~Hz}, 3 \mathrm{H})$

2.56-2.50 (m, 1H)

$2.13(\mathrm{~s}, 3 \mathrm{H})$

${ }^{13} \mathrm{C}$ NMR $\left(125 \mathrm{MHz}, \mathrm{CDCl}_{3}\right)$ :

$\delta 212.6$

46.6

141.8

HRMS (ESI) calculated for $\mathrm{C}_{12} \mathrm{H}_{16} \mathrm{ONa}[\mathrm{M}+\mathrm{Na}]^{+}:$199.1099, found: 199.1100 .

TLC: $\mathrm{Rf}=0.25$ (5\% EtOAc in hexanes) 


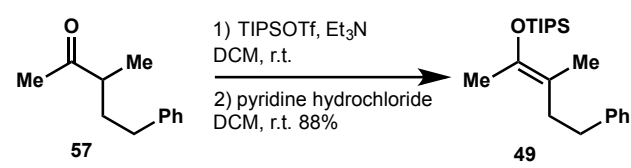

Silyl enol ether 49 . TIPSOTf $(1.2 \mathrm{~mL}, 4.4 \mathrm{mmol})$ was added to a solution of ketone $\mathbf{5 7}(0.70 \mathrm{~g}, 4.0 \mathrm{mmol})$ in DCM (12 mL). Triethylamine $(1.0 \mathrm{~mL}, 7.2 \mathrm{mmol})$ was added over 2 minutes. The reaction was stirred at room temperature for $4 \mathrm{~h}$, then diluted in hexanes, washed with saturated aqueous $\mathrm{NaHCO}_{3}$ and brine, dried over anhydrous sodium sulfate, and concentrated under reduced pressure to yield exclusively the monosubstituted siloxyalkene. The crude material was dissolved in DCM (4 mL) and added to a Schlenk flask charged with pyridine hydrochloride $(23 \mathrm{mg}, 0.2 \mathrm{mmol})$ and stirred at room temperature for $1 \mathrm{~h}$. The reaction was quenched with $1 \mathrm{~mL} \mathrm{Et}{ }_{3} \mathrm{~N}$, diluted with hexanes, washed with saturated aqueous $\mathrm{NaHCO}_{3}$ and brine, dried over anhydrous sodium sulfate, and concentrated under reduced pressure. Purification through a neutral alumina plug (elution with $1 \% \mathrm{Et}_{3} \mathrm{~N}$ in hexanes) then heating to $50{ }^{\circ} \mathrm{C}$ under vacuum (ca. 0.1 torr) to remove TIPSPOH afforded $1.17 \mathrm{~g}$ (88\% yield, $1: 1.7$ mixture of $E$ and $Z$ isomers, $7: 1$ trisubstituted to monosubstituted siloxyalkene) of silyl enol ether $\mathbf{4 9}$ as a colorless oil.

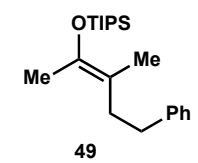

Silyl enol ether $\mathbf{4 9}$

${ }^{1} \mathrm{H}$ NMR $\left(500 \mathrm{MHz}, \mathrm{C}_{6} \mathrm{D}_{6}\right)$ :

$\delta 7.27-7.25(\mathrm{~m}, 1.2 \mathrm{H})$

$1.77(\mathrm{~s}, 1.8 \mathrm{H})$

7.23-7.17 (m, 3.6H)

$1.68(\mathrm{~s}, 3 \mathrm{H})$

7.10-7.07 (m, 3.2H)

$1.56(\mathrm{~s}, 1.8 \mathrm{H})$

$2.76(\mathrm{dd}, \mathrm{J}=9.8,6.6 \mathrm{~Hz}, 1.2 \mathrm{H}$ )

1.13-1.08 (m, 30.6H)

2.63-2.55 (m, 3.2H)

1.05-0.95 (m, 3H)

$2.23(\mathrm{dd}, \mathrm{J}=8.3,6.4 \mathrm{~Hz}, 2 \mathrm{H})$

$1.79(\mathrm{~s}, 3 \mathrm{H})$

${ }^{13} \mathrm{C}$ NMR $\left(125 \mathrm{MHz}, \mathrm{C}_{6} \mathrm{D}_{6}\right)$ :

б 143.3

128.62

36.0

18.43

142.7

128.59

35.2

18.38

142.3

126.04

34.8

17.1

141.4

125.99

34.1

16.0

128.9

111.7

19.5

13.74

128.8

111.6

18.8

13.66

HRMS (Cl) calculated for $\mathrm{C}_{21} \mathrm{H}_{37} \mathrm{OSi}[\mathrm{M}+\mathrm{H}]^{+}: 333.2614$, found: 333.2610 .

TLC: $R f=0.65$ (hexanes) 


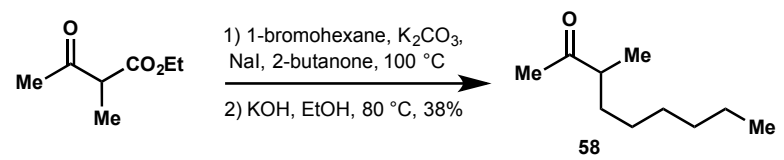

Ketone 58. Ethyl 2-methyl acetoacetate $(4.2 \mathrm{~mL}, 30 \mathrm{mmol}), 1$-bromohexane $(1.4 \mathrm{~mL}, 10 \mathrm{mmol}), \mathrm{K}_{2} \mathrm{CO}_{3}$ $(8.3 \mathrm{~g}, 60 \mathrm{mmol})$, sodium iodide $(3.0 \mathrm{~g}, 20 \mathrm{mmol})$, and 2-butanone $(30 \mathrm{~mL})$ were combined in a round bottom flask and the slurry was refluxed for $18 \mathrm{~h}$. The reaction was cooled to room temperature, filtered through Celite, and concentrated to yield an orange oil. The crude material was dissolved in $\mathrm{EtOH} \mathrm{(30}$ $\mathrm{mL}$ ) and potassium hydroxide $(3.4 \mathrm{~g}, 60 \mathrm{mmol}$ ) was added. The reaction was refluxed for $1 \mathrm{~h}$, cooled to room temperature, concentrated, dissolved in water, and acidified with $2 \mathrm{~N} \mathrm{HCl}$. This mixture was extracted with diethyl ether and the combined organic layers were washed with saturated aqueous $\mathrm{NaHCO}_{3}$ and brine, dried over anhydrous sodium sulfate, and concentrated under reduced pressure. Purification by flash chromatography (gradient elution $2-3 \% \mathrm{Et}_{2} \mathrm{O}$ in hexanes) afforded $0.59 \mathrm{~g}$ (38\% yield) of ketone $\mathbf{5 8}$ as a clear oil.

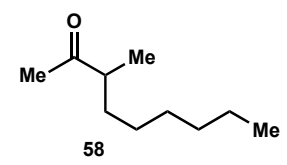

\section{Ketone 58}

${ }^{1} \mathrm{H}$ NMR $\left(500 \mathrm{MHz}, \mathrm{CDCl}_{3}\right)$ :

$\delta$ 2.53-2.46 (m, 1H)

$2.12(\mathrm{~s}, 3 \mathrm{H})$

$1.67-1.59(\mathrm{~m}, 1 \mathrm{H})$

$1.37-1.18(\mathrm{~m}, 9 \mathrm{H})$

$1.07(\mathrm{~d}, \mathrm{~J}=7.0,3 \mathrm{H})$

$0.87(\mathrm{t}, \mathrm{J}=7.0 \mathrm{~Hz}, 3 \mathrm{H}$ )

${ }^{13} \mathrm{C}$ NMR $\left(125 \mathrm{MHz}, \mathrm{CDCl}_{3}\right)$ :

ठ 213.1

HRMS $(\mathrm{Cl})$ calculated for $\mathrm{C}_{10} \mathrm{H}_{24} \mathrm{NO}\left[\mathrm{M}+\mathrm{NH}_{4}\right]^{+}: 174.1858$, found: 174.1854 .

TLC: $\mathrm{Rf}=0.5(10 \%$ EtOAc in hexanes $)$ 

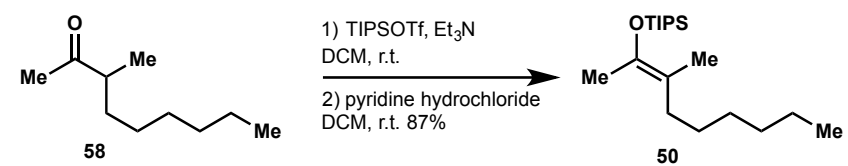

Silyl enol ether 50. TIPSOTf $(1.1 \mathrm{~mL}, 4.2 \mathrm{mmol})$ was added to a solution of ketone $\mathbf{5 8}(0.59 \mathrm{~g}, 3.8 \mathrm{mmol})$ in DCM (12 mL). Triethylamine $(0.95 \mathrm{~mL}, 6.8 \mathrm{mmol})$ was added over 2 minutes. The reaction was stirred at room temperature for $15 \mathrm{~h}$, then diluted in hexanes, washed with saturated aqueous $\mathrm{NaHCO}_{3}$ and brine, dried over anhydrous sodium sulfate, and concentrated under reduced pressure to yield exclusively the monosubstituted silyl enol ether. The crude material was dissolved in DCM (4 mL) and added to a Schlenk flask charged with pyridine hydrochloride $(0.023 \mathrm{~g}, 0.2 \mathrm{mmol})$ and stirred at room temperature for $1 \mathrm{~h}$. The reaction was quenched with $1 \mathrm{~mL} \mathrm{Et}_{3} \mathrm{~N}$, diluted with hexanes, washed with saturated aqueous $\mathrm{NaHCO}_{3}$ and brine, dried over anhydrous sodium sulfate, and concentrated under reduced pressure. Purification through a neutral alumina plug (elution with $1 \% \mathrm{Et}_{3} \mathrm{~N}$ in hexanes) then heating to $50{ }^{\circ} \mathrm{C}$ under vacuum (ca. 0.1 torr) to remove TIPSPOH afforded $0.94 \mathrm{~g}$ (87\% yield, 2:1 mixture of $E$ and $Z$ isomers, 9:1 trisubstituted to monosubstituted siloxyalkene) of silyl enol ether $\mathbf{5 0}$ as a colorless oil.

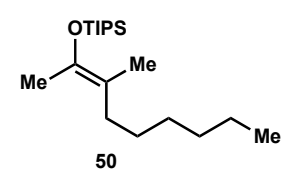

Silyl enol ether $\mathbf{5 0}$

${ }^{1} \mathrm{H}$ NMR $\left(500 \mathrm{MHz}, \mathrm{C}_{6} \mathrm{D}_{6}\right)$ :

$\delta$ 2.32-2.28 $(\mathrm{m}, 1 \mathrm{H})$

$1.45-1.38(\mathrm{~m}, 3 \mathrm{H})$

2.00-1.97 (m, 2H)

$1.38-1.24(\mathrm{~m}, 7.5 \mathrm{H})$

$1.84(\mathrm{~s}, 3 \mathrm{H})$

$1.21-1.08(\mathrm{~m}, 31.5 \mathrm{H})$

$1.82(\mathrm{~s}, 3 \mathrm{H})$

$0.94-0.88(\mathrm{~m}, 4.5 \mathrm{H})$

$1.80(\mathrm{~m}, 1.5 \mathrm{H})$

$1.61(\mathrm{~m}, 1.5 \mathrm{H})$

$1.55-1.48(\mathrm{~m}, 1.5 \mathrm{H})$

${ }^{13} \mathrm{C}$ NMR $\left(125 \mathrm{MHz}, \mathrm{C}_{6} \mathrm{D}_{6}\right)$ :

$\delta 141.5$

32.3

23.18

17.0

140.8

31.9

23.17

16.0

115.8

30.1

18.8

14.4

112.3

29.7

18.6

13.8

33.7

28.9

18.44

13.7

32.5

28.4

18.40

13.2

HRMS (Cl) calculated for $\mathrm{C}_{19} \mathrm{H}_{40} \mathrm{OSi}[\mathrm{M}]^{+}: 312.2849$, found: 312.2844 .

TLC: $\mathrm{Rf}=0.9$ (hexanes) 


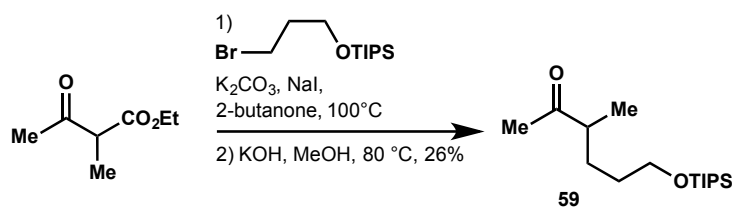

Ketone 59. Ethyl 2-methyl acetoacetate $(3.9 \mathrm{~mL}, 27.3 \mathrm{mmol})$, (3-bromopropoxy)triisopropylsilane ${ }^{5}$ (2.7 g, $9.1 \mathrm{mmol}), \mathrm{K}_{2} \mathrm{CO}_{3}(7.6 \mathrm{~g}, 54.6 \mathrm{mmol})$, sodium iodide $(2.7 \mathrm{~g}, 18.2 \mathrm{mmol})$, and 2-butanone $(27 \mathrm{~mL})$ were combined in a round bottom flask and the slurry was refluxed for $24 \mathrm{~h}$. The reaction was cooled to room temperature, filtered through Celite, and concentrated to yield an orange oil. The crude material was dissolved in $\mathrm{MeOH}(27 \mathrm{~mL})$ and potassium hydroxide $(3.1 \mathrm{~g}, 54.6 \mathrm{mmol})$ was added. The reaction was refluxed for $2 \mathrm{~h}$, cooled to room temperature, concentrated, dissolved in water, and acidified with $2 \mathrm{~N} \mathrm{HCl}$. This mixture was extracted with diethyl ether and the combined organic layers were washed with saturated aqueous $\mathrm{NaHCO}_{3}$ and brine, dried over anhydrous sodium sulfate, and concentrated under reduced pressure. Purification by flash chromatography (gradient elution 1-5\% $\mathrm{Et}_{2} \mathrm{O}$ in hexanes) afforded $0.71 \mathrm{~g}(26 \%$ yield $)$ of ketone 59 as a clear oil.

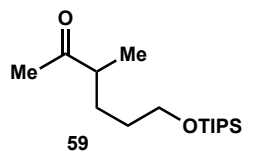

Ketone 59

${ }^{1} \mathrm{H}$ NMR $\left(500 \mathrm{MHz}, \mathrm{CDCl}_{3}\right)$ :

$\delta 3.67(\mathrm{t}, \mathrm{J}=6.2 \mathrm{~Hz}, 2 \mathrm{H})$

2.57-2.50 (m, 1H)

$2.13(\mathrm{~s}, 3 \mathrm{H})$

$1.76-1.70(\mathrm{~m}, 1 \mathrm{H})$

$1.55-1.40(\mathrm{~m}, 3 \mathrm{H})$

$1.09(\mathrm{~d}, \mathrm{~J}=7.0 \mathrm{~Hz}, 3 \mathrm{H})$

$1.08-1.03(\mathrm{~m}, 21 \mathrm{H})$

${ }^{13} \mathrm{C}$ NMR $\left(125 \mathrm{MHz}, \mathrm{CDCl}_{3}\right)$ :

$\delta 213.0$

29.3

HRMS (ESI) calculated for $\mathrm{C}_{16} \mathrm{H}_{34} \mathrm{O}_{2} \mathrm{SiNa}[\mathrm{M}+\mathrm{Na}]^{+}: 309.2226$, found: 309.2216.

TLC: $\mathrm{Rf}=0.3(5 \%$ EtOAc in hexanes) 

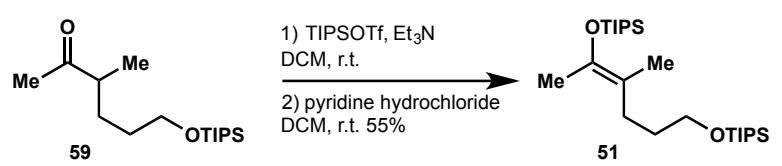

Silyl enol ether 51. TIPSOTf $(0.71 \mathrm{~mL}, 2.6 \mathrm{mmol})$ was added to a solution of ketone $59(0.71 \mathrm{~g}, 2.4$ $\mathrm{mmol})$ in DCM $(7 \mathrm{~mL})$. Triethylamine $(0.6 \mathrm{~mL}, 4.3 \mathrm{mmol})$ was added over 2 minutes. The reaction was stirred at room temperature for $3 \mathrm{~h}$, then diluted in hexanes, washed with saturated aqueous $\mathrm{NaHCO}_{3}$ and brine, dried over anhydrous sodium sulfate, and concentrated under reduced pressure to yield exclusively the monosubstituted silyl enol ether. The crude material was dissolved in DCM $(2.5 \mathrm{~mL})$ and added to a Schlenk flask charged with pyridine hydrochloride $(0.028 \mathrm{~g}, 0.24 \mathrm{mmol})$ and stirred at room temperature for $16 \mathrm{~h}$. The reaction was quenched with $1 \mathrm{~mL} \mathrm{Et}{ }_{3} \mathrm{~N}$, diluted with hexanes, washed with saturated aqueous $\mathrm{NaHCO}_{3}$ and brine, dried over anhydrous sodium sulfate, and concentrated under reduced pressure. Purification on $\mathrm{Et}_{3} \mathrm{~N}$-treated silica (elution with $1 \% \mathrm{Et}_{3} \mathrm{~N}$ in hexanes) afforded $1.17 \mathrm{~g}(55 \%$ yield, 1:2 mixture of $E$ and $Z$ isomers, 8:1 trisubstituted to disubstituted siloxyalkene) of silyl enol ether $\mathbf{5 1}$ as a colorless oil.

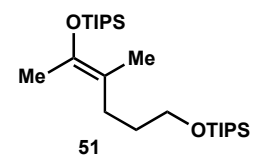

Silyl enol ether $\mathbf{5 1}$

${ }^{1} \mathrm{H}$ NMR $\left(500 \mathrm{MHz}, \mathrm{C}_{6} \mathrm{D}_{6}\right)$ :

$\delta 3.80(\mathrm{t}, \mathrm{J}=6.86 \mathrm{~Hz}, 1 \mathrm{H})$

$1.77(\mathrm{~s}, 1.5 \mathrm{H})$

$3.64(\mathrm{t}, \mathrm{J}=6.18 \mathrm{~Hz}, 2 \mathrm{H})$

$1.71-1.63(\mathrm{~m}, 2 \mathrm{H})$

2.37-2.34 (m, 1H)

$1.61(\mathrm{~s}, 1.5 \mathrm{H})$

2.16-2.13 (m, 2H)

1.20-1.07 (m, 63H)

$1.90(\mathrm{~s}, 3 \mathrm{H})$

1.87-1.83 $(\mathrm{m}, 1 \mathrm{H})$

$1.82(\mathrm{~s}, 3 \mathrm{H})$

${ }^{13} \mathrm{C}$ NMR (125 MHz, $\left.\mathrm{C}_{6} \mathrm{D}_{6}\right)$ :

б 141.8

32.3

18.44

13.8

141.0

31.9

18.40

13.7

112.2

30.0

18.38

12.5

111.8

28.3

18.35

12.4

64.4

18.8

17.0

63.3

18.6

16.0

HRMS (Cl) calculated for $\mathrm{C}_{25} \mathrm{H}_{55} \mathrm{O}_{2} \mathrm{Si}_{2}[\mathrm{M}+\mathrm{H}]^{+}: 443.3741$, found: 443.3749 .

TLC: $R f=0.55$ (hexanes) 


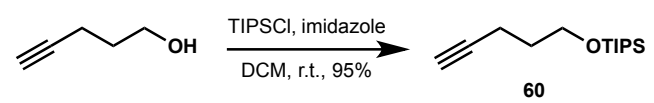

Alkyne 60. TIPSCI (4.5 mL, $15 \mathrm{mmol})$, 4-pentyn-1-ol $(1.4 \mathrm{~mL}, 15 \mathrm{mmol})$, and imidazole $(2.0 \mathrm{~g}, 30 \mathrm{mmol})$ were dissolved in DCM and stirred at room temperature for $2 \mathrm{~h}$. The reaction was diluted in hexanes, washed with saturated aqueous $\mathrm{NaHCO}_{3}$ and brine, dried over anhydrous sodium sulfate, and concentrated under reduced pressure. Purification by flash chromatography (elution with hexanes) afforded $3.4 \mathrm{~g}$ (95\% yield) of alkyne 60 as a colorless oil. ${ }^{1} \mathrm{H}$ and ${ }^{13} \mathrm{C}$ NMR data match that provided in the literature. ${ }^{6}$ 


\section{Comments on selectivity toward fully substituted enoxysilanes and its origins}

The following observation demonstrates that the selectivity toward fully substituted enoxysilanes is not exclusive:

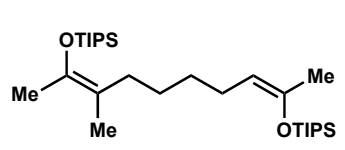

61 (mix. of diast.)

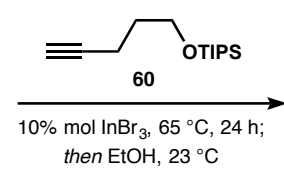

then $\mathrm{EtOH}, 23^{\circ} \mathrm{C}$

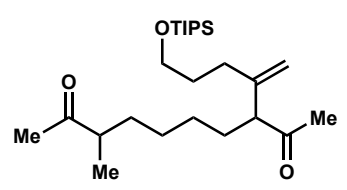

62 (mix. of diast.): ca. $30 \%$ by ${ }^{1} \mathrm{H}$ NMR

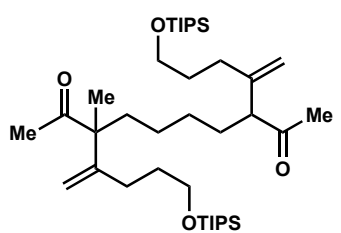

63 (mix. of diast.): ca. $15 \%$ by ${ }^{1} \mathrm{H}$ NMR

In this case, alkenylation of bis-silyl enol ether $\mathbf{6 1}$ with alkyne 60 afforded a mixture of products 62 and 63, suggesting that both siloxyalkenes of $\mathbf{6 1}$ are reactive towards alkenylation (and the less substituted siloxyalkene is even more reactive than the fully substituted fragment in this case).

This observation supports our proposal that the selectivity of alkenylation results from the difference in the conformational preferences of the siloxy group in different enoxysilanes. Thus, in the case of our typical starting silyl enol ether, the siloxy group preferentially adopts conformation $\mathbf{S} 1$ (inset right; $\mathbf{R}^{1}, \mathbf{R}^{2}, \mathbf{R}^{3}=$ alkyl) and not $\mathbf{S 2}$, where it would experience unfavorable steric interactions with substituent $\mathbf{R}^{3}$. Conformation $\mathbf{S} 1$ should also be

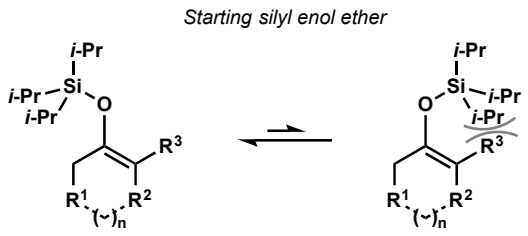

s1

preferred and MORE reactive

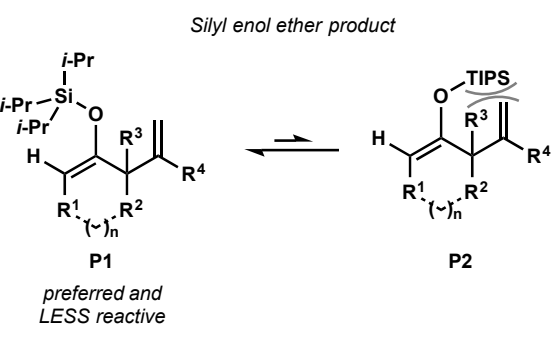
LESS reactive more reactive towards the electrophilic attack by the indium(III)alkyne complex for steric reasons. However, the opposite should be true in the case of the siloxydiene product, where the preferred conformation $\mathbf{P} 1\left(\mathbf{R}^{4}=\right.$ alkyl, alkenyl, aryl) should be less reactive towards the electrophilic attack by the indium(III)alkyne complex, because the siloxy group would sterically interfere with the trajectory of the attack. Similar considerations should be applicable in the case of 61 , where the conformational preferences of the siloxy groups in both enoxysilane fragments should follow the same pattern, and both enoxysilane fragments are predicted to be reactive under our conditions.

These observations may suggest that less substituted silyl enol ethers can be viable substrates for this alkenylation process. We note, however, that our preliminary explorations in this area have so far resulted

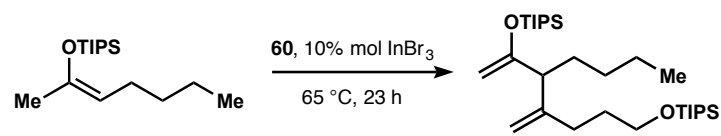

64 (mix. of diast.)
65: $24 \%$ by ${ }^{1} \mathrm{H}$ NMR in mixed outcomes. For example, while attempted alkenylation of 2-heptanone-derived silyl enol ether 64 resulted in some success (inset right), attempted alkenylation of triisopropylsilyl enol ether derived from cyclopentanone failed. 


\section{References}

(1) Kinoshita, H; Ishikawa, T; Miura, K. Org. Lett. 2011, 13, 6192-6195.

(2) Magnus, P.; Lacour, J.; Coldham, I.; Mugrage, B.; Bauta, W. B. Tetrahedron 1995, 51, 11087-11110.

(3) Shih, H. W.; Prescher, J. A. J. Am. Chem. Soc. 2015, 137, 10036-10039.

(4) Mo, F.; Dong, G. Science 2014, 345, 68-72.

(5) Cortez, F. de J.; Sarpong, R. Org. Lett. 2010, 12, 1428-1431.

(6) Ishiyama, H.; Takemura, T.; Tsuda, M.; Kobayashi, J. Tetrahedron 1999, 55, 4583-4594. 


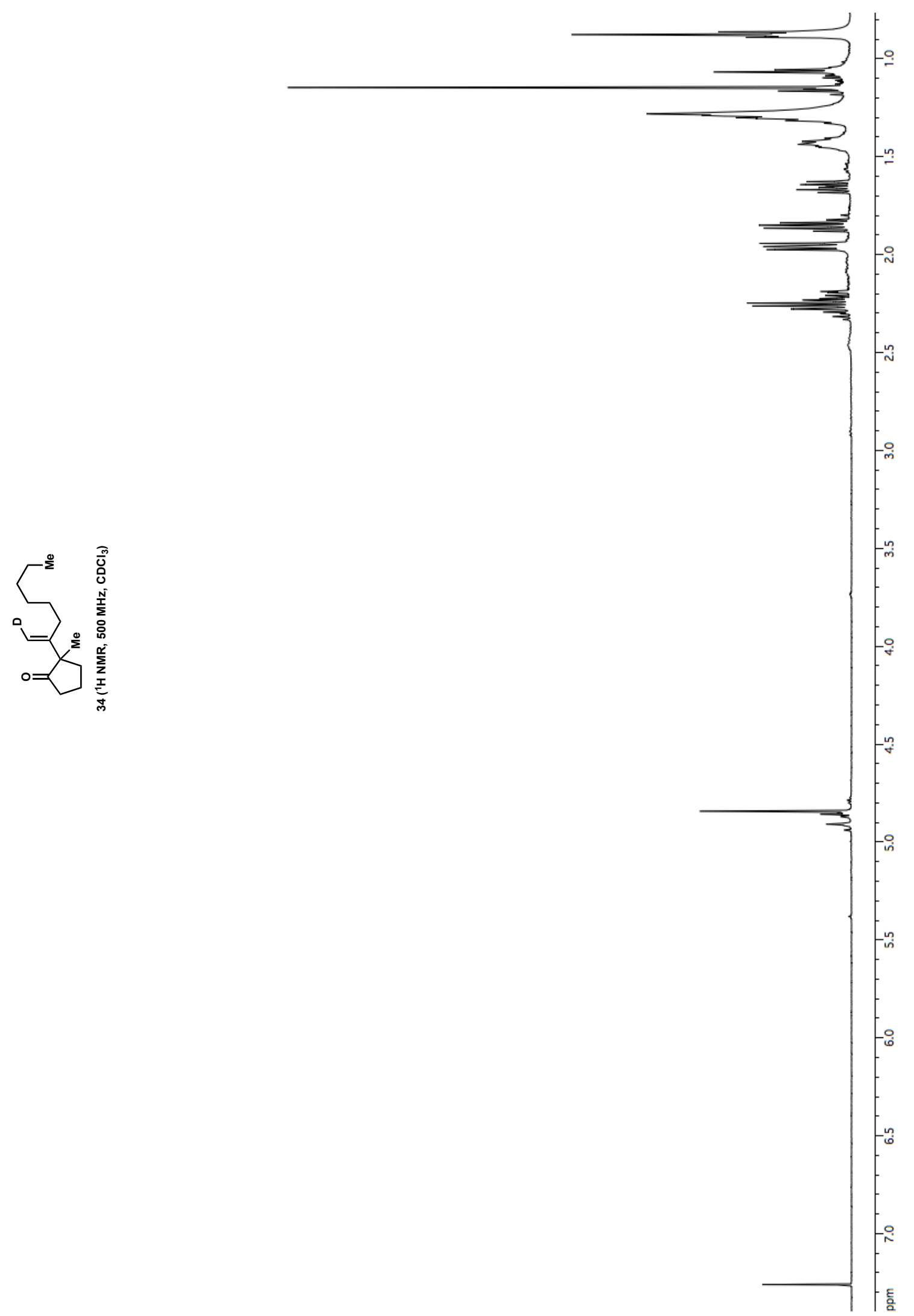



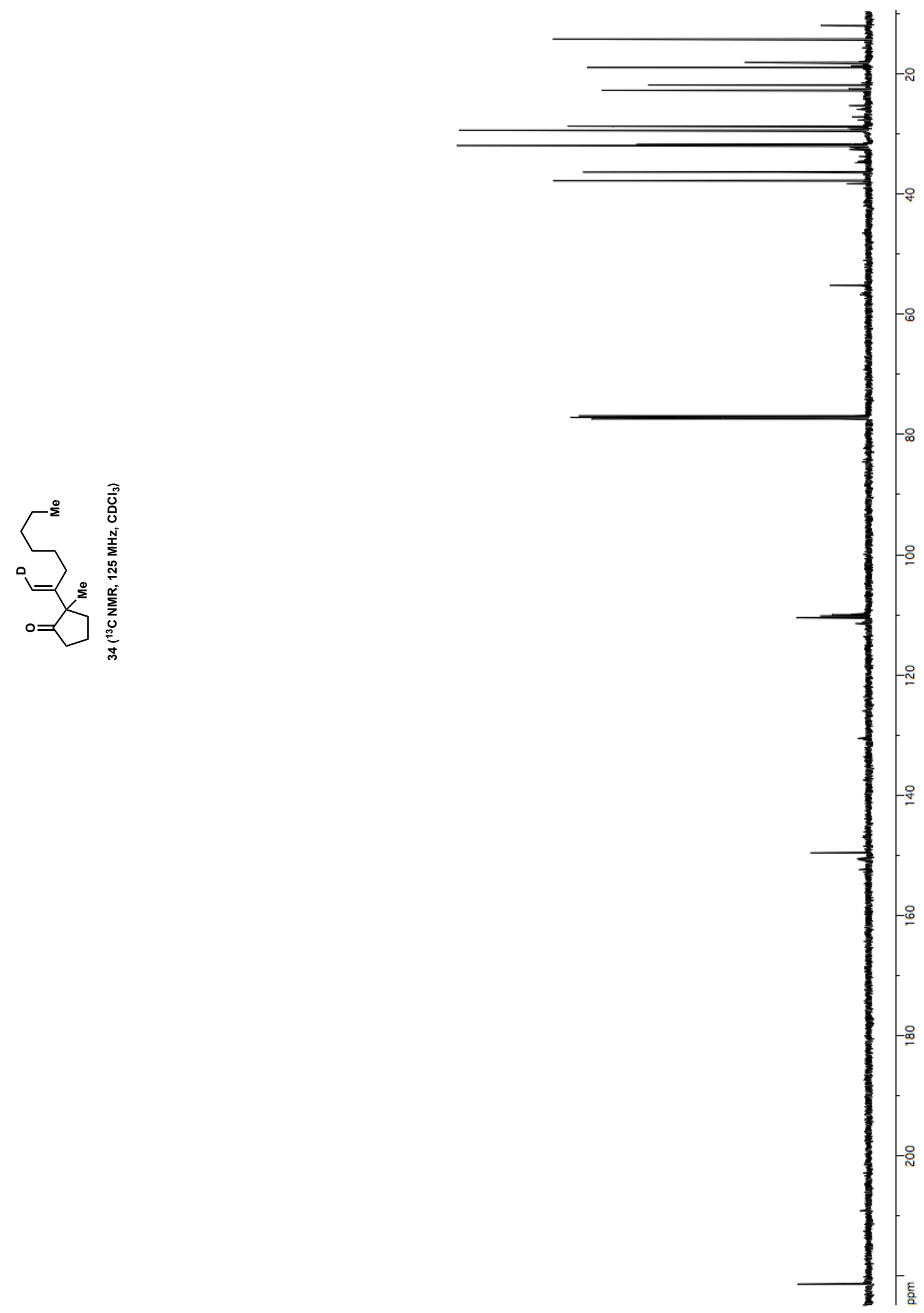

SI 56 


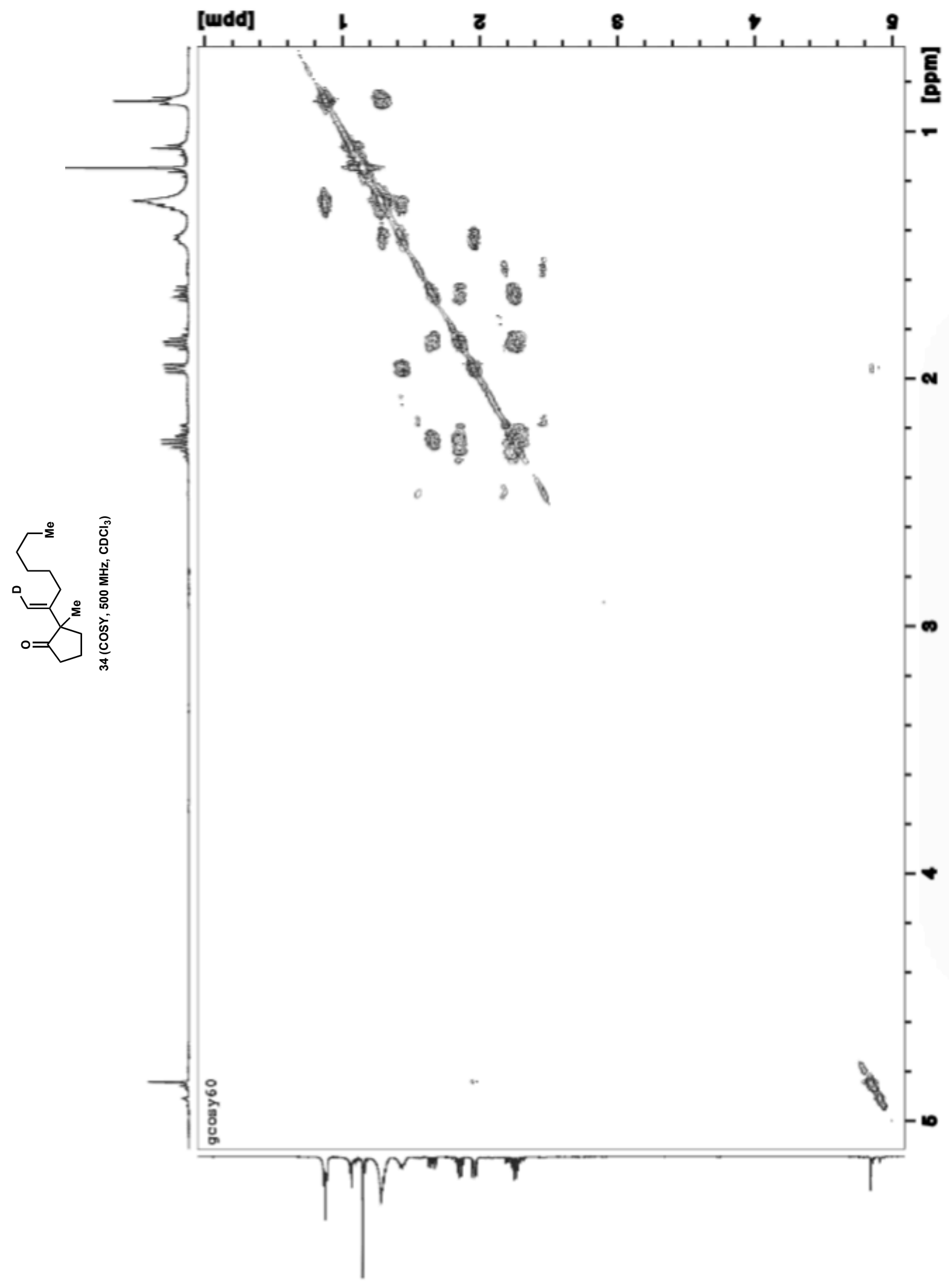




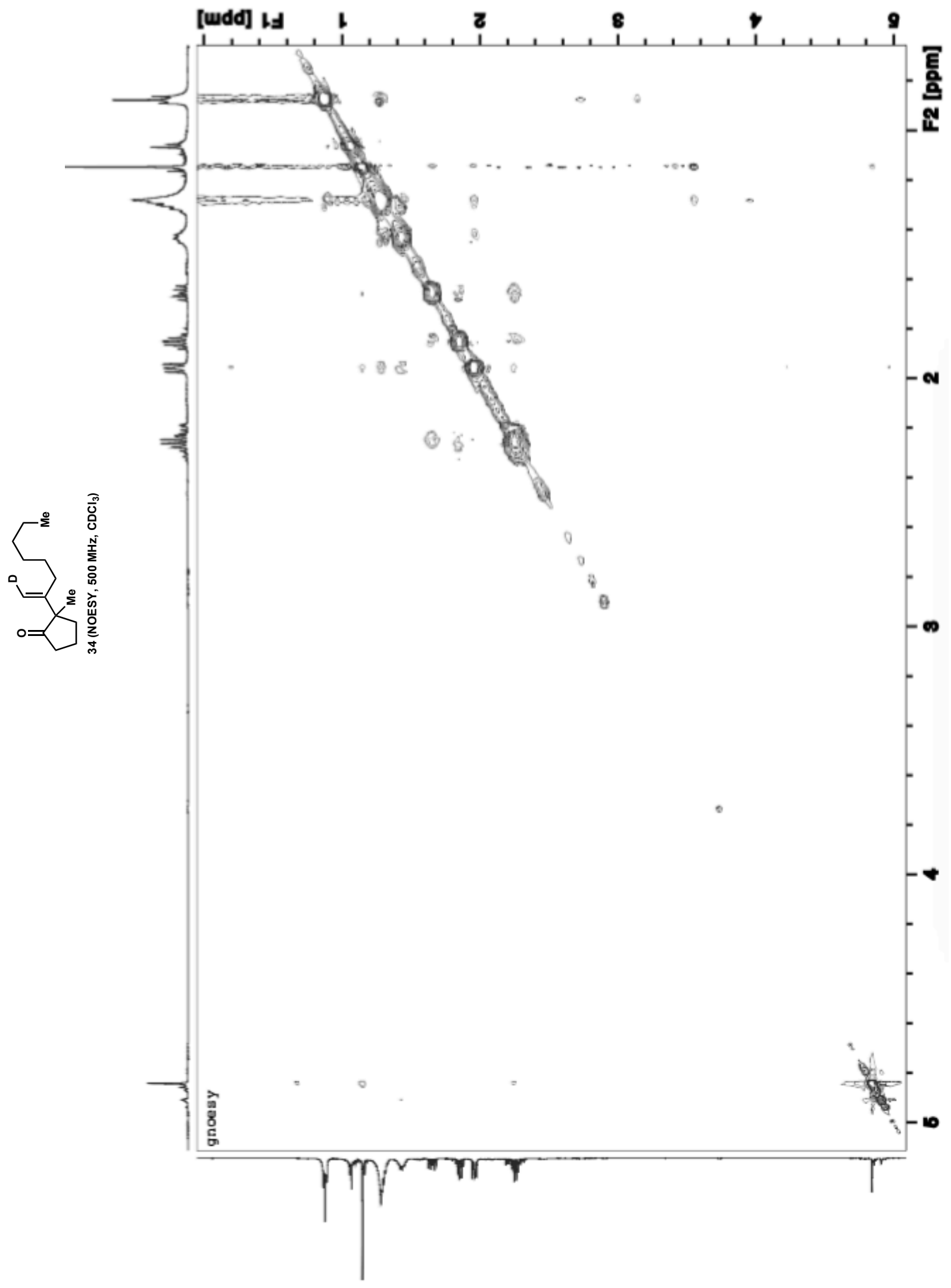

SI 58 


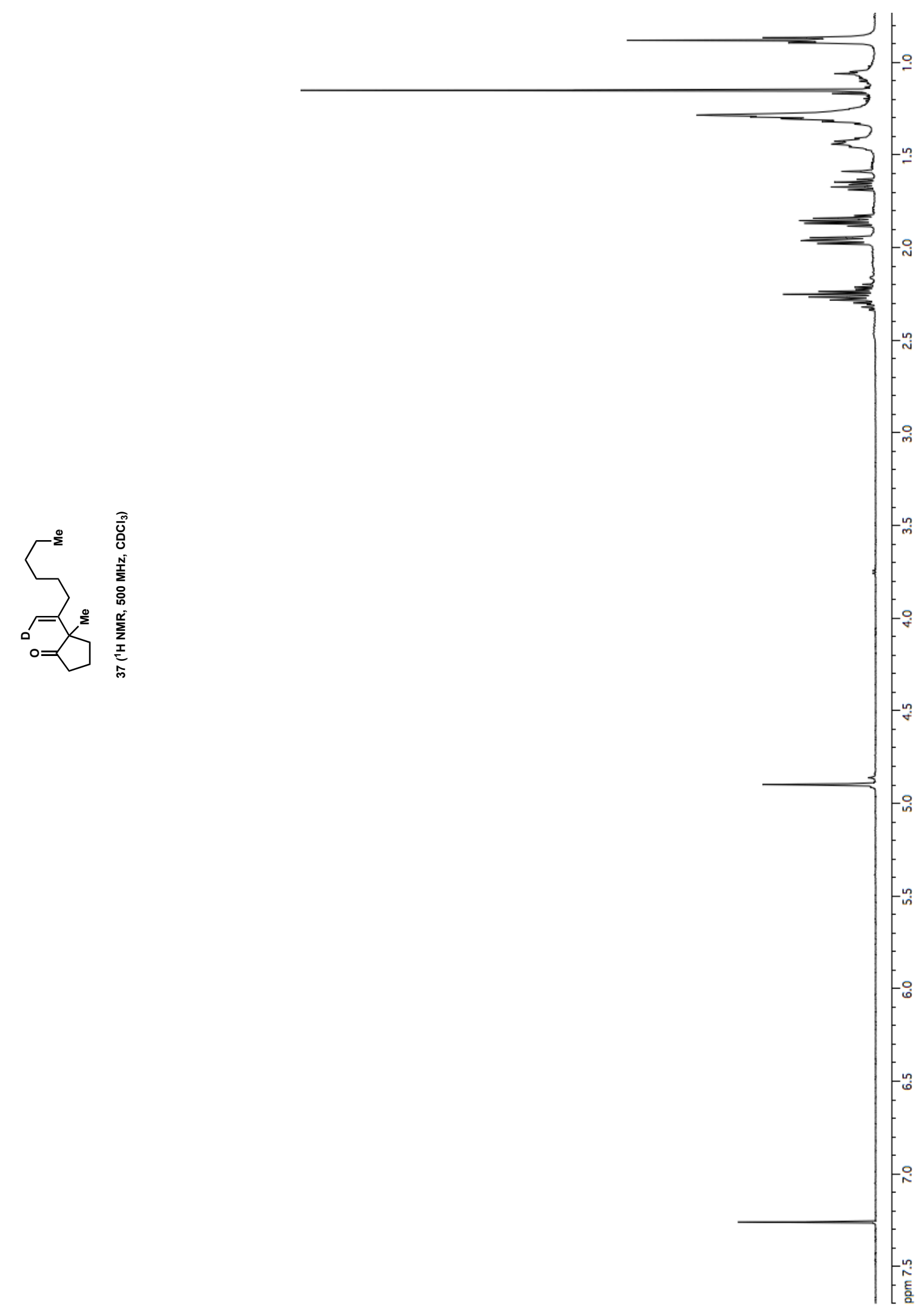




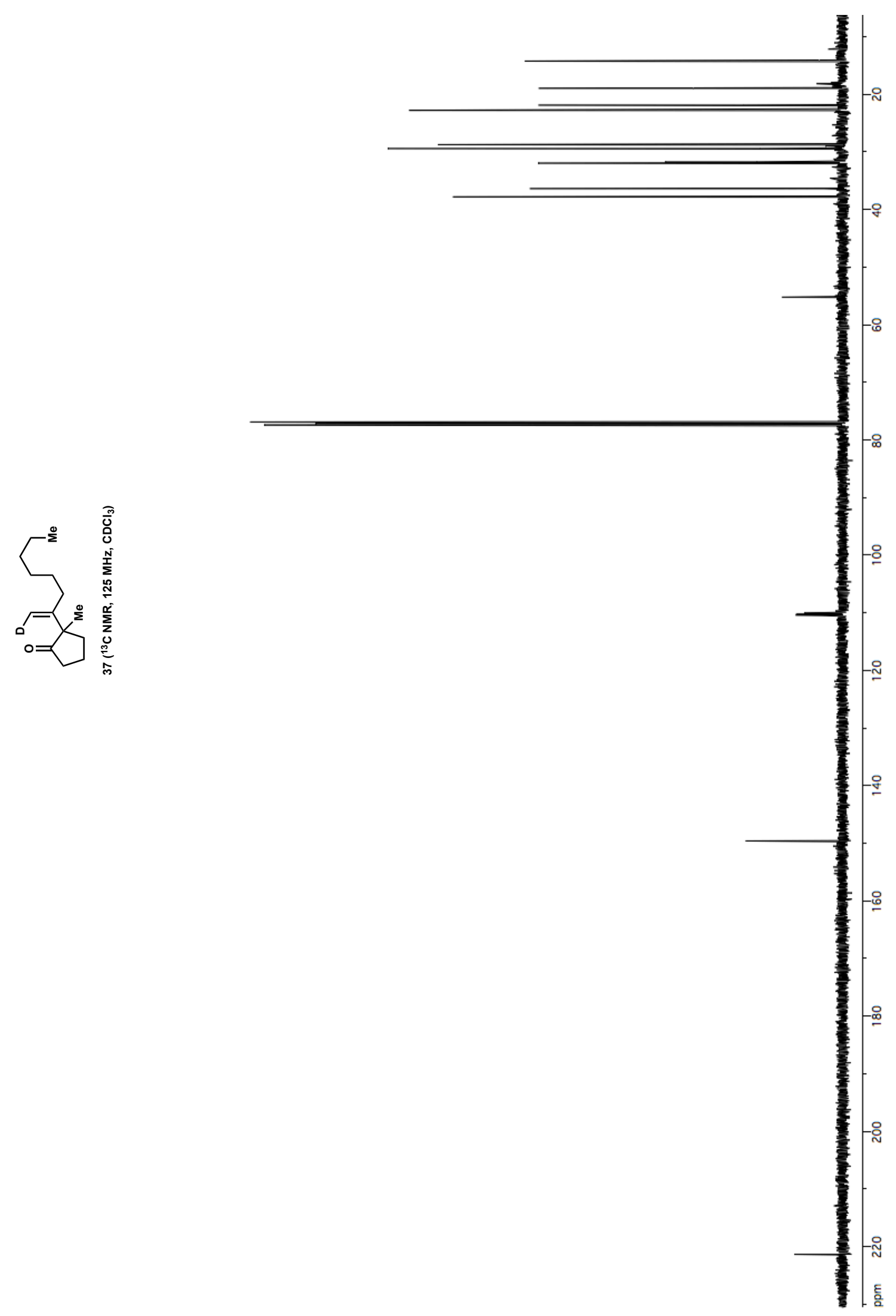

SI 60 


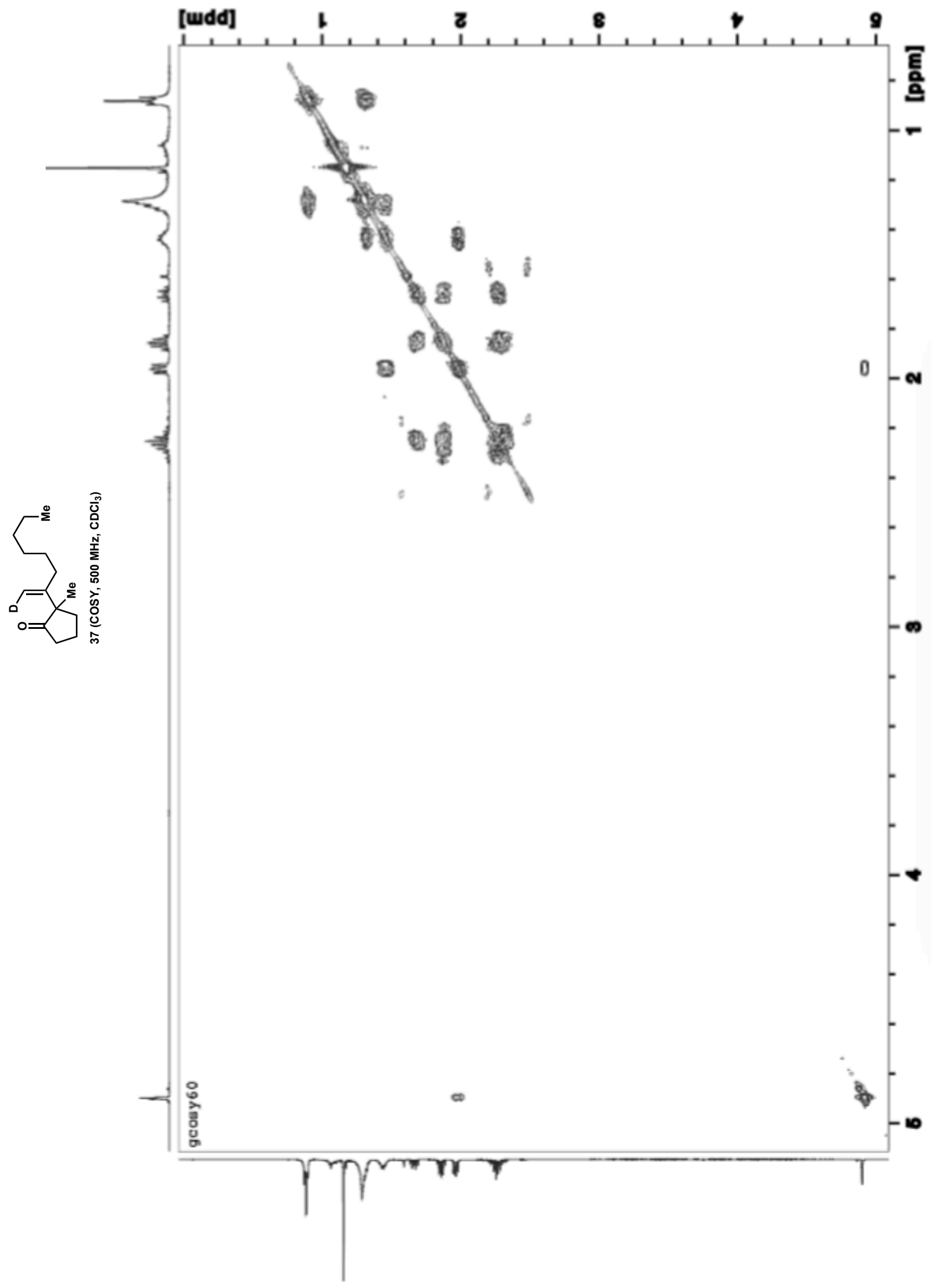

SI 61 


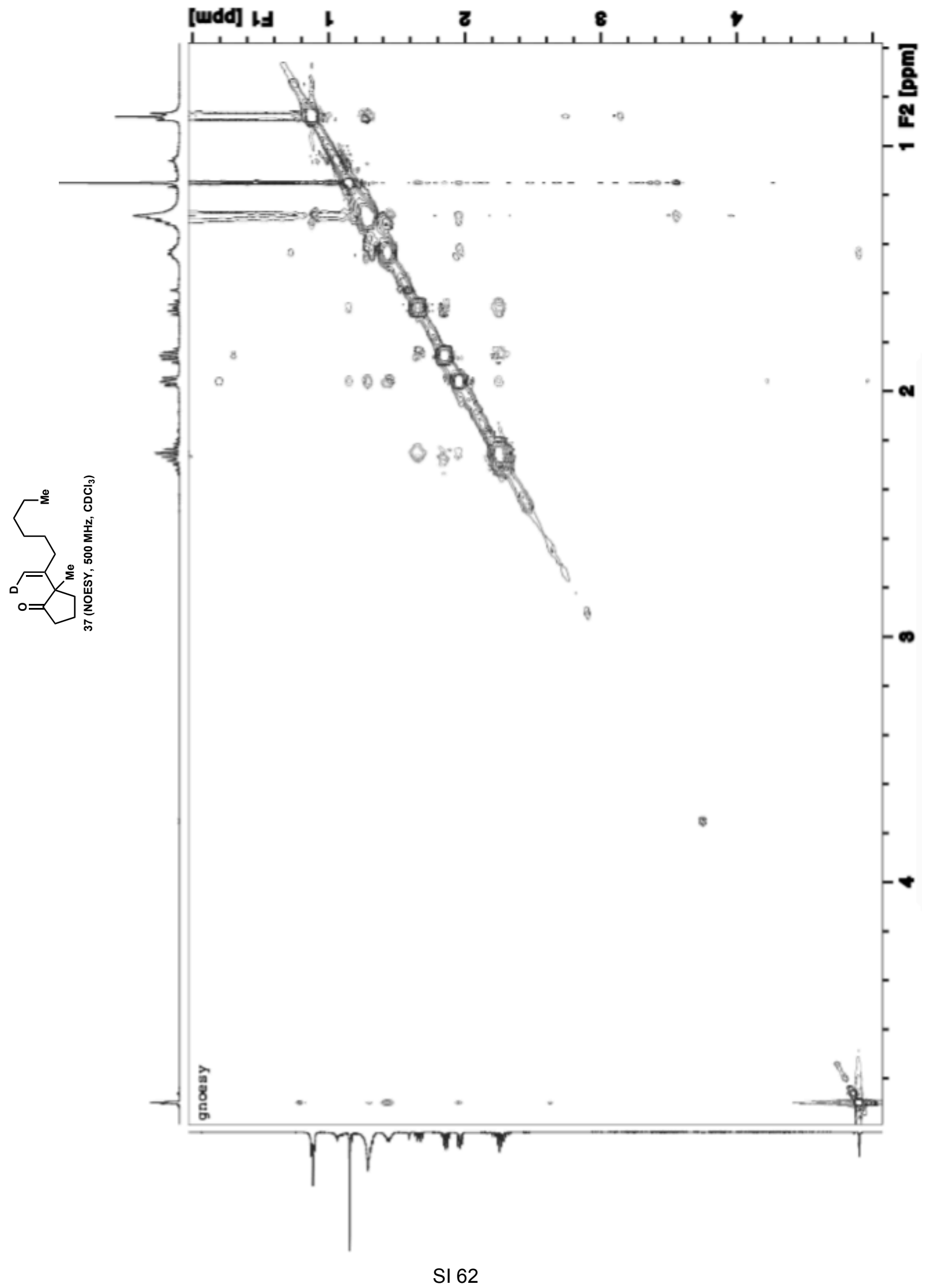




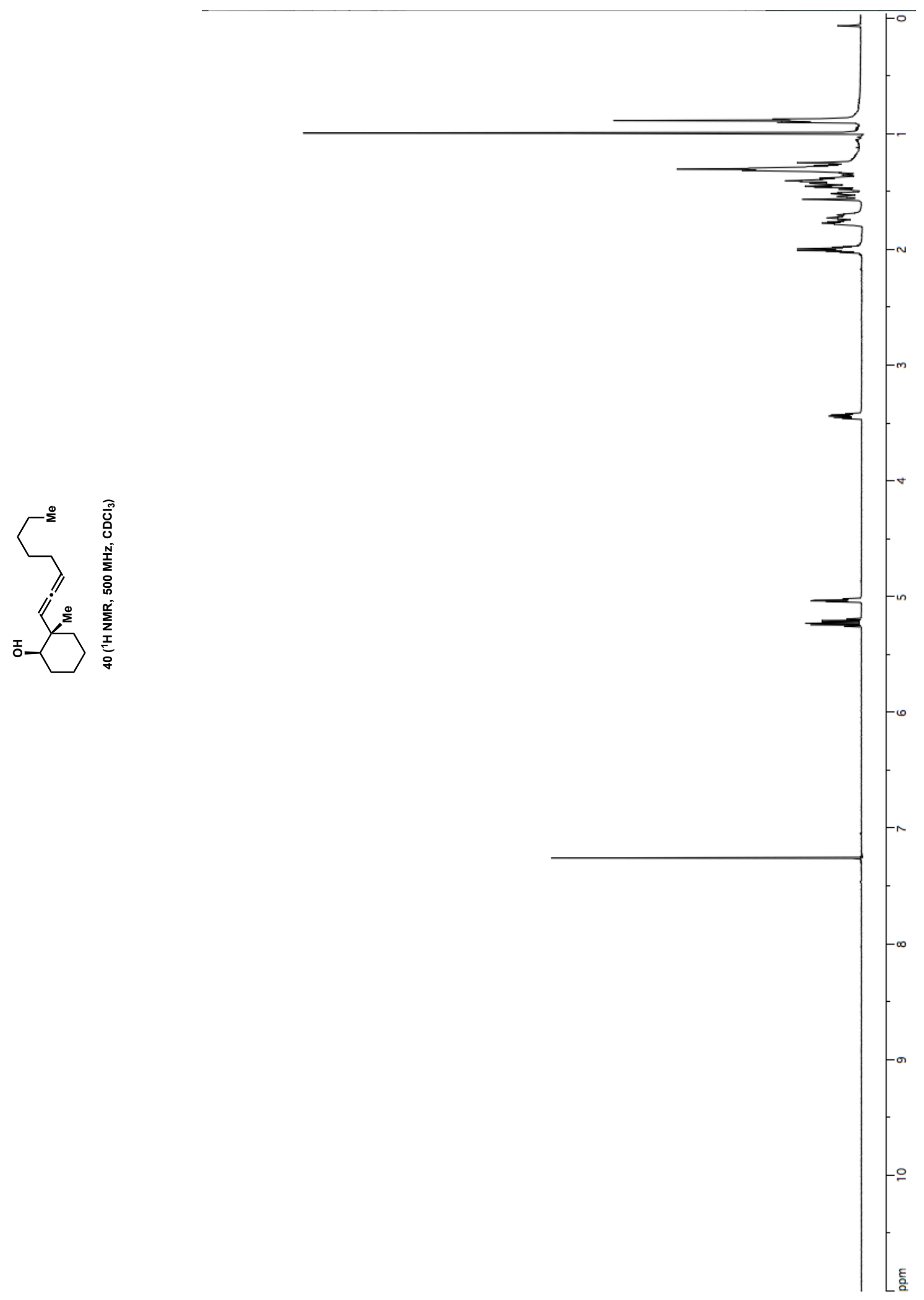




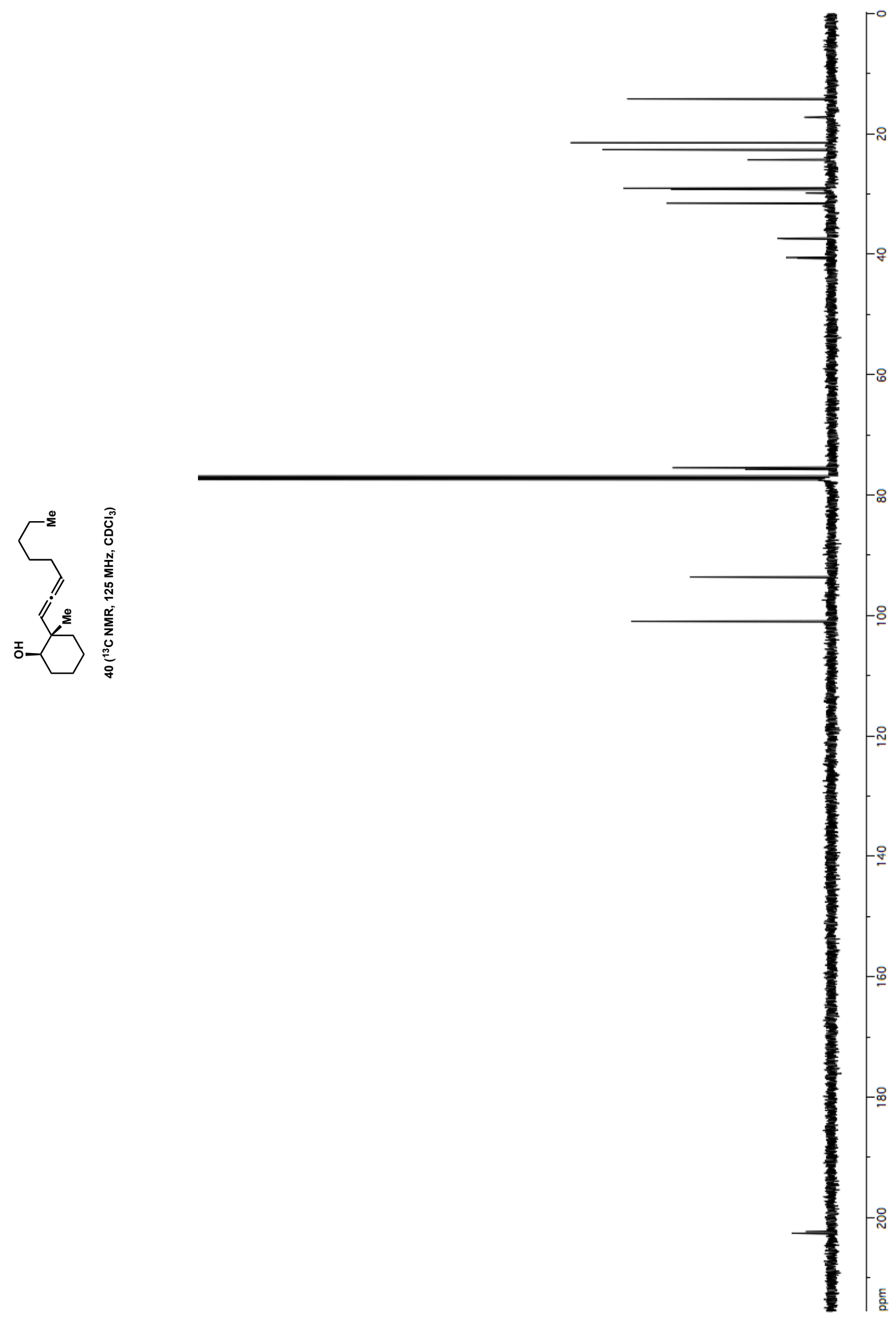

SI 64 


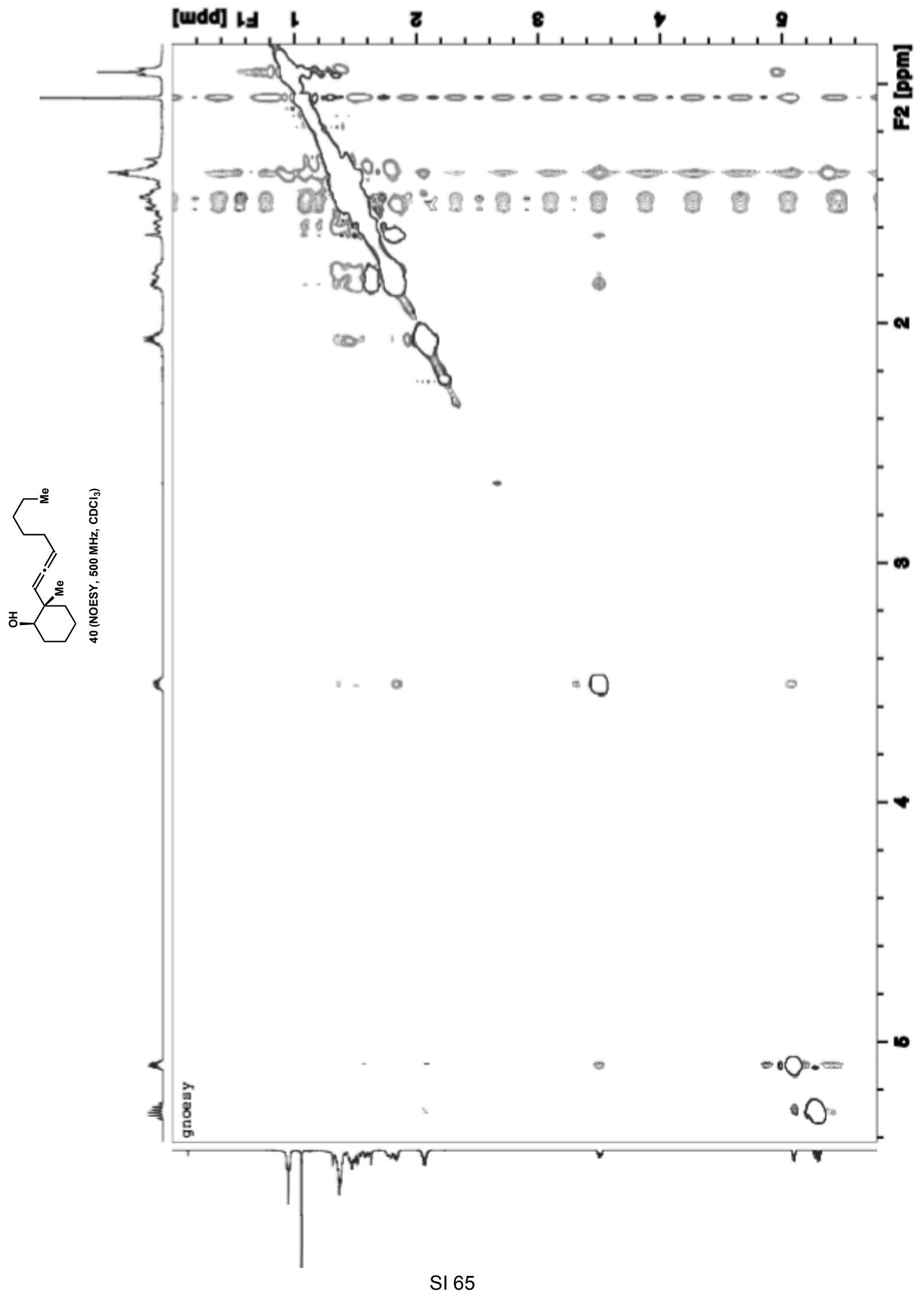




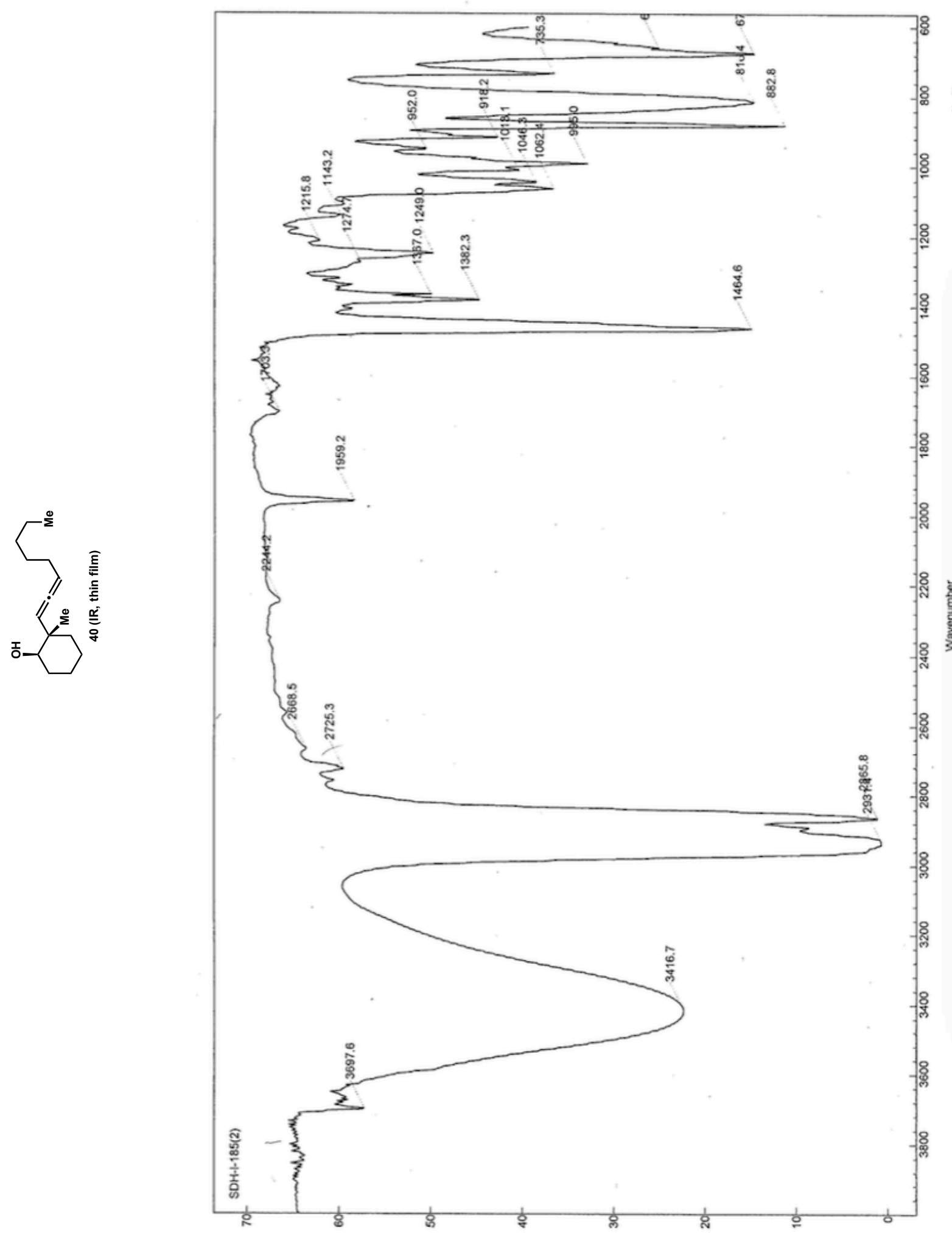

องueprusues $1 \%$ 


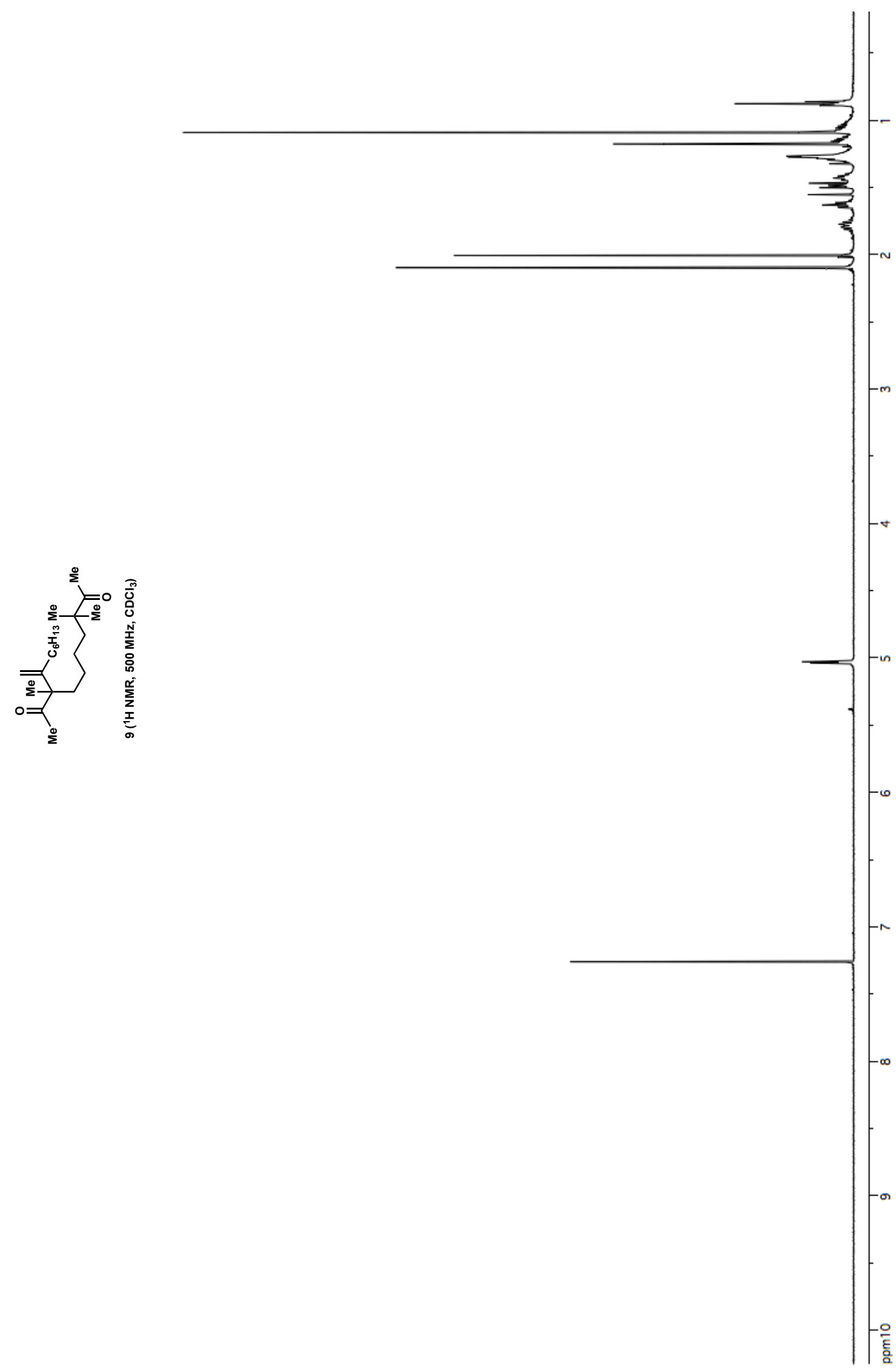




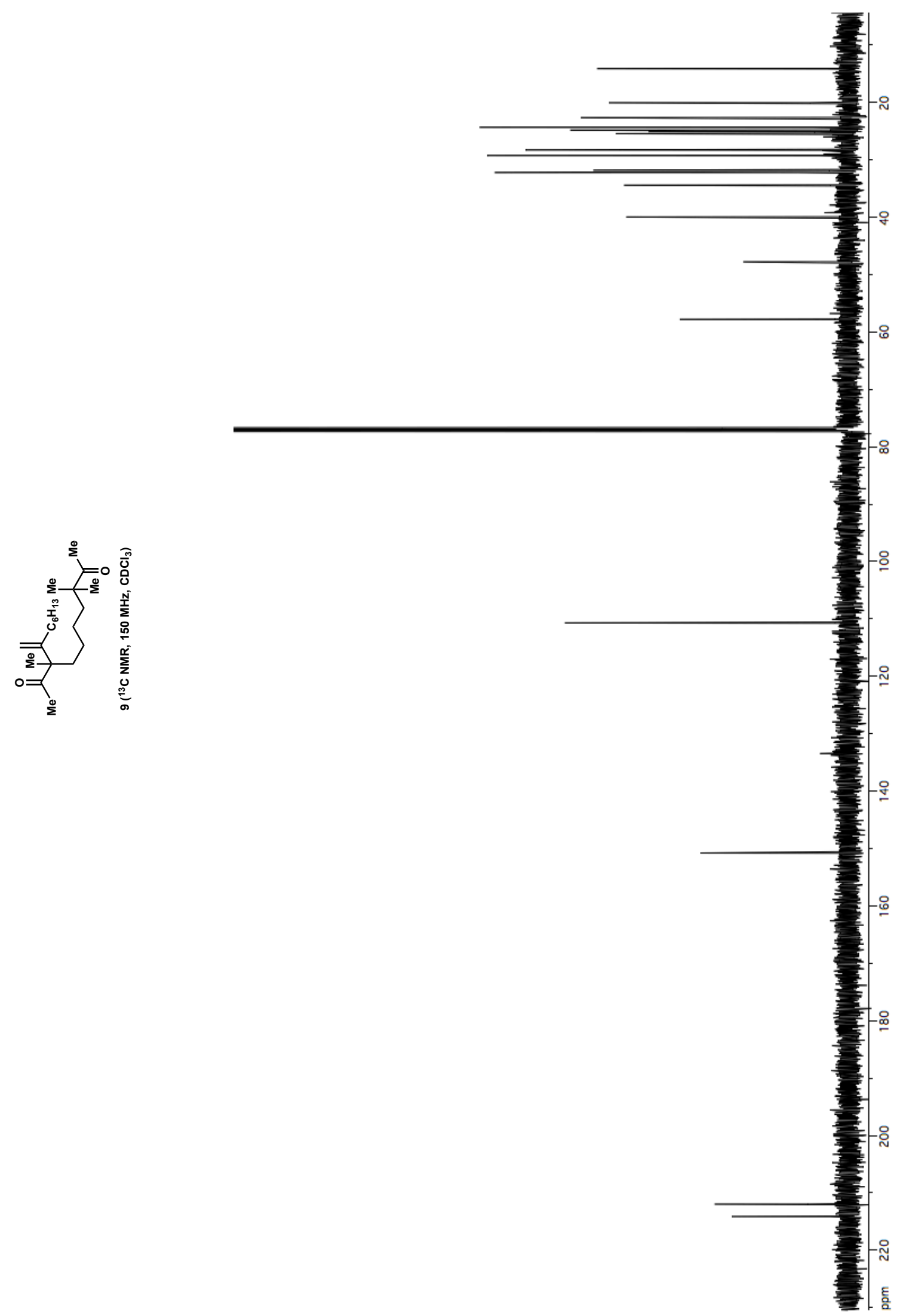

SI 68 


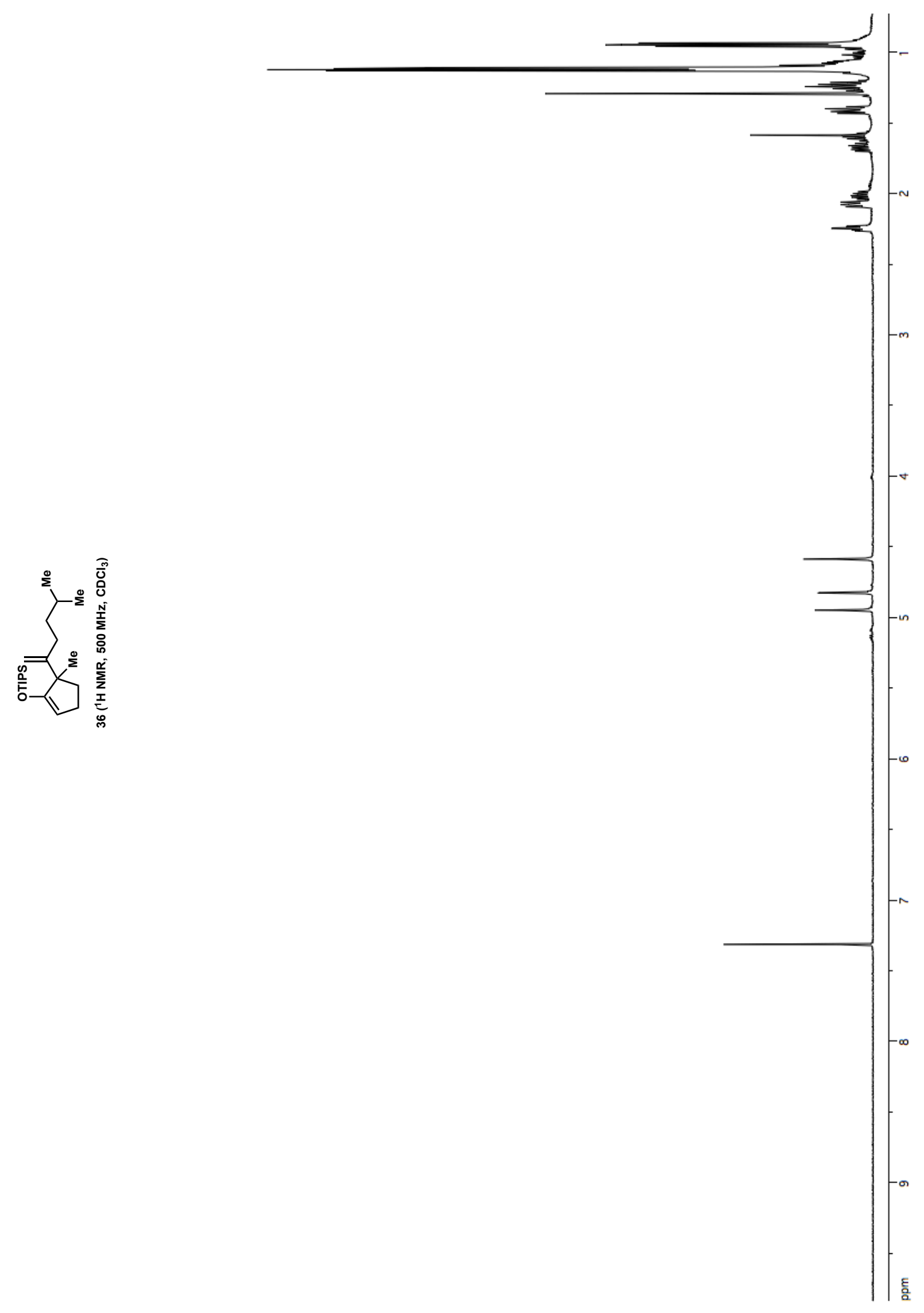




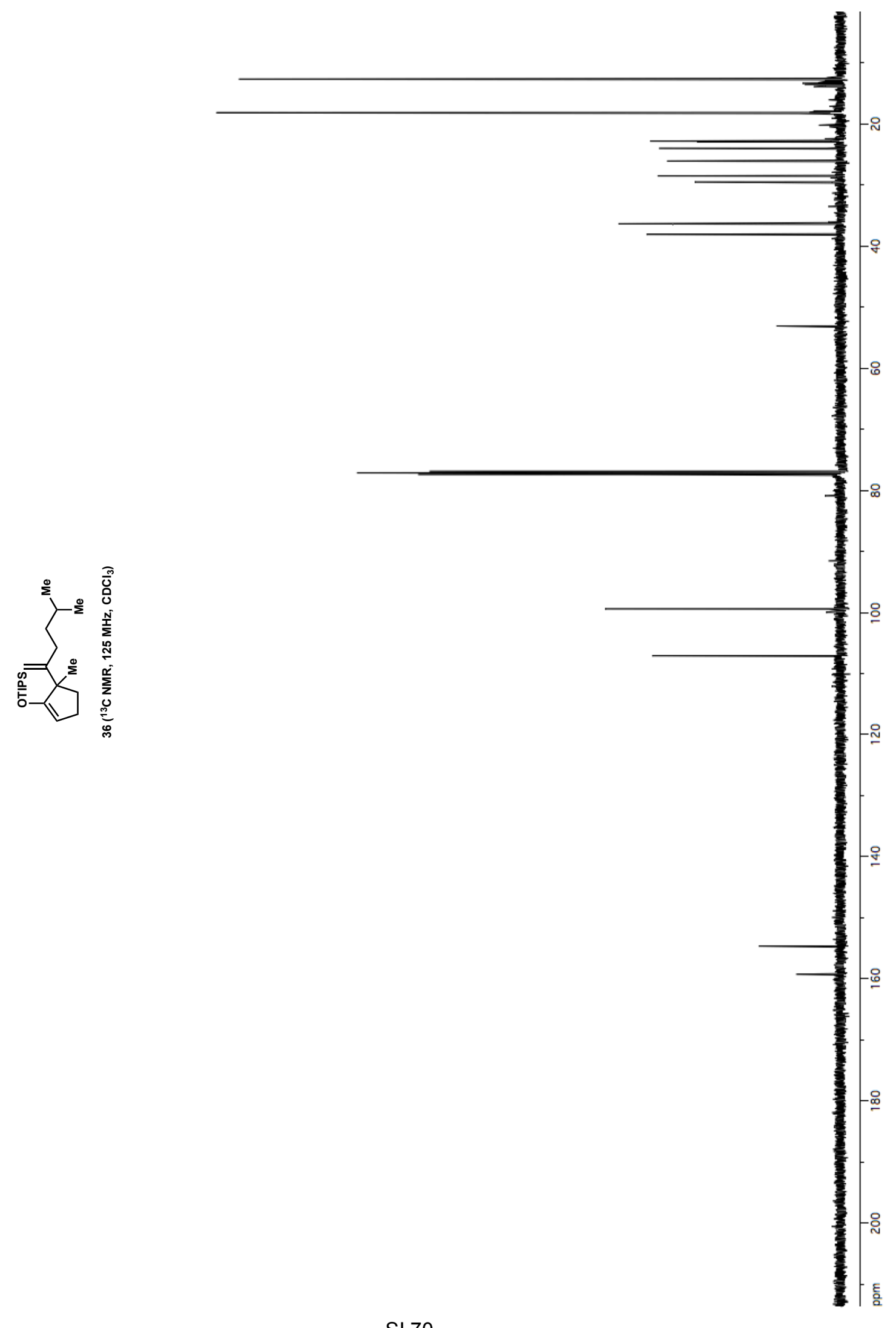




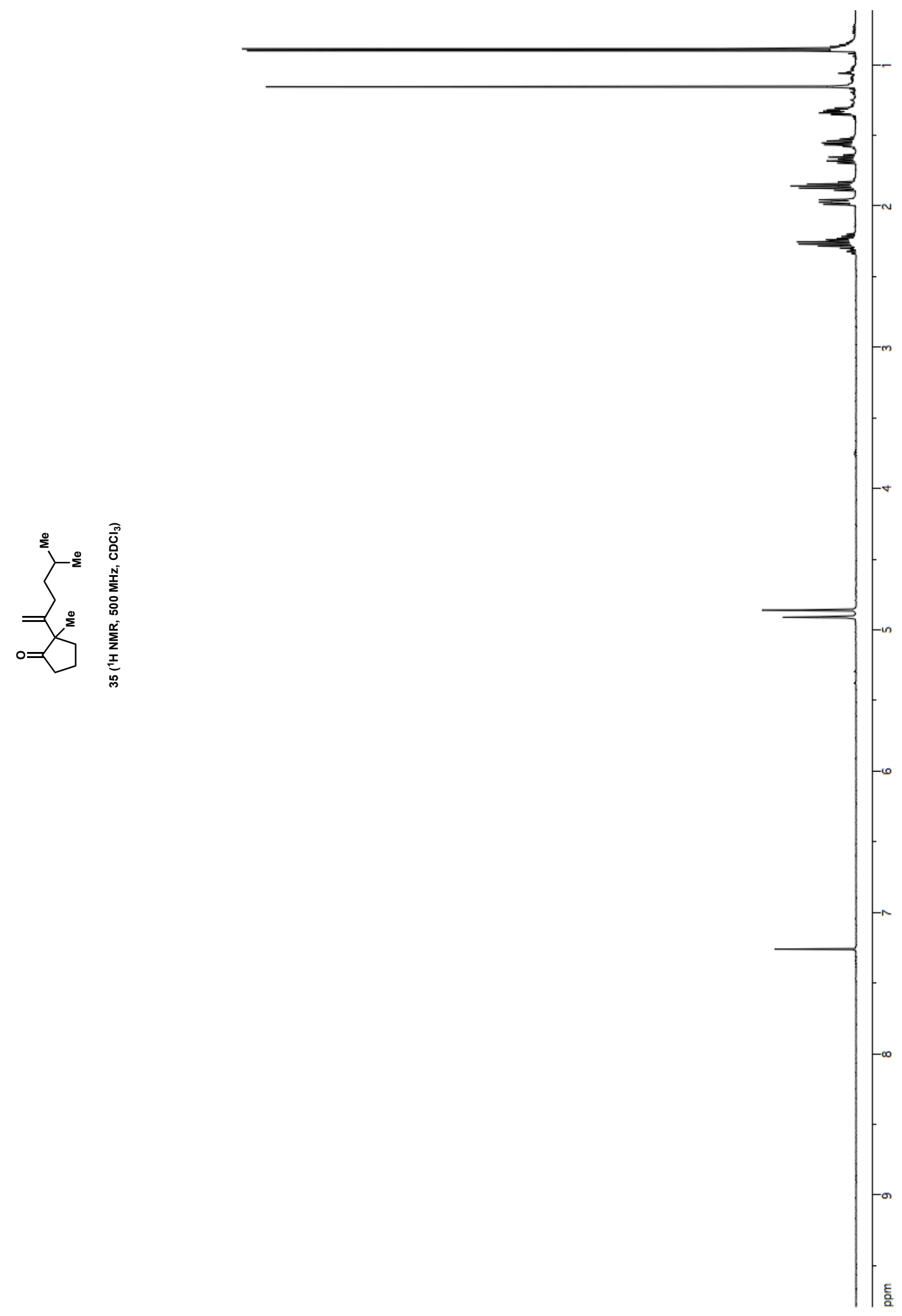




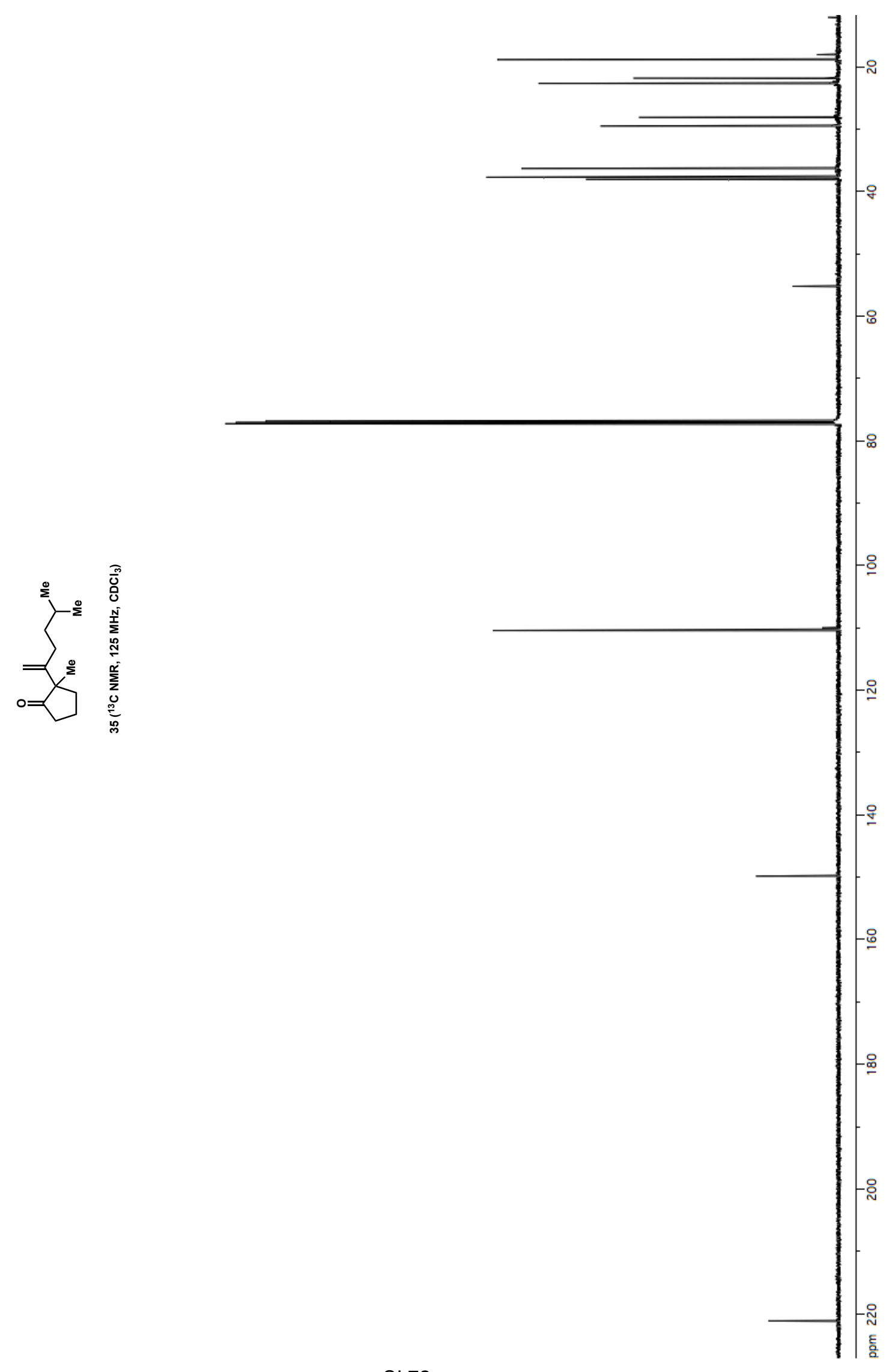




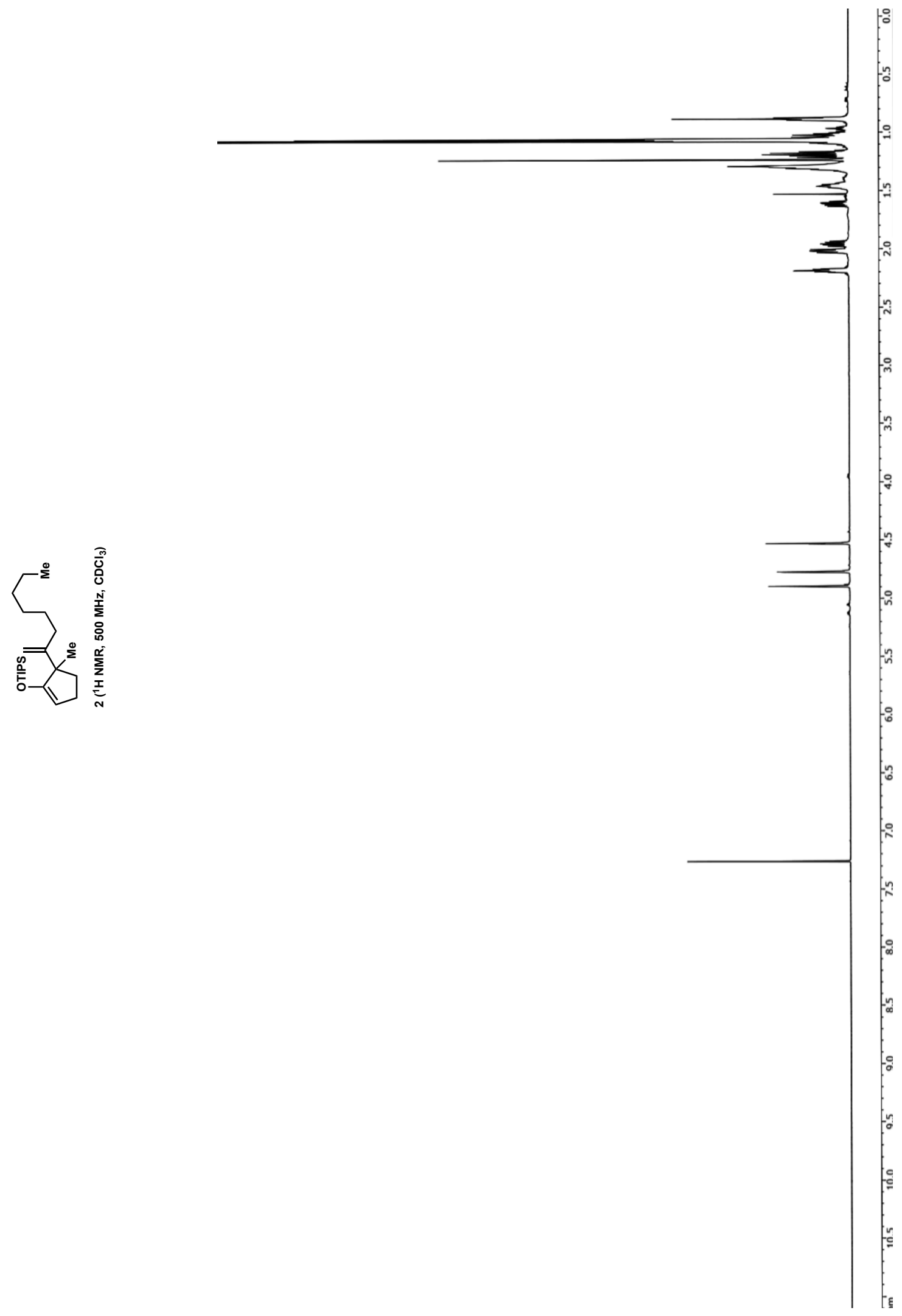



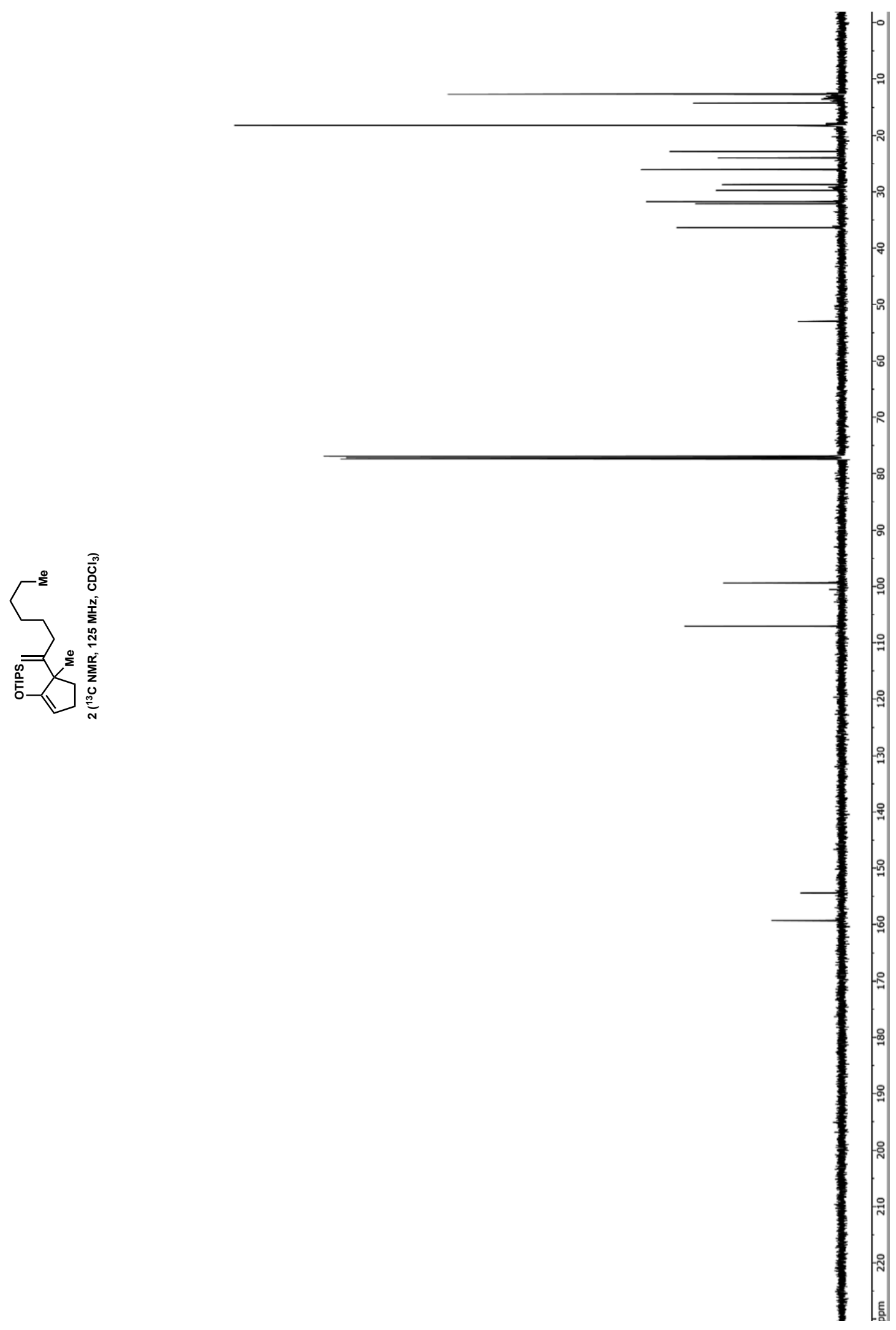


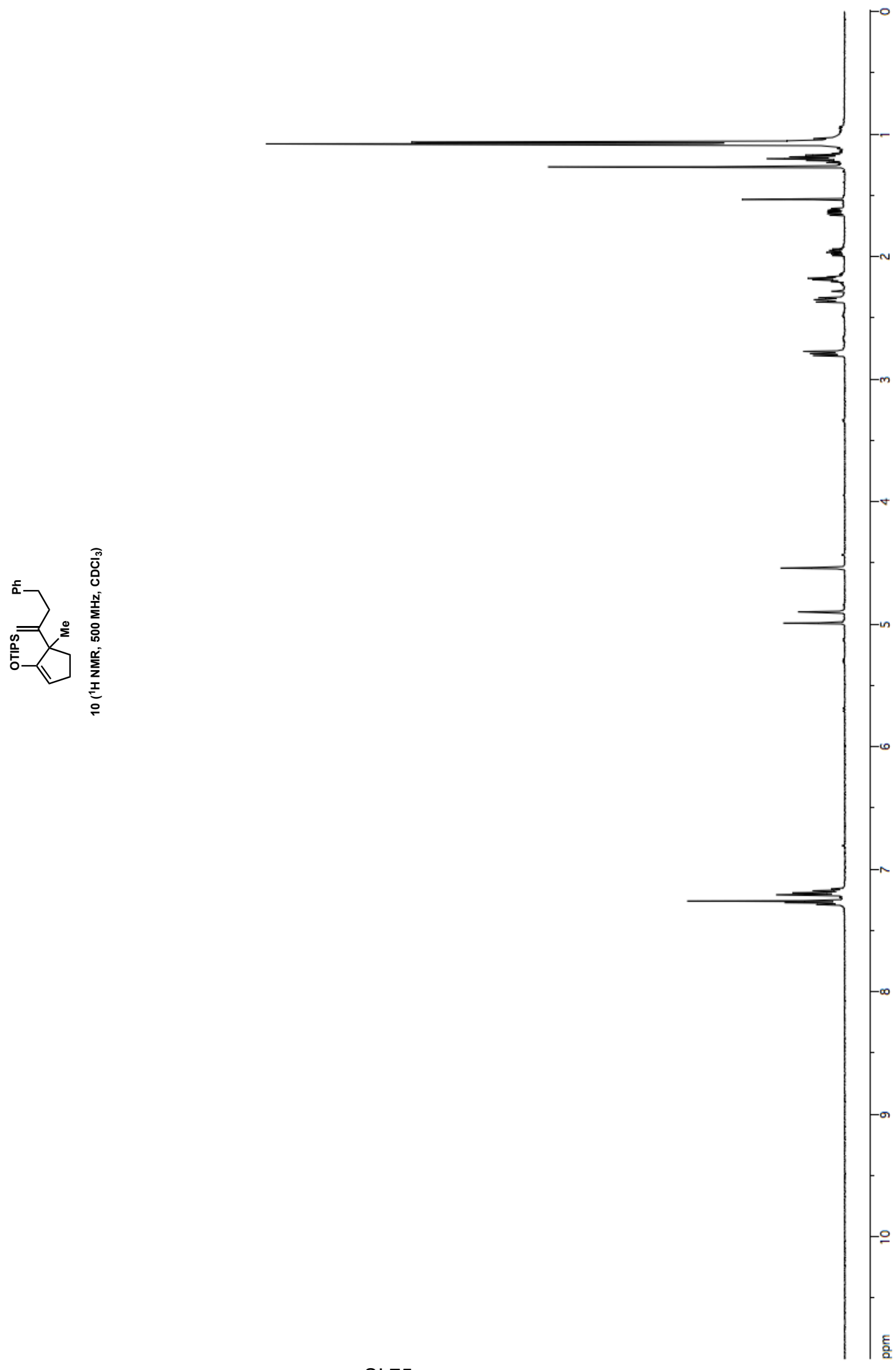



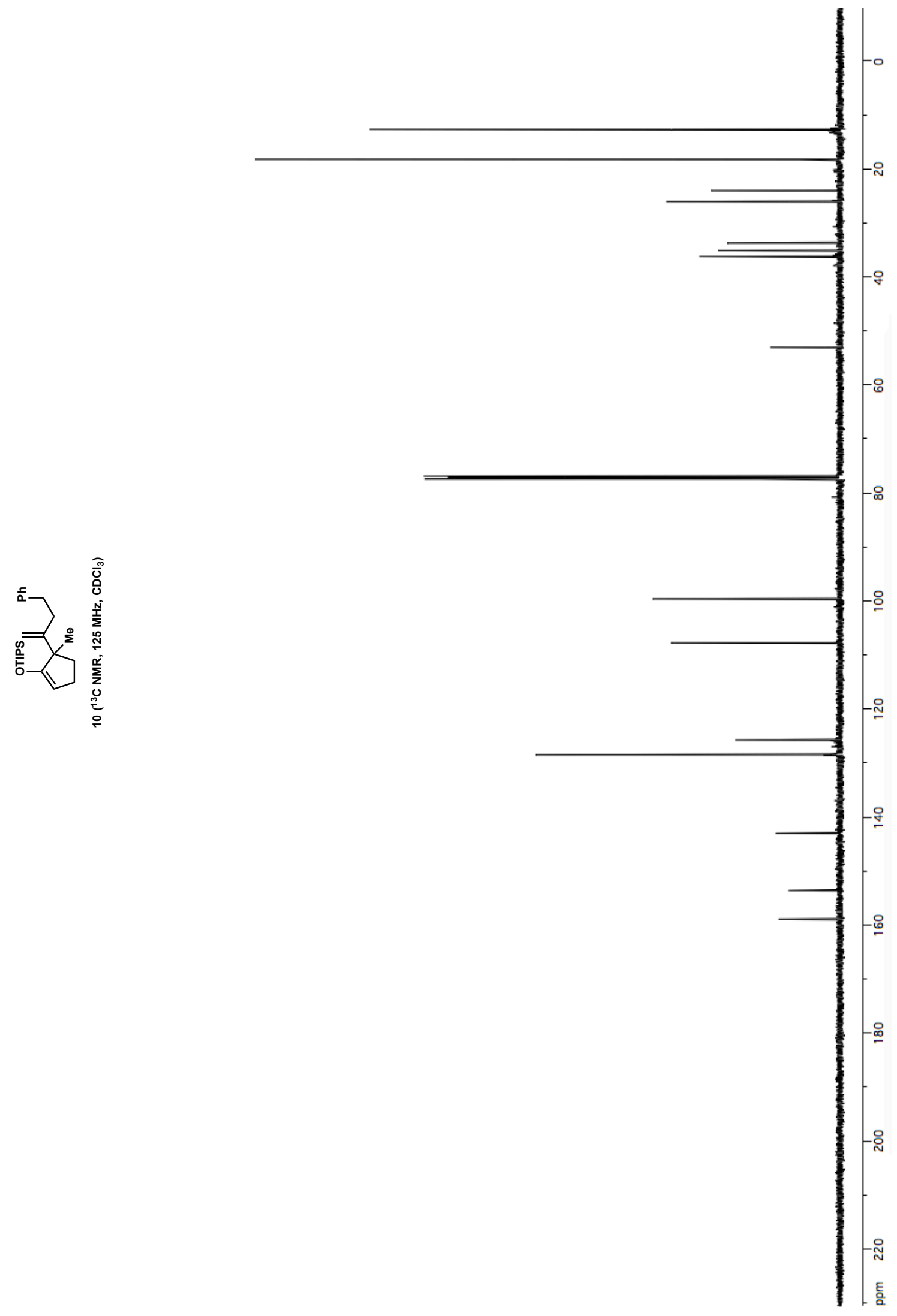


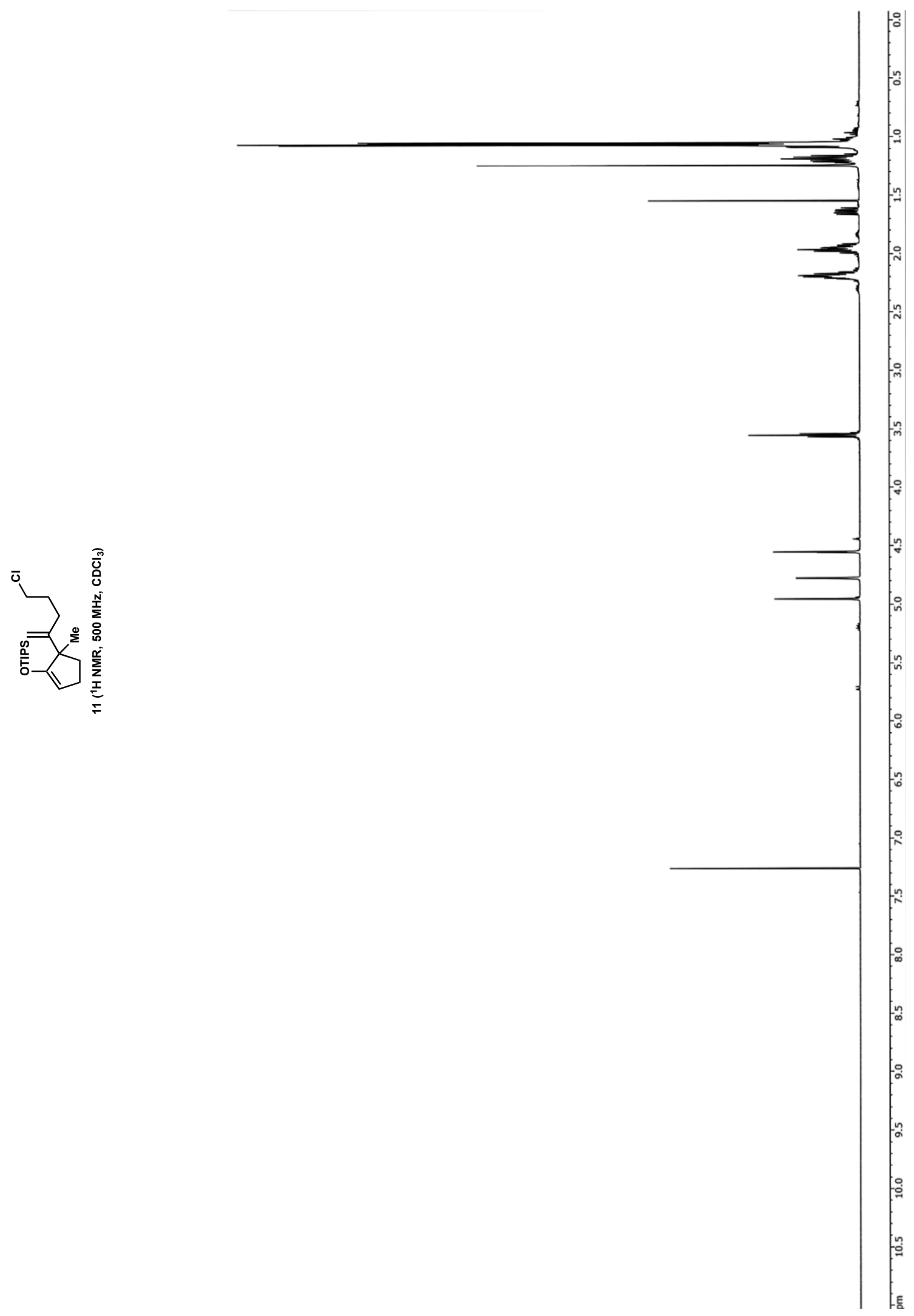




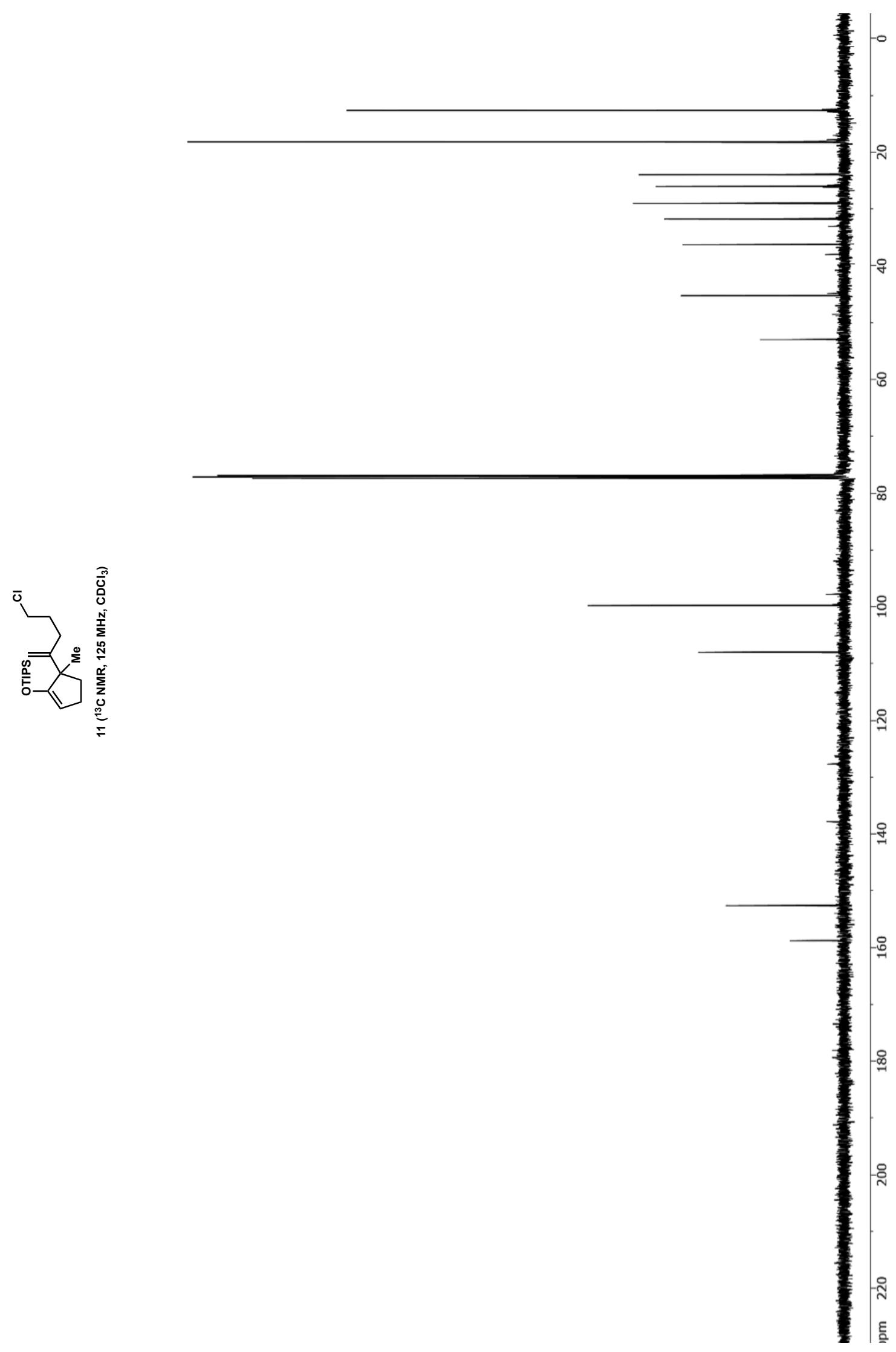




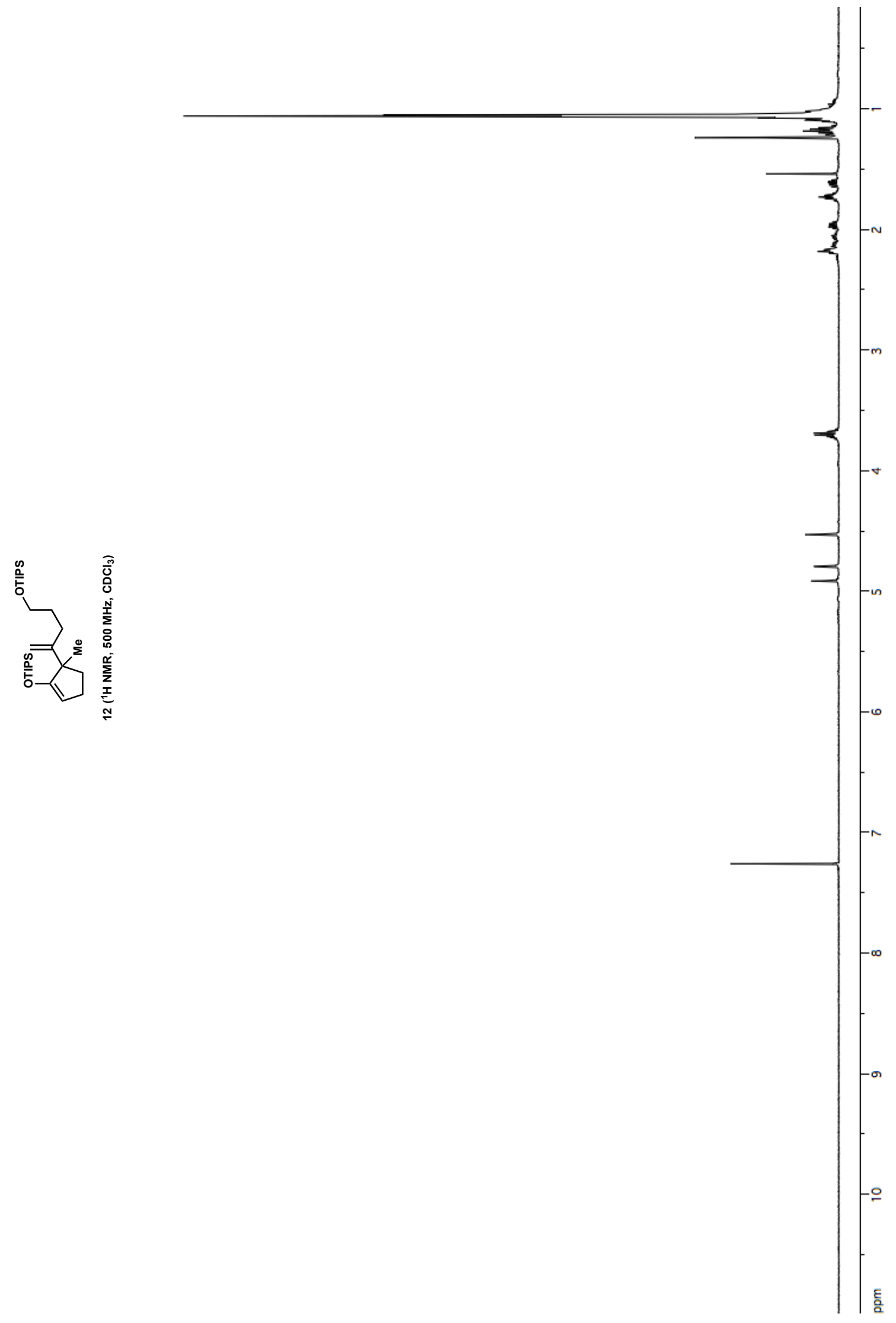



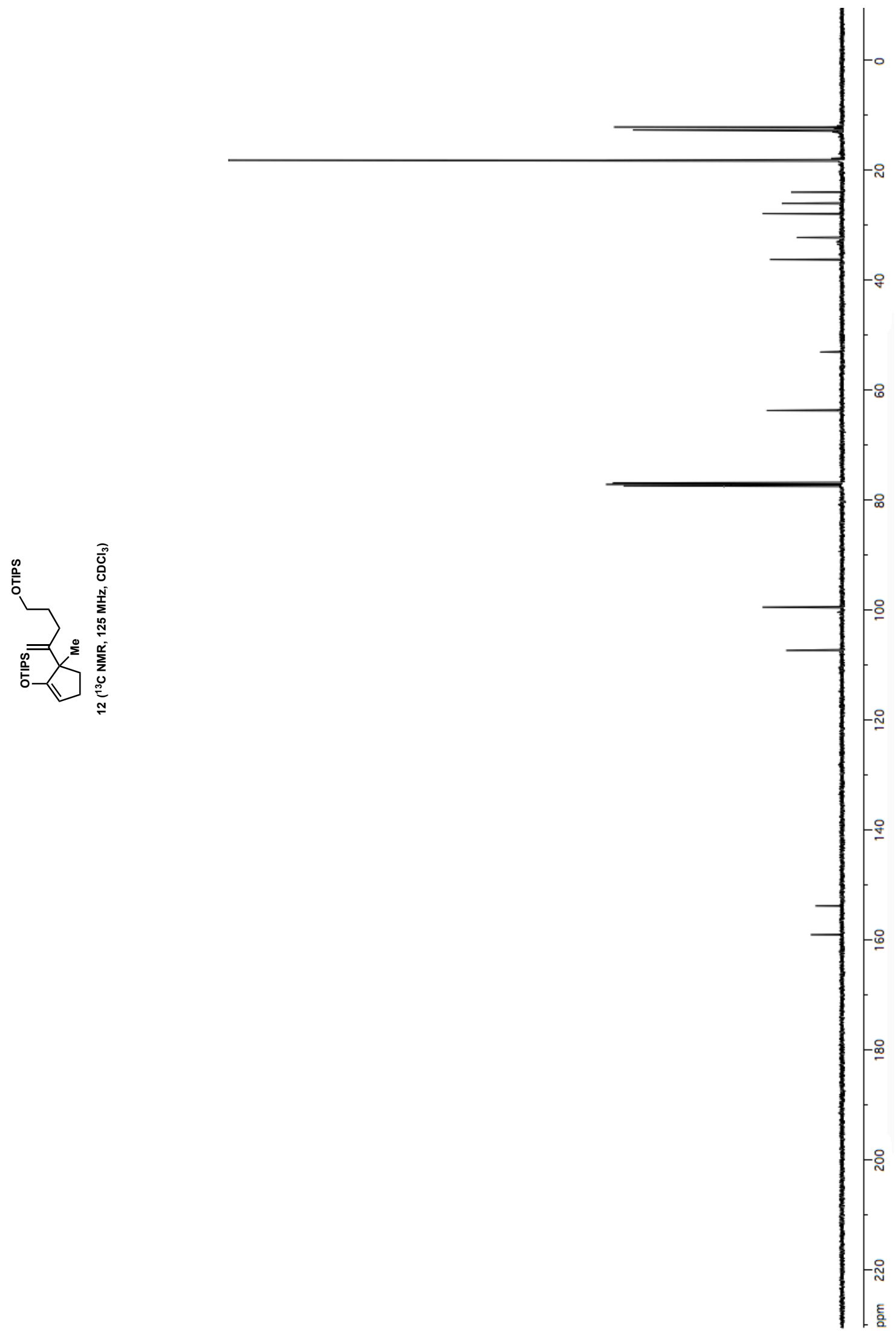

SI 80 


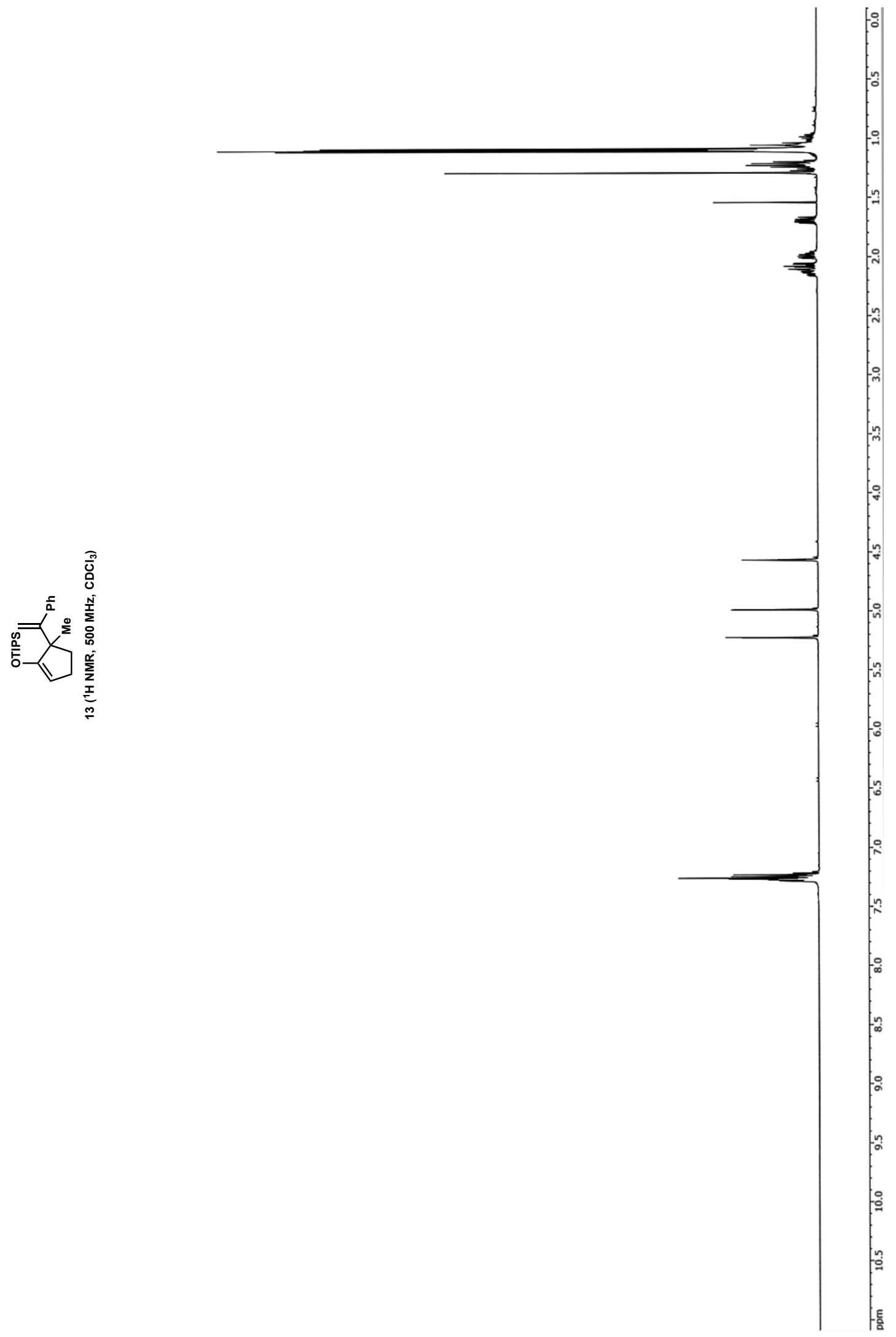




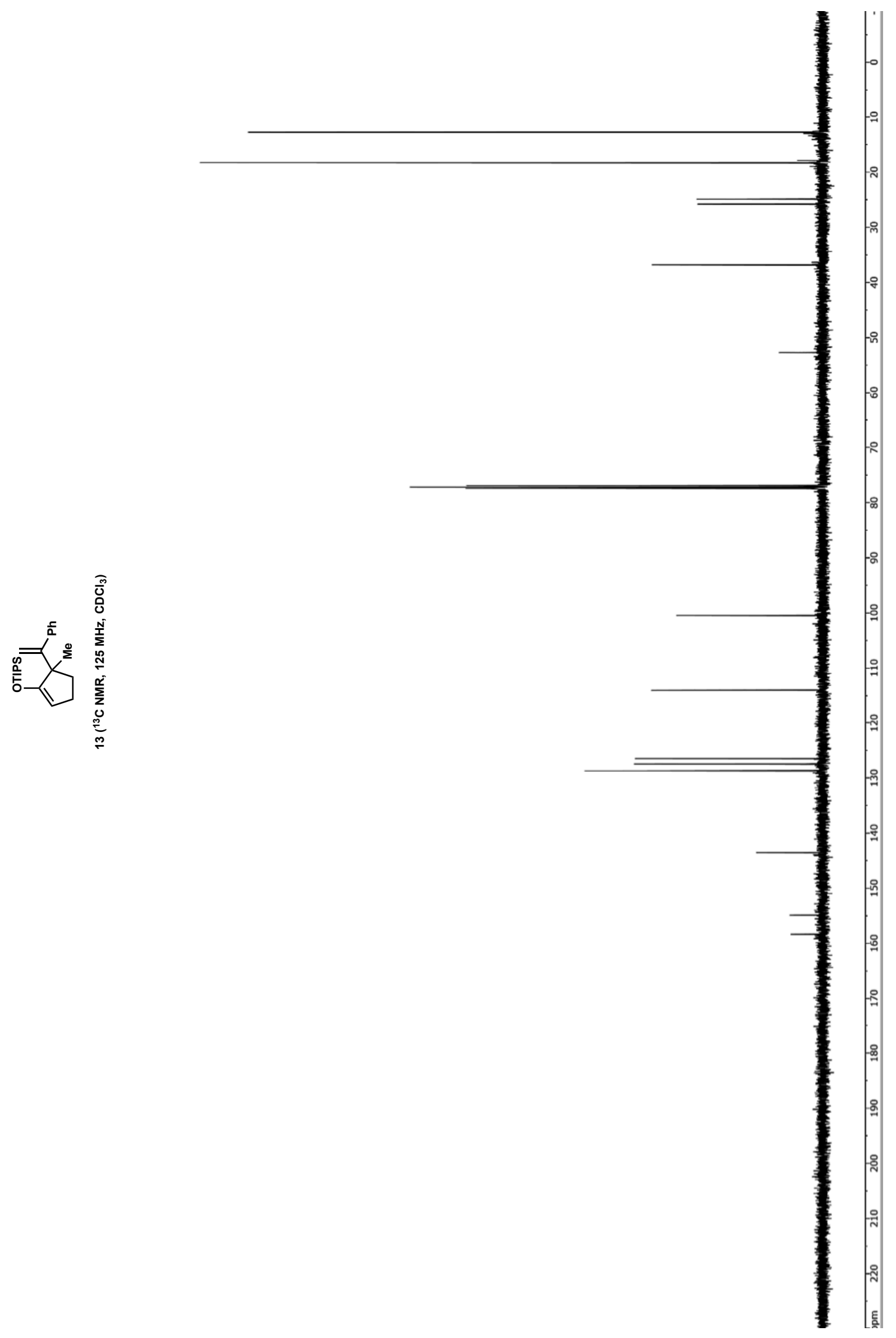

SI 82 


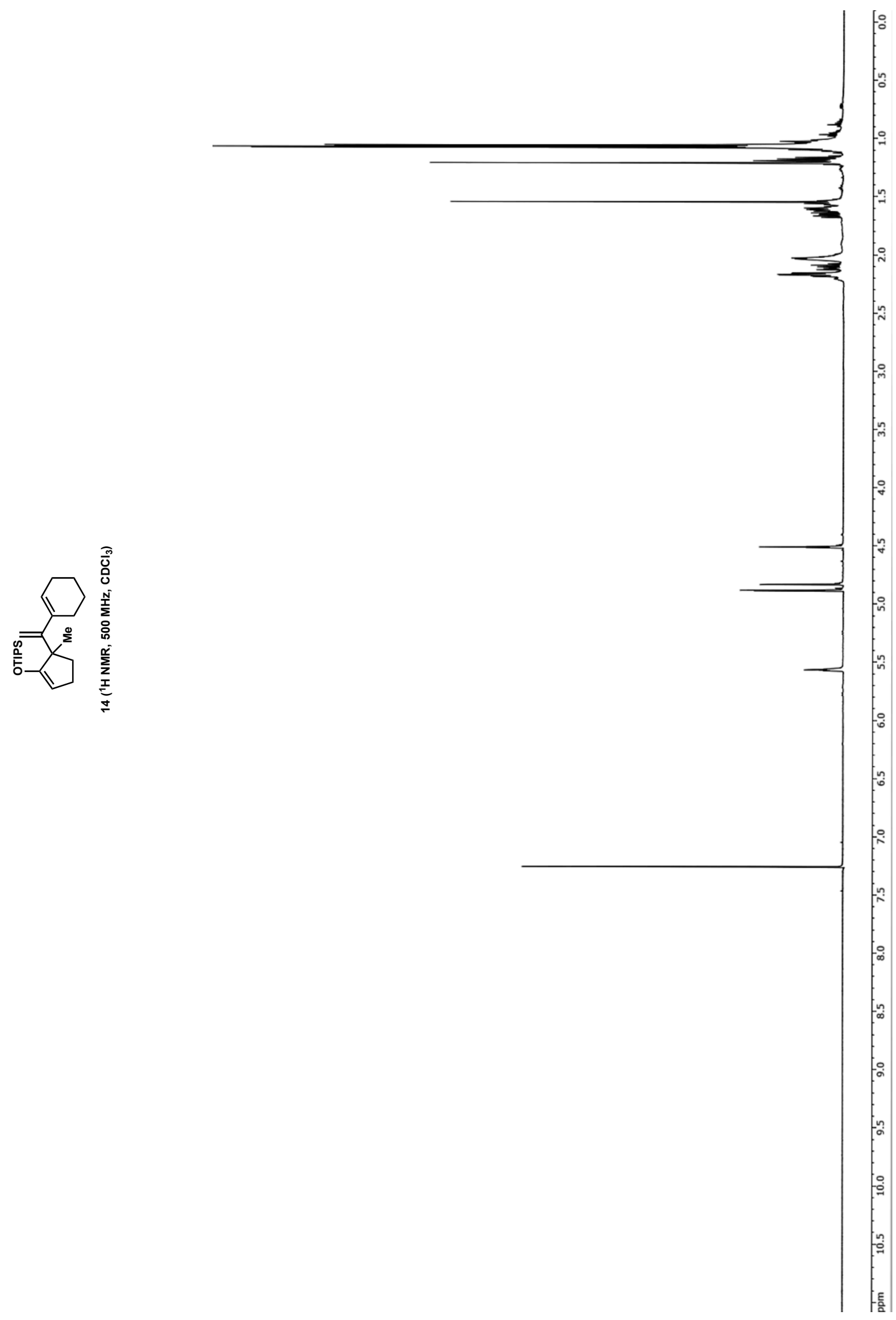




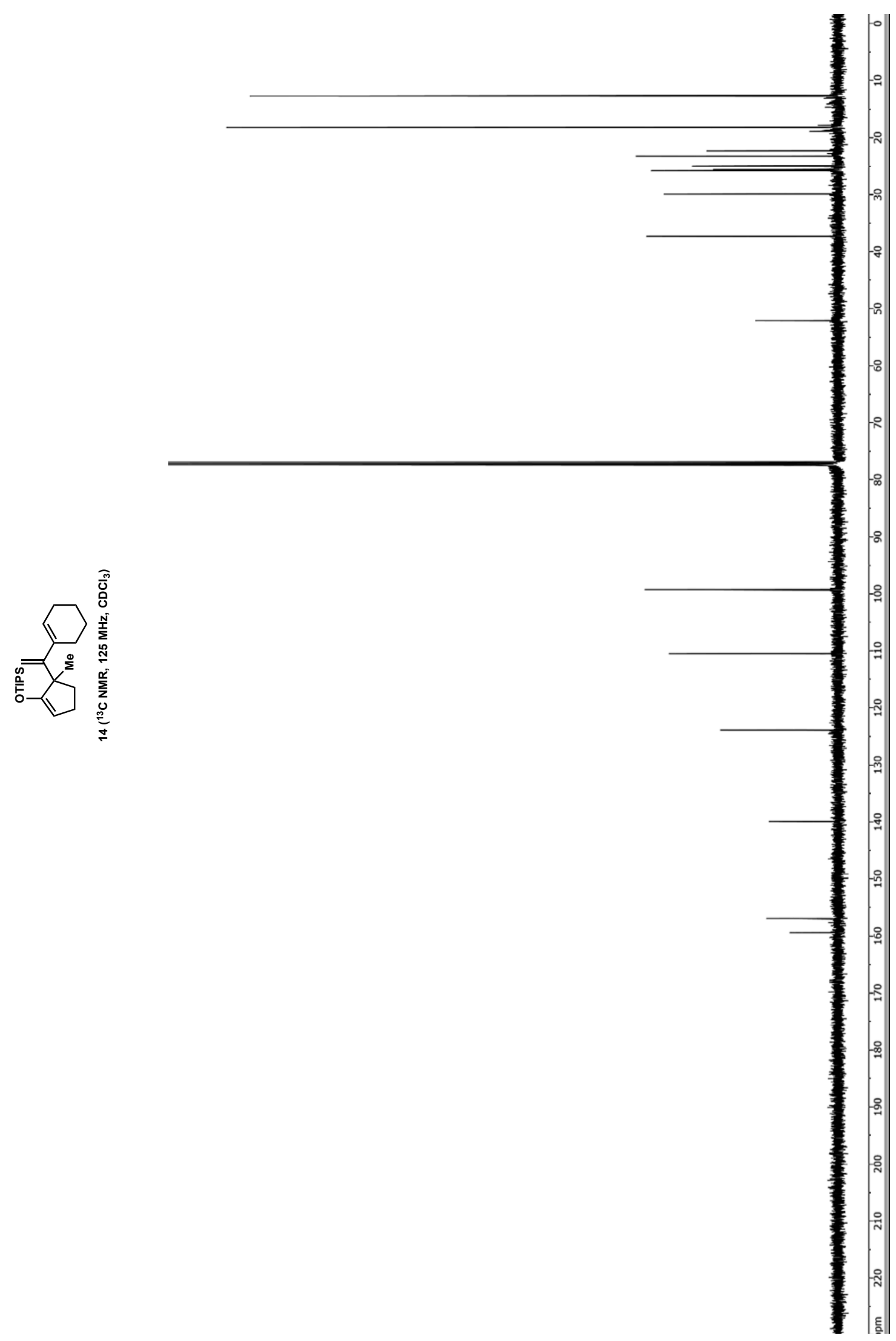

SI 84 


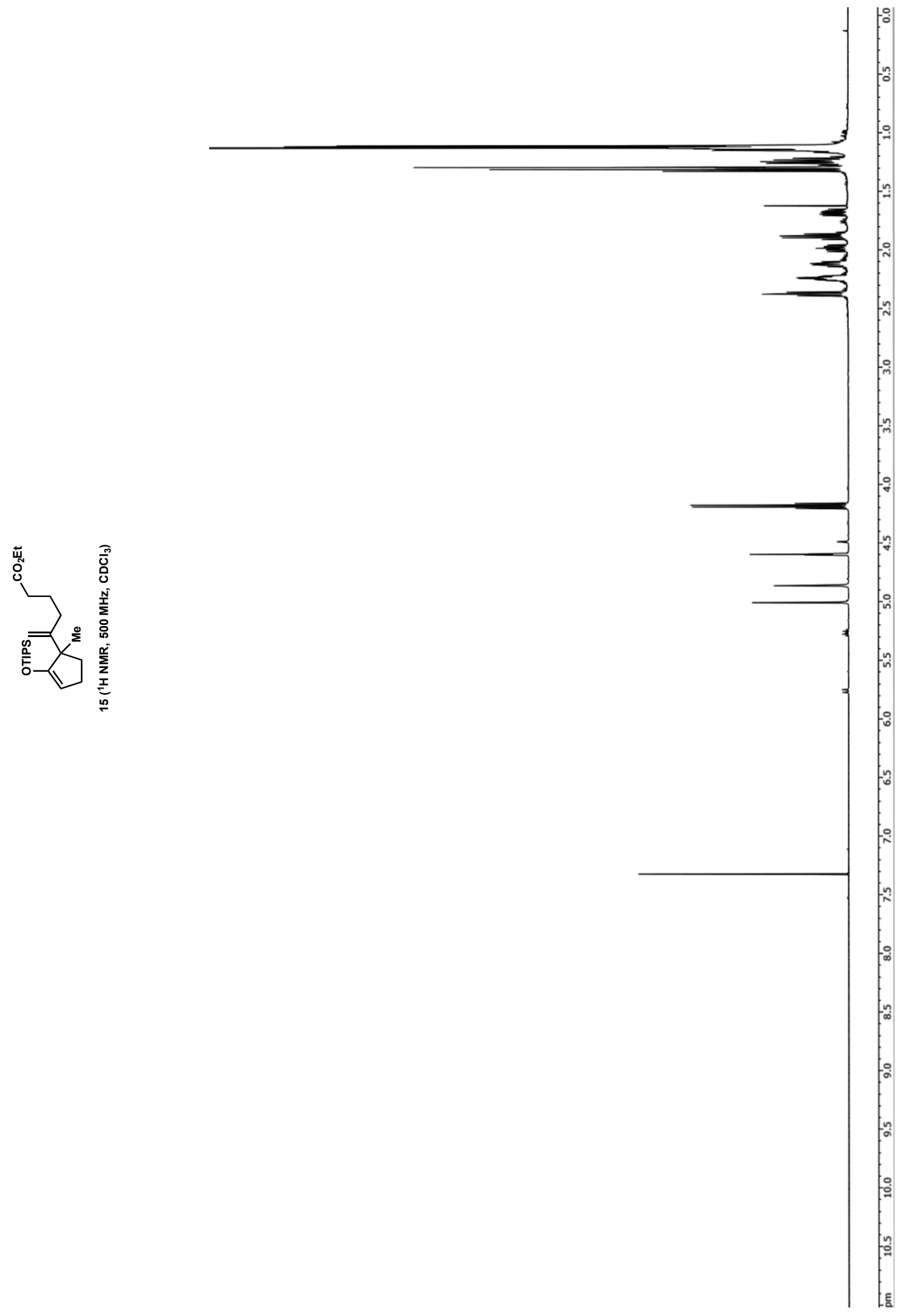




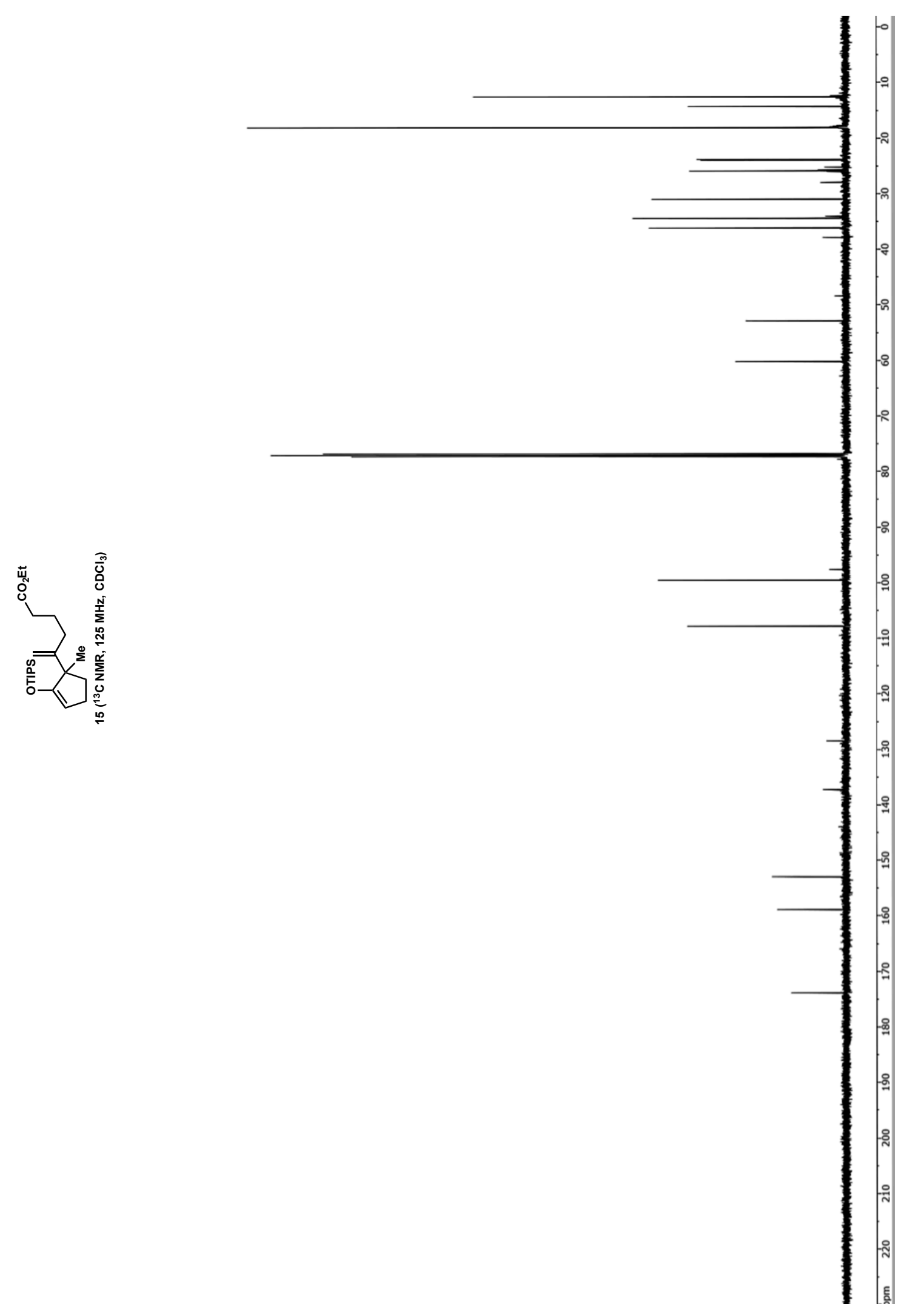

SI 86 


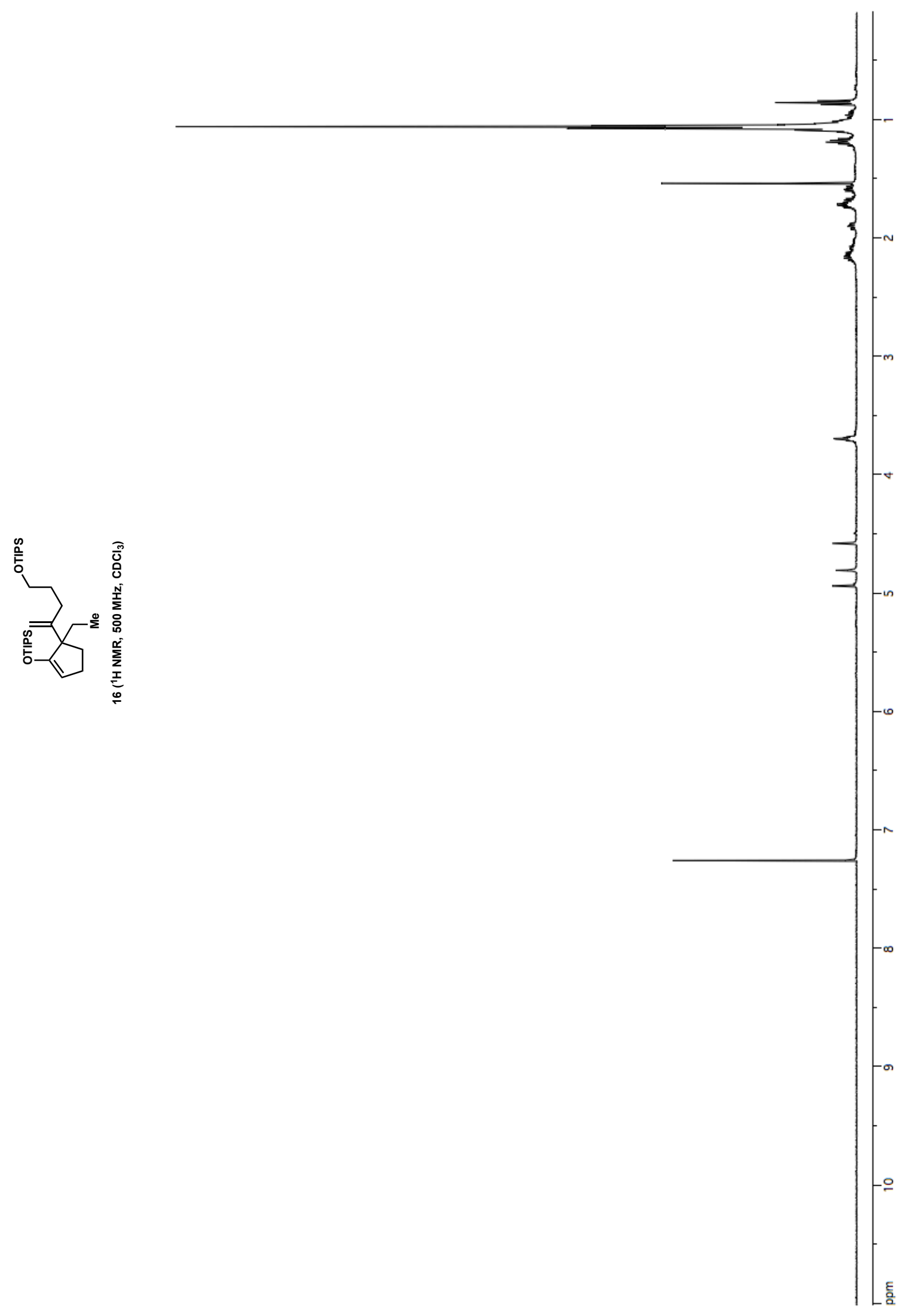




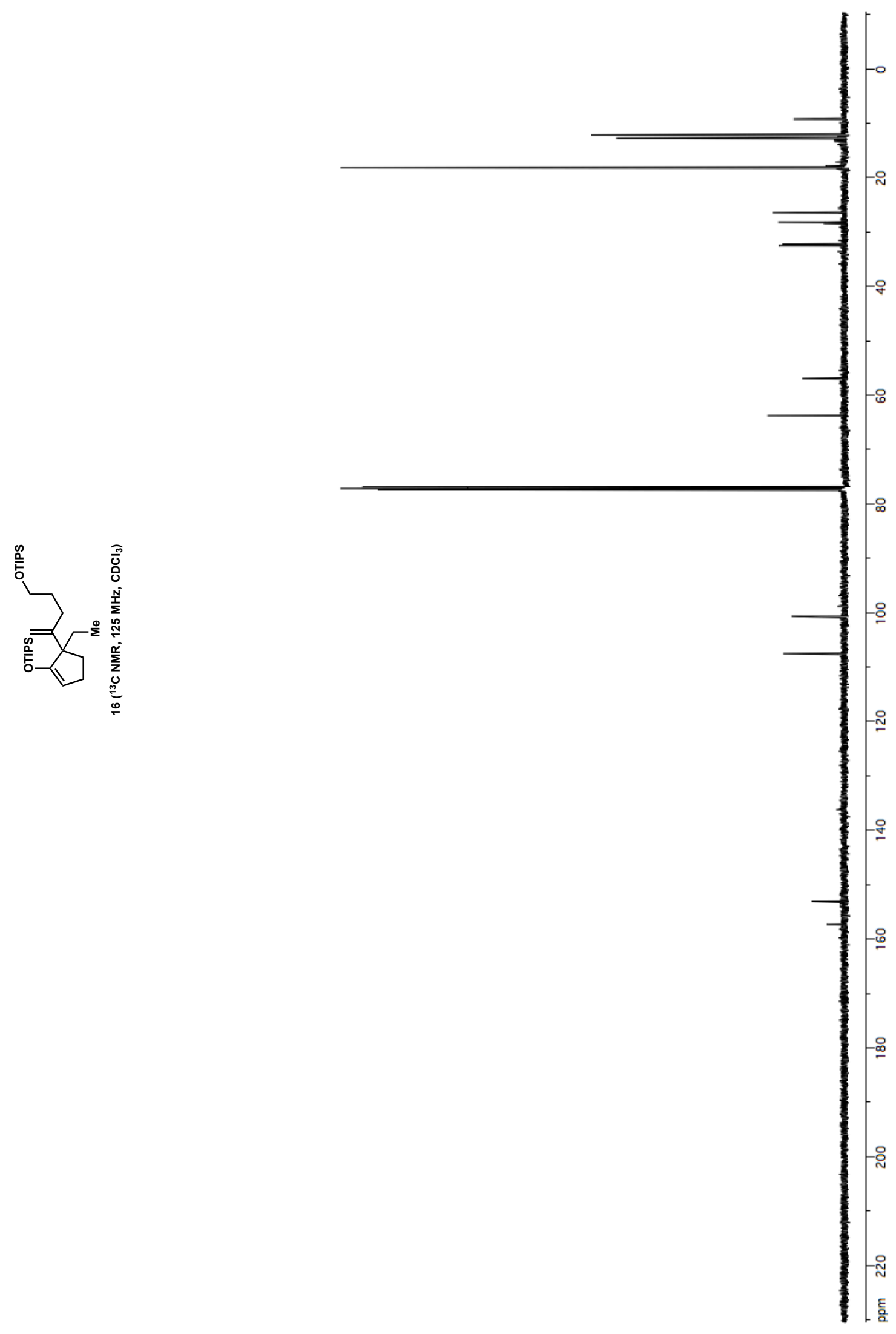

SI 88 


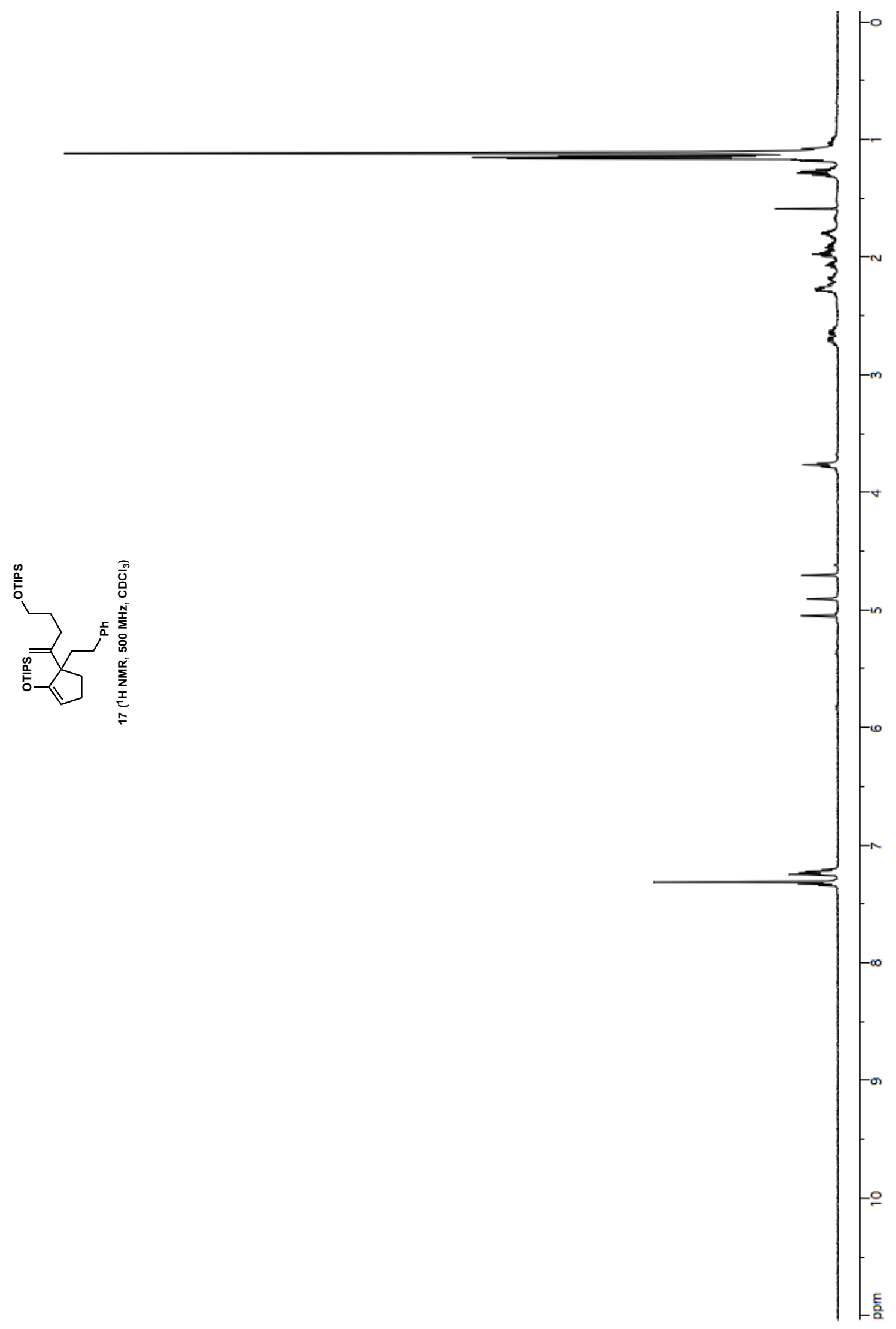




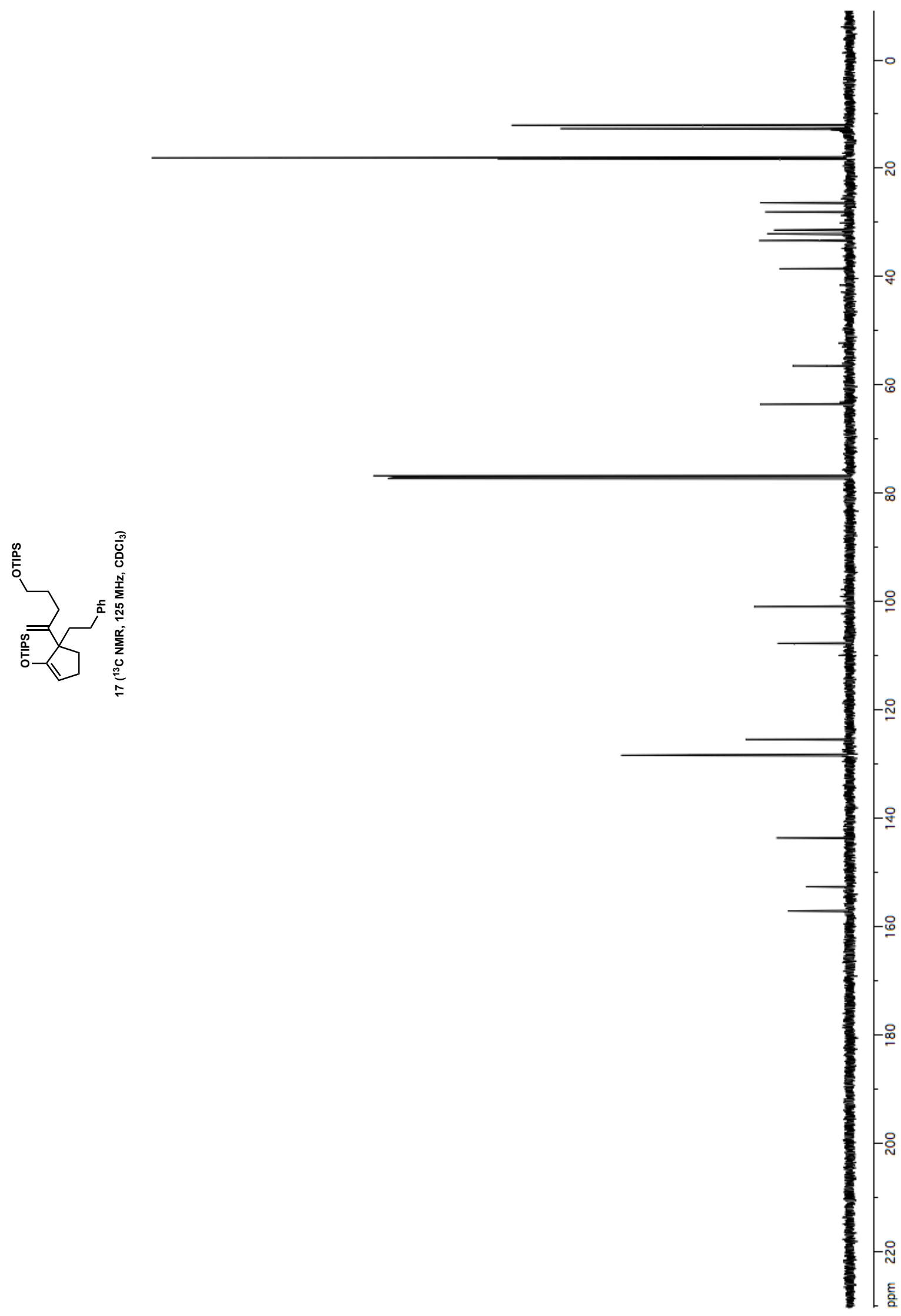

SI 90 


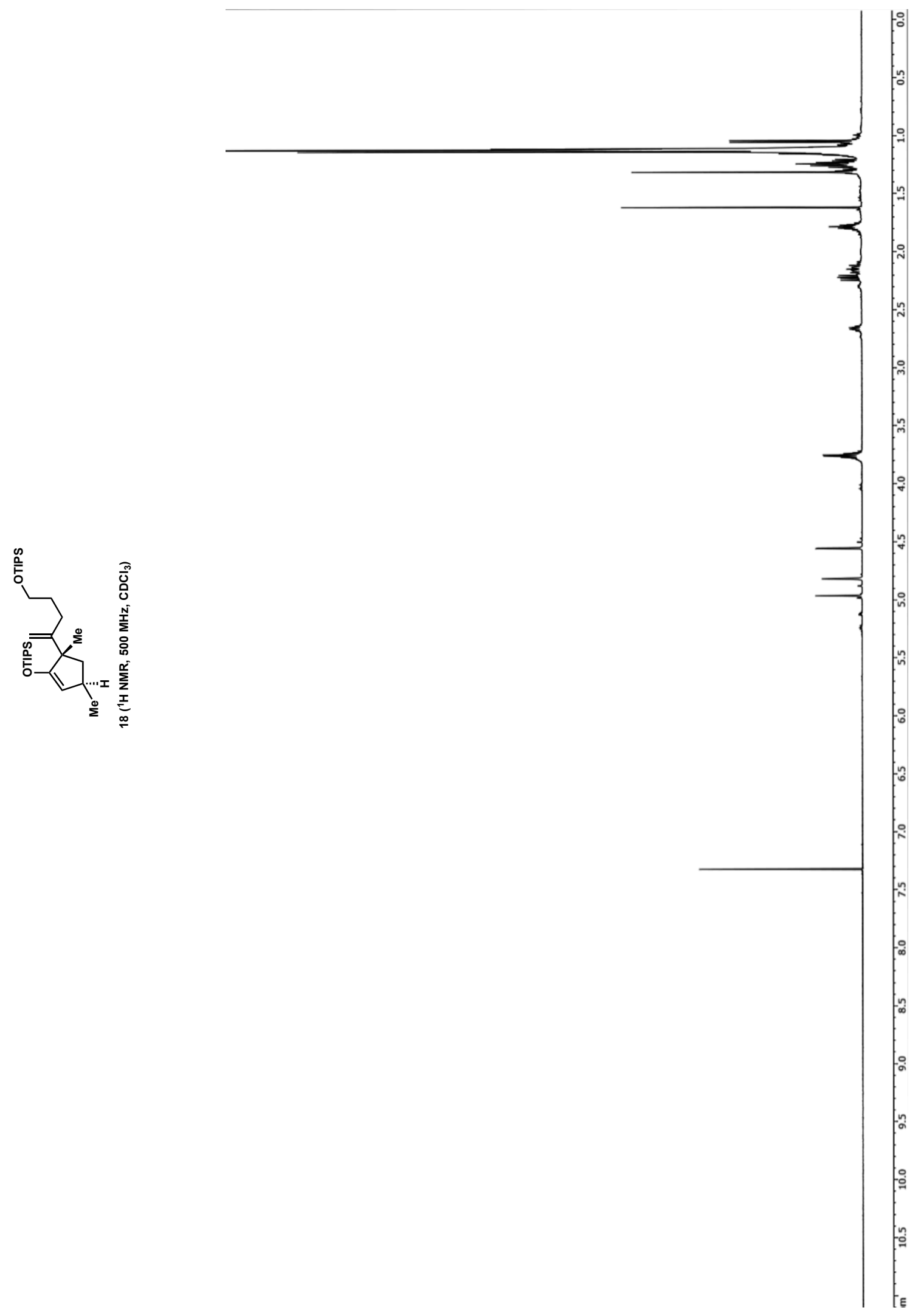




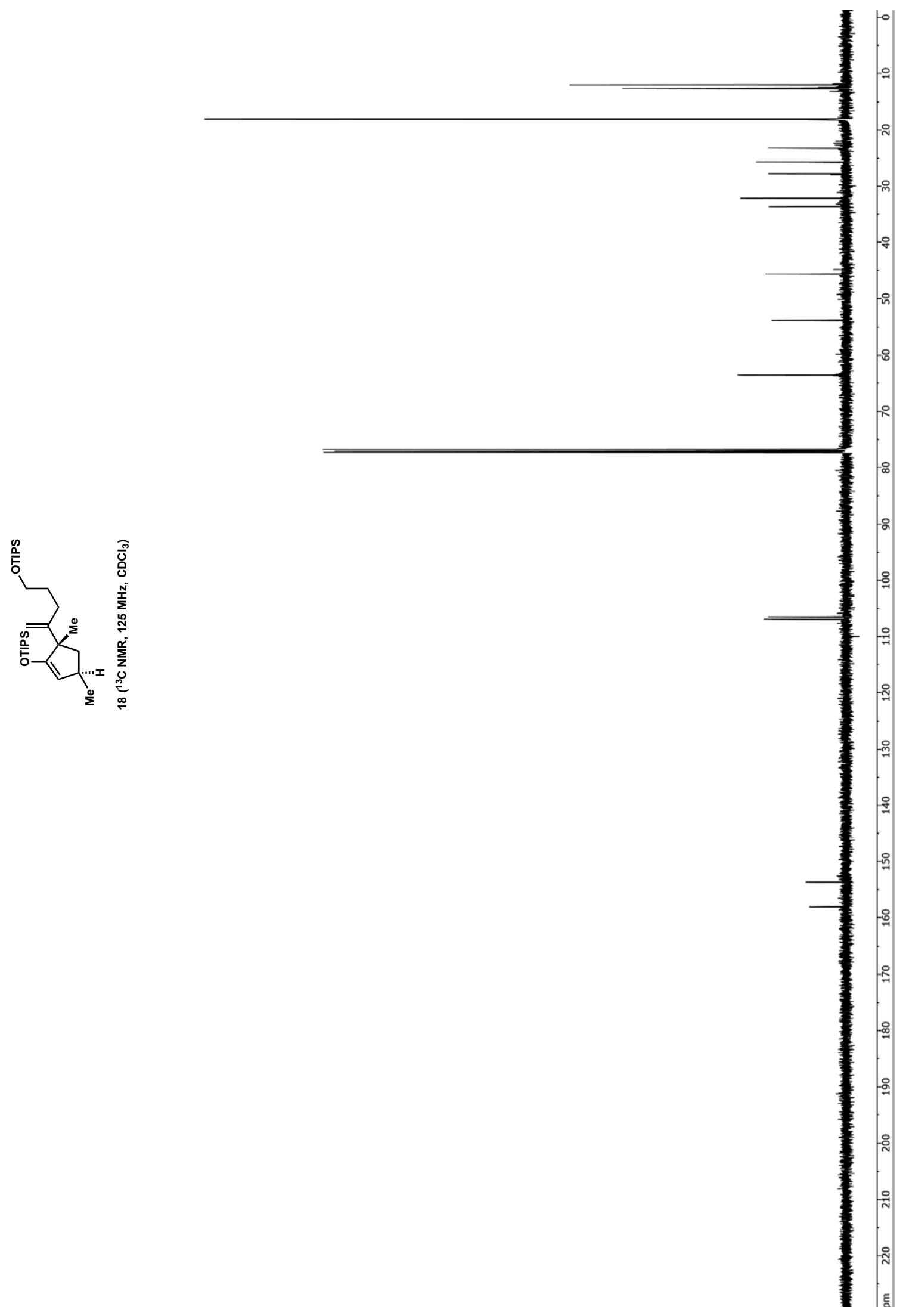

SI 92 


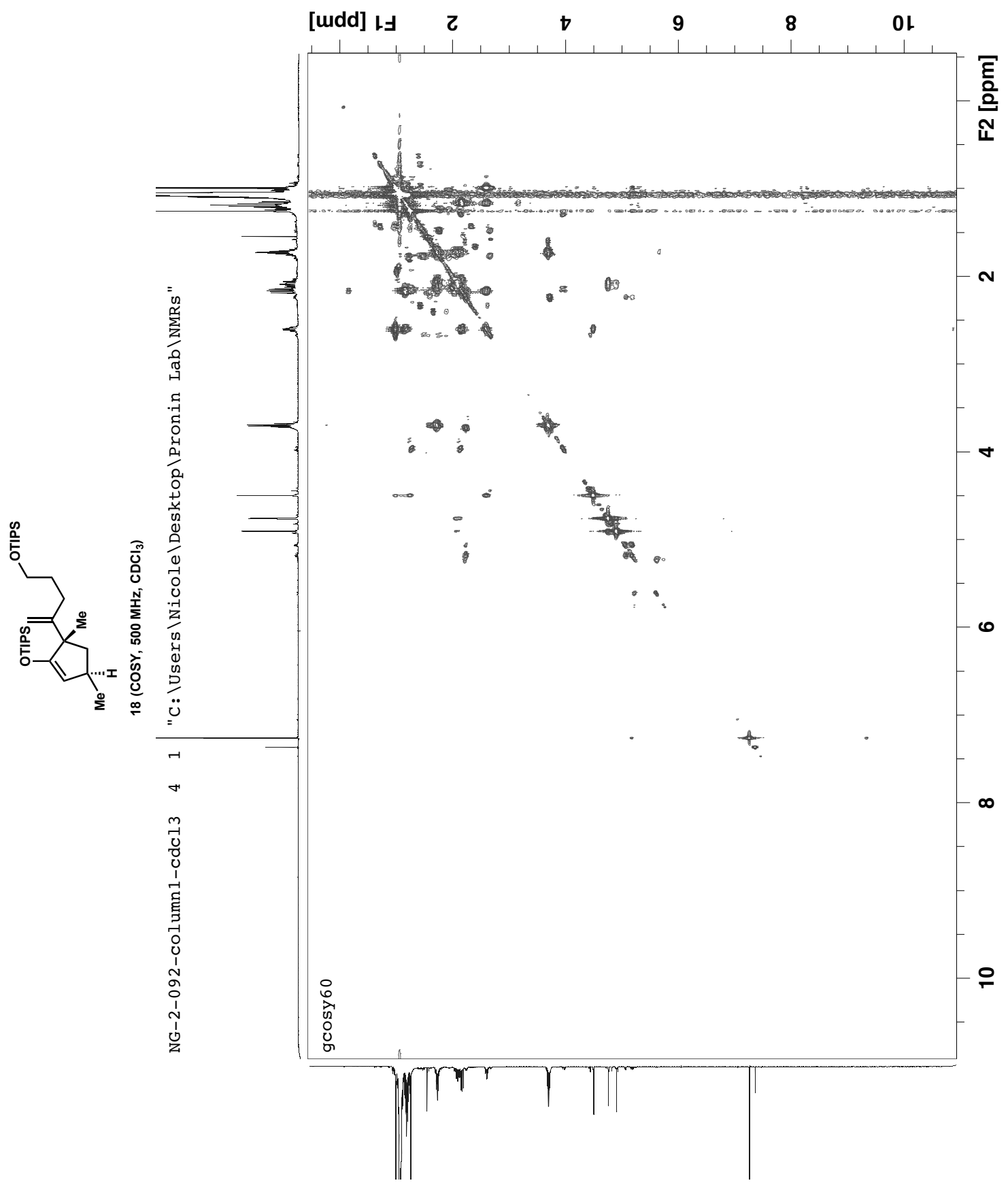




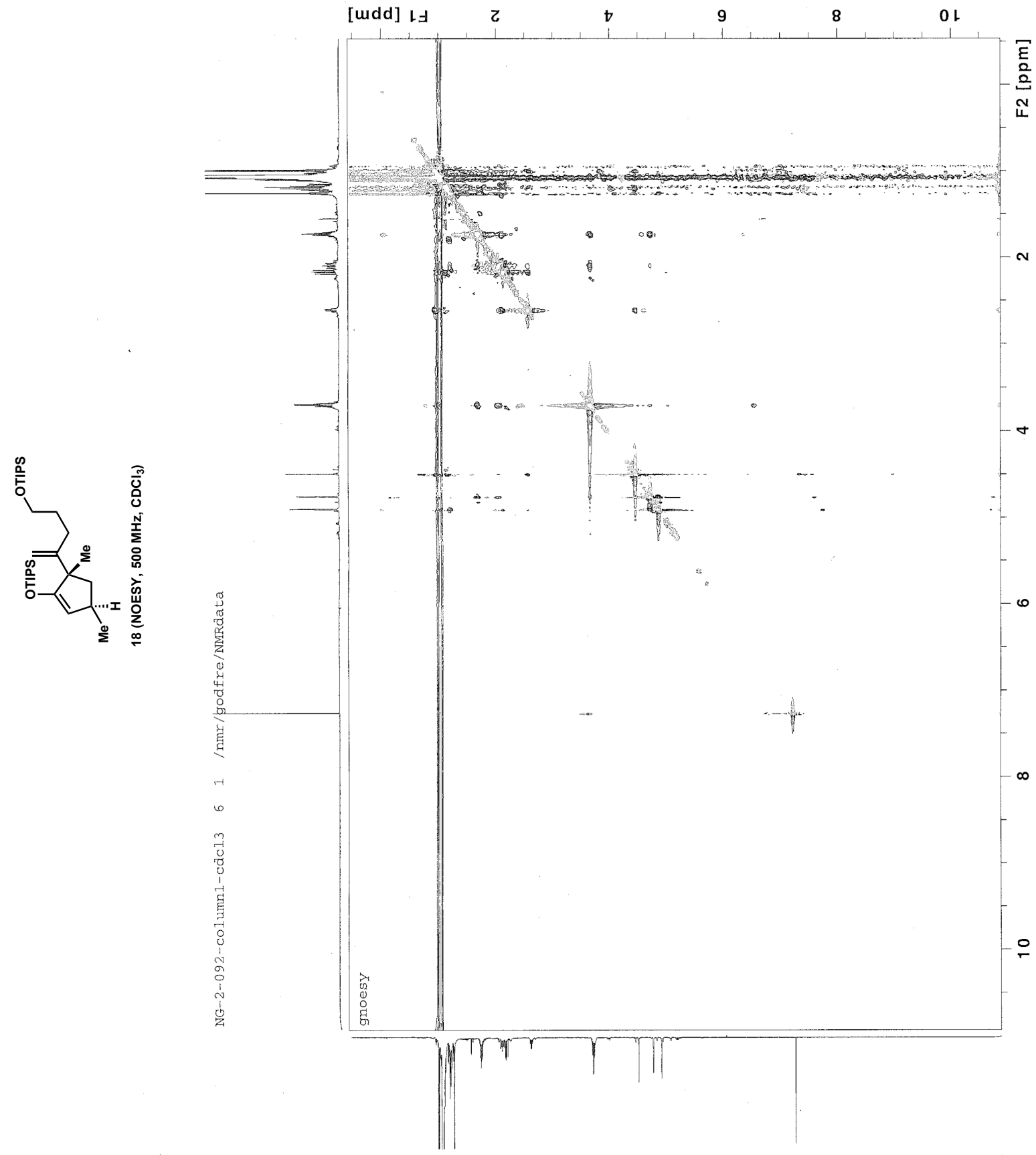




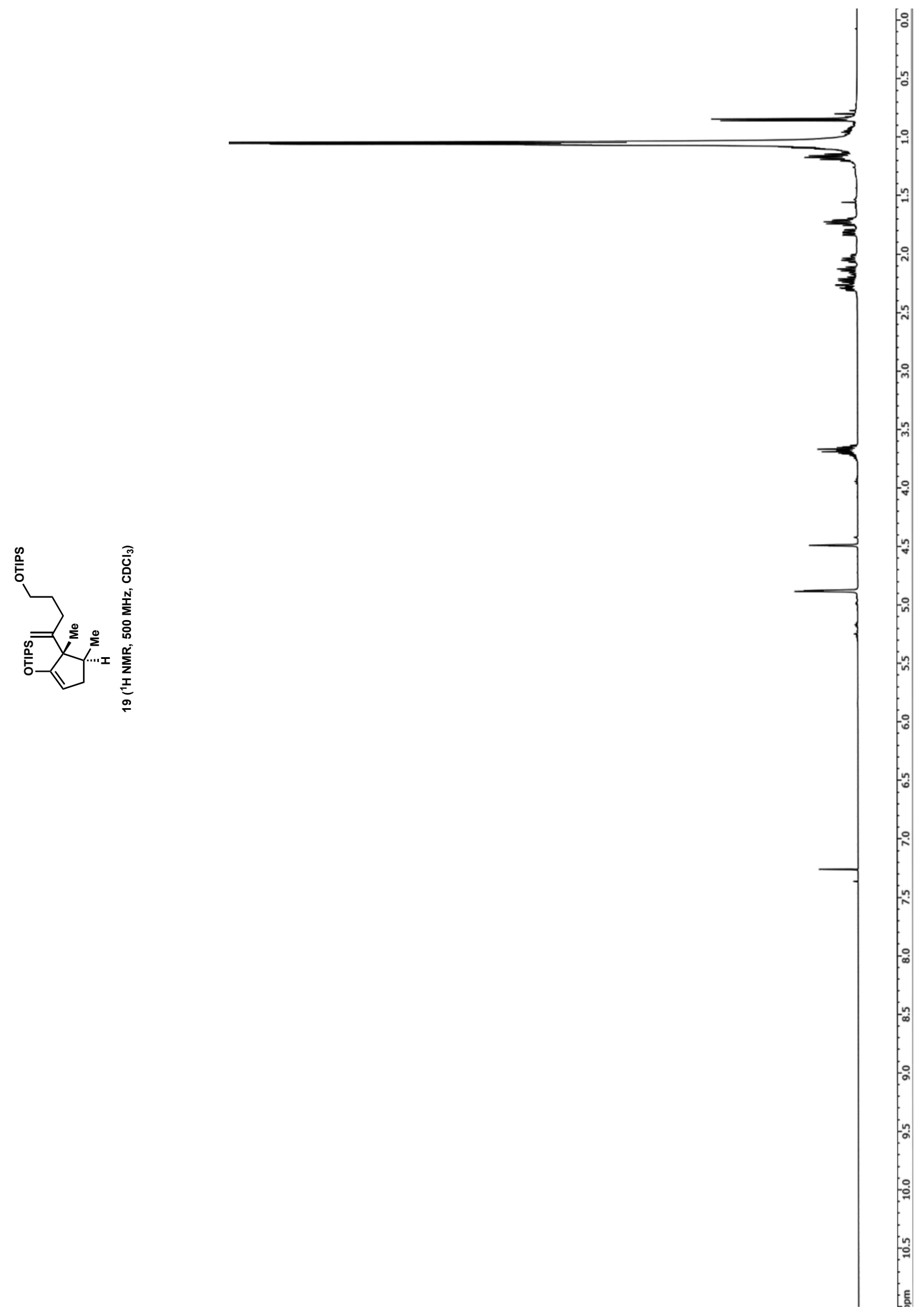




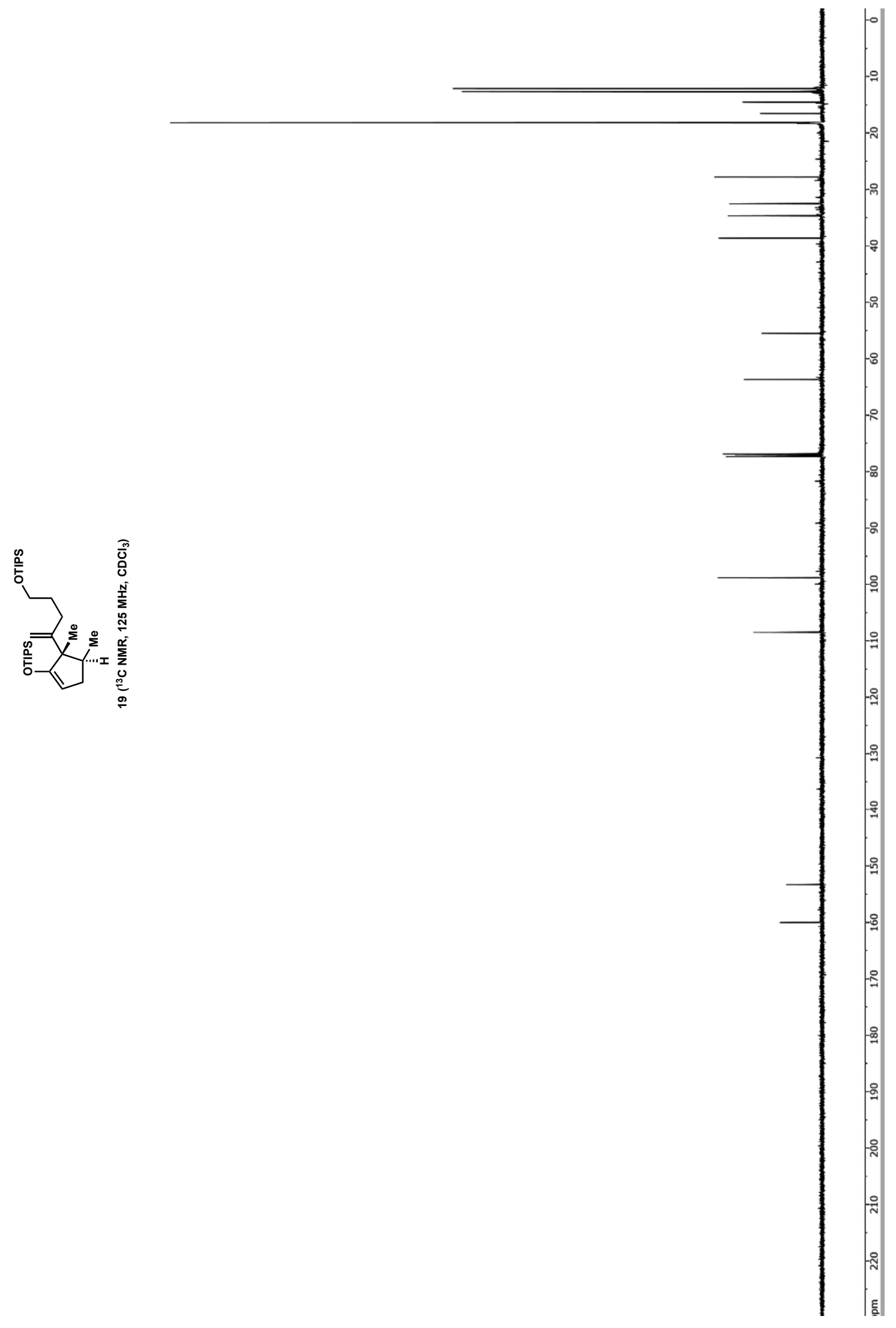




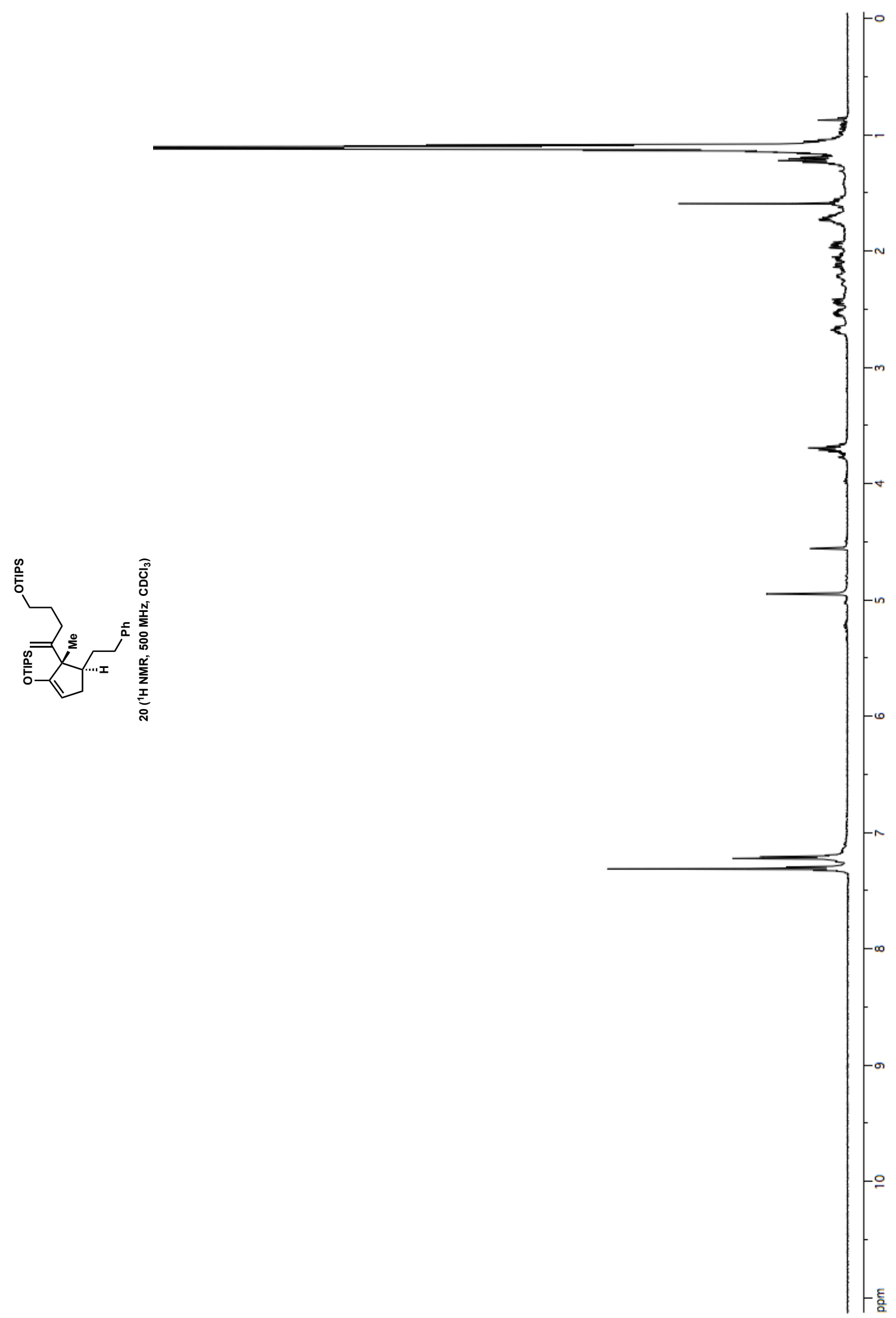




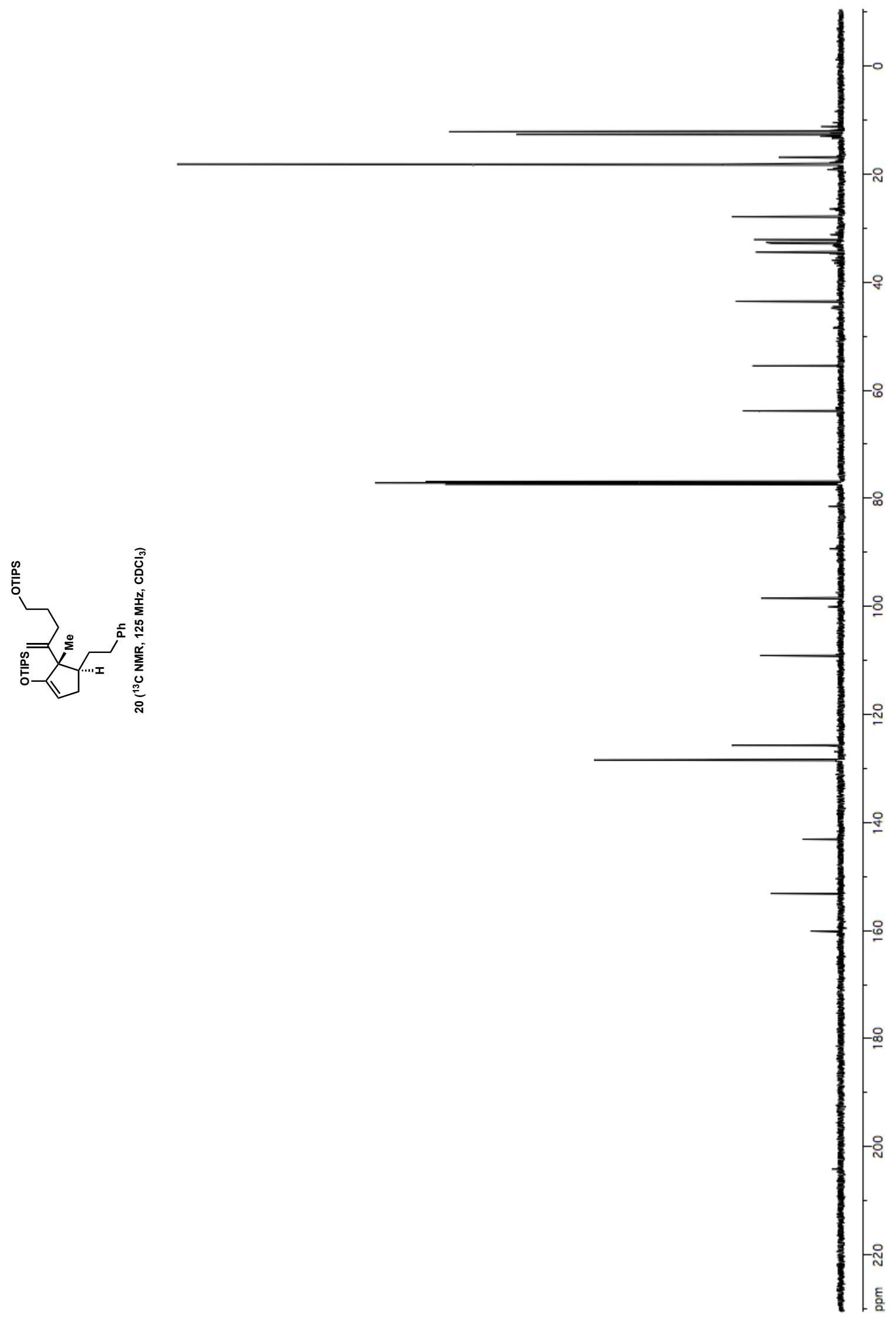




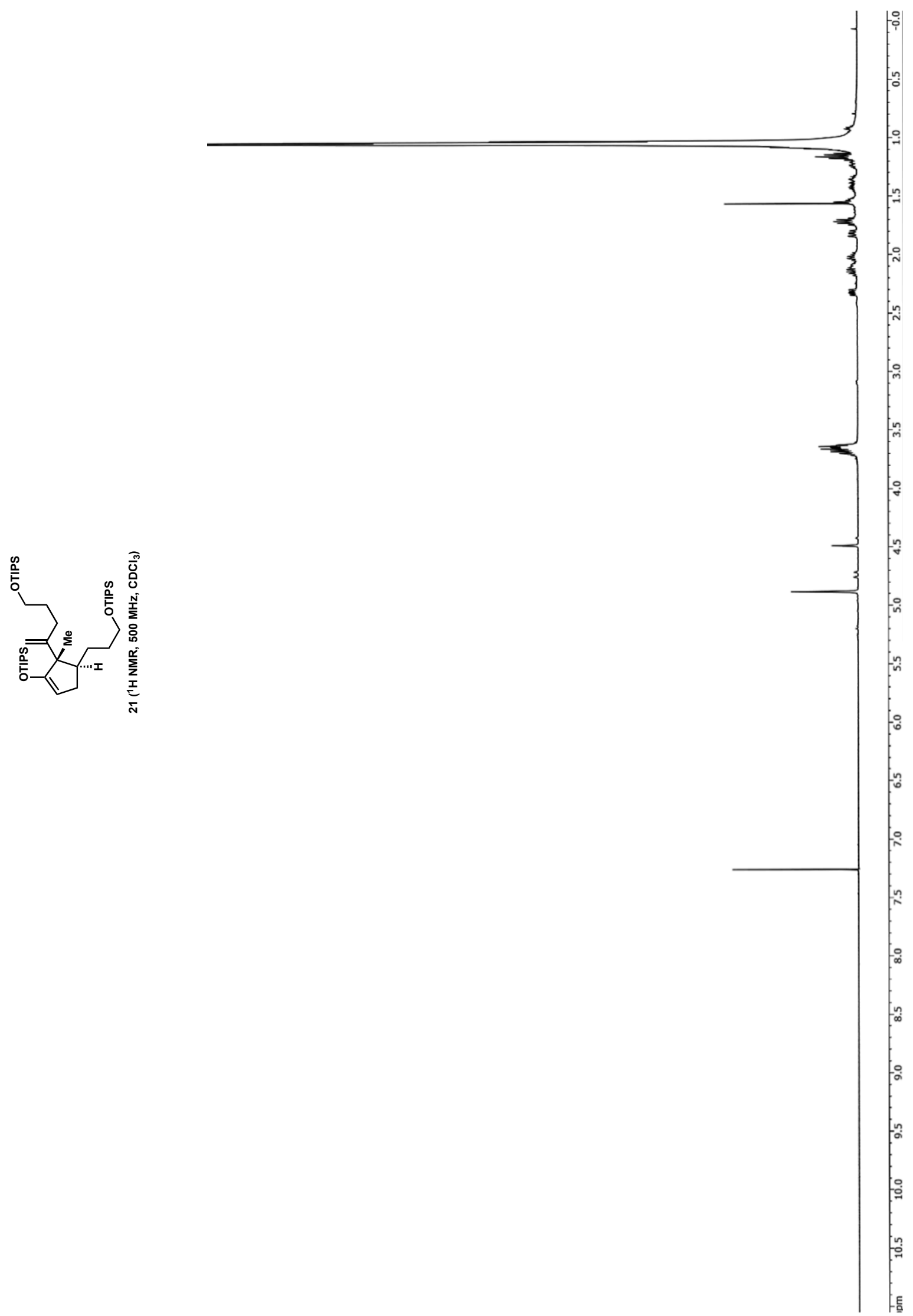




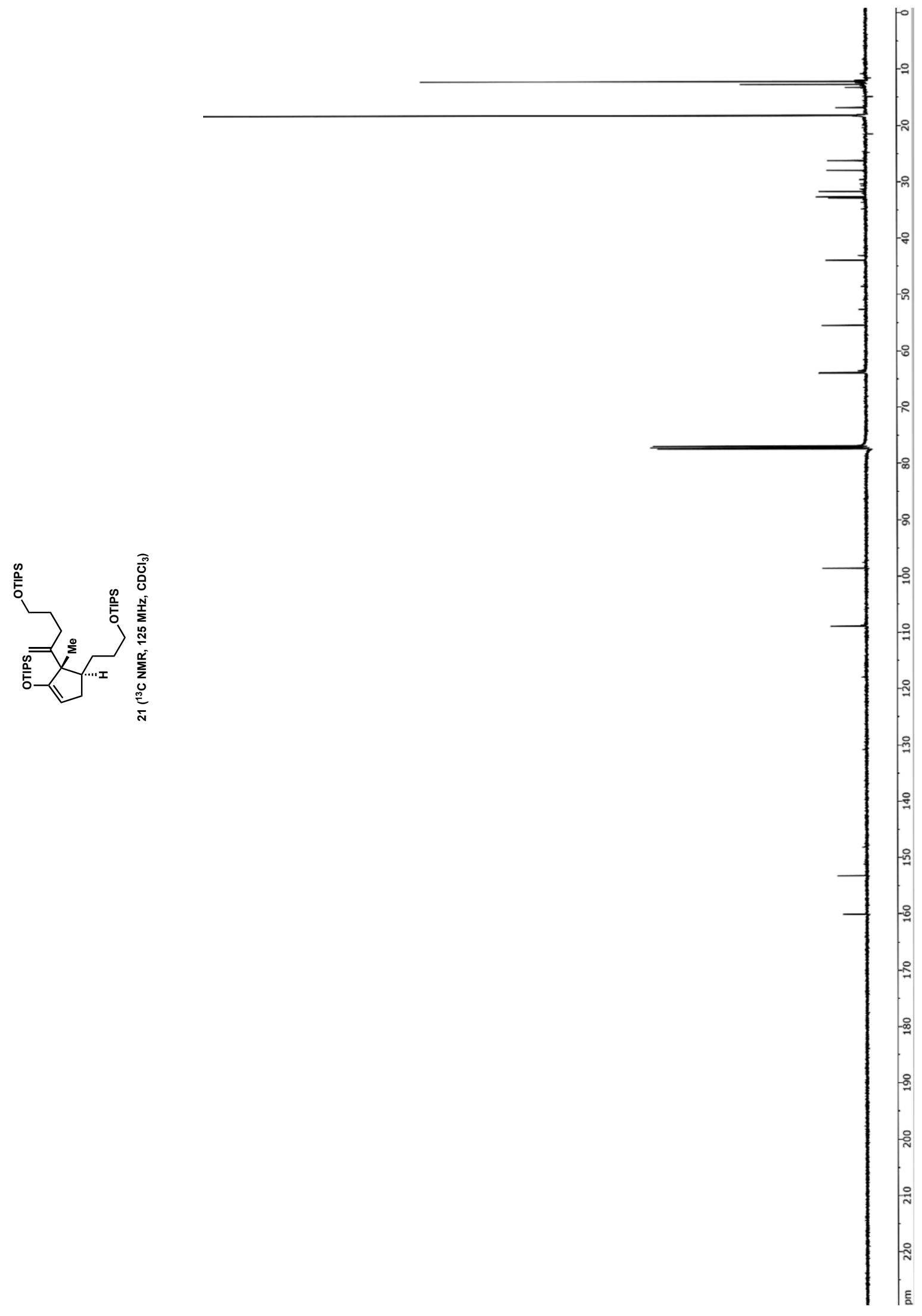

SI 100 


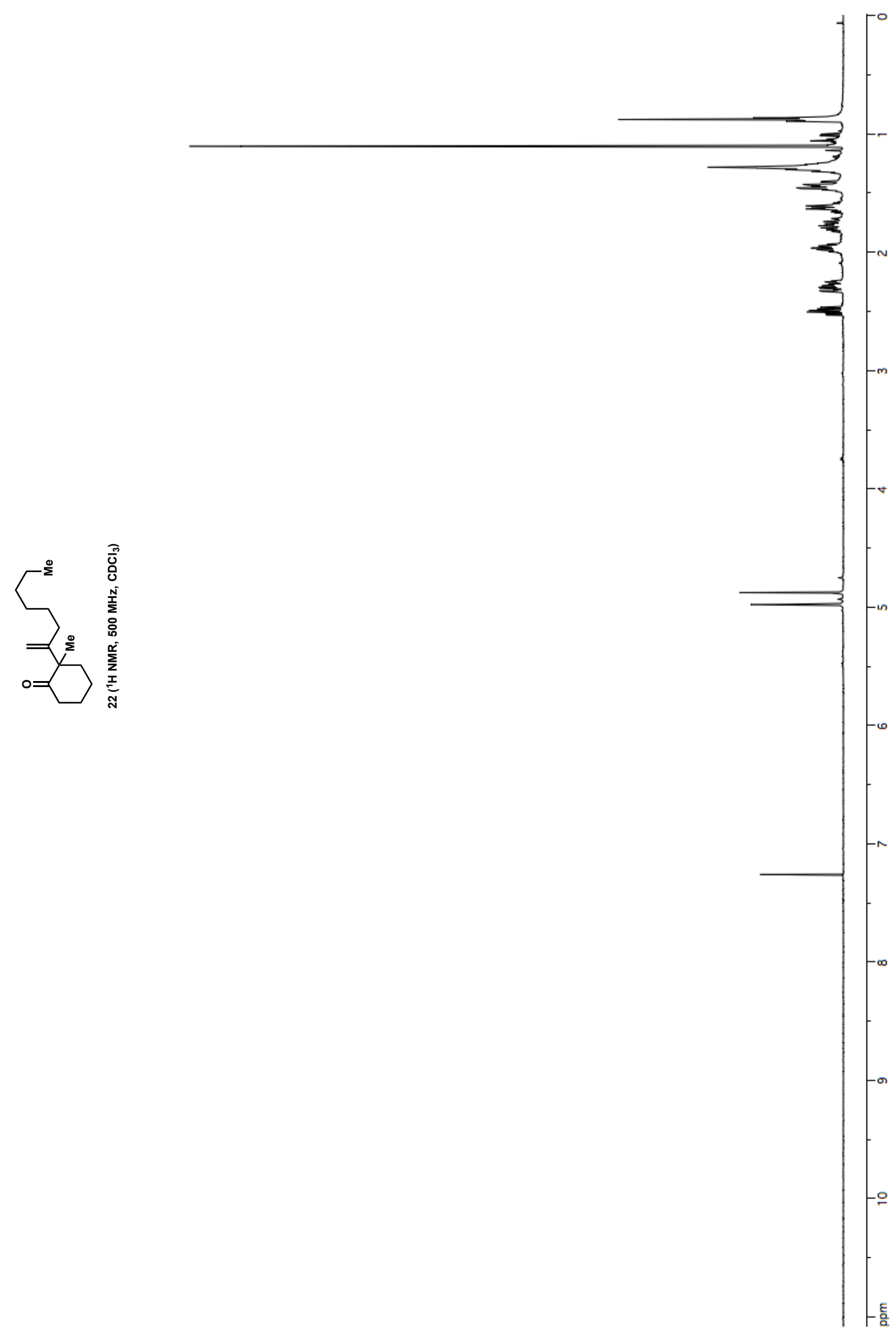

SI 101 

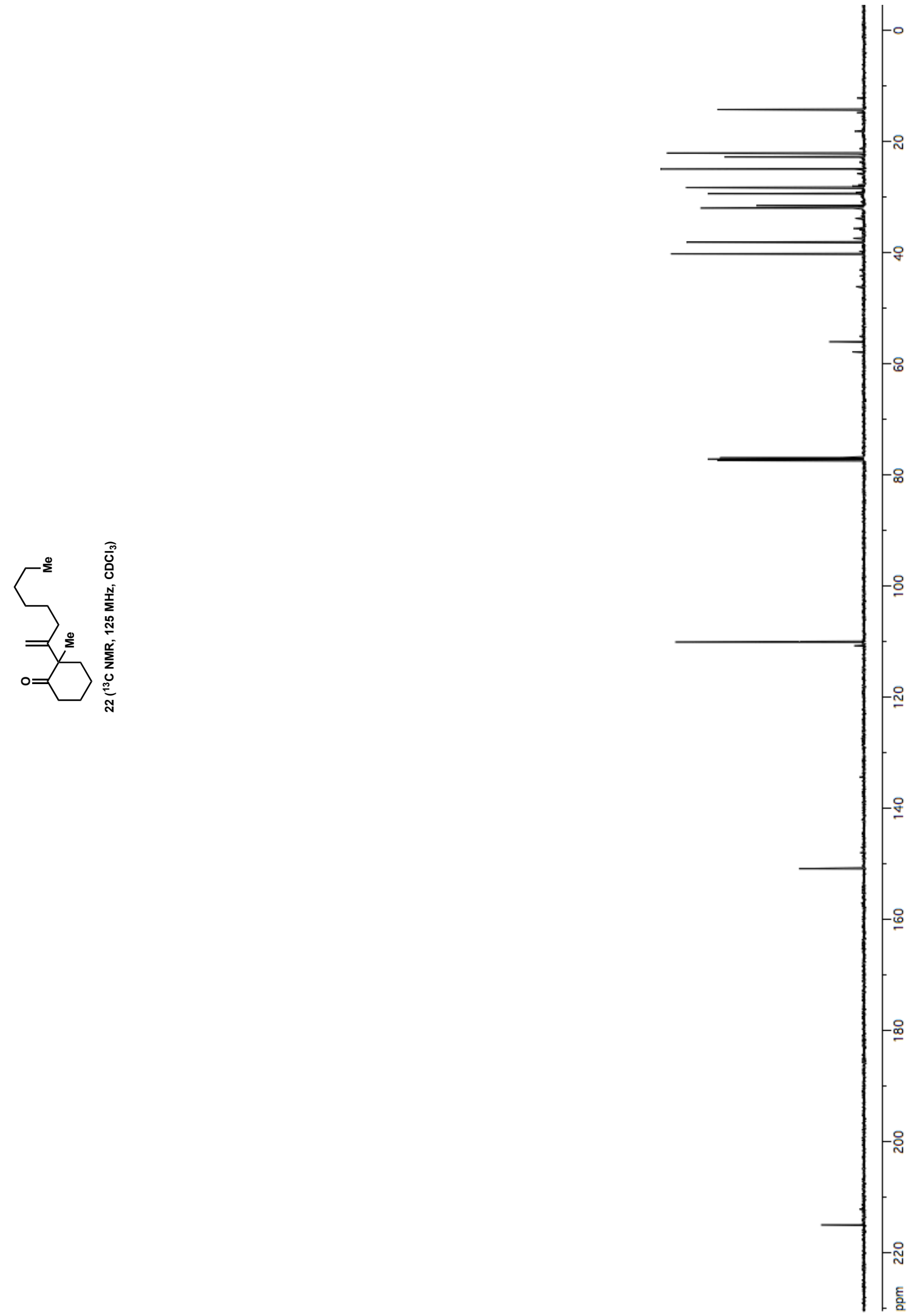

SI 102 


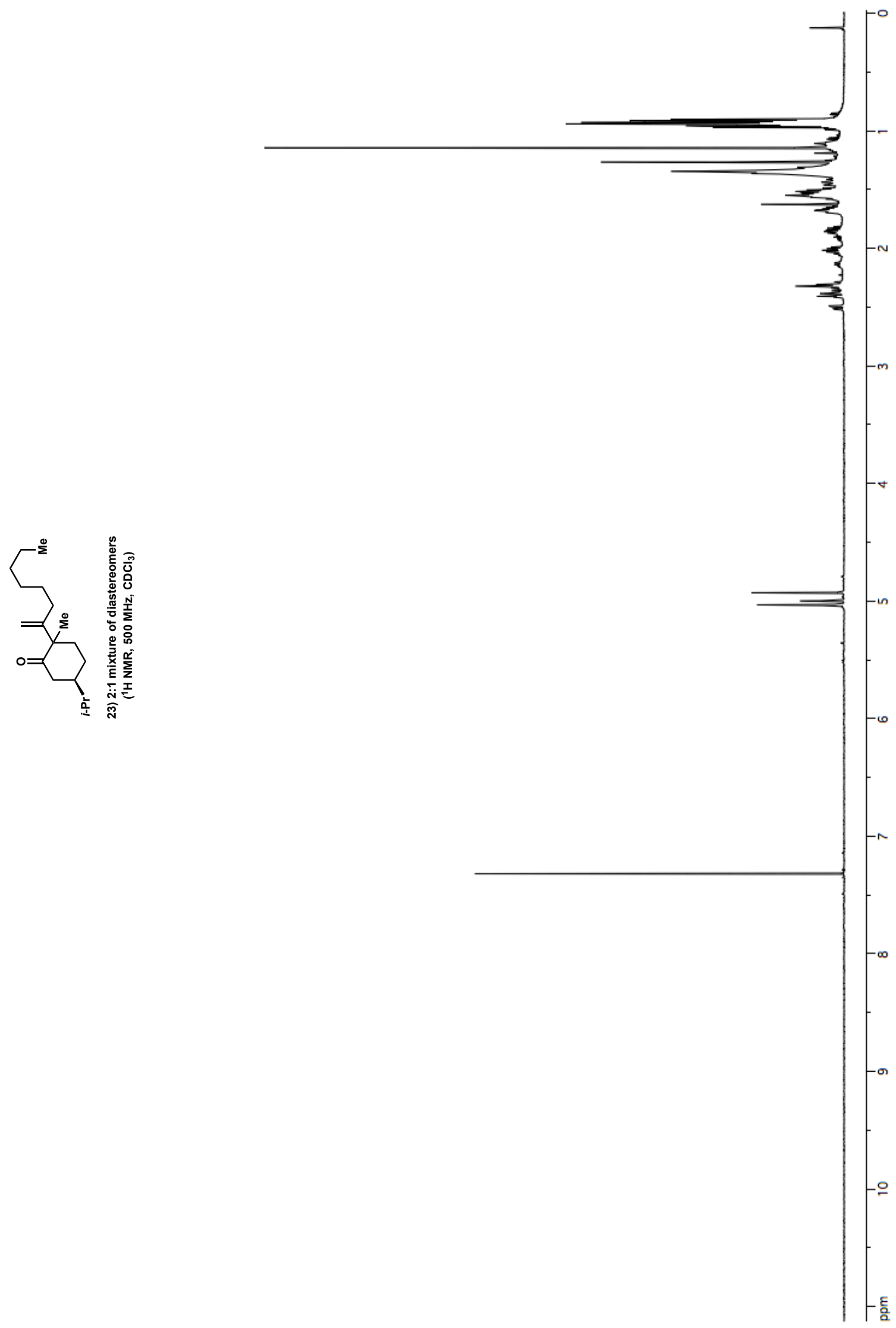

SI 103 


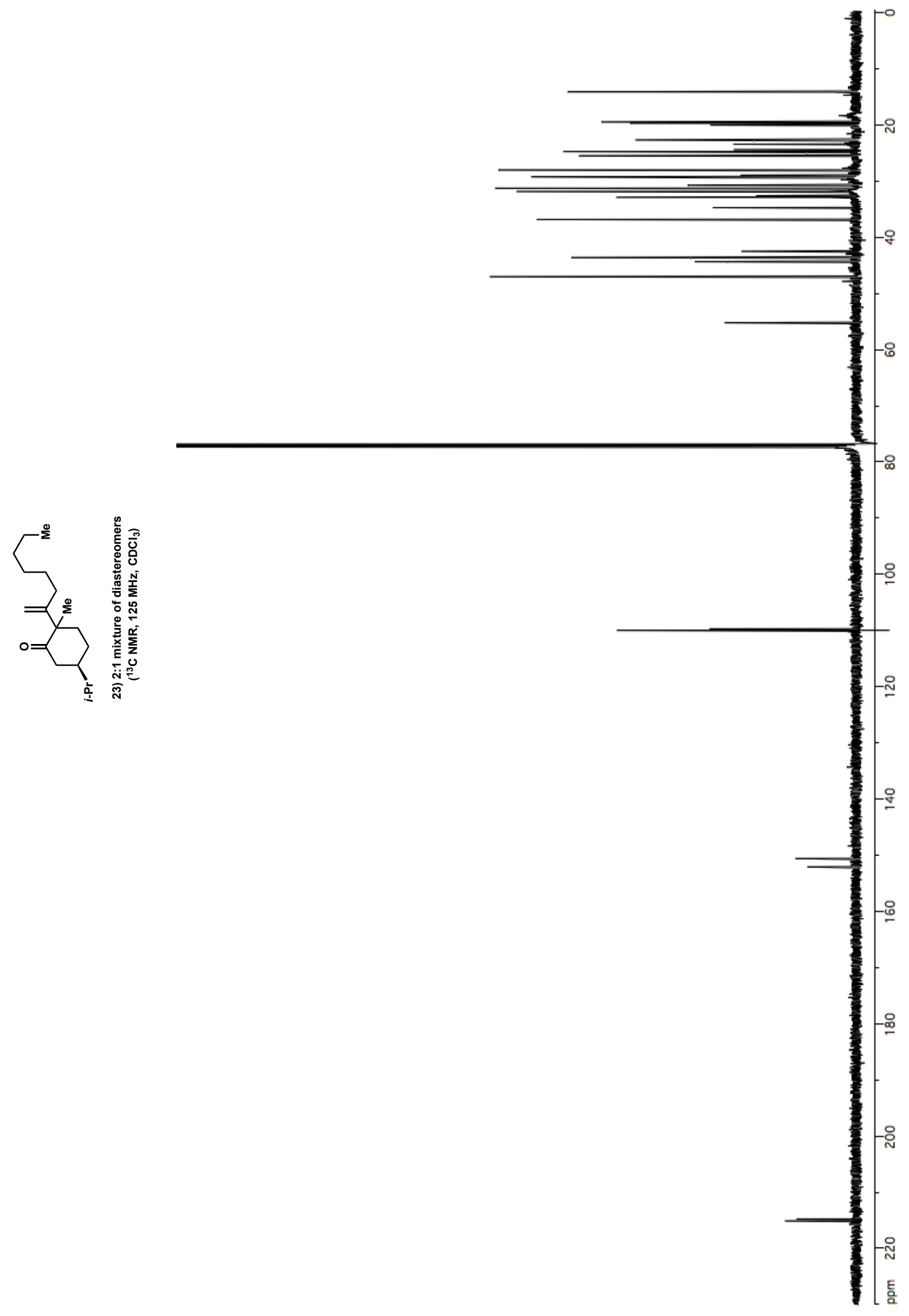

SI 104 


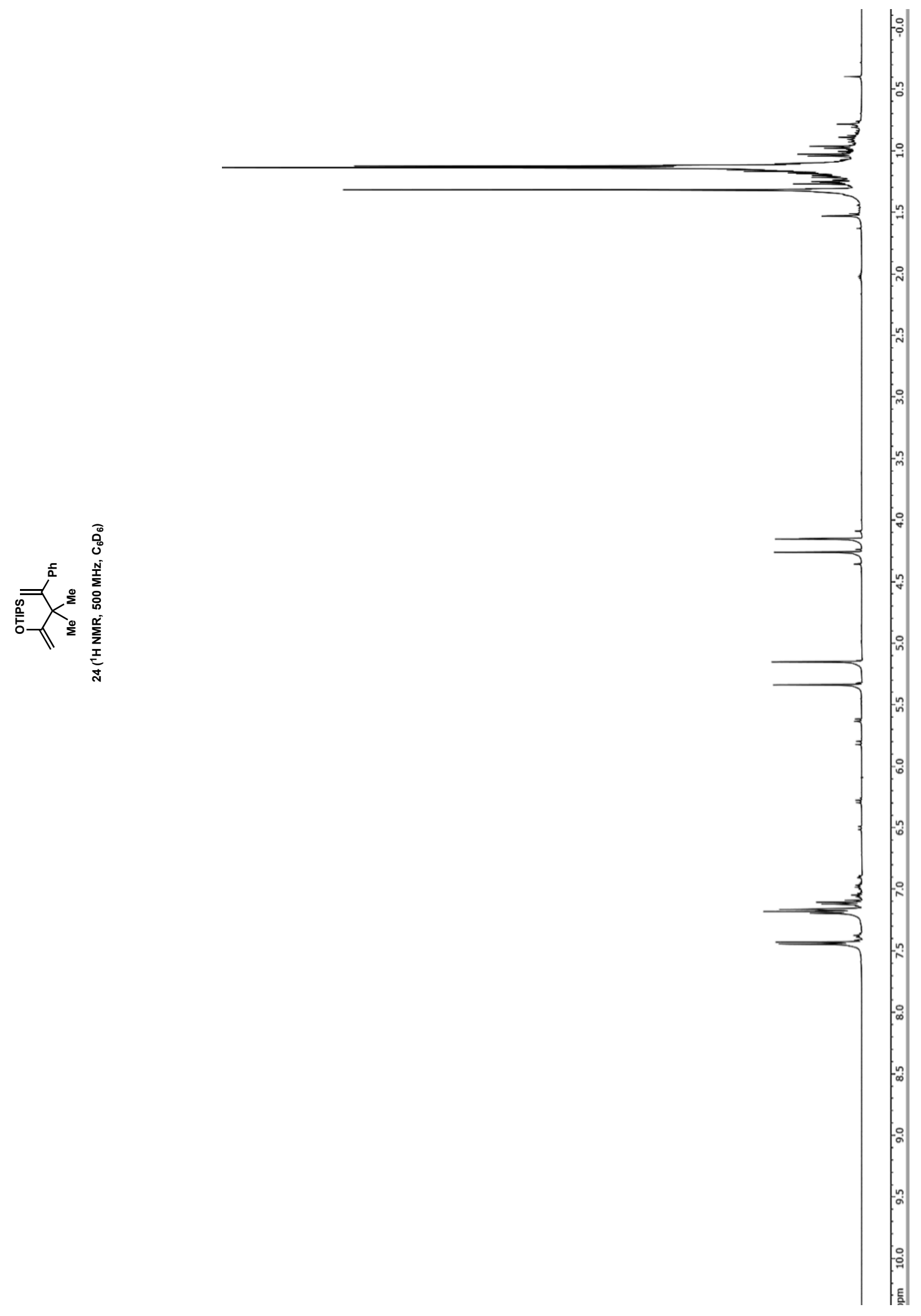




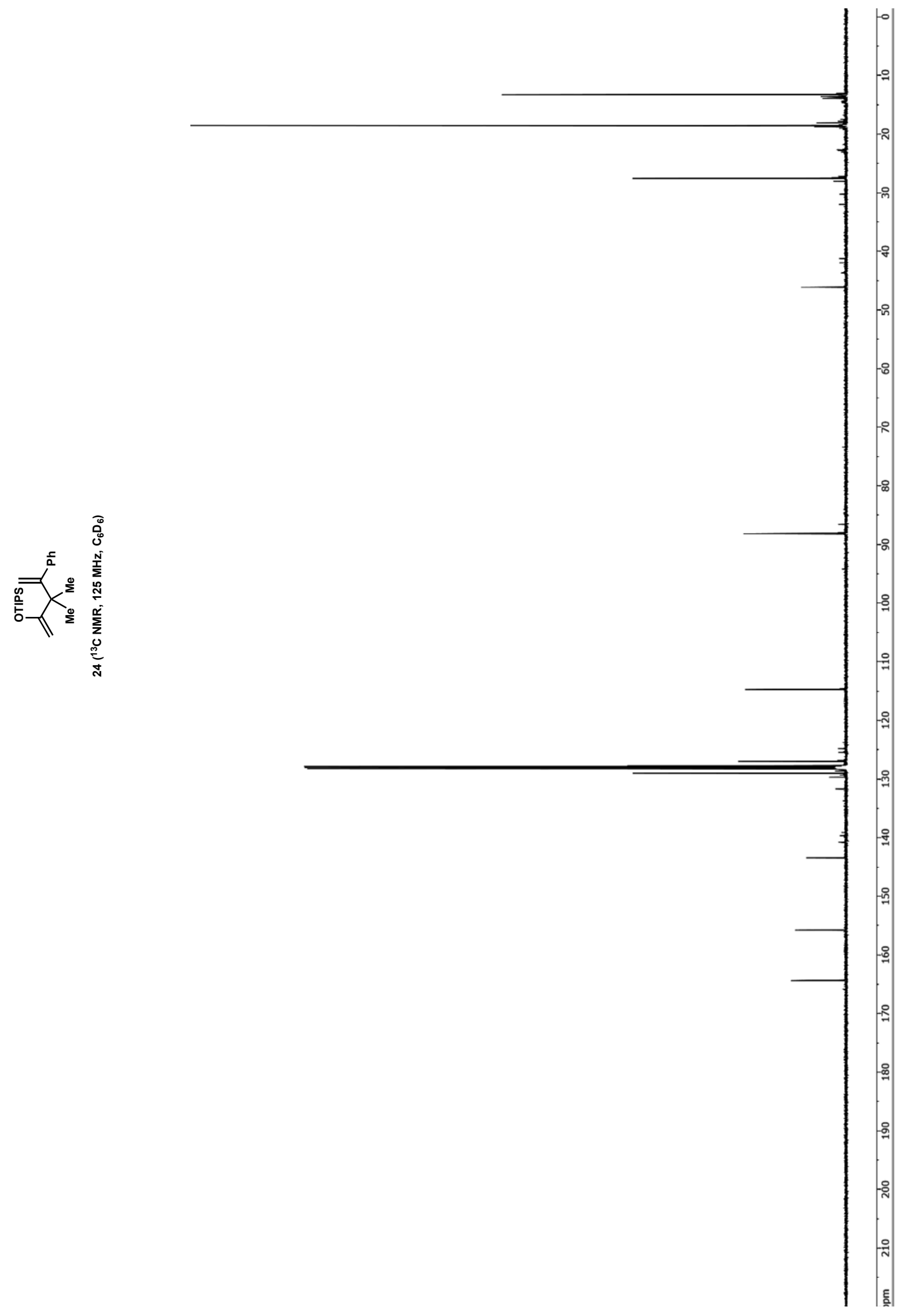




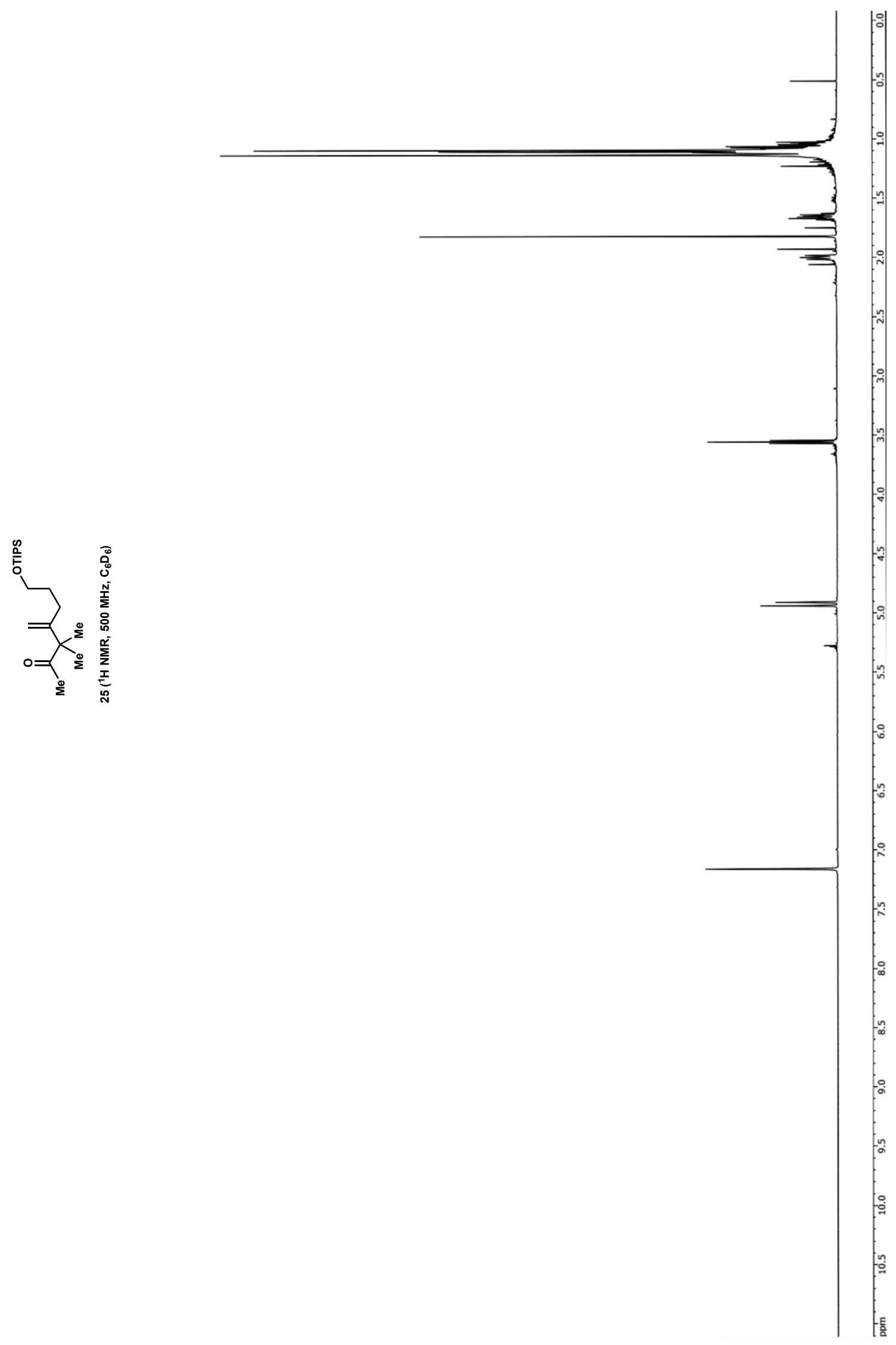




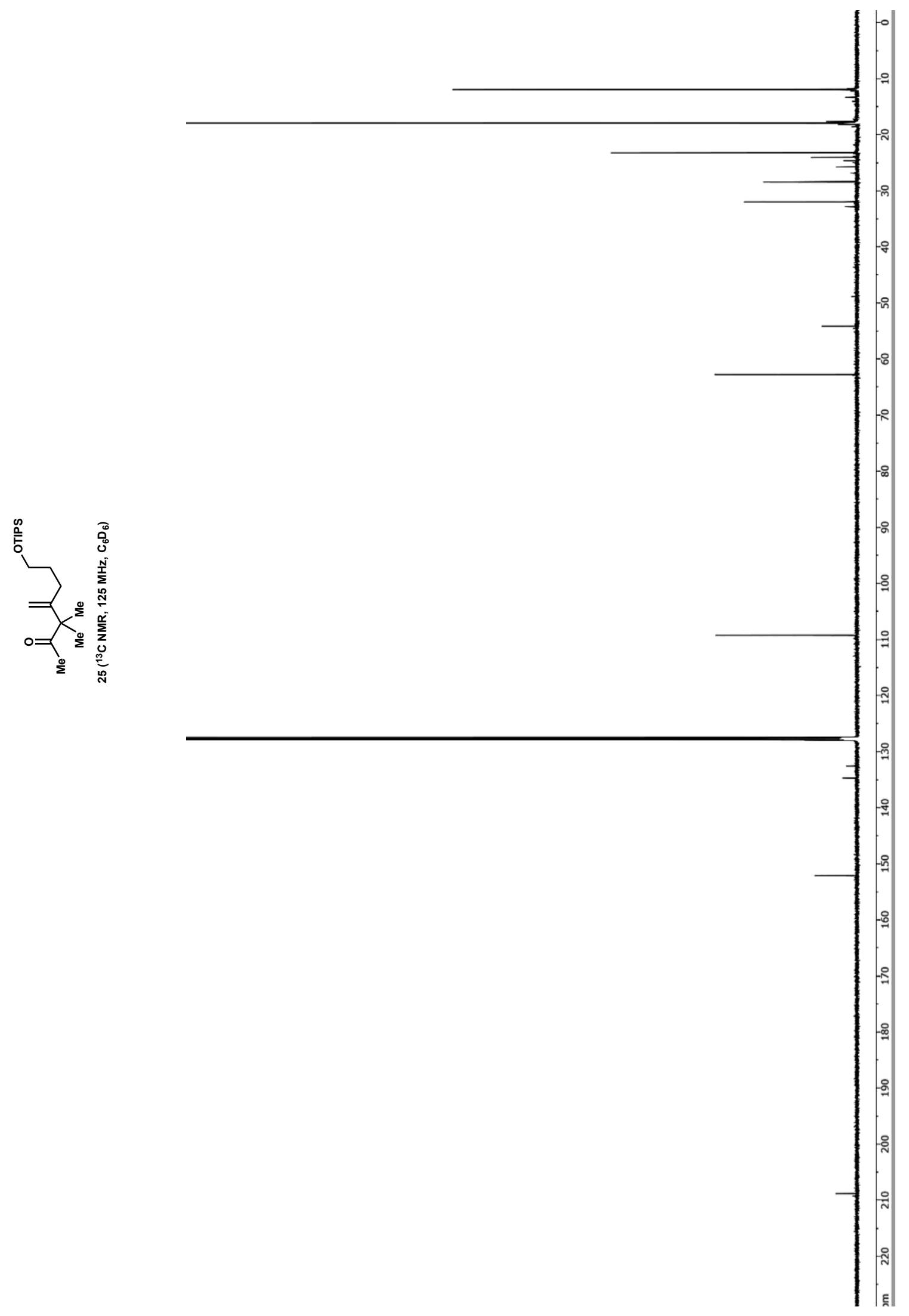




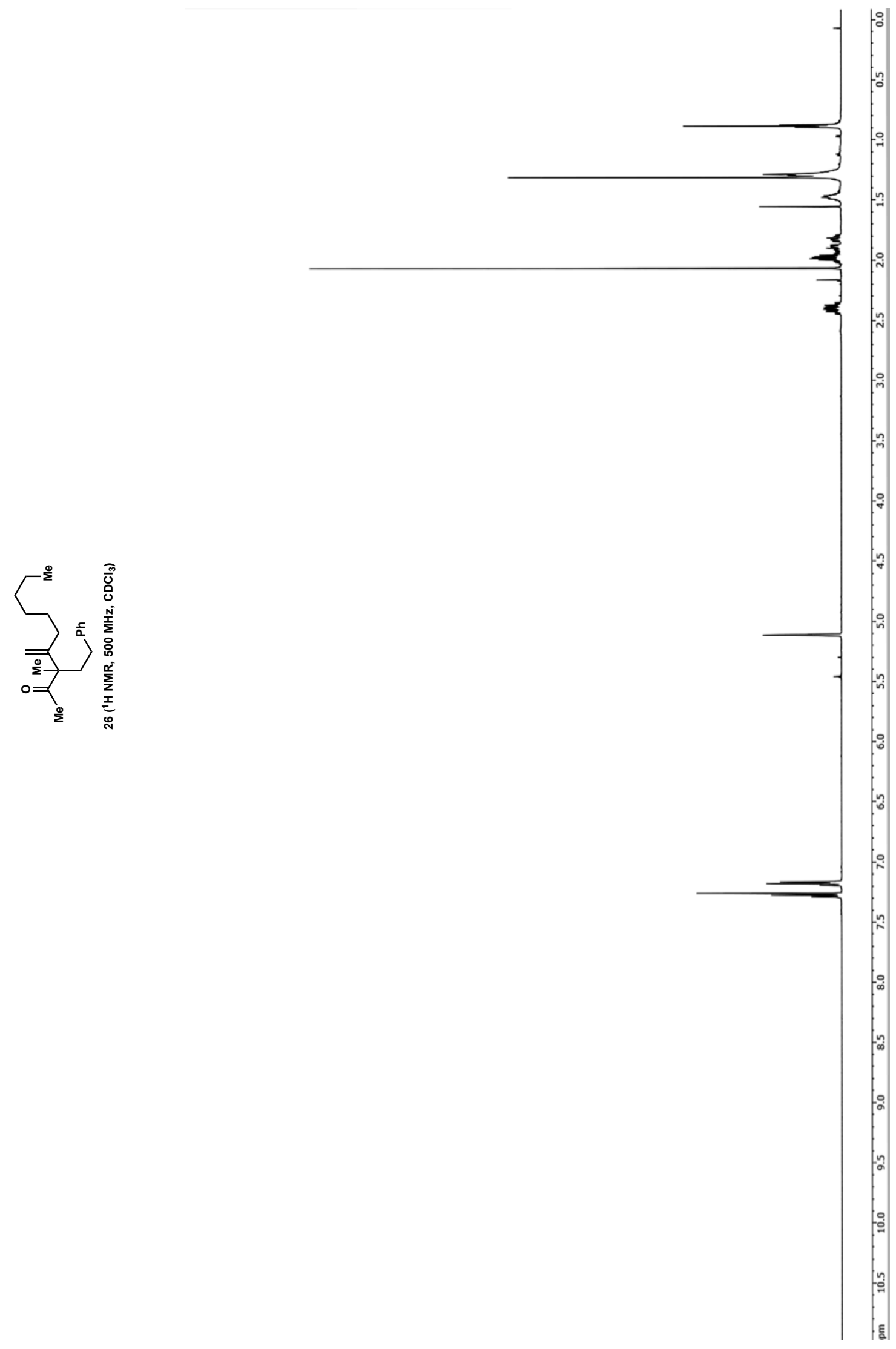




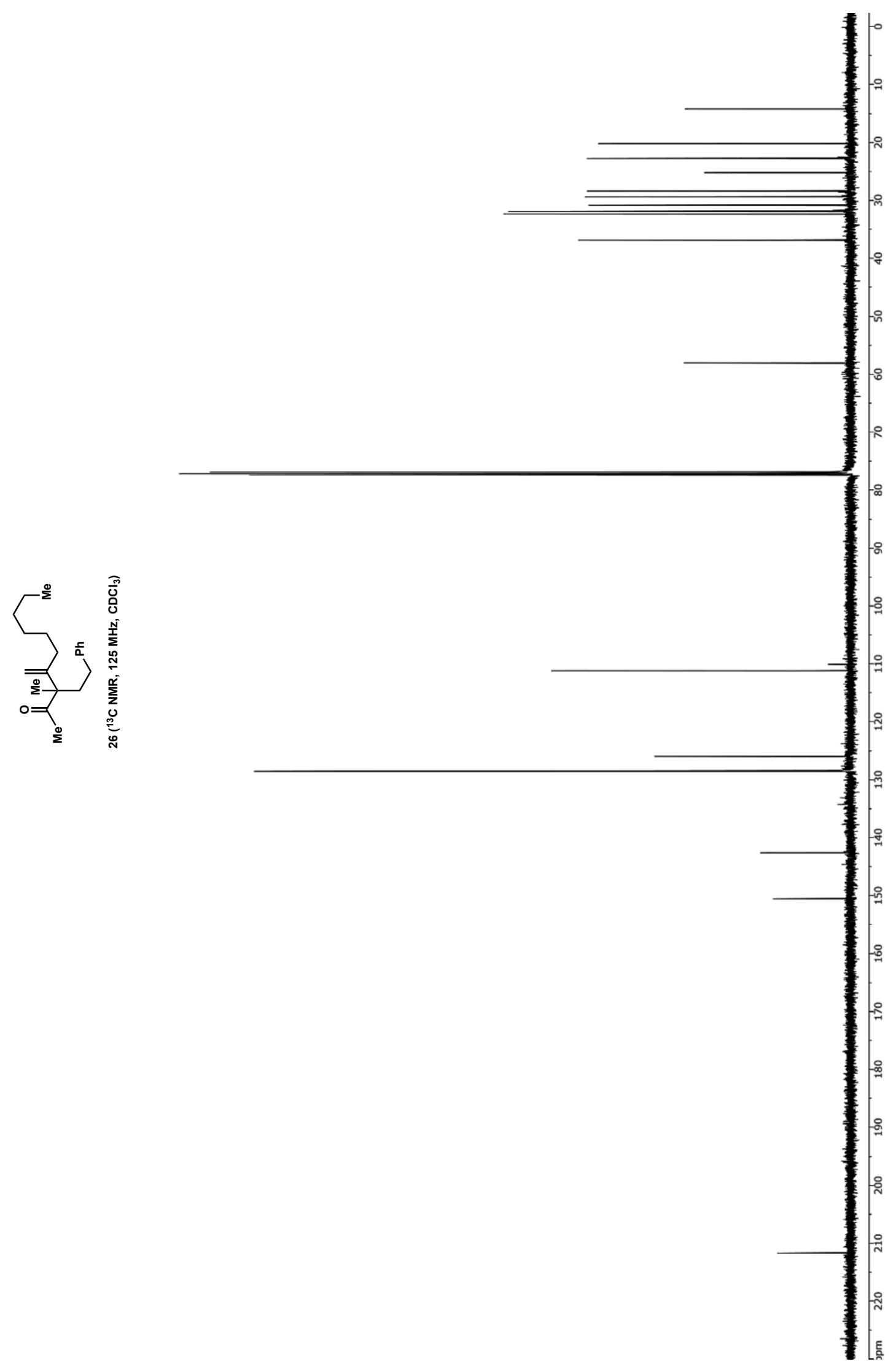

SI 110 


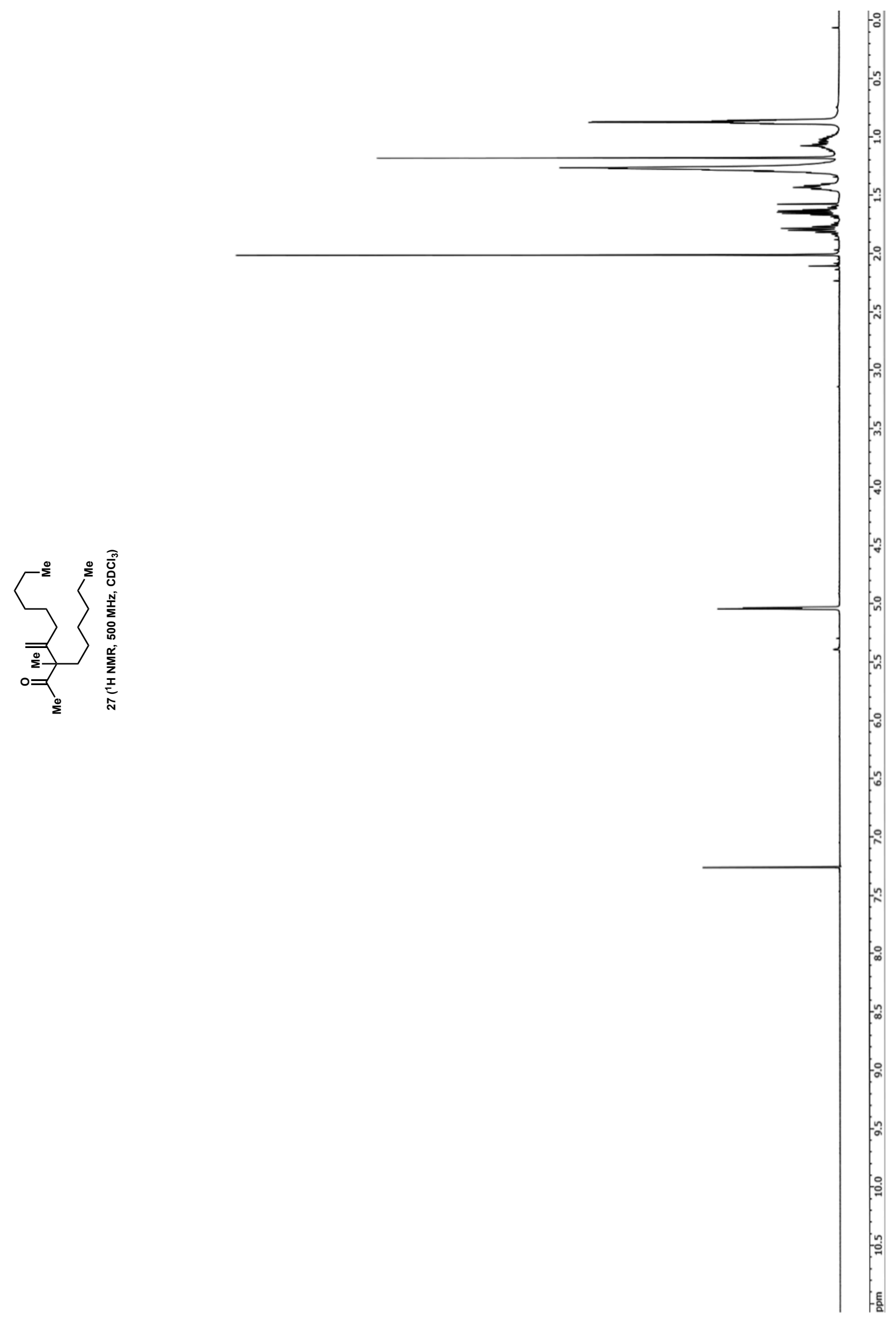




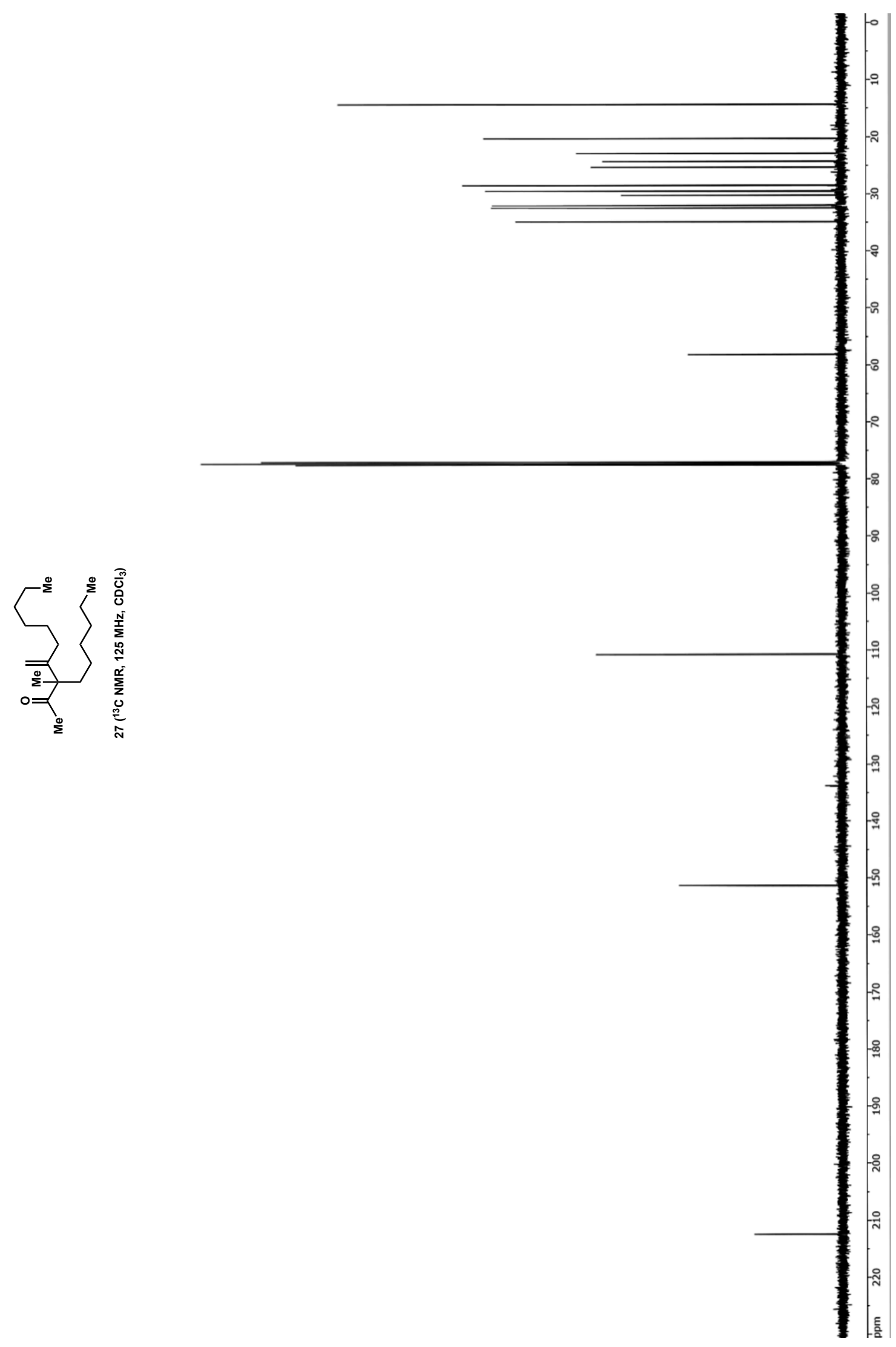

SI 112 


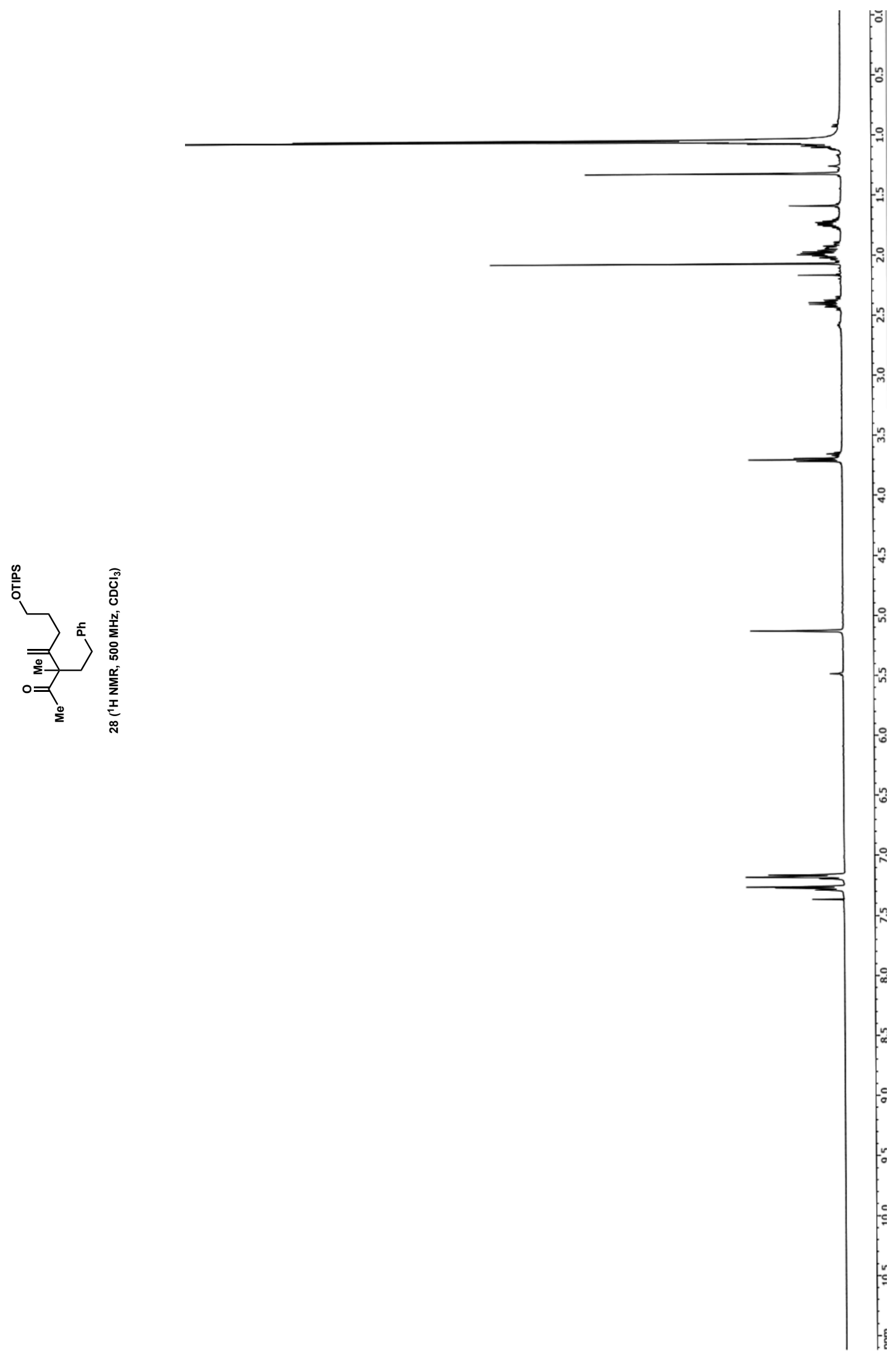

SI 113 


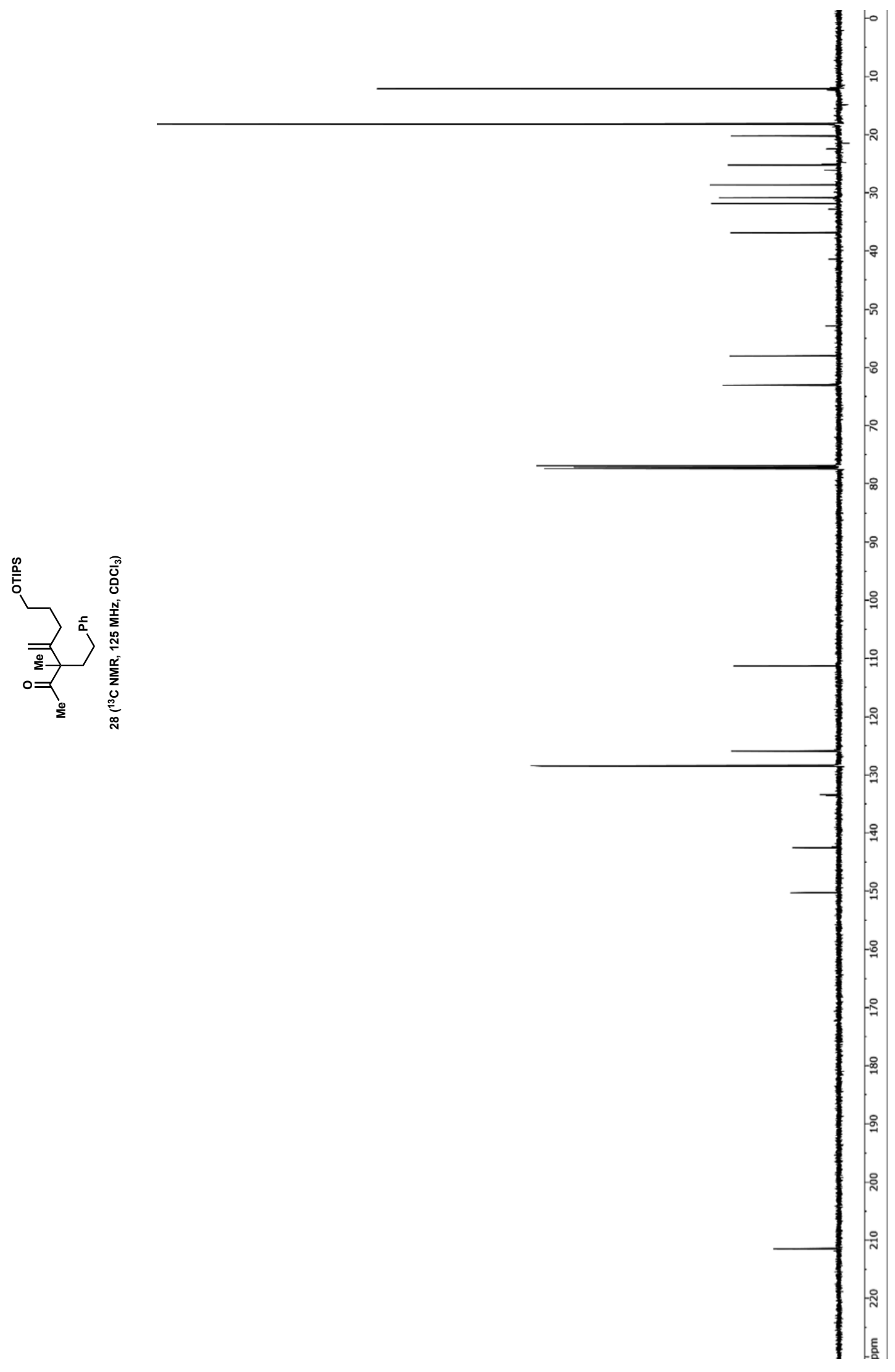




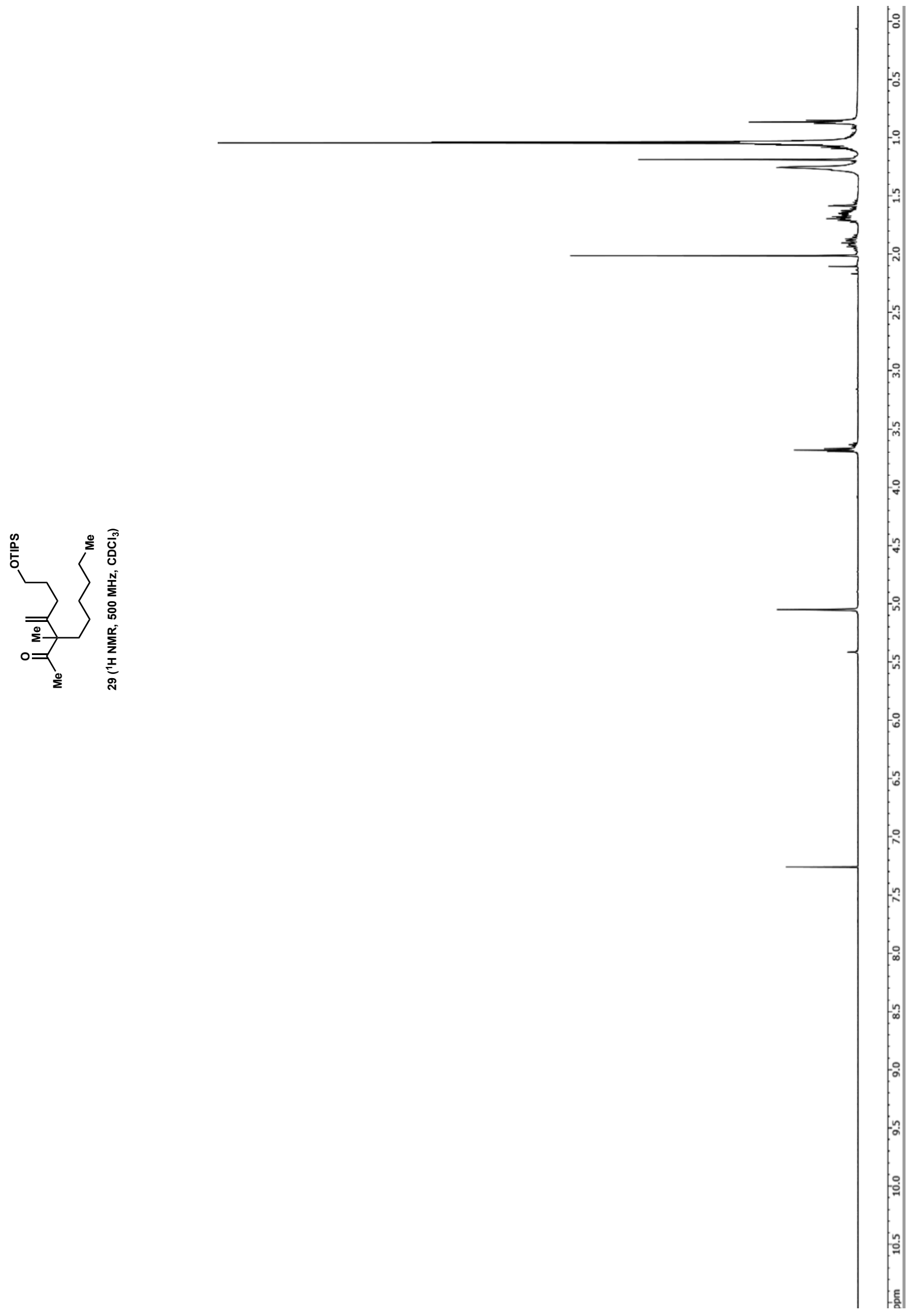




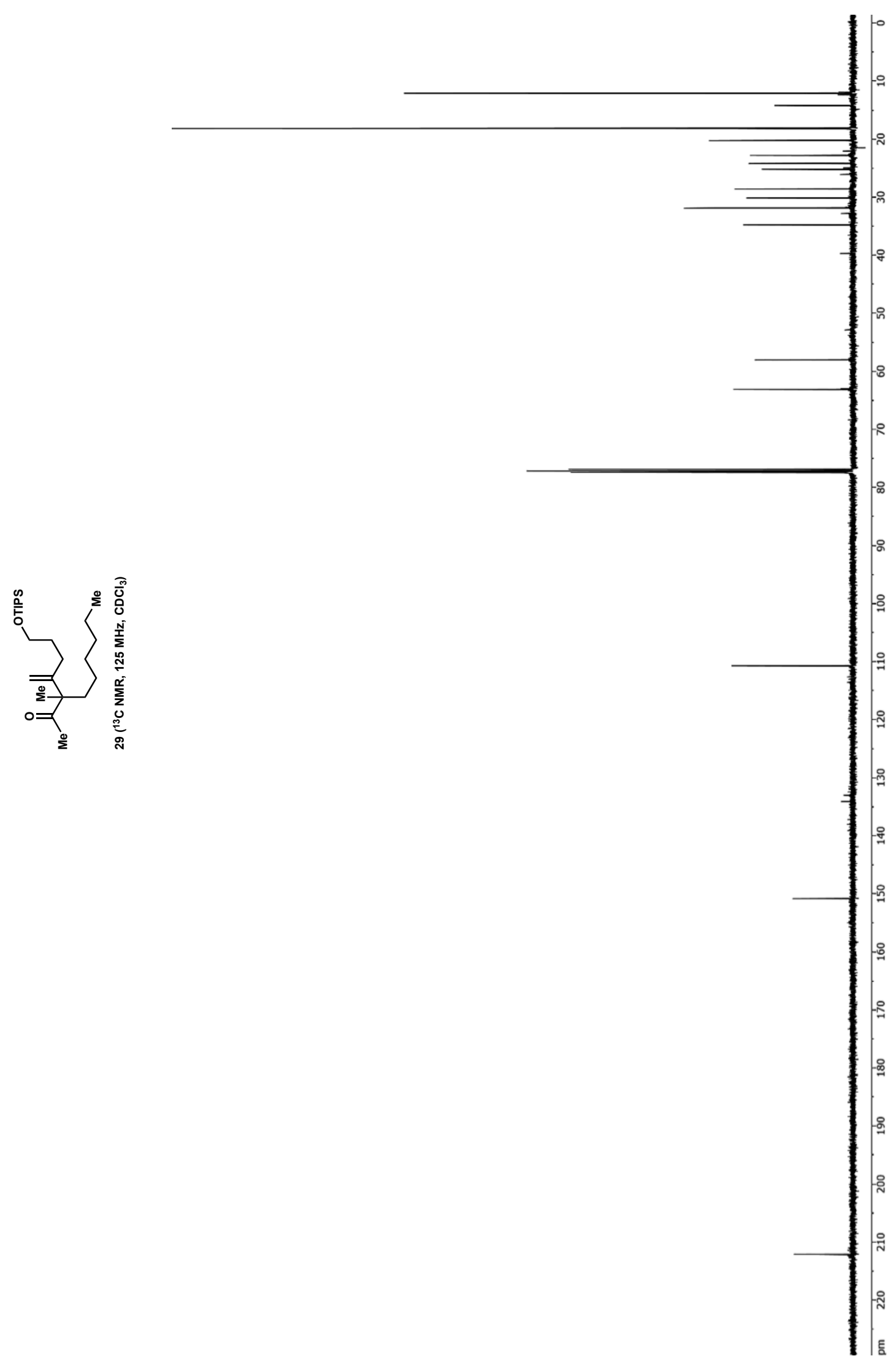

SI 116 


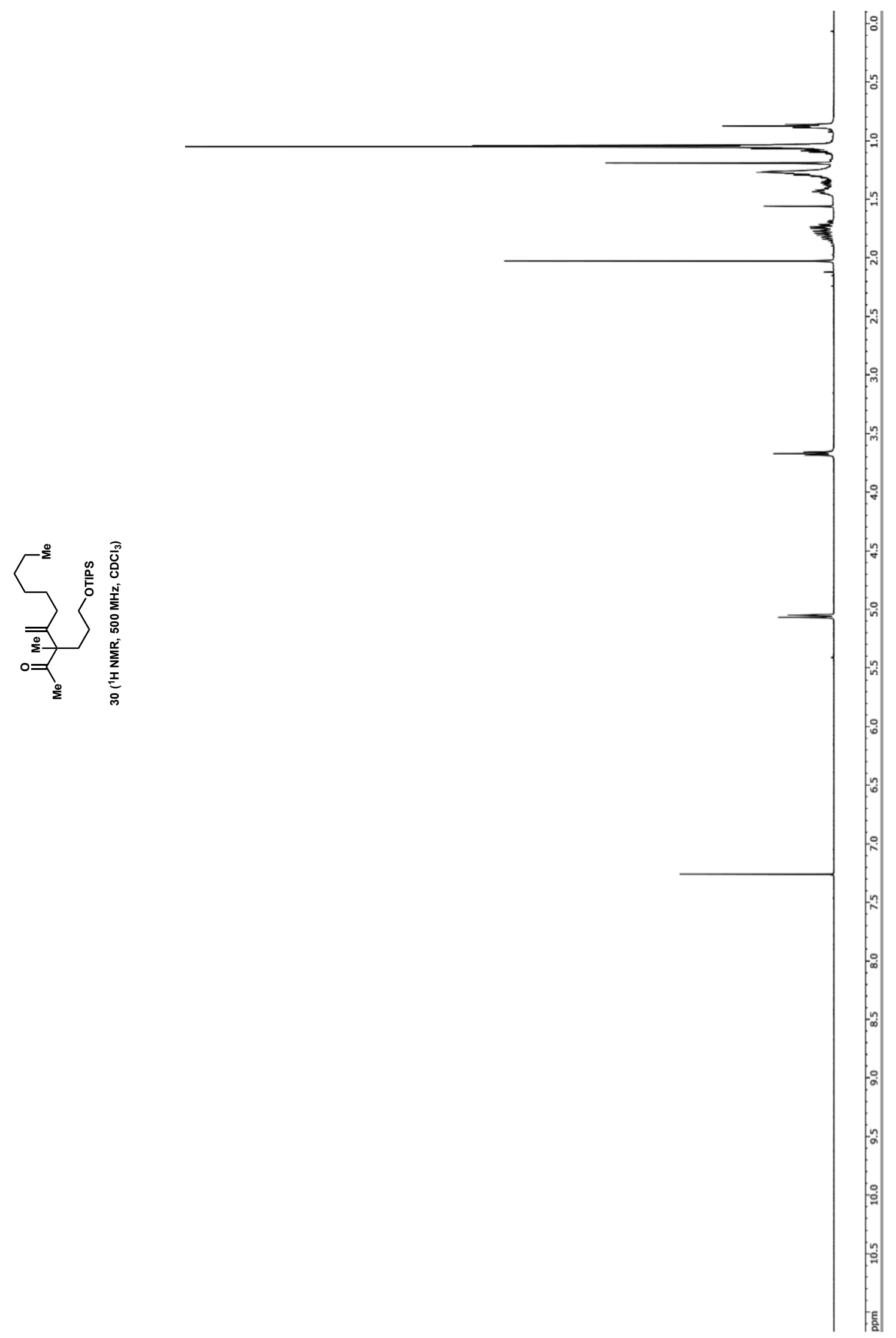




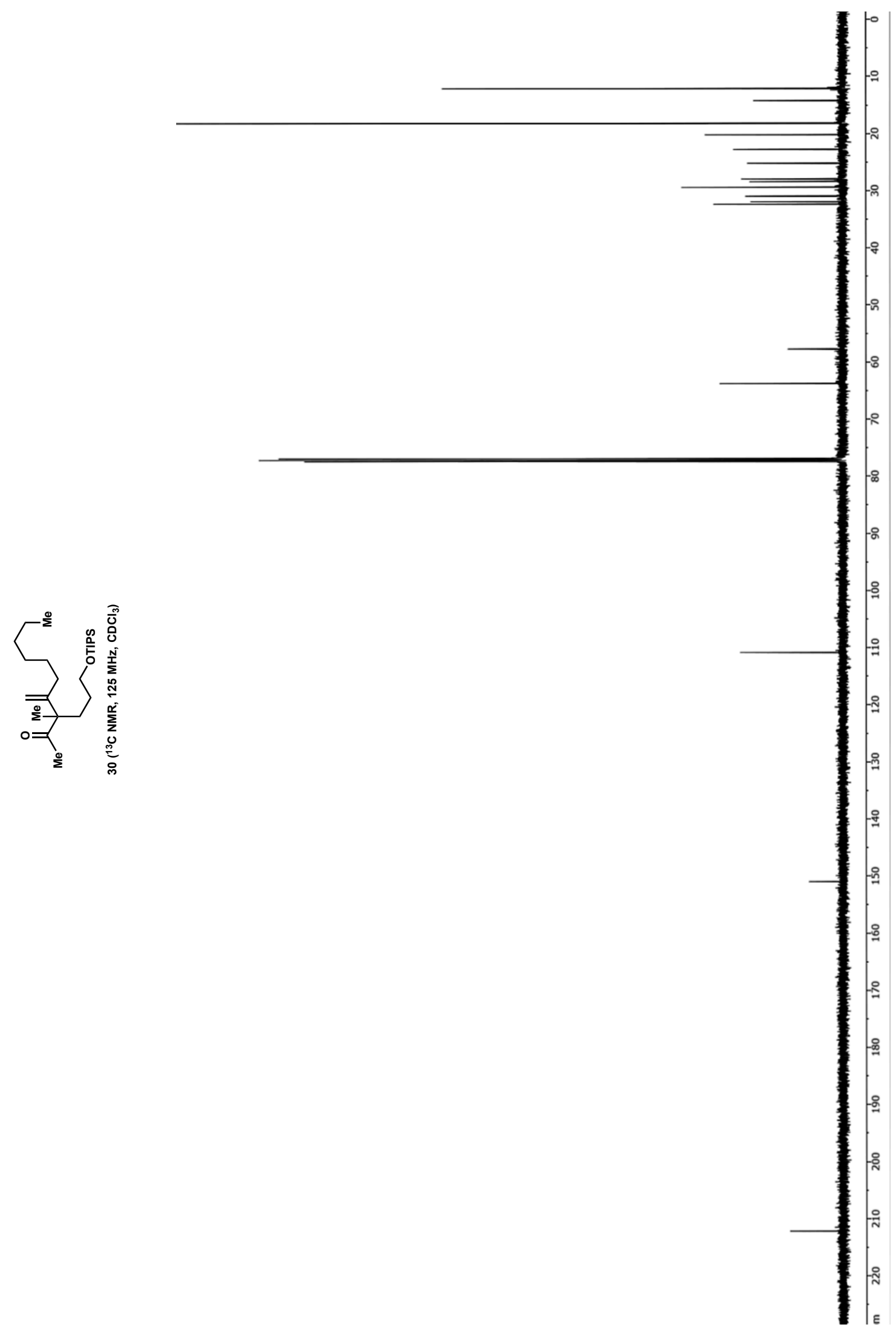

SI 118 


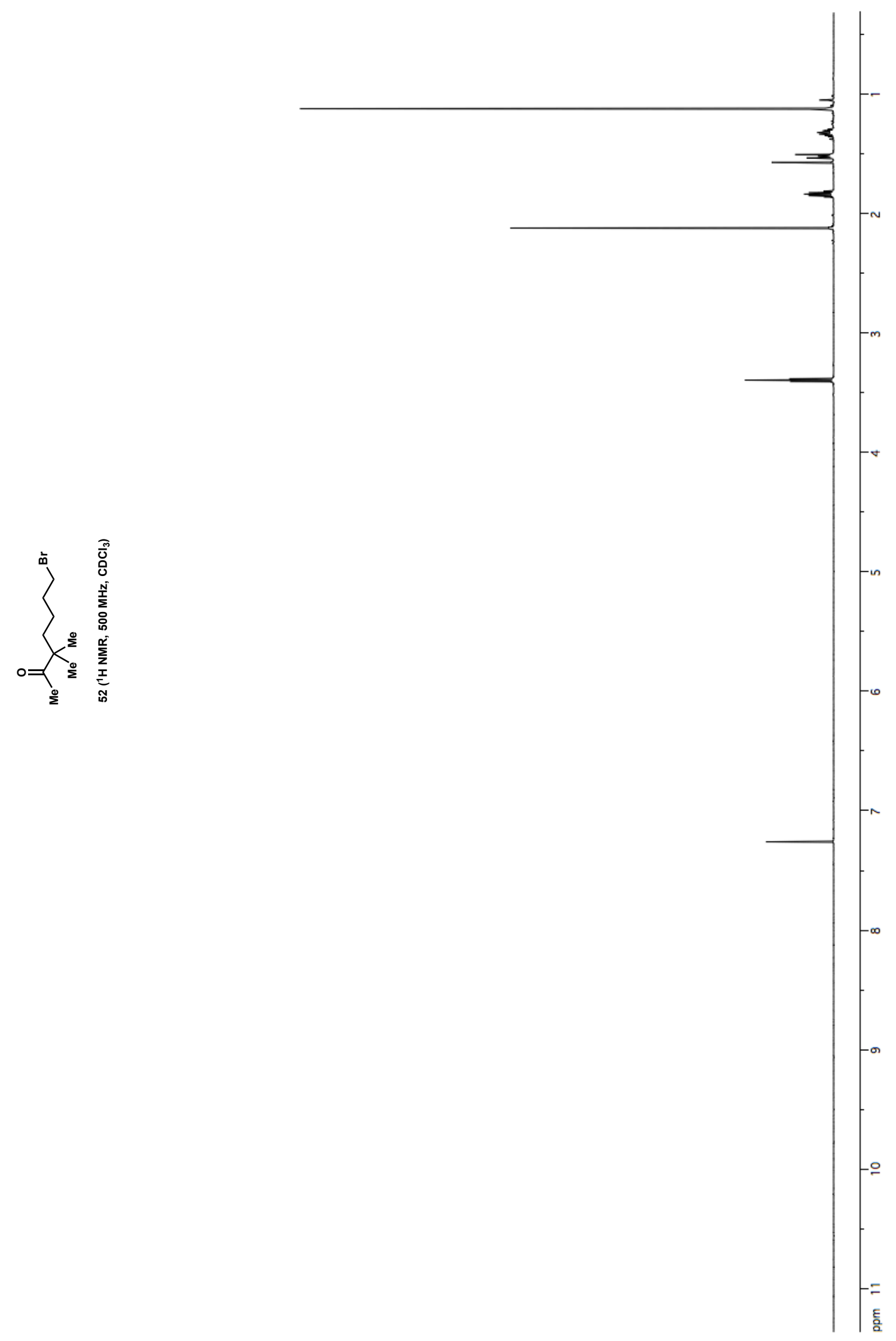

SI 119 


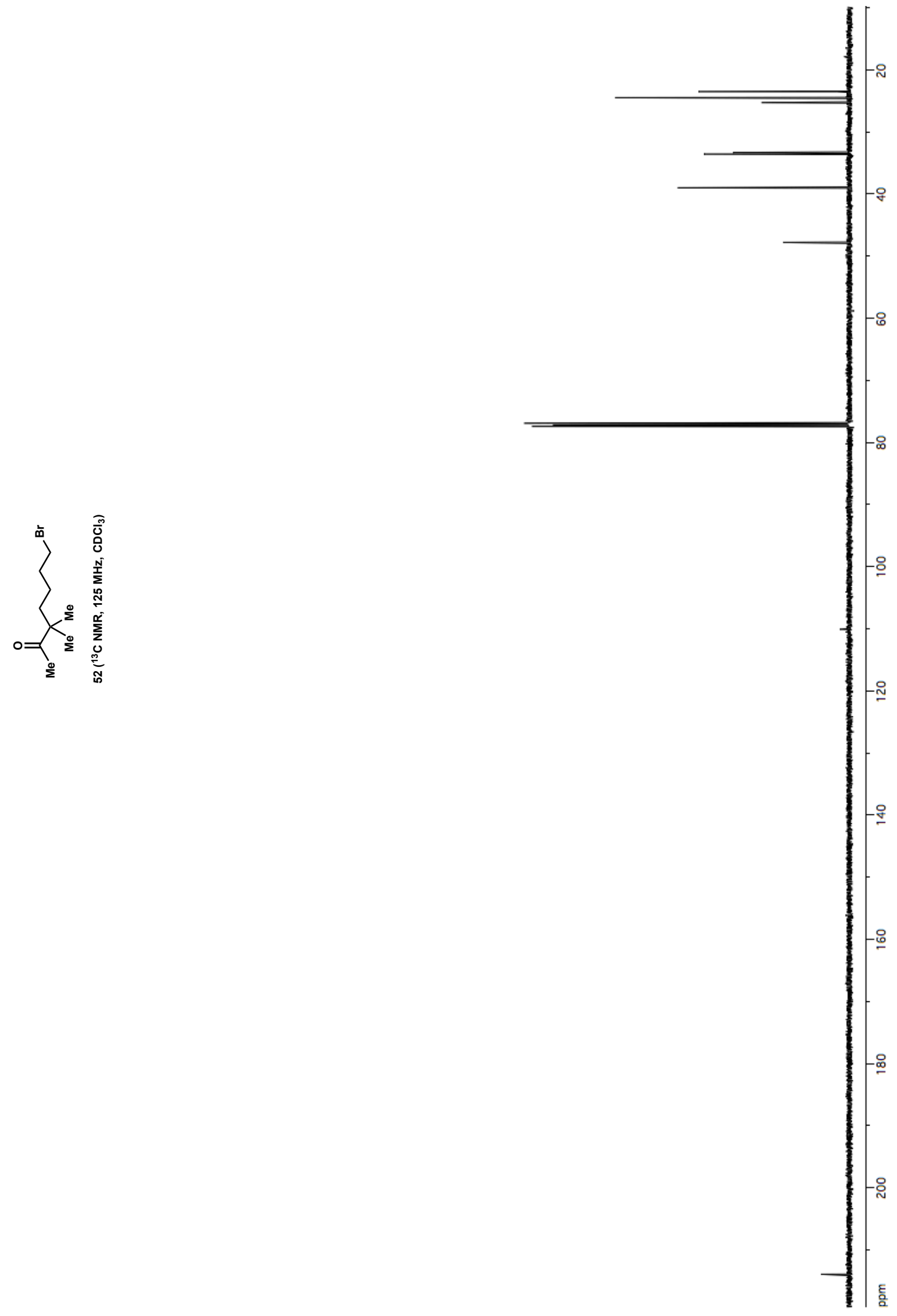

SI 120 


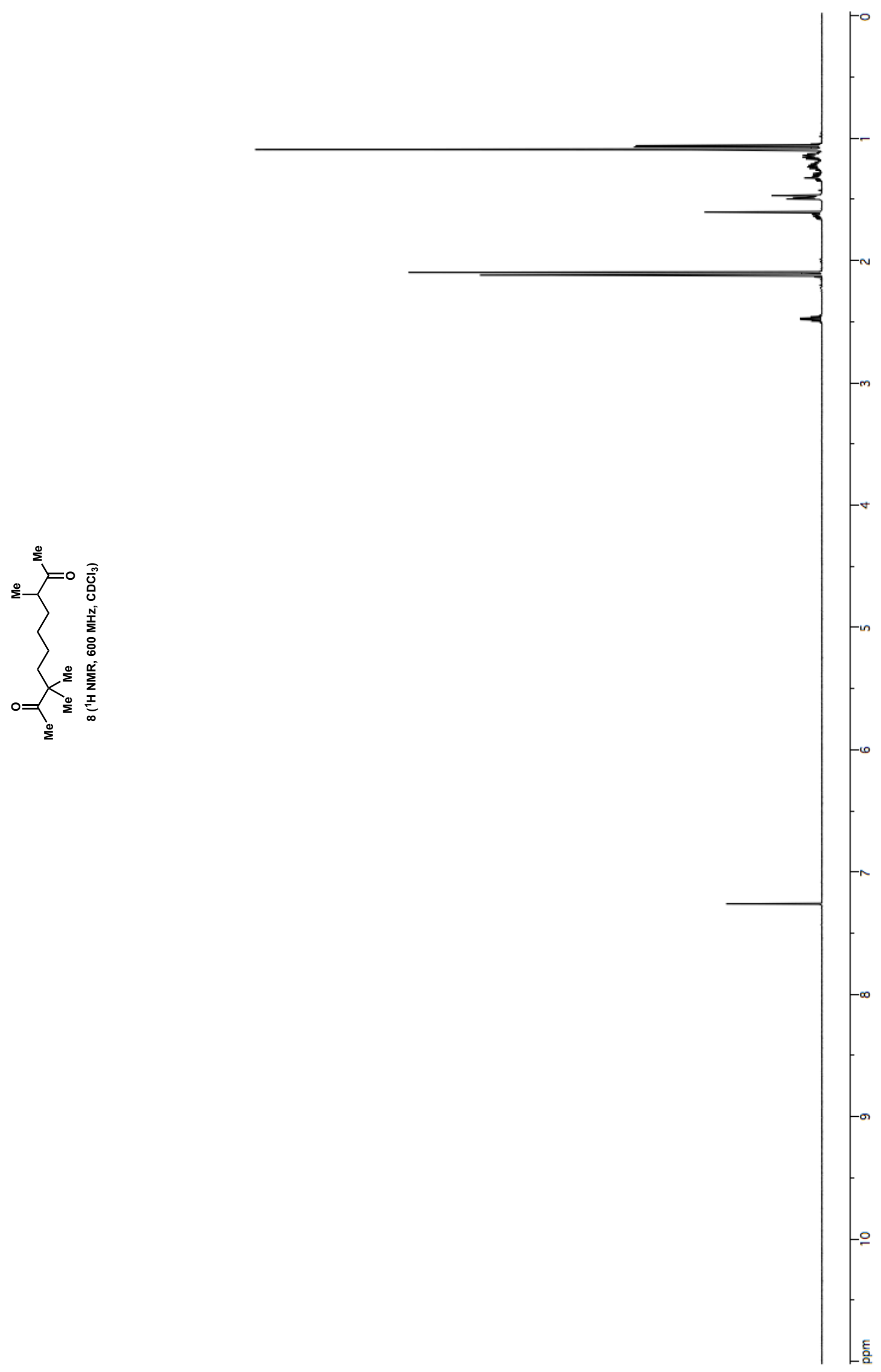




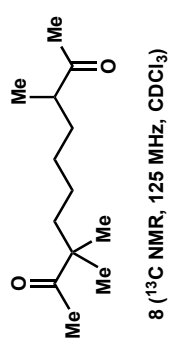

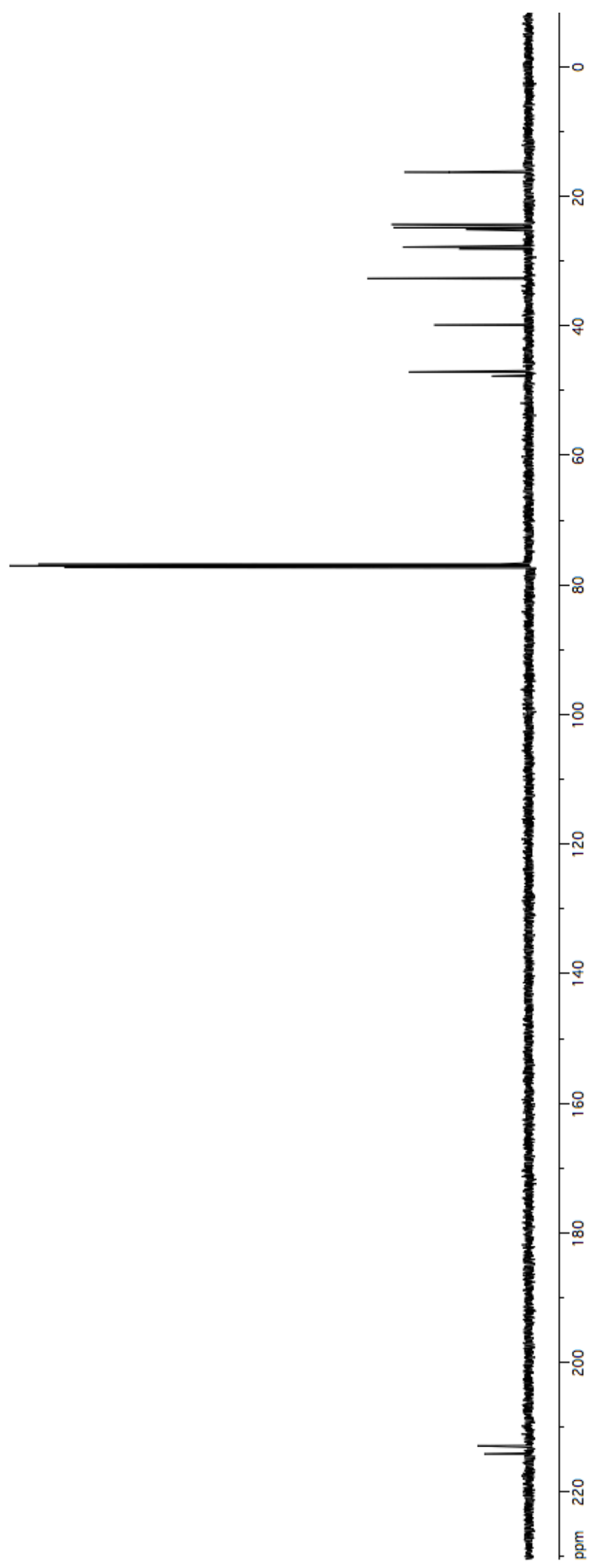

SI 122 


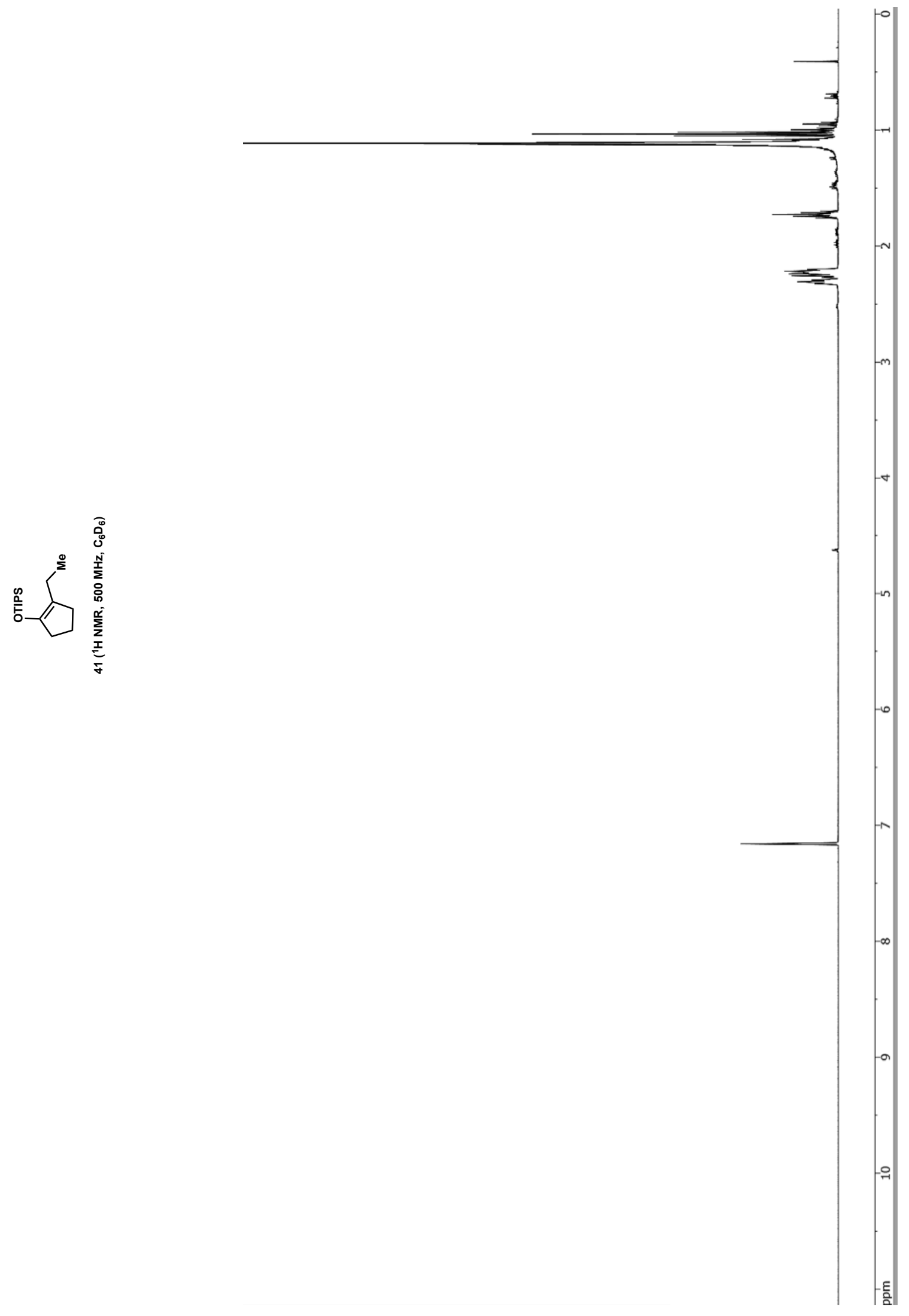

SI 123 


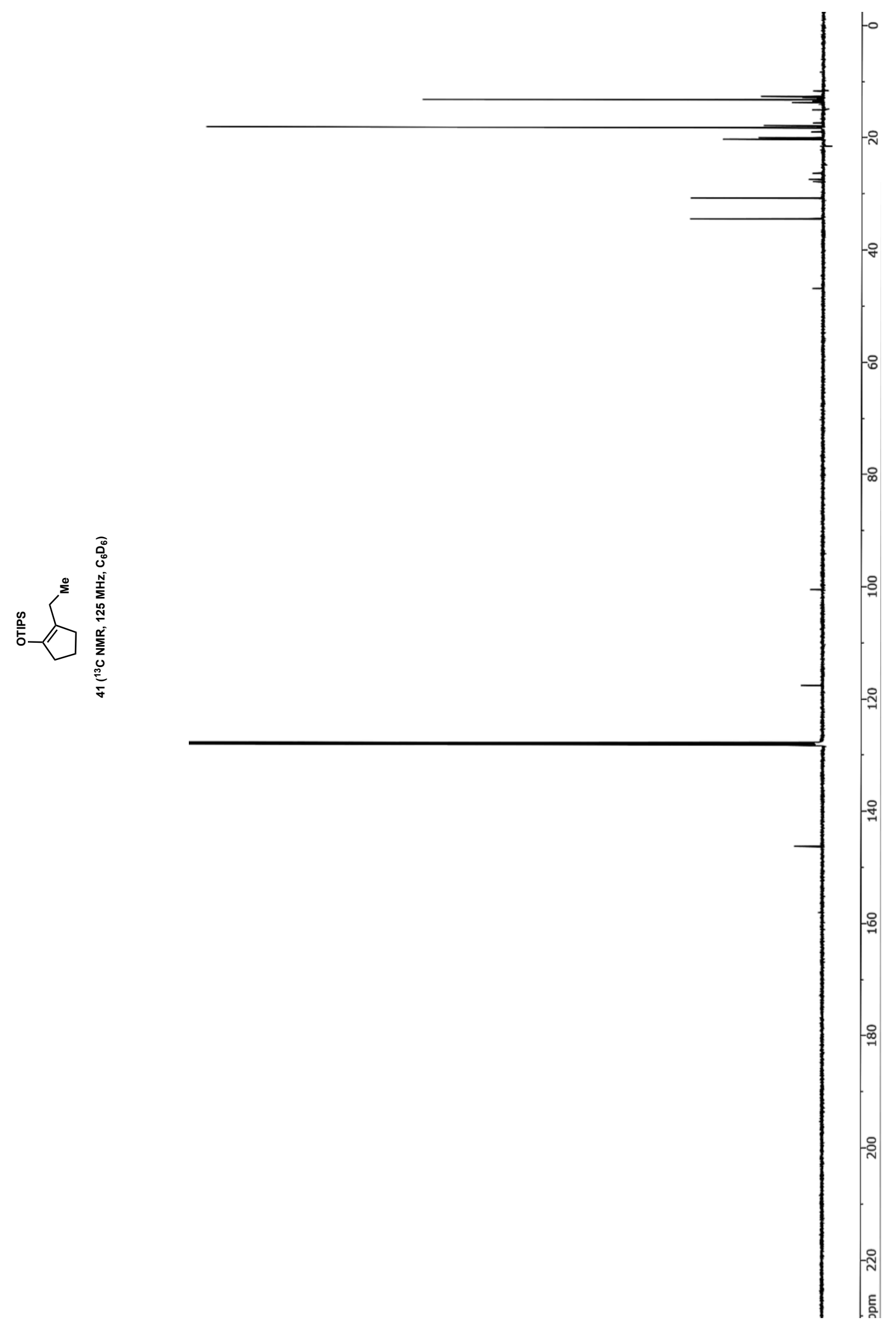

SI 124 


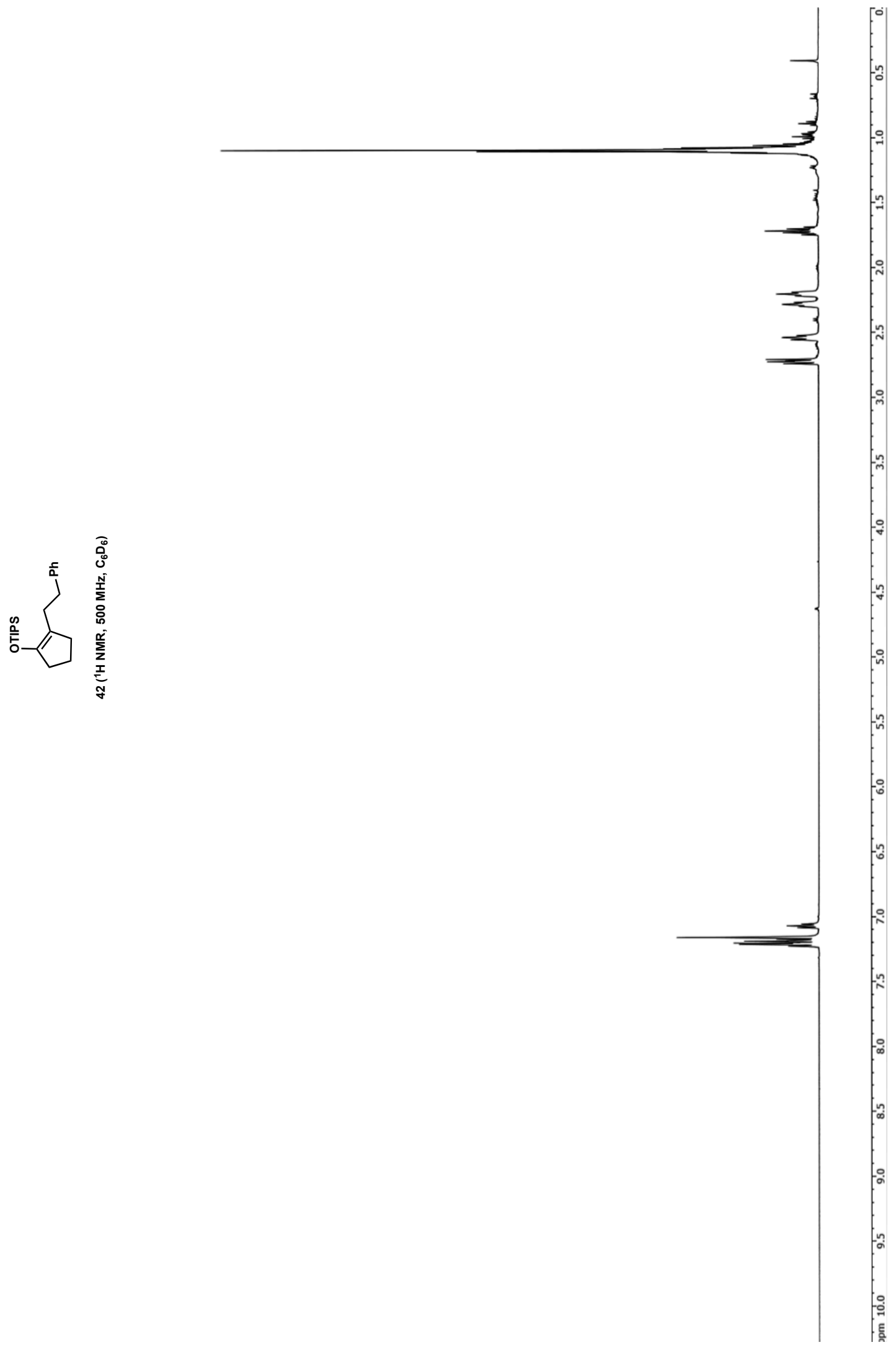




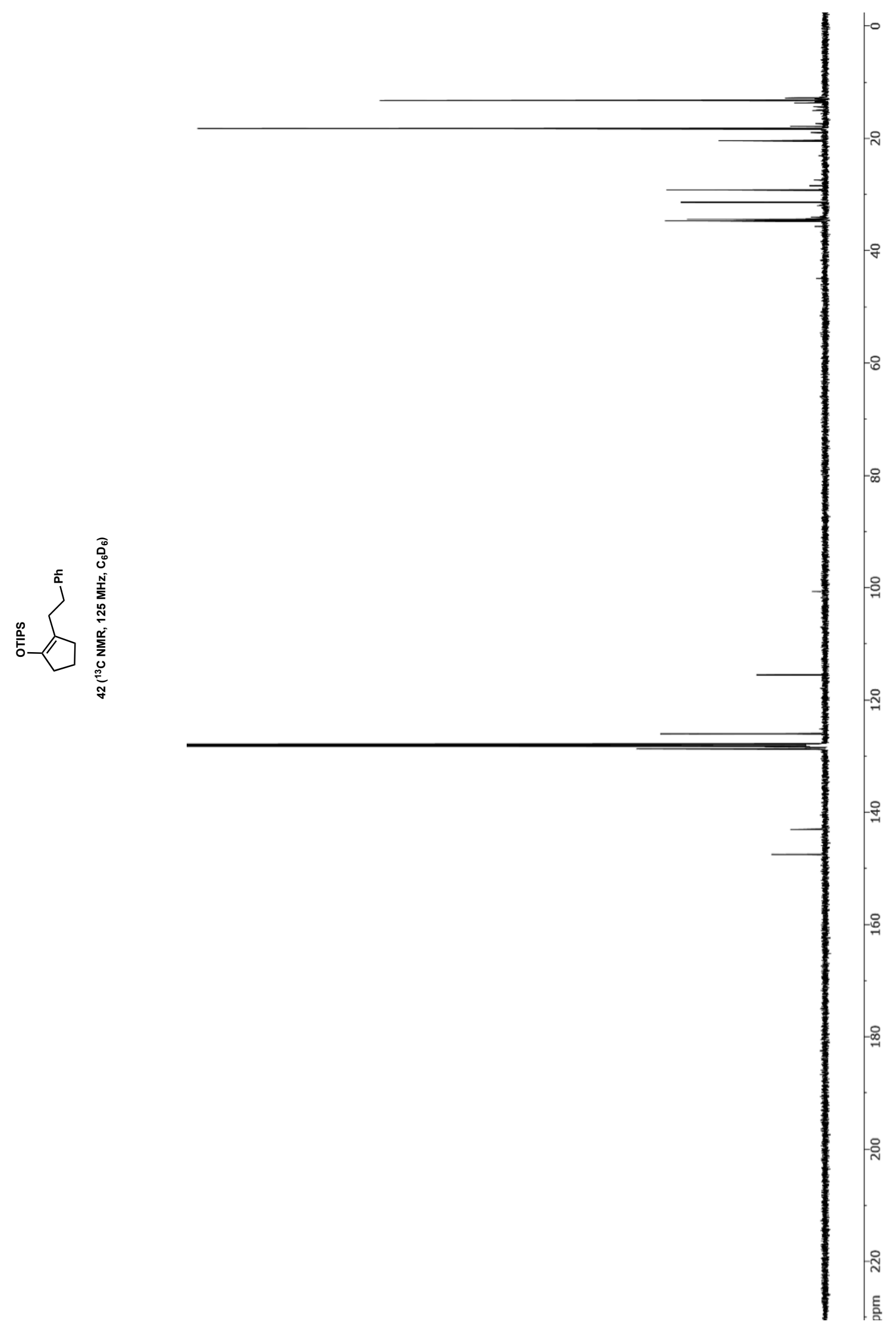

SI 126 


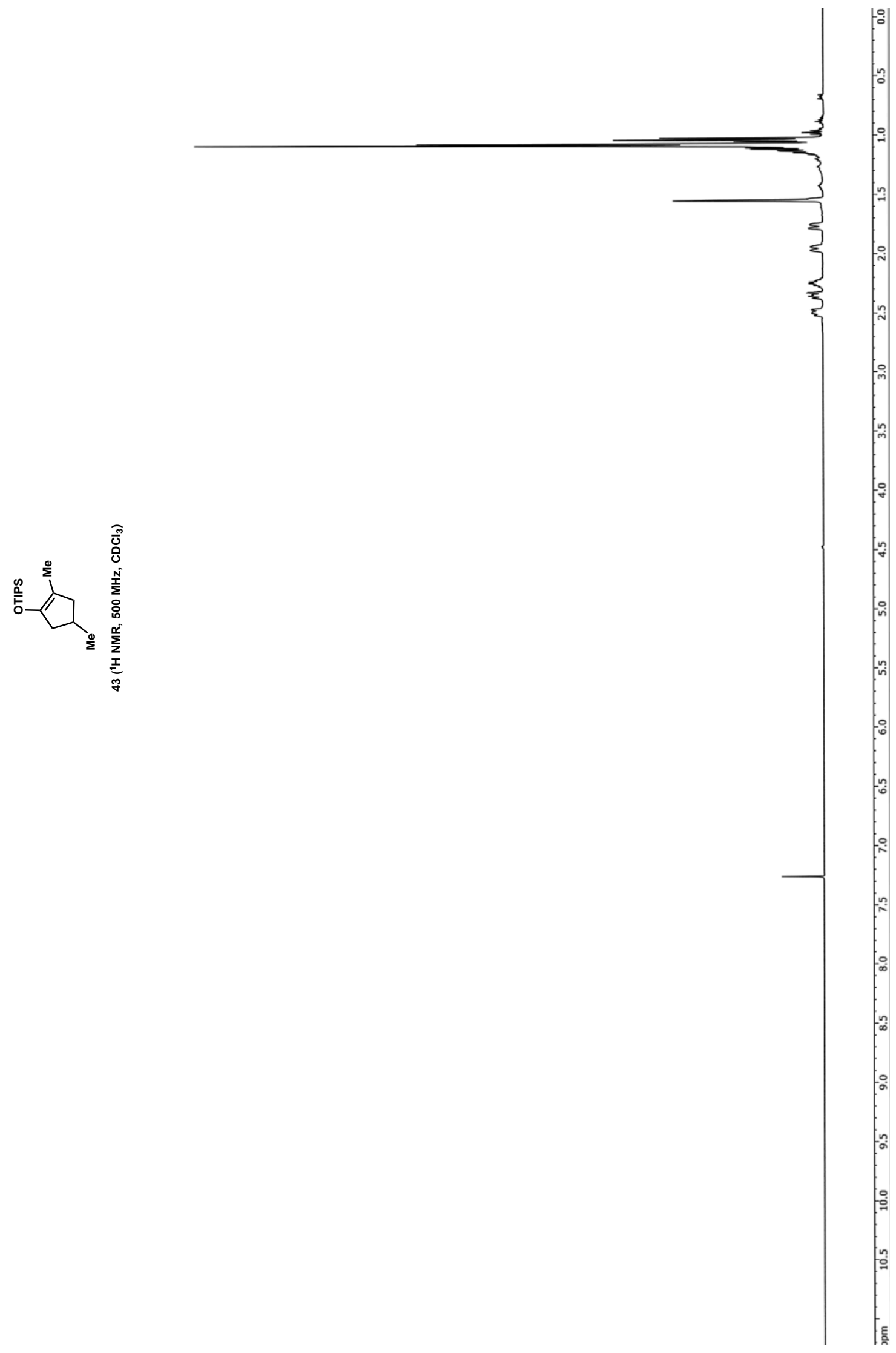




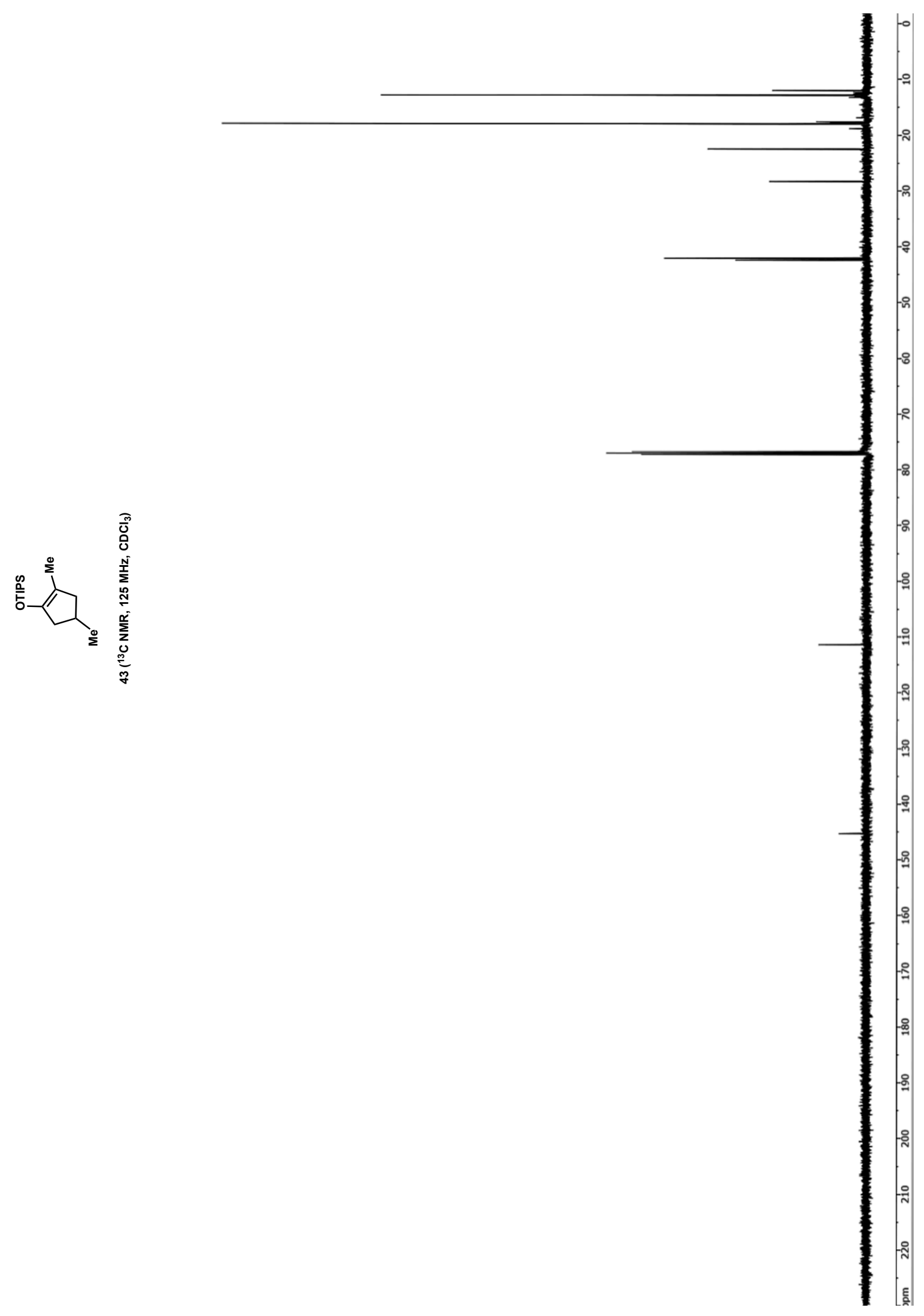

SI 128 


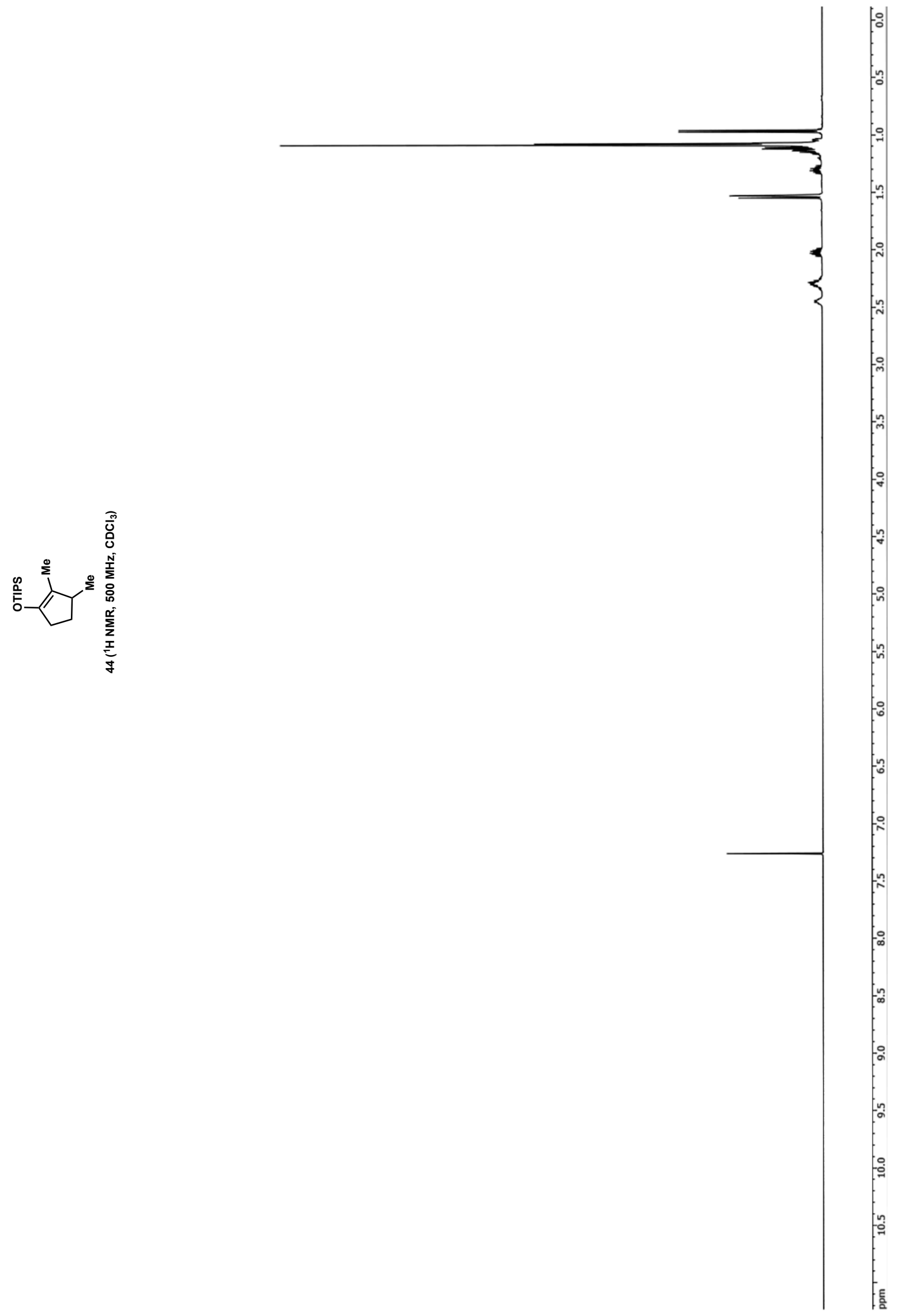




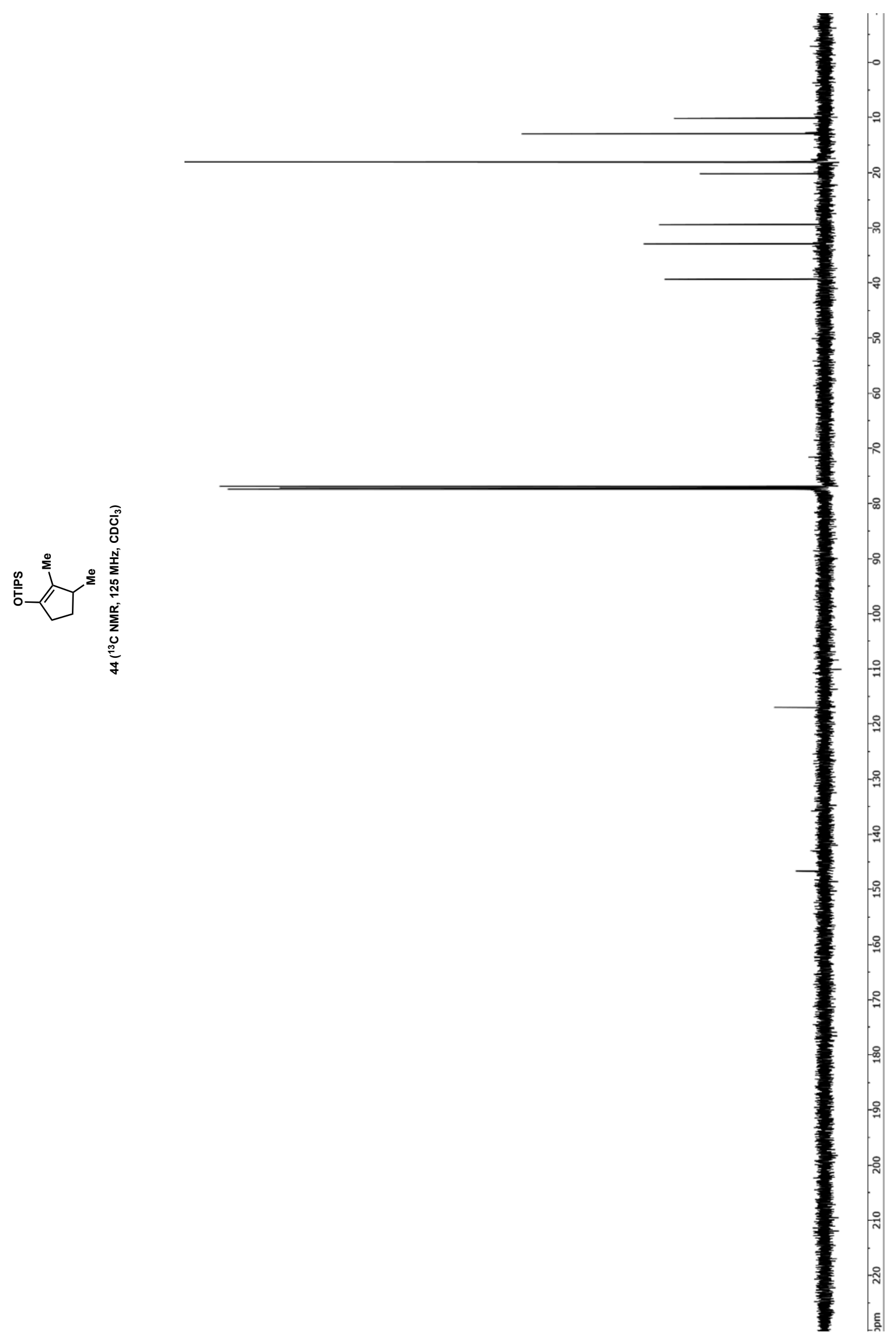




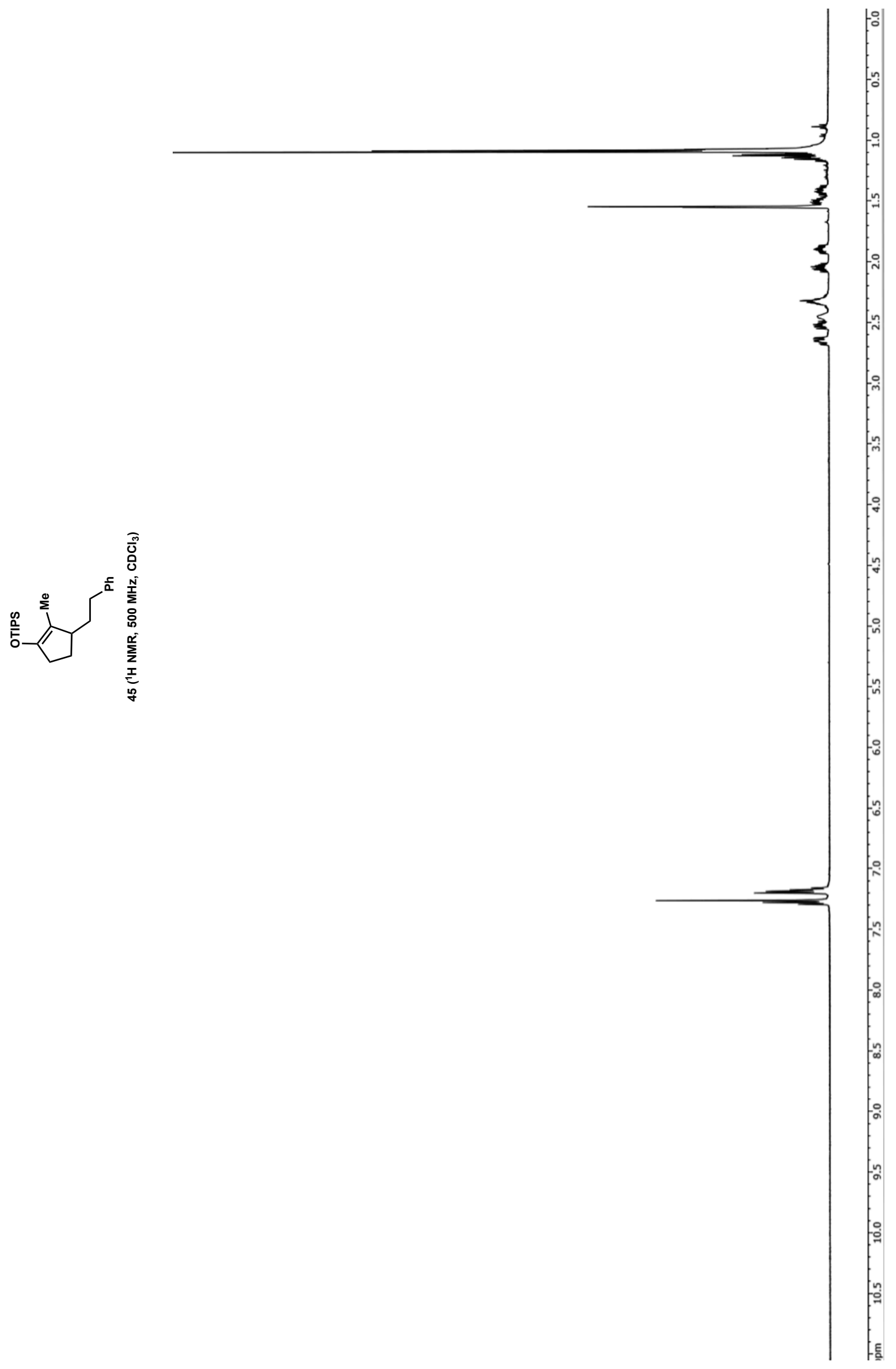



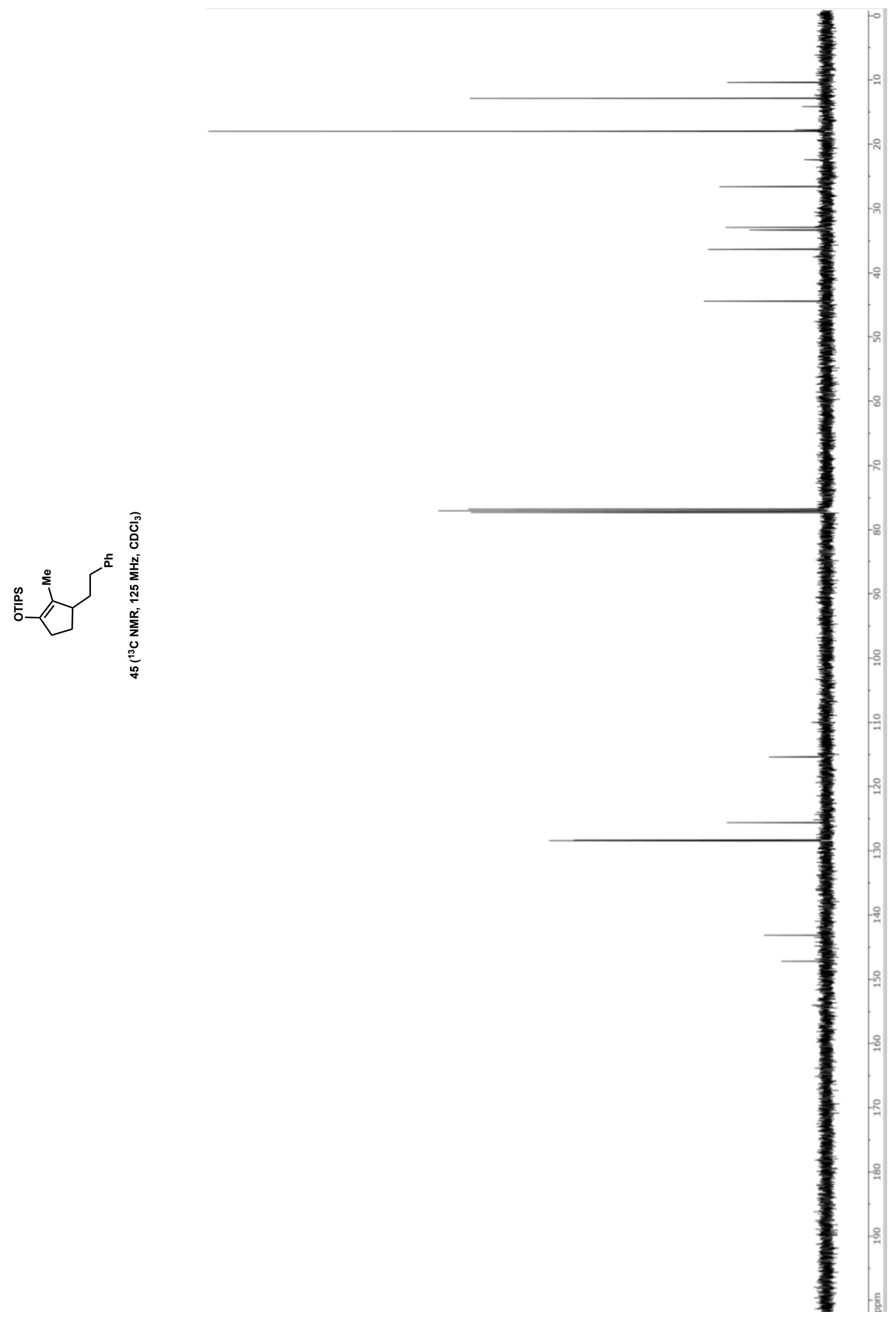


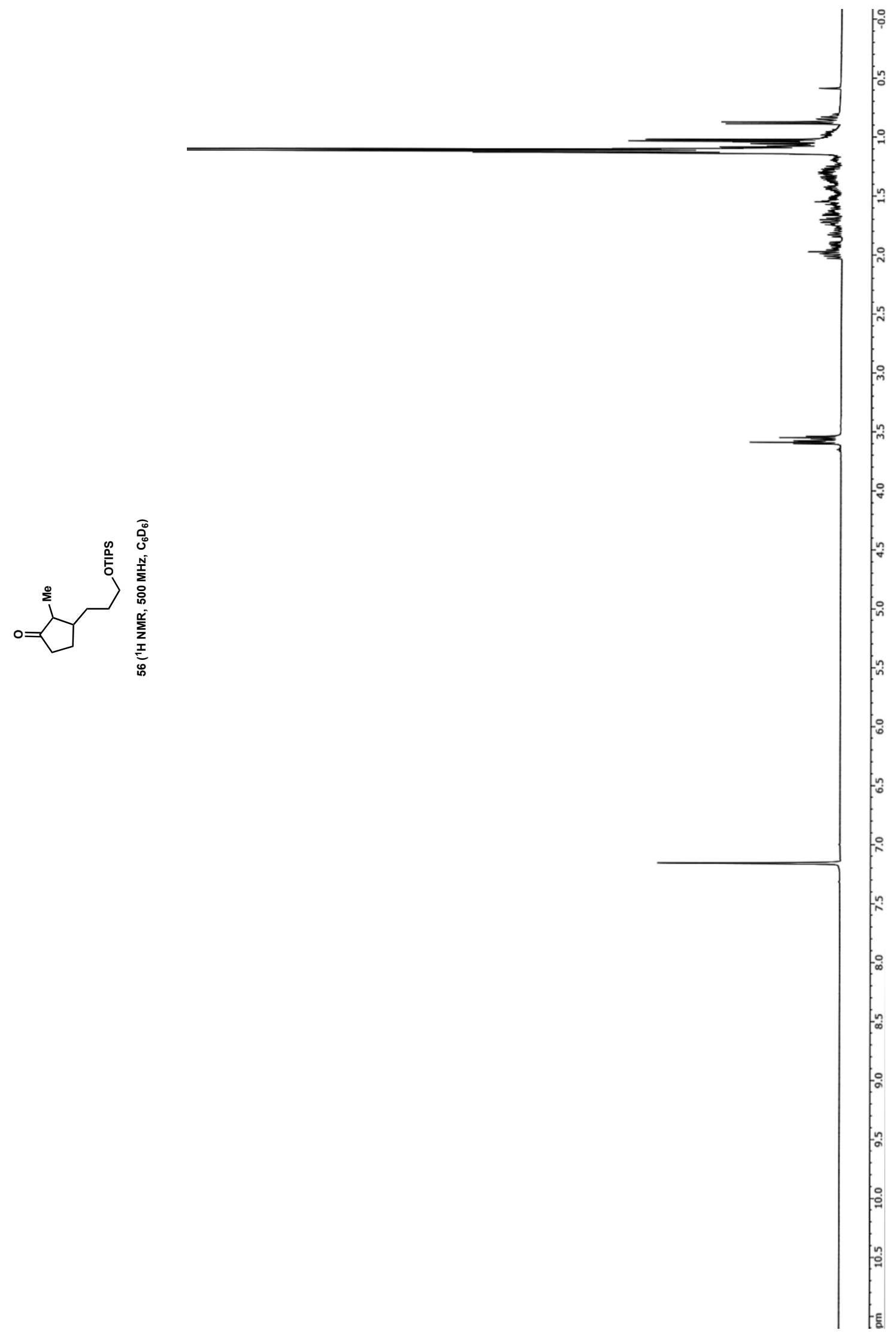




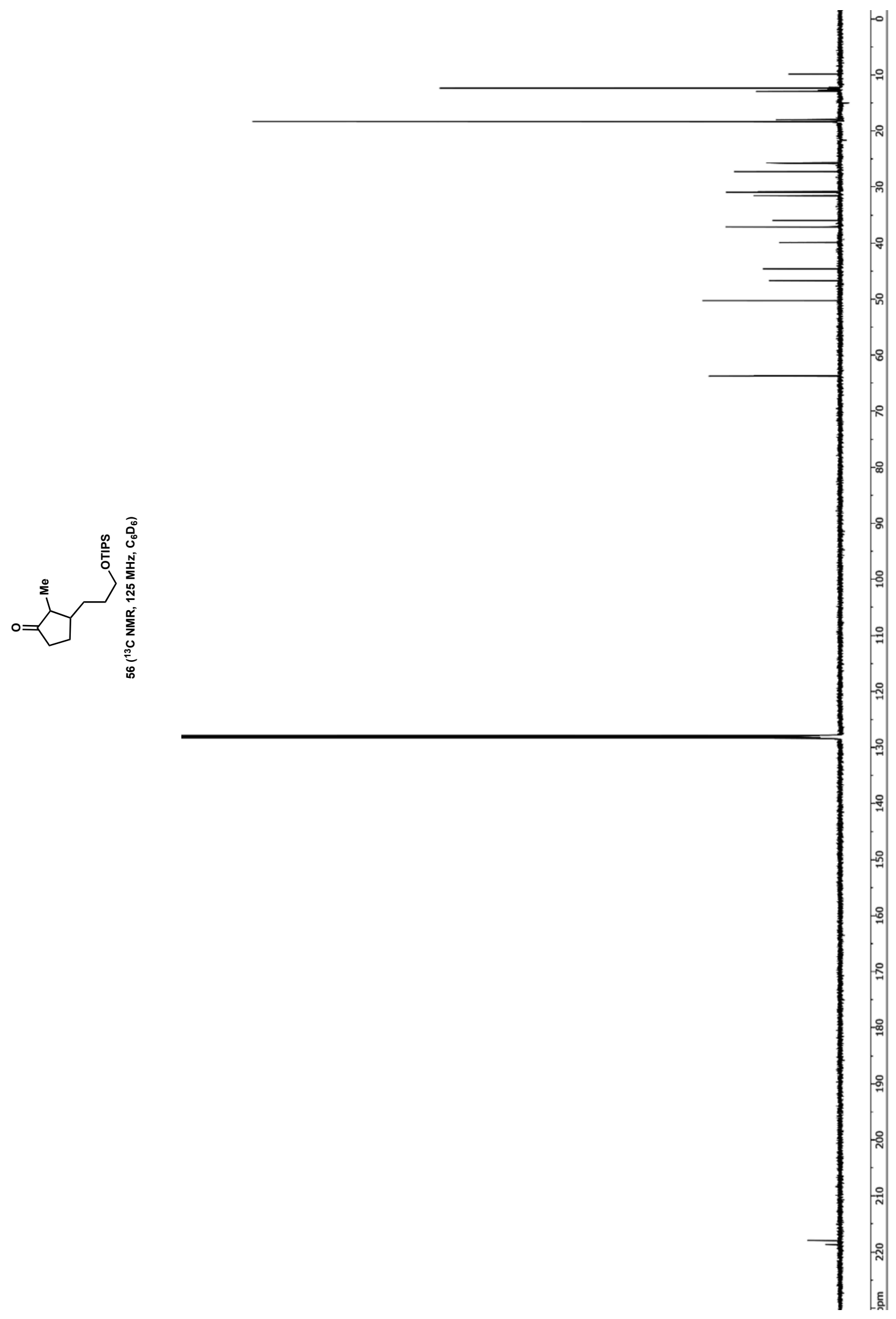




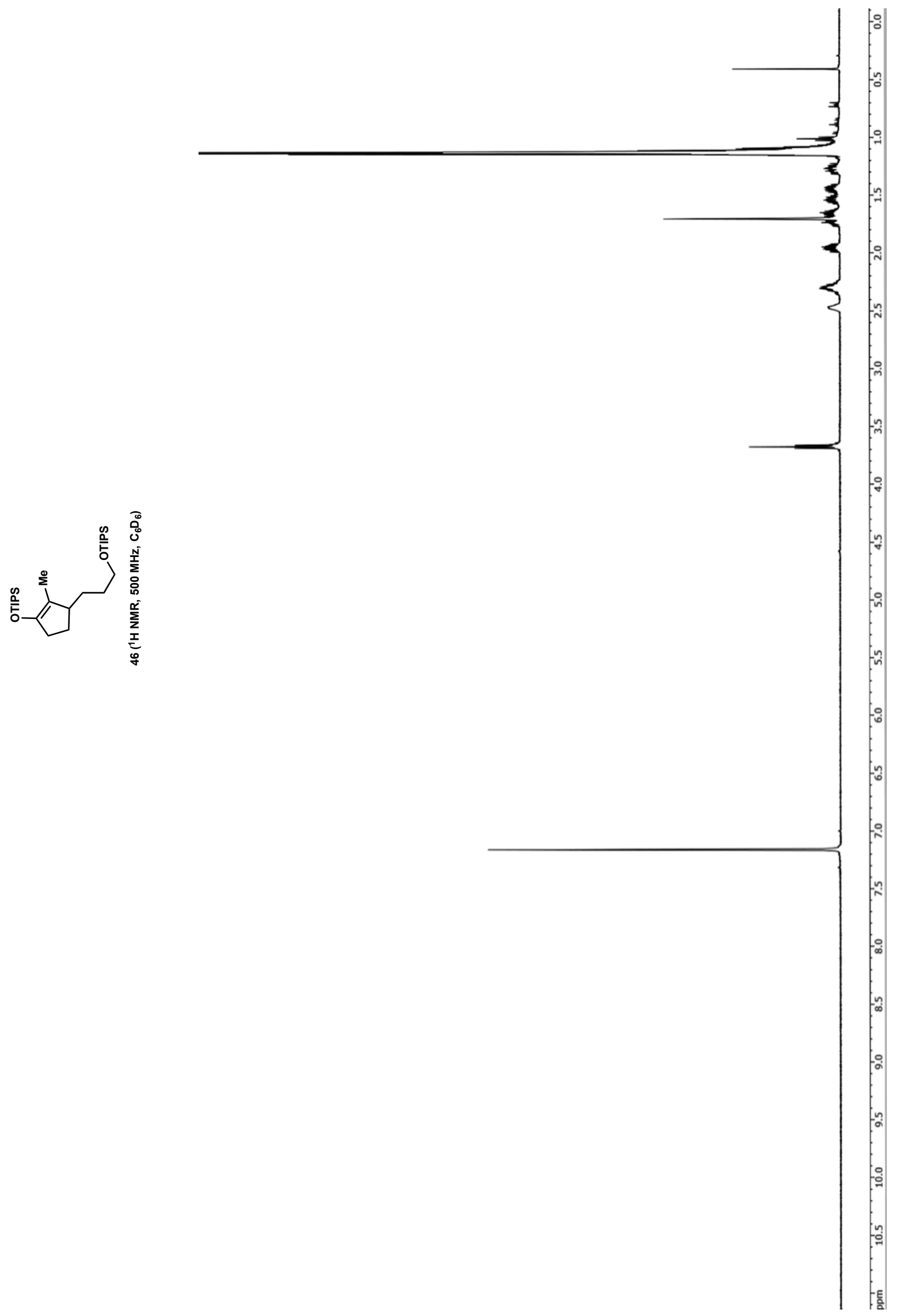




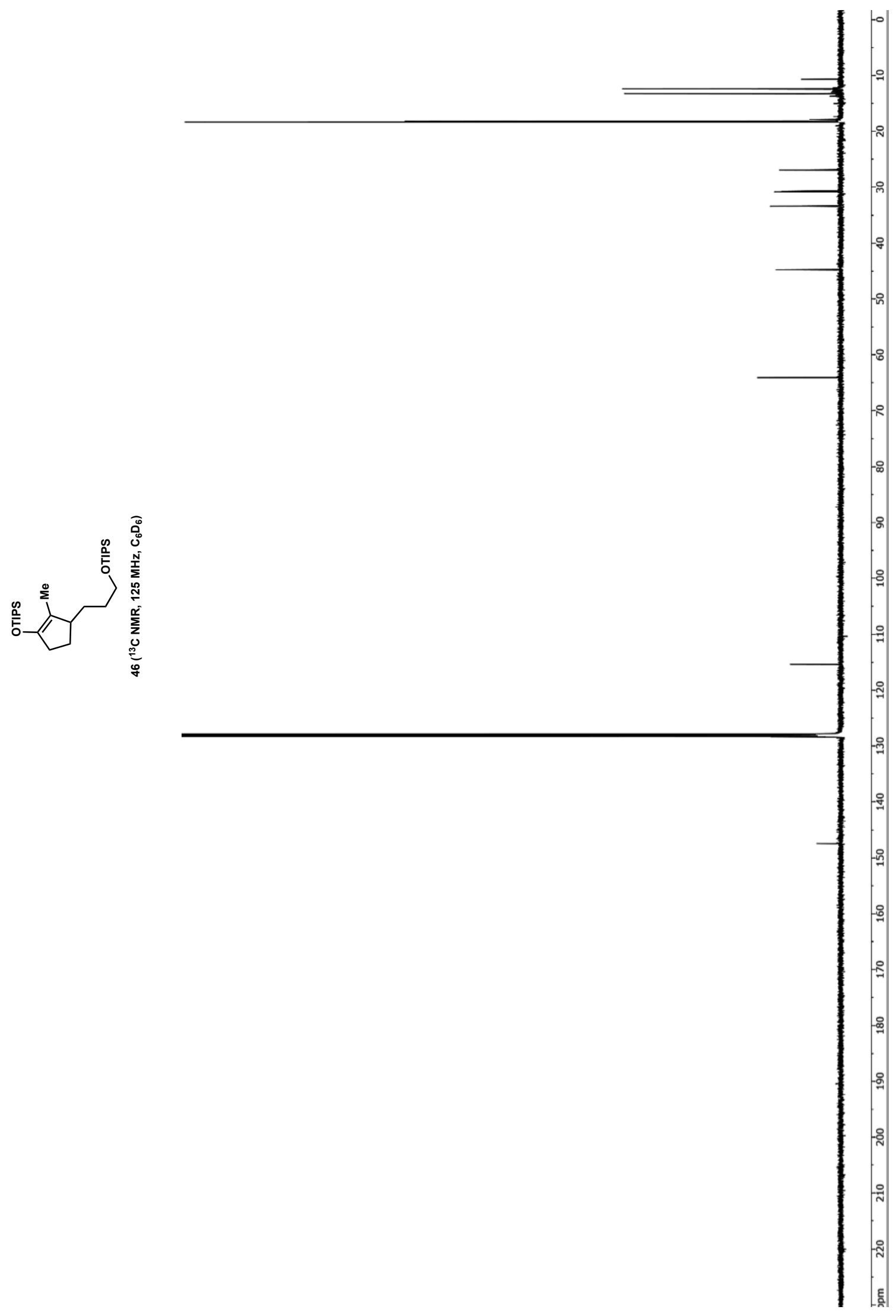




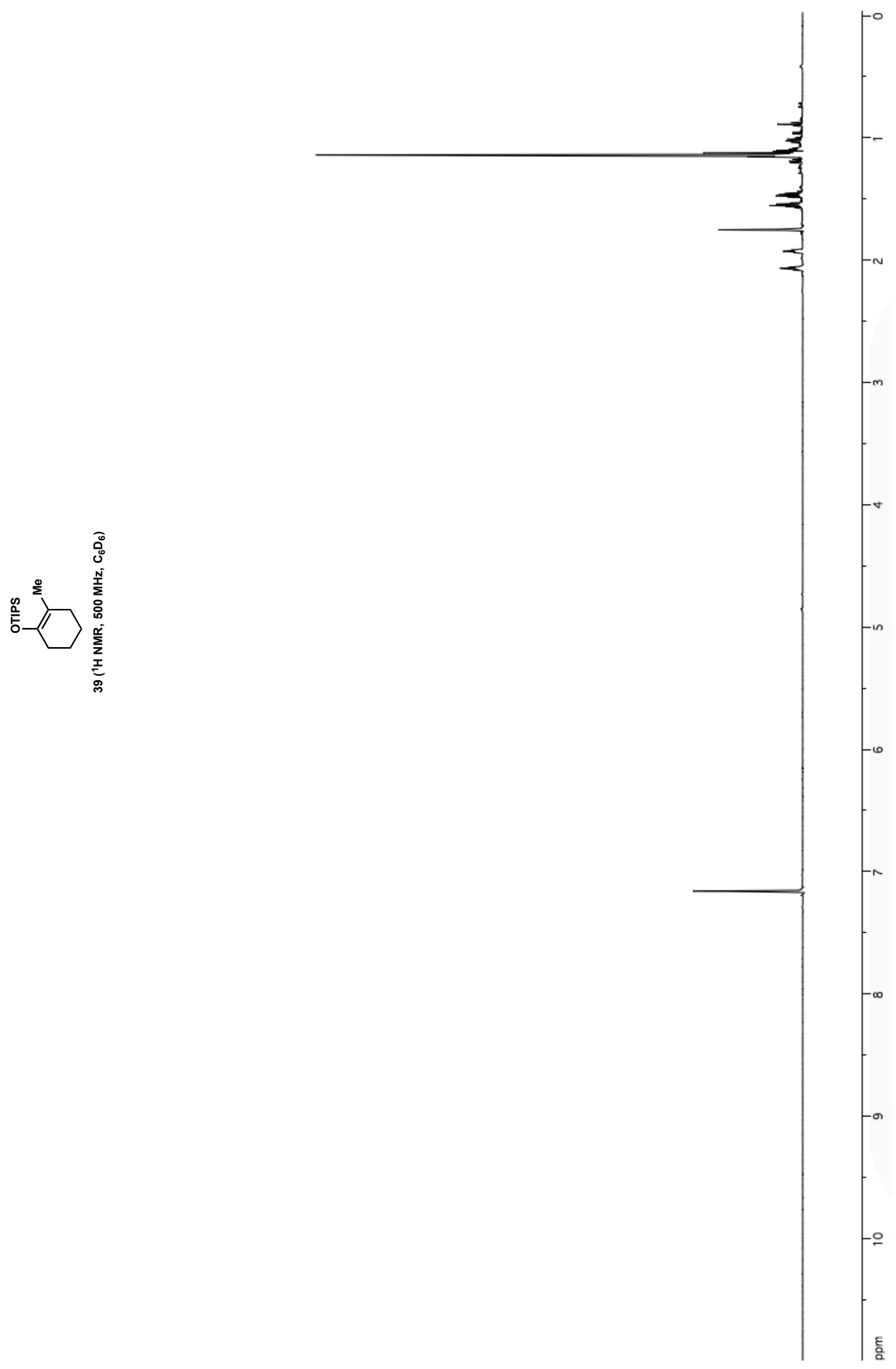




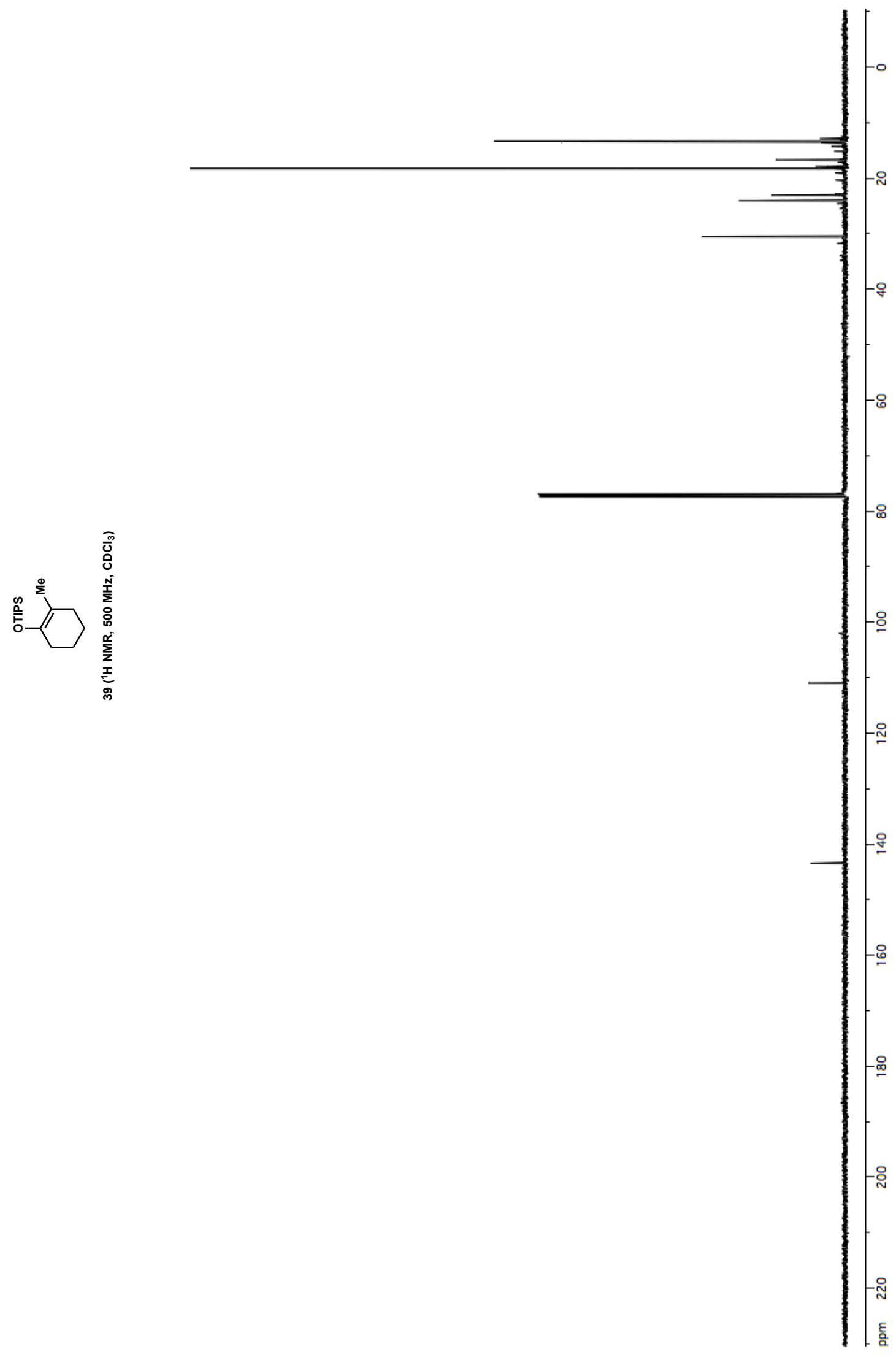




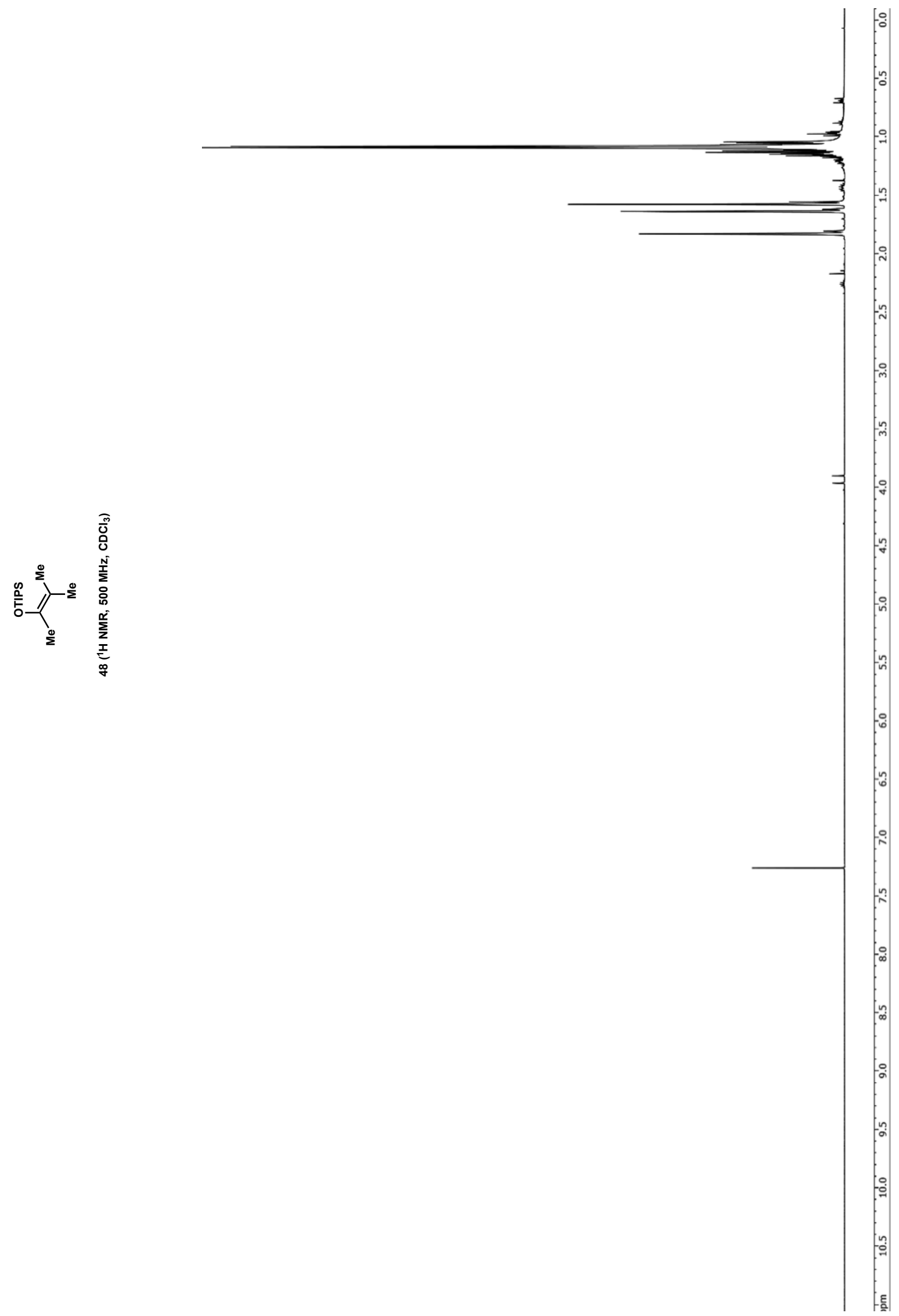




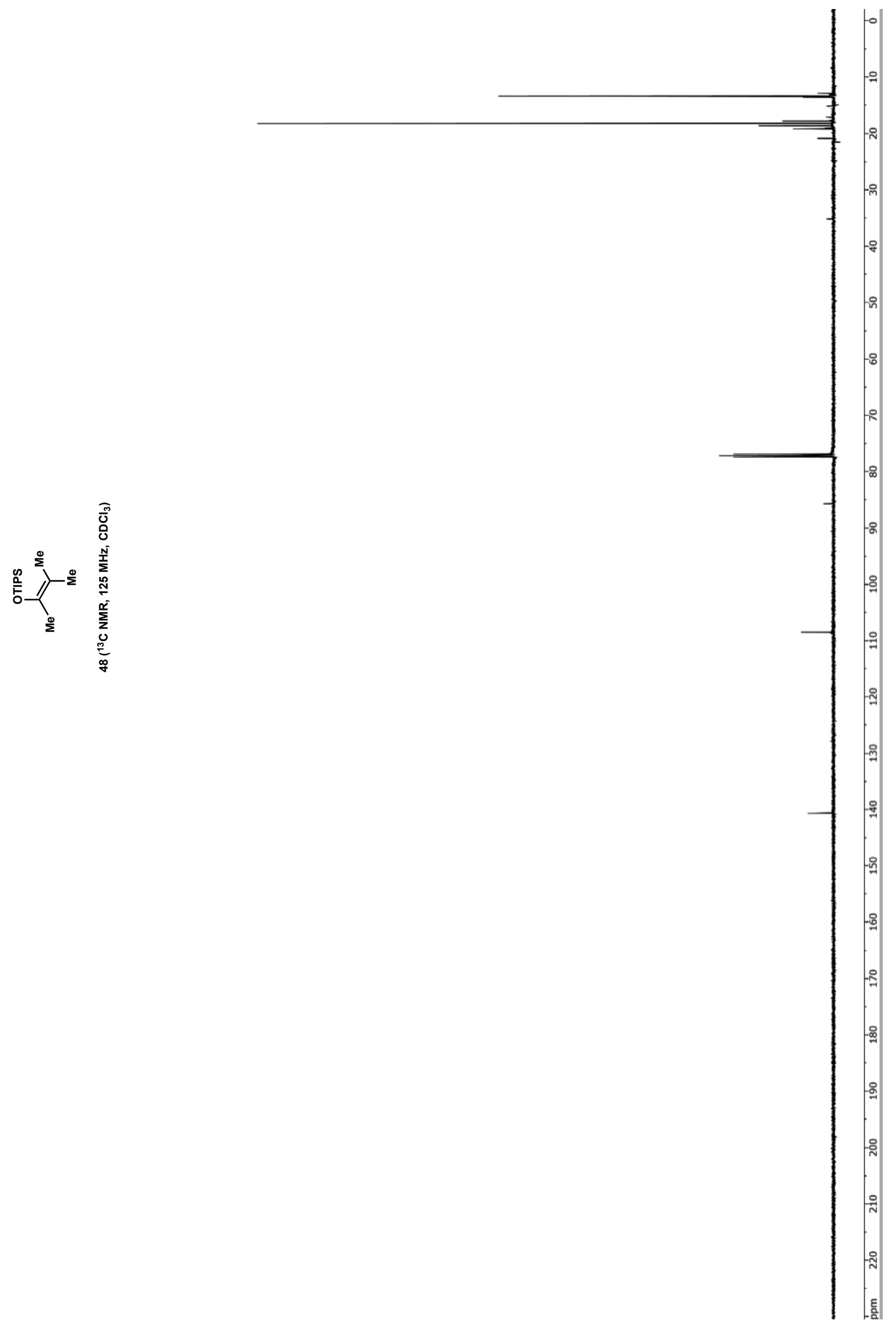




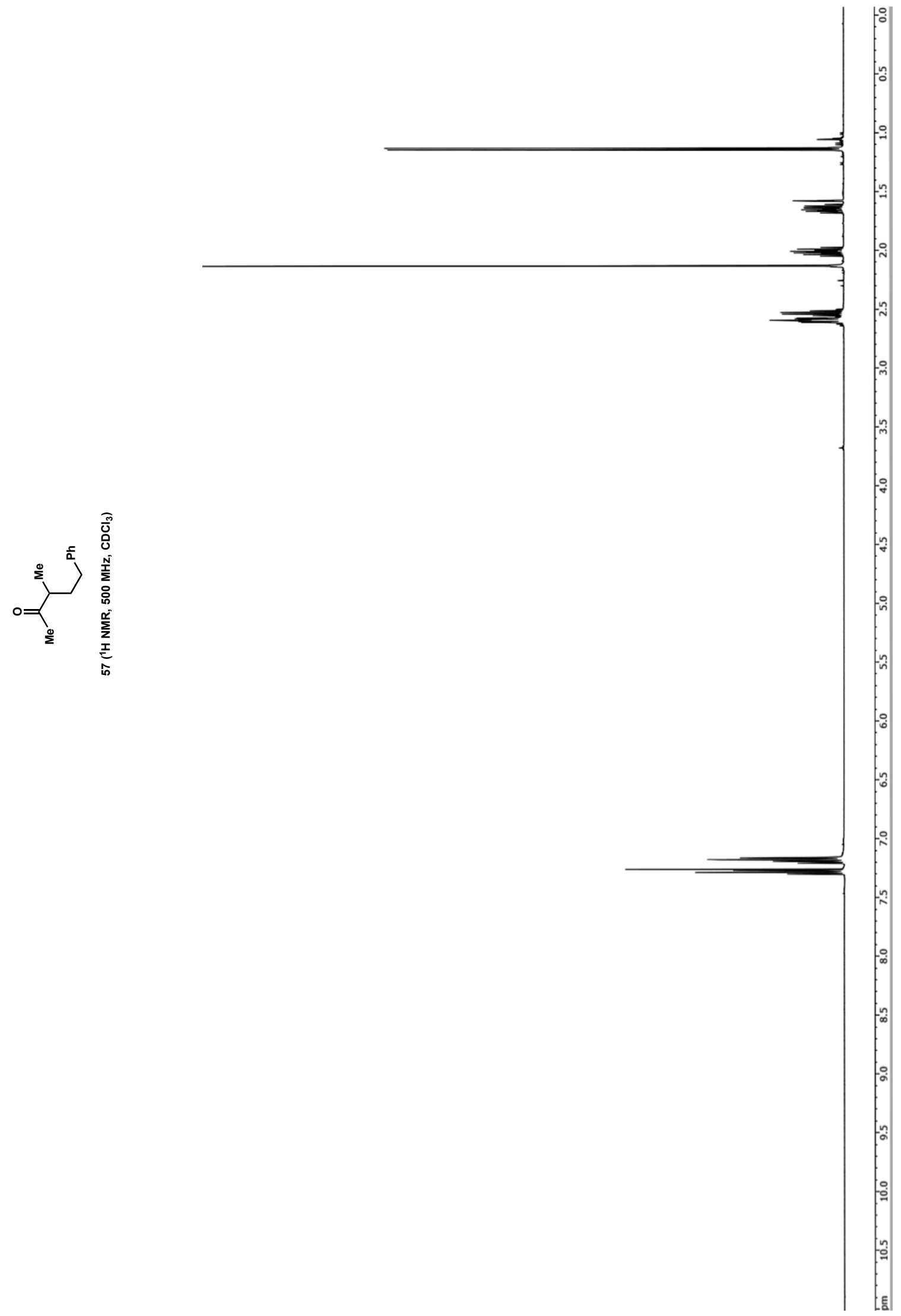

SI 141 


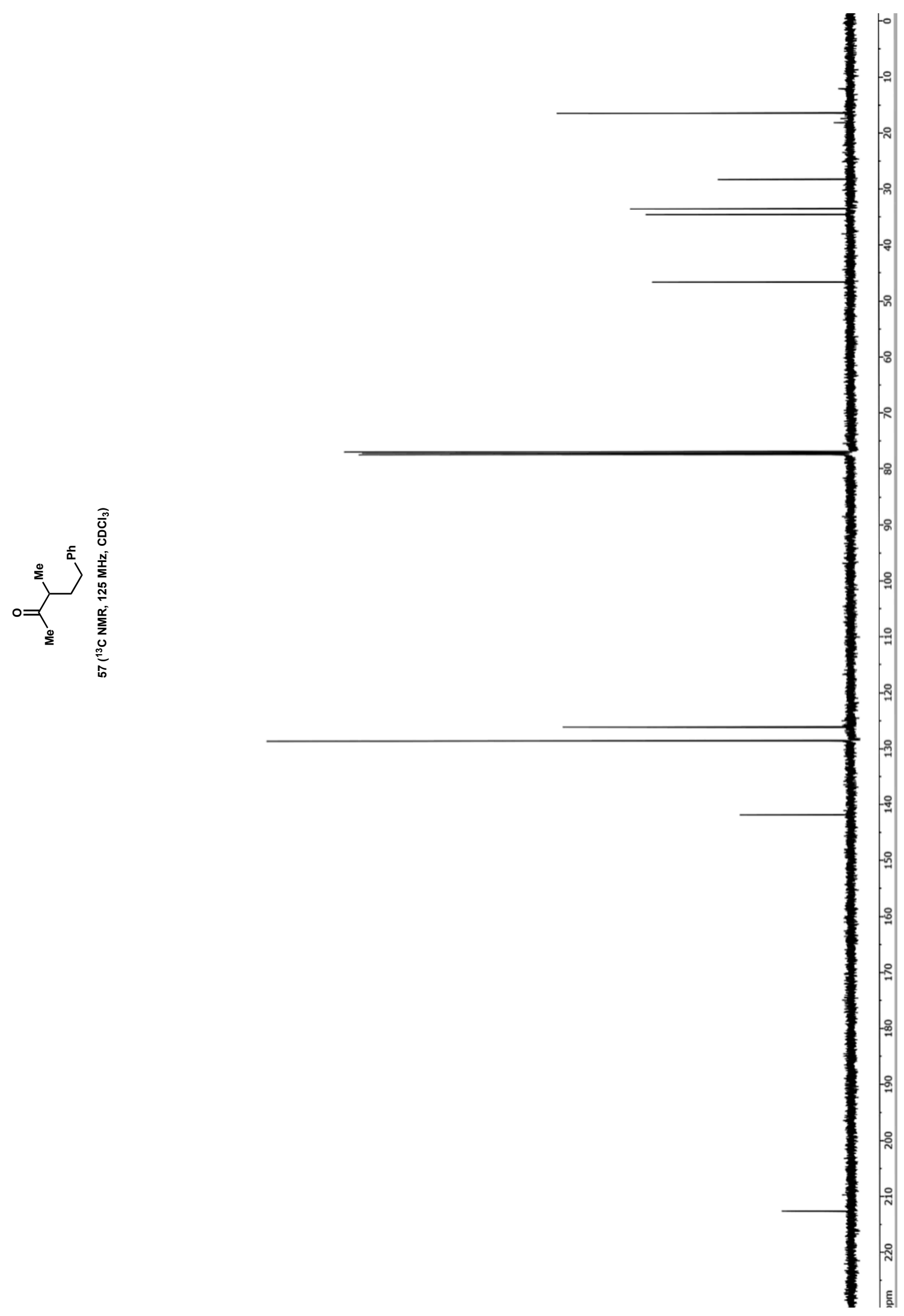




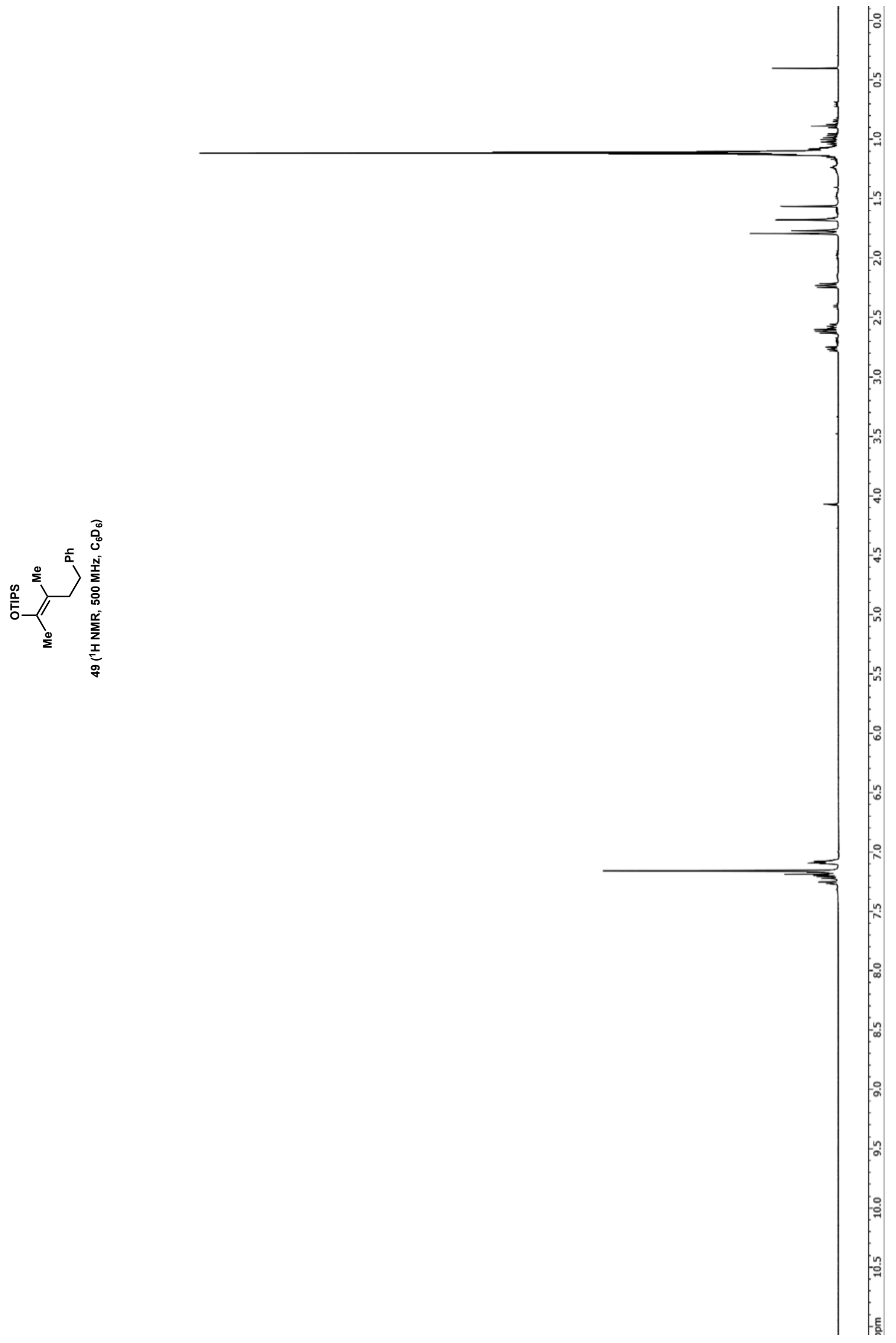




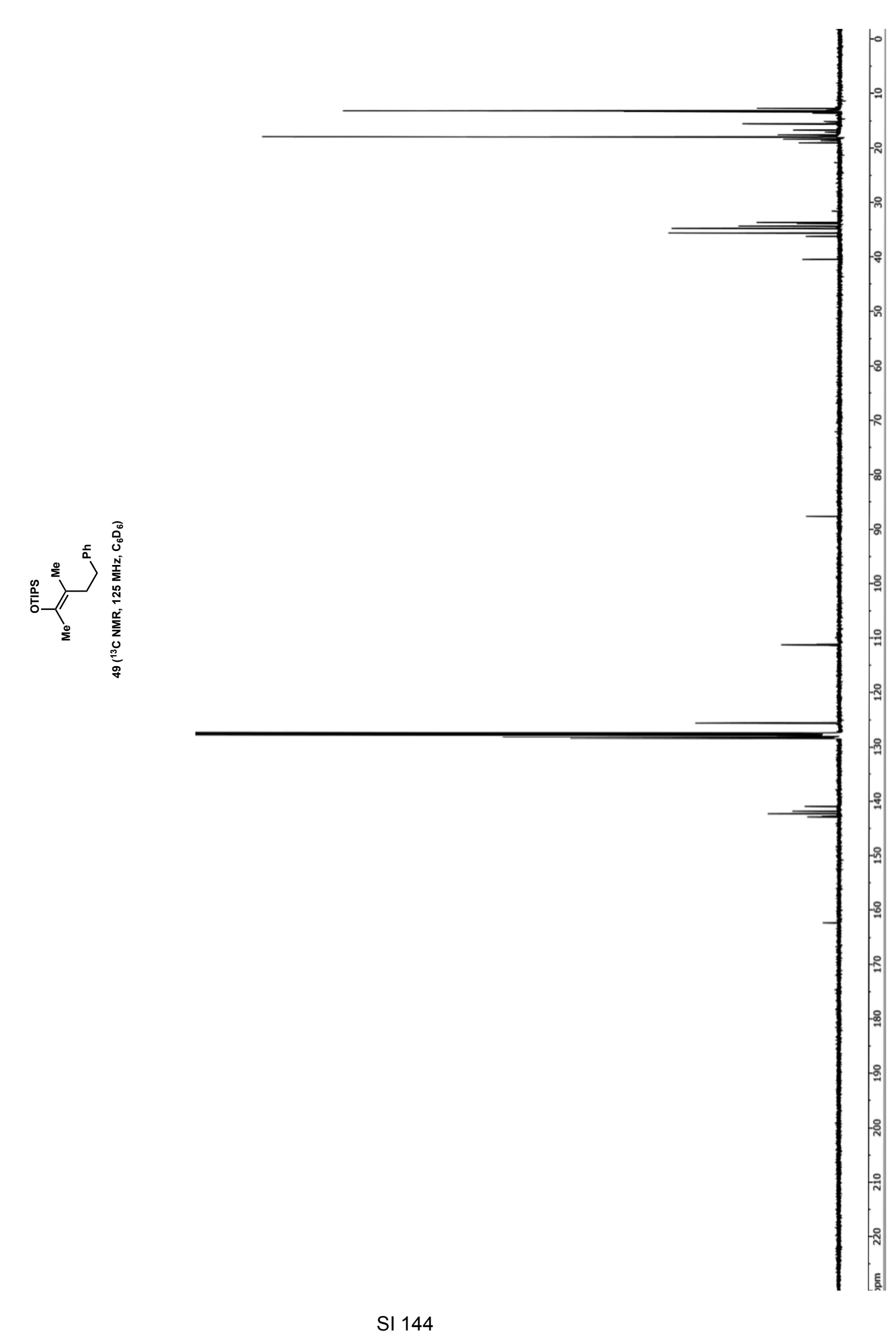




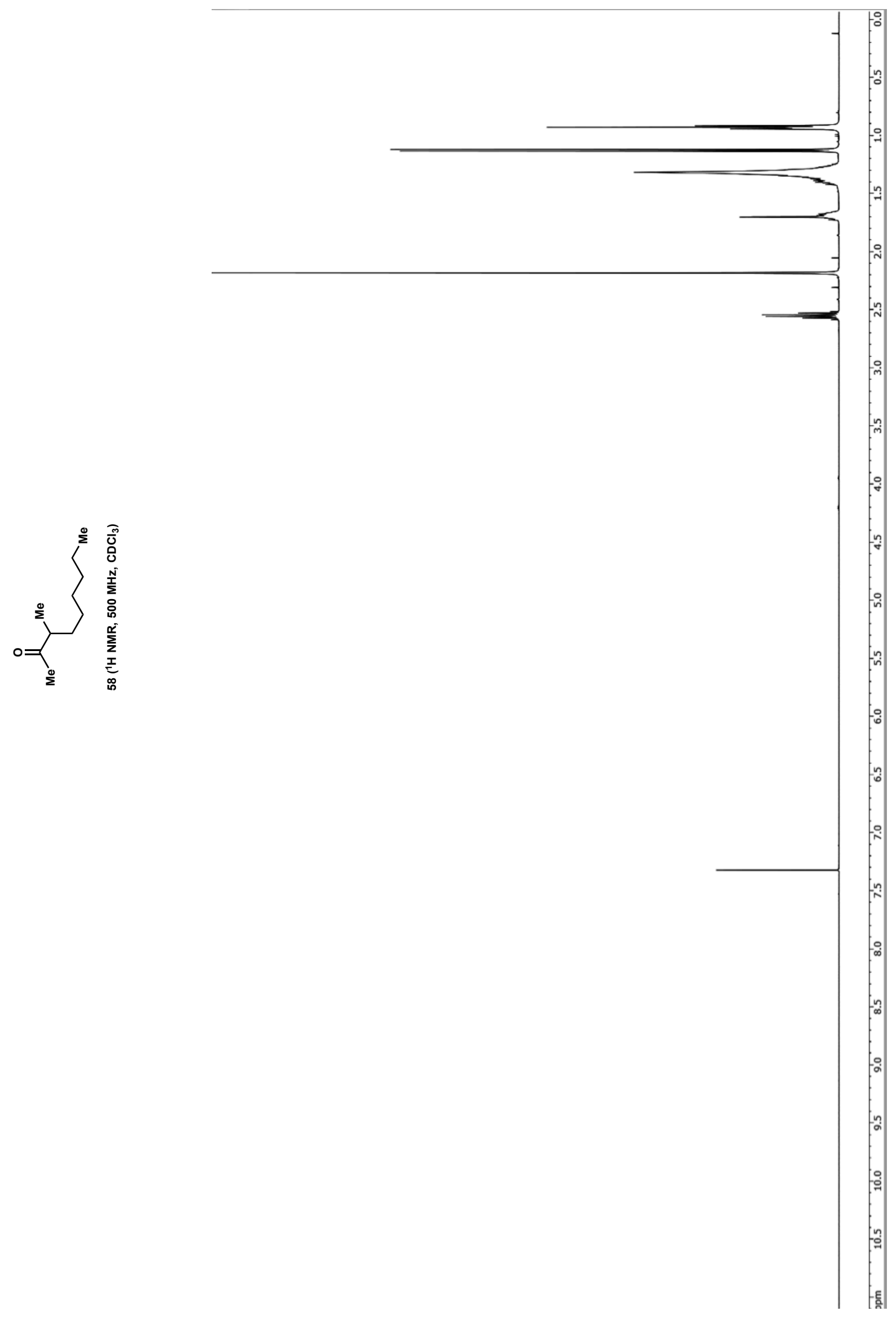




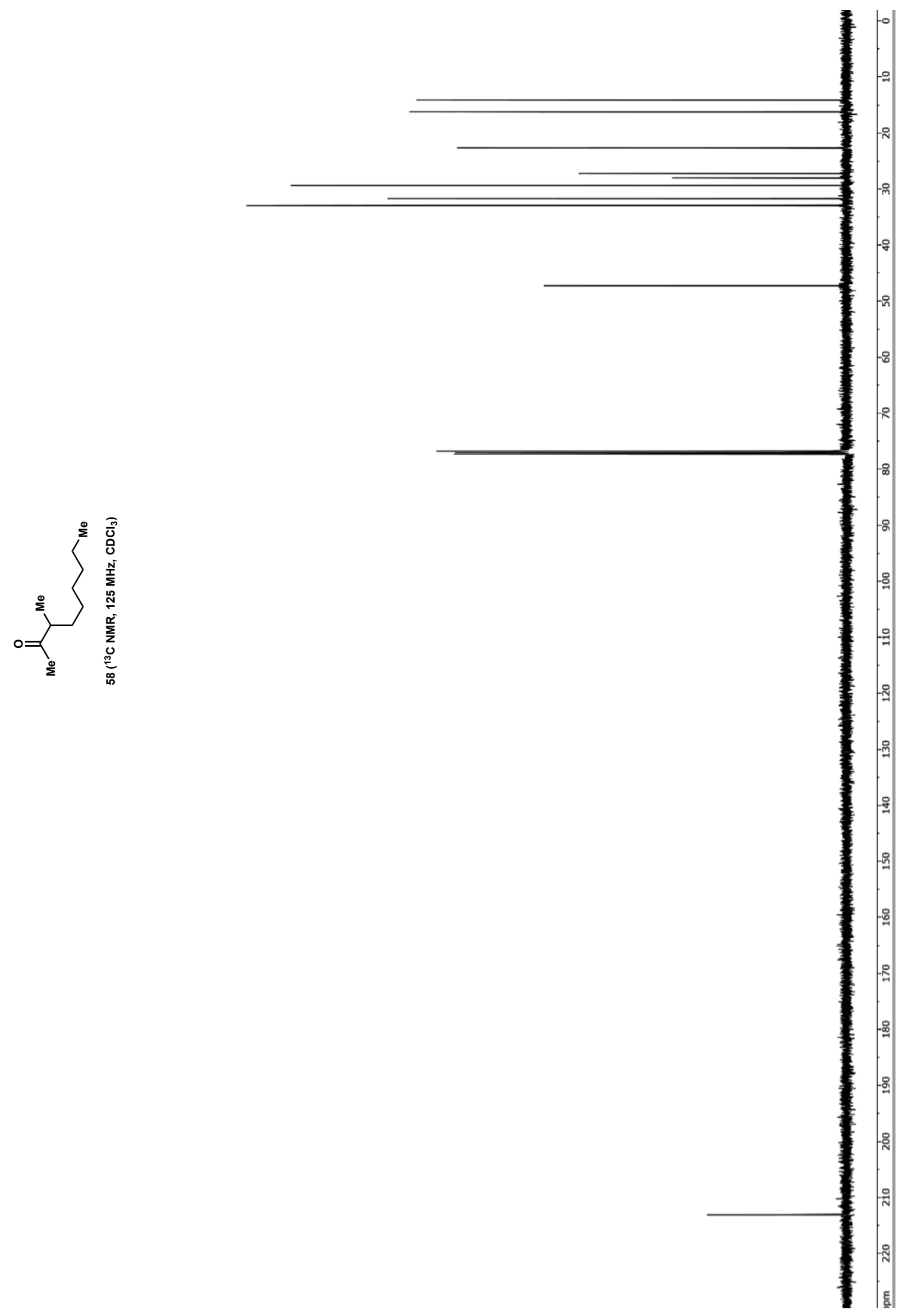

SI 146 


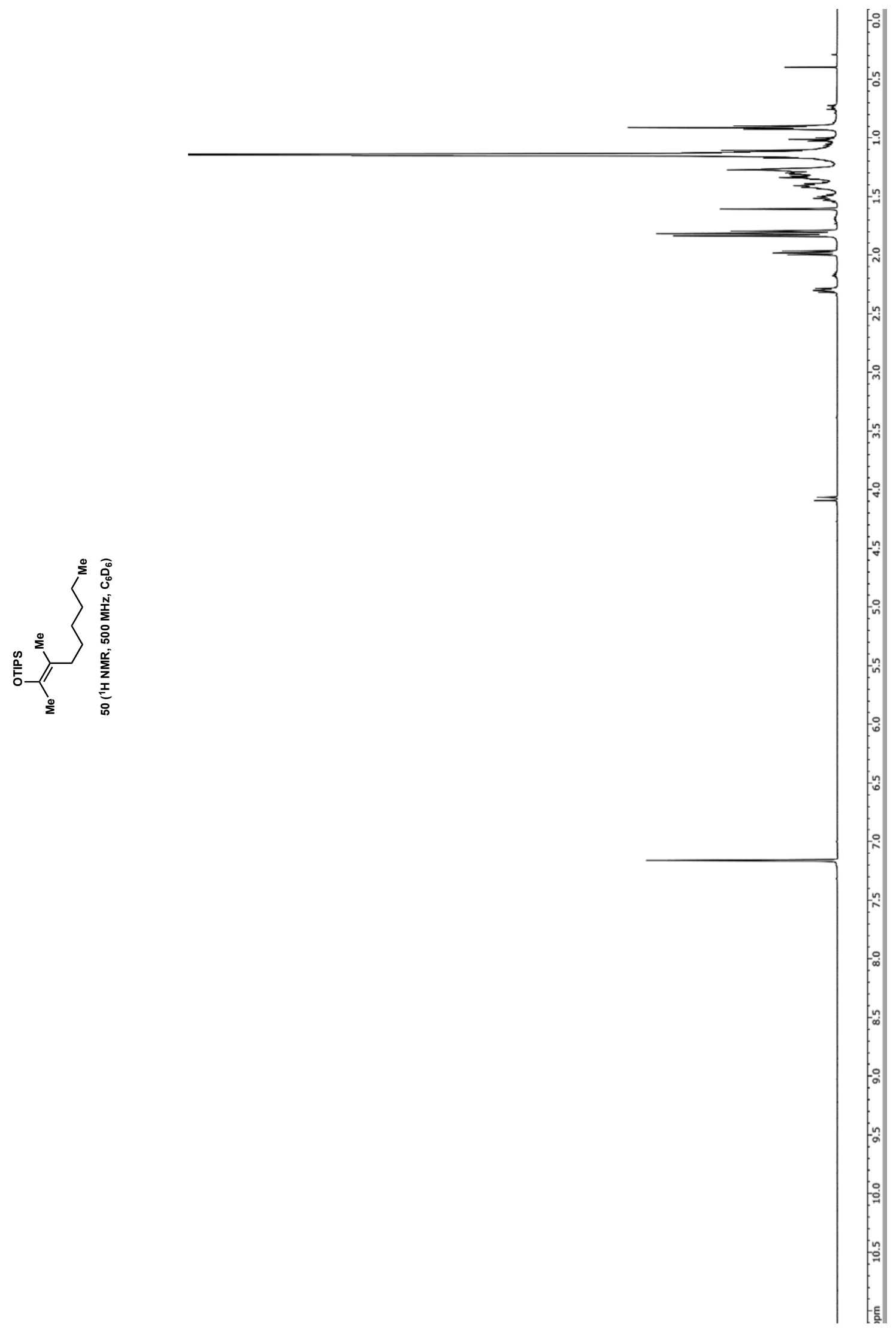




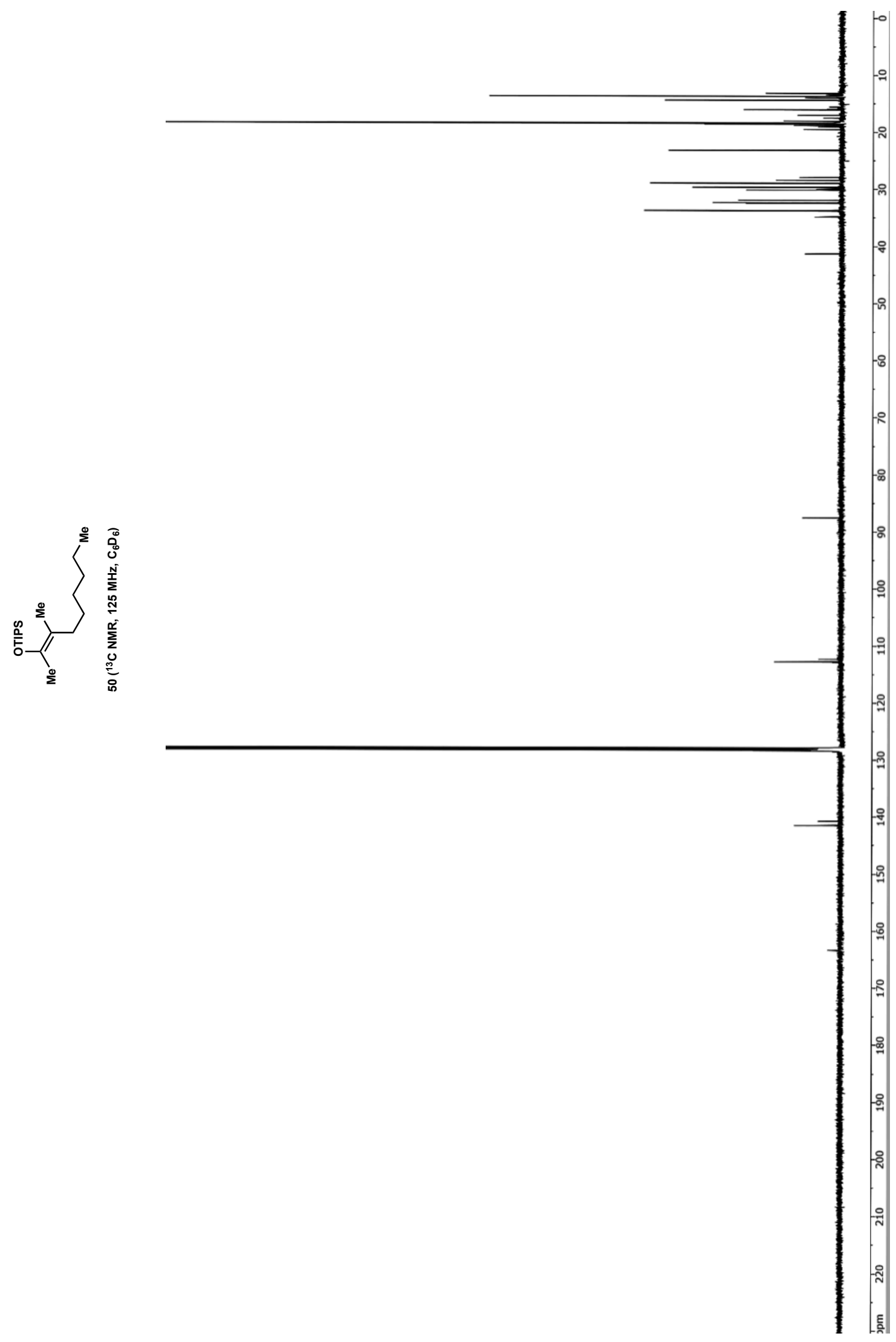




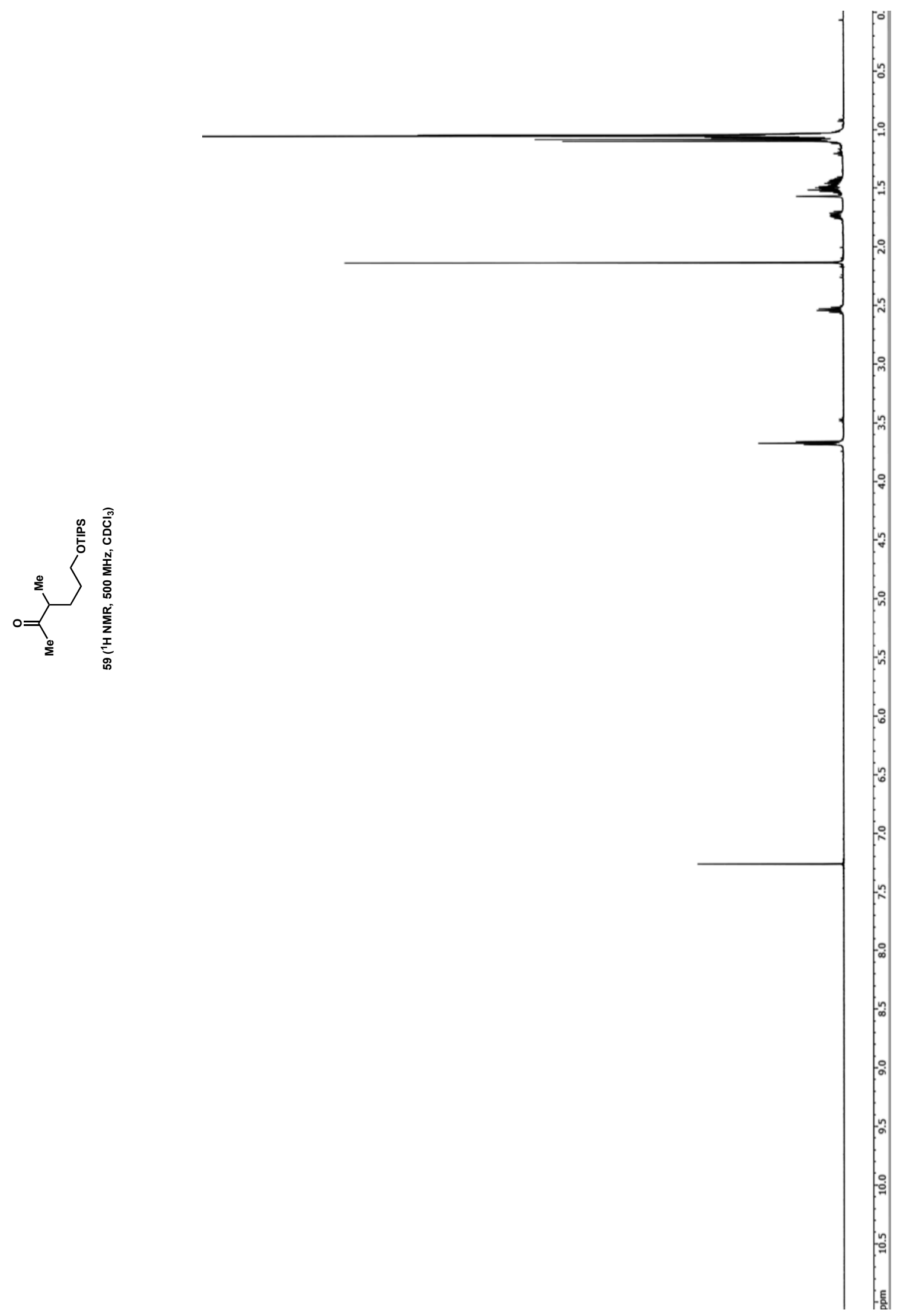




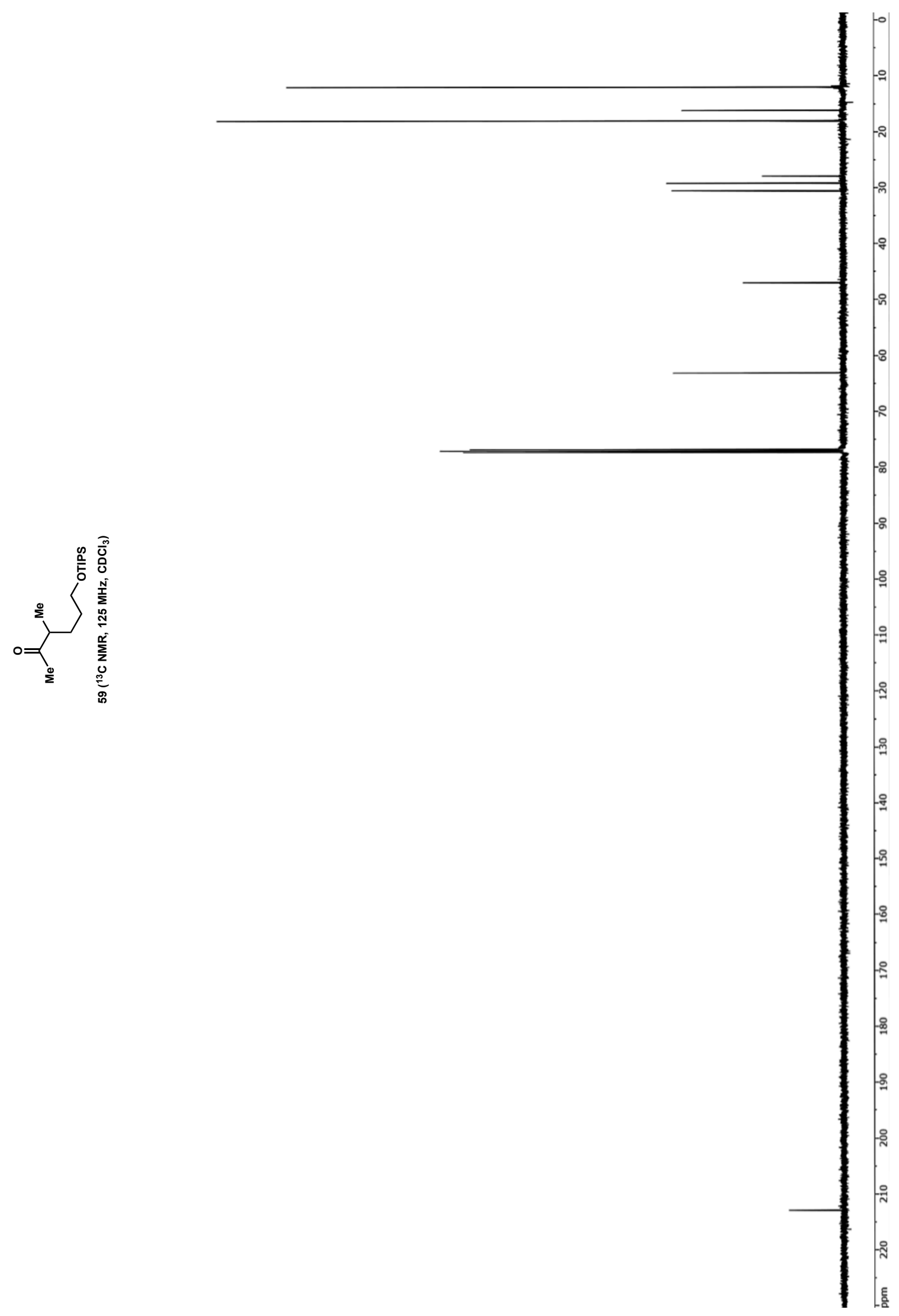

SI 150 


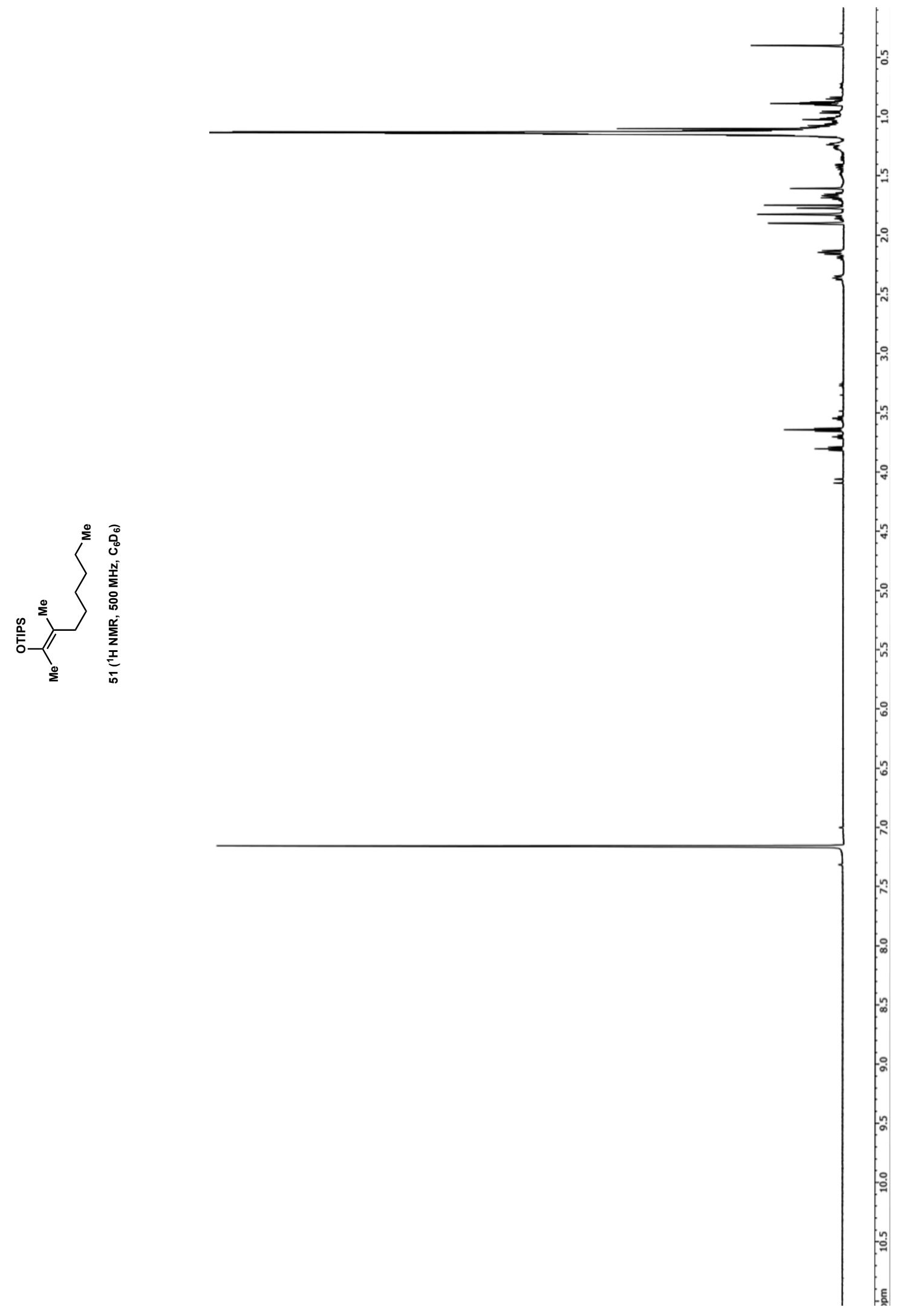




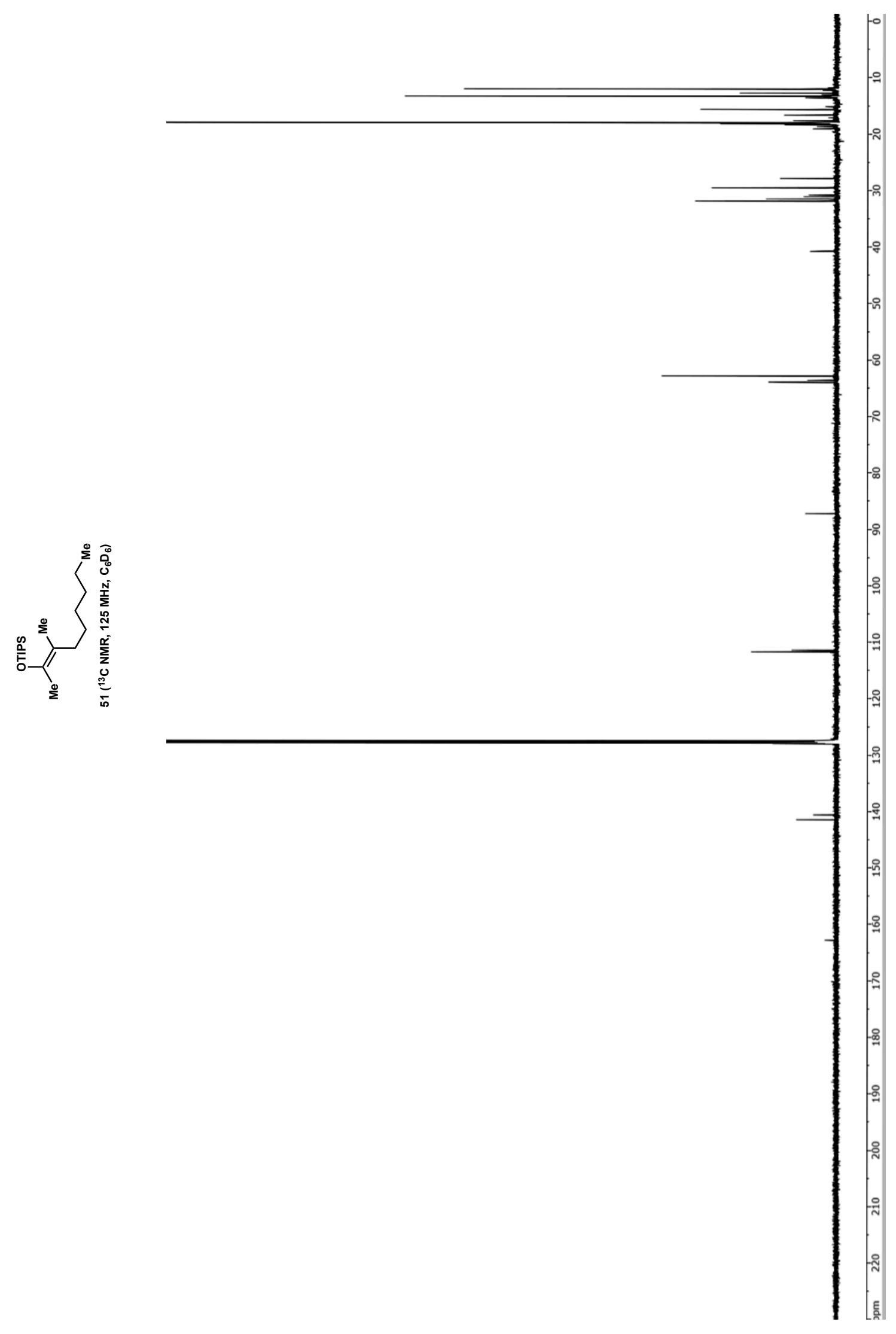

